University of Louisville ThinkIR: The University of Louisville's Institutional Repository

Electronic Theses and Dissertations

$5-2014$

\title{
Simulation model for optimization of a landside harbor logistic chain of container terminals.
}

Klaus Striegel

University of Louisville

Follow this and additional works at: https://ir.library.louisville.edu/etd

Part of the Industrial Engineering Commons

\section{Recommended Citation}

Striegel, Klaus, "Simulation model for optimization of a landside harbor logistic chain of container terminals." (2014). Electronic Theses and Dissertations. Paper 2268.

https://doi.org/10.18297/etd/2268

This Doctoral Dissertation is brought to you for free and open access by ThinkIR: The University of Louisville's Institutional Repository. It has been accepted for inclusion in Electronic Theses and Dissertations by an authorized administrator of ThinkIR: The University of Louisville's Institutional Repository. This title appears here courtesy of the author, who has retained all other copyrights. For more information, please contact thinkir@louisville.edu. 


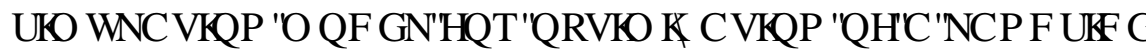

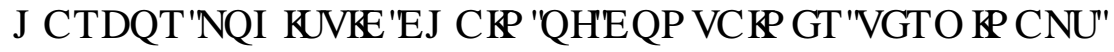

By

\title{
Klaus Striegel
}

Dipl.-Physiker, University of Stuttgart,1977

Betriebswirt (VWA), VWA Stuttgart,1985

\author{
A Dissertation \\ Submitted to the Faculty of the \\ - $\square \% \llbracket$ Speed Scientific School of the University of Louisville \\ in Partial Fulfillment of the Requirements \\ for the Degree of
}

\section{Doctor of Philosophy}

\author{
Department of Industrial Engineering \\ University of Louisville \\ Louisville, Kentucky
}

May[2014 
(C) Copyright 2013 by Klaus Striegel

All rights reserved 



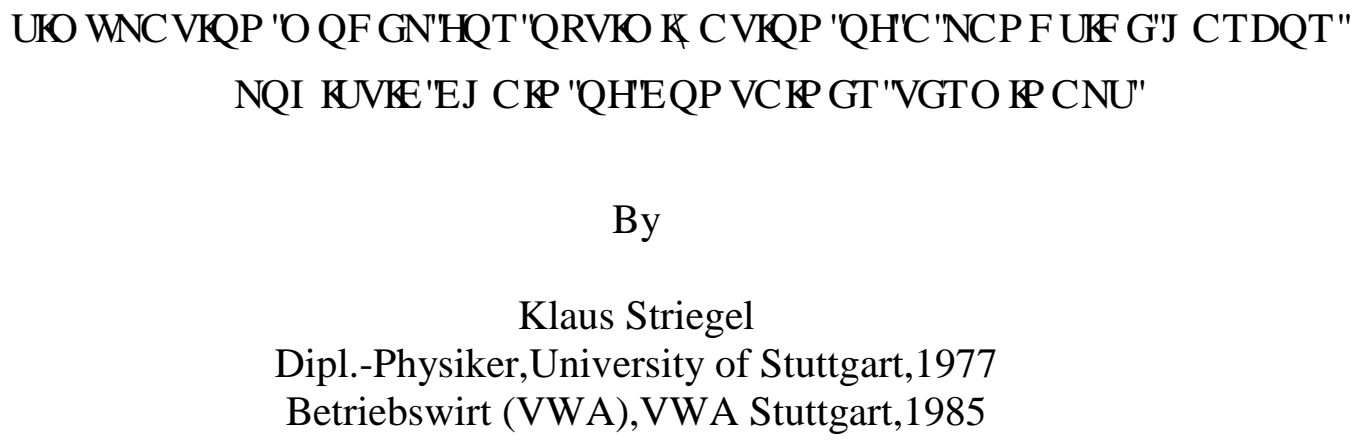

A Dissertation \$ SSLRYHGTRQ

December 3, 2013

by the following Dissertation Committee:

William E. Biles, Ph.D., P.E., Committee Chair

Gerald W. Evans, Ph.D.

Lihui Bai, Ph.D.

Thomas D. Rockaway, Ph.D., P.E. 
\$\&. $12: /\left({ }^{\prime} *(0)(176 \square\right.$

I offer my deepest gratitude to my supervisor and advisory, Dr. William E. Biles, whose interest, patience and instruction enabled this dissertation to be completed. During the entire research work he kindly granted me his support at any time. I would like to sincerely thank the other committee members Gerald W. Evans, Ph.D.Lihui Bai, Ph.D.and Thomas D. Rockaway, Ph.D., P.E, for their efforts in reviewing this research work. I acknowledge further the excellent support and advice by Prof. Dr.Carlos Jahn and Obering. Dr.Jürgen Böse from TU Hamburg-Harburg, Fraunhofer-Institute of Maritime Logistics. I would also like to thank the University of Louisville and all the Professors, who provided me the opportunity to pursue this research and further my education.

No acknowledgement would be complete without thanking my wife Sabine for her patience during my studies. 
\$ \% $675 \$ 870$

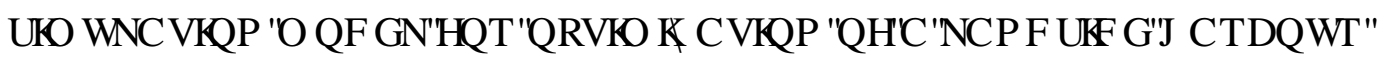 \\ / 2 * ,67, \& \& \& \$, 1 [2 ) I\&2 17 \$,1 ( $5 \square 7(50,1$ \$ / 6 \\ By \\ Klaus Striegel
}

December 3, 2013

The world wide transportation of all kind of goods with containers is a fast growing business. The challenge is to transport in the shortest time to the lowest cost. The vessels therefore become bigger and bigger. The biggest vessel with 16000 TEU is since December 2012 in service. But the next generation with 18000-22000 TEU is already being built. This raises questions in acceleration of loading and unloading process, the handling in the yards of the harbors and the transportation of the containers to Hinterland. The most common way is still to transport the container from the yard by truck, which causes a lot of traffic jams and pollution. With the growth of the volume and the limited space in most harbours the throughput in the yards must be dramaticly increased. One possibility is to reduce multiple handling of the containers and to decentralize the transport to Hinterland. The idea of Dryports emerged several years ago. In this research a simulation model of all processes in the logistic chain is designed, with which all steps are linked together. A direct flow of the containers without any intermediate stocking in the yard. Todays average staytime of the containers in the yard of 3-4 days is completely deleted. The multiple handling is avoided. The variability of all input figures and constraints allows that the most real situations can be considered. Three different 
modalsplits are run in simulation. The results show, that it is possible to reduce the throughput time of the containers and the overall loading and unloading process of vessels in the harbor and to gain a high productivity. With the satellite model ( Dryport ) it is possible to reduce traffic in the yard and to avoid a lot of pollution. Overall shorter service times give an answer to the challenge of managing the future growth of the container business. The feasibility of the proposed model is confirmed. 
ACKNOWLEDGMENTS $\quad$ iii

ABSTRACT

LIST OF TABLES

LIST OF FIGURES

CHAPTER 1 INTRODUCTION 1

1.1. Market issues 1

1.1.1. Container fleet and future outlook 2

1.1.2. Harbor situation 4

$\begin{array}{ll}\text { 1.1.3. Freight cost situation } & 8\end{array}$

$\begin{array}{ll}\text { 1.1.4. Market conclusion } & 10\end{array}$

$\begin{array}{ll}\text { 1.2 Current status in container logistics } & 12\end{array}$

1.2.1. Existing logistic processes in container transportation chain 12

1.2.2. Existing logistic process in the harbor 15

1.2.3. Targets and guide lines for inprovements in the $\begin{array}{ll}\text { container logistic chain } & 17\end{array}$

1.2. Research Objective 19

CHAPTER 2 LITERATURE REVIEW 20

2.1. General review 20

$\begin{array}{ll}\text { 2.2. Dryports } & 25\end{array}$

2.3. Container Terminal and yard services 32 
3.1. Elements of the Model 35

3.1.1. Bill of loading in coming containers 36

$\begin{array}{ll}\text { 3.1.2. Quay crane } & 40\end{array}$

3.1.3. Yard transportation system $\quad 40$

3.1.4. Transportation system to satellites 42

3.1.5. The Satellite 42

3.1.6. Train Railway station 43

3.1.7. Feeder 44

3.1.8. Bill of Loading Export 47

3.2. Flow chart of the logistic chain from the containership to Hinterland 48

3.2.1. Flow chart harbor 48

3.2.2. Flow chart Satellite 49

3.2.3. Flow chart train 51

3.3. Scope of the Model 52

3.4. The proposed model 54

3.4.1. Major equipment elements in the model 54

3.4.2. Model tree $\quad 55$

3.4.3. Overviw about the model with major areas 56

3.4.4. Examples of programming,controlling reporting 60

$\begin{array}{ll}\text { CHAPTER } 4 \text { MODEL EXPERIMENTATION } & 68\end{array}$

4.1. Basic Model 68

$\begin{array}{ll}\text { 4.1.1. Input values } & 68\end{array}$ 
4.1.3. Modifications of the basic model 72

4.1.4. Comments to the modal split 73

4.2. Experimental results $\quad 75$

4.2.1. Basic model 75

4.2.2. Comments to the basic model 90

4.2.3. Results of the modifications of the basic model 91

4.3. Technical feasibility of the transport systems 108

4.3.1. Unloading-Loading Process in the Yard or at trainstation or

$\begin{array}{ll}\text { Dryport terminal } & 108\end{array}$

4.3.2. Transport System to train station, satellites and feeder loading area 112

$\begin{array}{ll}\text { 4.3.3. Crane Systems } & 115\end{array}$

4.4. Economic analysis - infrastructure and running cost 117

$\begin{array}{lll}\text { 4.4.1 Infrastructure } & 117\end{array}$

$\begin{array}{lr}\text { 4.4.2. Running Cost } & 120\end{array}$

4.5. Environmental analysis and impact to pollution 135

CHAPTER 5. SUMMARY, CONCLUSIONS AND RECOMMENDATION 140

$\begin{array}{lr}\text { REFERENCES } & 150\end{array}$

$\begin{array}{ll}\text { APPENDIX . Abbreviations } & 160\end{array}$

$\begin{array}{ll}\text { CURRICULUM VITAE } & 161\end{array}$ 


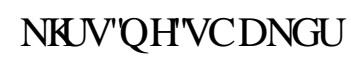

TABLE

PAGE

1. Existing fleet ( different seizes ) and ordered vessels 3

2. Planned container capacities of harbors 4

3. Overview of some selected existing or planned automated container terminals 4

4. Harpex rates related to the vessel seize 10

5. Benefits for actors of the system Dryport 27

6. Overview of existing Dryports and range of offered services 31

7. Overview about the chosen modal split 75

8. Results of the basic model 77

9. Overview about the modifications 107

10. Cost of staytime in the harbor for 24 hours 128

11. Terminal handling cost of different harbors 132

12. Comparison of traditional harbors with the model 146 


$$
/, 67[2) \square), * 85(6 \square
$$

FIGURE

1 IHS prognostics for growth of the world economy 1

2 IHS prognostics of world container transport 2

3 Typical layout of a container terminal 5

4 Throughput Density TEU/hectare $\quad 6$

5 Daily traffic jam in the harbor of Hamburg 7

6 Harpex Index of sea-freight rates 9

7 Cost-structure of seatransport and Hinterlandtransport 11

8 Main routes of containers with TEU distribution 13

9 Staytime of containers in the yard Auckland / NZ 14

10 ZPMC Automated Container Yard Stacking System with $\begin{array}{ll}\text { automated Tandem or Triple QC } & 17\end{array}$

11 The container logistic chain $\quad 21$

12 Pollution of different carriers 23

13 Pollution of different sectors $\quad 24$

14 The Dryport concept 26

15 Basic idea of the layout for the model 35

16 Bill of Loading 37

17 Example of parallel loading/unloading process between vessel and feeder 45

18 Example of loading/unloading process of a feeder serving 2 vessels 46

19 Bill of Loading for export 47 
20 Flow chart container from vessel to caroussel exits

21 Flow chart satellite-truck loading

22 Flow chart train loading

23 Model tree

24 Overview of the model layout with vessel,QC,carrousel distribution nodes for feeder,satellites, train

25 Simulation model with all connections of the elements

26 Model for the yard with QC and carrousel

27 Model of the train loading area

28 Model of the satellite with truck loading area

29 Example atom server crane 8 general

30 Example atom server crane 8 specific

31 Example atom visualization

32 Example for status monitor

33 Example for tracer

34 Status monitor of the 3 cranes loading the trains

35 List of train departure times at each track

36 Example of a part of the summary report

37 Distribution of departure of ship 1

38 Difference of train departures during one run

39 Status monitor for the TC in basic model

40 Status monitor for the train caroussel

41 Example for the distribution of TPT railtrack 1 - 2 ( long distance ) 
42 Example for distribution of TPT railtrack 3 - 5

43 Example for SM administration and SM satellite 1 85

44 The SM docking station truck 86

45 Example for distribution TPT truck loading direct 87

46 Example for distribution TPT truck loading indirect 88

$47 \mathrm{SM}$ for the $\mathrm{YCa} \quad 89$

$48 \mathrm{SM}$ for administration and SM satellite $1 \quad 94$

$49 \mathrm{SM}$ of administration and SM satellite 1 basic model 95

50 TPT distribution for containers to satellite 1 truck loading 97

51 Complete blockage at train station in modalsplit $2 \quad 100$

52 TPT for containers to railtrack 1 - 2 in modalsplit 2

53 TPT for containers to railtrack 3 - 5 in modalsplit $2 \quad 102$

54 TPT for railtrack 1 - 2 in modalsplit $3 \quad 103$

55 TPT for railtrack 3 - 5 in modalsplit $3 \quad 104$

56 Train departure times in modalsplit $3 \quad 105$

$57 \mathrm{SM}$ for the TC show a low utilization in modalsplit $3 \quad 106$

58 Handling with electric monorail CONCAR 109

59 Illustration of the material flows in a rail to rail hub for a transtainer $\begin{array}{ll}\text { Terminal and } 6 \text { parallel monorails } & 110\end{array}$

60 Simplified layout of a CONCAR terminal for regular service trains $\quad 110$

61 Comparison of service times of a single server and multiple server systems 111

62 Model of an underground connection $\quad 113$

63 Principle of LMCS 114 
64 QC with a single spreader

65 QC with dual crabs and traverser

66 QC withdual spreader

67 QC with elevators

68 Fixed cost per TEU and per day, dependent of the seize of the vessel

69 Impact of the speed of the vessel to fuel consumption

70 Real examples of the impact to transportation cost of a container per day by lowering the speed and increasing the load factor

71 Transport cost of different carriers 2012

72 Seafreight transport leadtime 2011

73 Variable transportation cost ( seaside ) of 1 TEU/day

74 The staytime of a vessel at the berth per TEU in seconds, depending On the vessel seize

75 Total landing and staycost in the harbor for 24 hours per TEU

76 Total cost per TEU and day ( seaside transport, harbor staytime )

77 Total cost distribution for a transport from Asia through the Suez-canal to the harbor Hamburg

78 Example for $\mathrm{CO}_{2}$ pollution for different transportation systems

79 Example of comparison between truck and train transportation cost in Finland 138 
\&+\$37( 5 Шा

१,1752' $8 \& 7,210$

\subsection{MARKET ISSUES}

The global growth of economy will nearly double the economy performance during the years 2010 and 2025 (see figure 1).

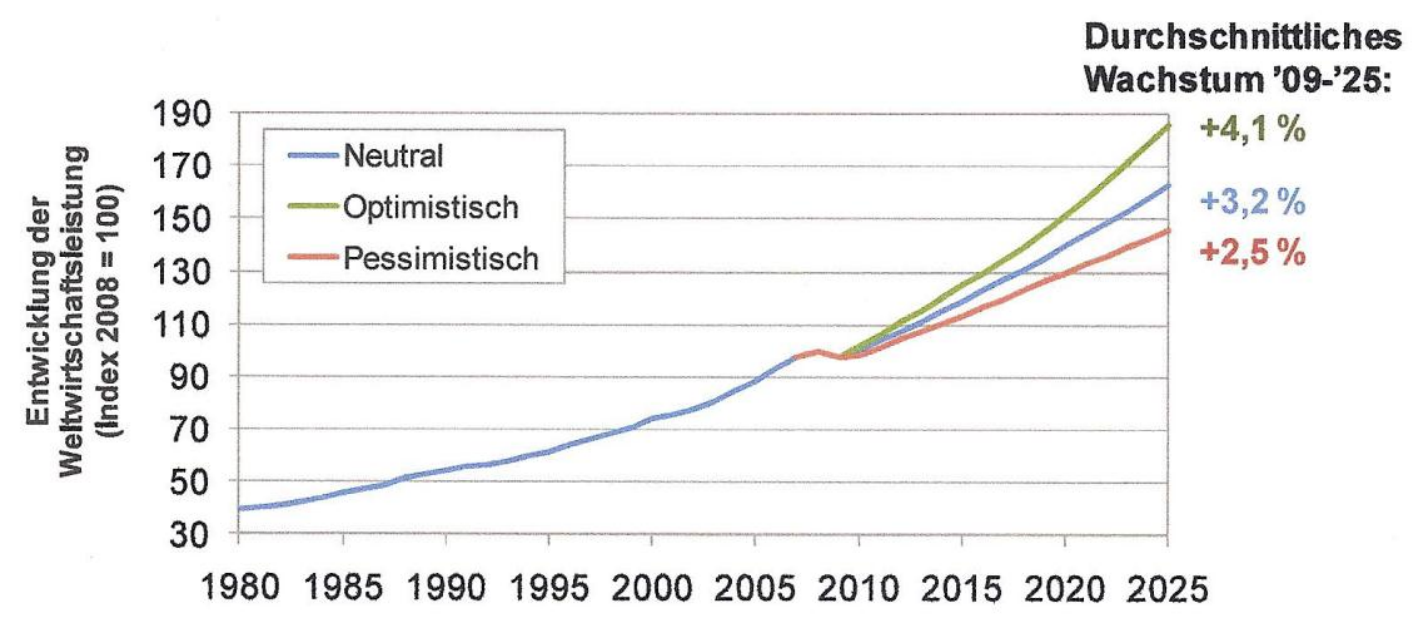

Figure 1: IHS prognostics for growth of the world economy, ( after ISL (2010)

Note : European notation is used for numeration in the entire dissertation.

In Figure 1 are shown 3 scenarios with an avg. growth between 2009 and 2025 of 4,1\% ( optimistic ) 3,2\% ( neutral ) and 2,5\% (pessimistic ). Consequently the transportation 
volume of materials, goods and finished products will increase as well. The globalization raises logistic challenges between Asia, Europe, Australia and the Americas. Containers become more and more important and have very fast yearly growth-rate (Figure 2).

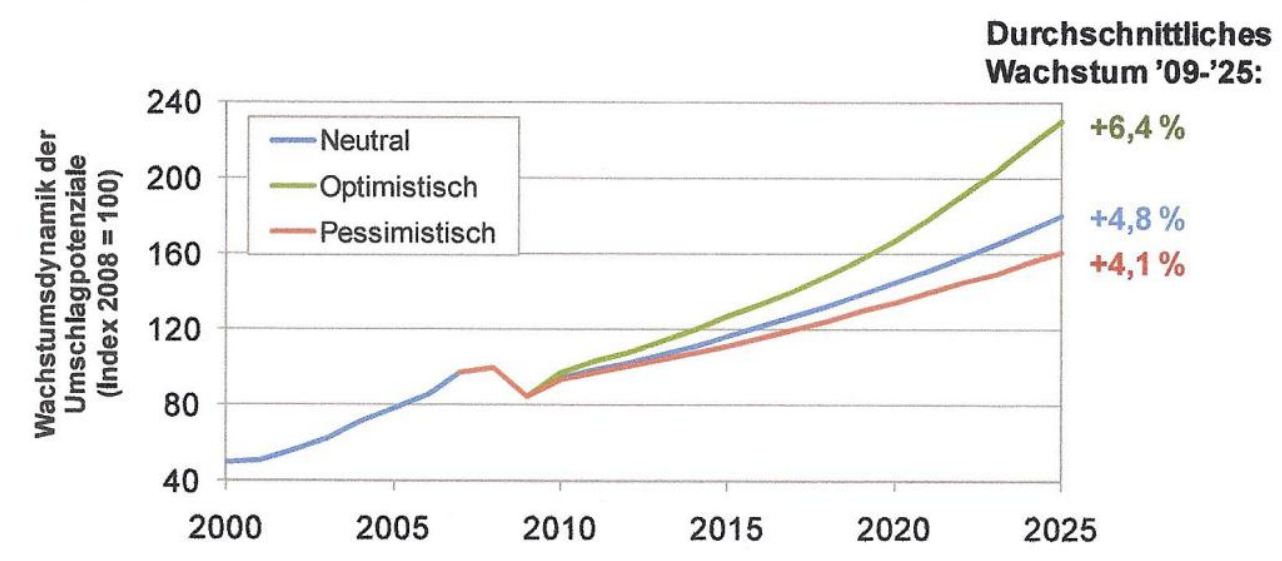

Figure 2: IHS prognostic of world container transport. ( after ISL (2010))

The average growth of the container transportation business between 2009 and 2015 is shown in figure 2 in 3 scenarios $6,4 \%$ (optimistic) 4,8\% ( neutral ) and 4,1\% (pessimistic ).

\subsubsection{Container Fleet and Future Outlook.}

Due to this growth, the fleet of container vessels has continued to increase. Furthermore the size of the vessels has grown from a value of around 8000 TEU in 2005 up to $16000 \mathrm{TEU}$ in 2012. In 2009 the total container vessel fleet was 4691 vessels and 1087 vessels were ordered. Figure 3 shows the fleet and the orders related to the size in 
2009. In 2013 the first ships with a capacity of 18000 TEU will come into service. Vessels with a capacity of 22000 TEU are planned for the year 2018. There may be some limitations for Canals ( Panama, Suez ) and harbours due of the size (length, width and depth ). However, harbors will be faced with new challenges to improve their loading and unloading processes.

Table 1 : Existing fleet ( different seizes ) and ordered vessels ( after ISL ( 2010 )

\begin{tabular}{crrrrrrr} 
& \multicolumn{2}{c}{ Auftragsbestand } & \multicolumn{2}{c}{ Fotte } & \% Auftrags bestand \\
TEU-Klasse & 1000 TEU & $\begin{array}{r}\text { Anzahl } \\
\text { Schiffe }\end{array}$ & 1000 TEU & $\begin{array}{r}\text { Anzahl } \\
\text { Schiffe }\end{array}$ & TEU & Anzahl \\
\hline unbekannt & - & - & 0 & 18 & - & - \\
$<1.000$ & 86 & 117 & 698 & 1143 & 12,3 & 10,2 \\
$<2.000$ & 327 & 221 & 1.769 & 1249 & 18,5 & 17,7 \\
$<3.000$ & 231 & 89 & 1.862 & 733 & 12,4 & 12,1 \\
$<4.000$ & 208 & 60 & 1.212 & 352 & 17,2 & 17,0 \\
$<5.000$ & 884 & 202 & 2.140 & 488 & 41,3 & 41,4 \\
$<6.000$ & 235 & 44 & 1.571 & 286 & 15,0 & 15,4 \\
$<7.000$ & 426 & 65 & 976 & 150 & 43,7 & 43,3 \\
$<8.000$ & 204 & 28 & 494 & 67 & 41,3 & 41,8 \\
$<10.000$ & 787 & 91 & 1.498 & 175 & 52,5 & 52,0 \\
$<12.000$ & 358 & 34 & 193 & 18 & 185,3 & 188,9 \\
$>=12.000$ & 1.788 & 136 & 156 & 12 & 1145,4 & 1133,3 \\
\hline Gesamt & 5.535 & 1.087 & 12.569 & 4.691 & 44,0 & 23,2
\end{tabular}

Table 1 shows that there are 4691 vessels existing with a capacity of 12,569 million TEU and that there are already 1087 vessels ordered with a total capacity of 5,535 million TEU, which means about $44 \%$ of the existing capacity. These figures show the high dynamic of the container transportation business. 


\subsubsection{Harbor situation.}

The transportation volume in tons is increasing, but the transportation volume with containers is increasing much faster. In the north range in Europe (Rotterdam, Antwerp, Hamburg, Bremen) the expected volumes will increase by 2025 by 75 million TEU. Everythere the capacities in the harbours are growing. Table 2 shows some figures about predictions.

Table 2: Planned container capacities of harbours ( own investigation ).

\begin{tabular}{|l|l|l|}
\hline harbour & capacity 2010 & capacity 2025 \\
\hline Rotterdam & 13 million TEU & 34 million TEU \\
\hline Long Beach & 12 million TEU & 57 million TEU \\
\hline Hamburg & 9 million TEU & 25 million TEU \\
\hline
\end{tabular}

Most of the harbors in the world have a tradtional infrastructure and have reached its capacity limit for managing the container logistics. Figure 3 shows a typical layout of a traditional container terminal with a wide area of container stacking in the yard. Everywhere in the world the intermediate stackings in the habors can be seen. Multiple handling of containers ( between 3 and 4 times in average ) until the container leaves the yard and a storage time over days is a "normal" process. These handlings have no added value and only drive cost. 


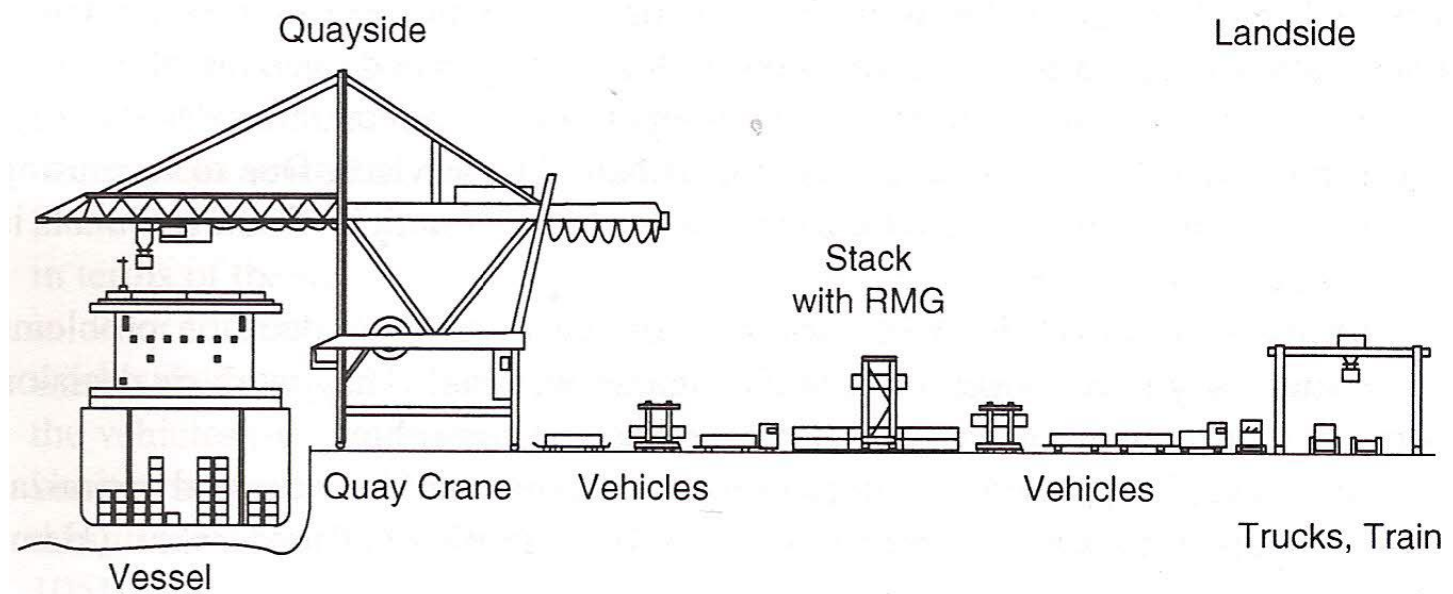

Figure 3 : Typical layout of a container terminal ( after Kap Hwan, Kim, H.O.Günther

( 2005 ), Containerterminals and automated transport systems ).

The harbor areas with the traditional layout have limited potential for expansion. Figure 4 shows the throughput density of the top North Amercian Ports. Compared to Asian port and big hubs in Europe, US harbors are using much more area per container, which means longer transportation waits. The higher throughput means a bigger efficiency and productivity in the yard. This will be the challenge for most harbors with the fast growing business. 


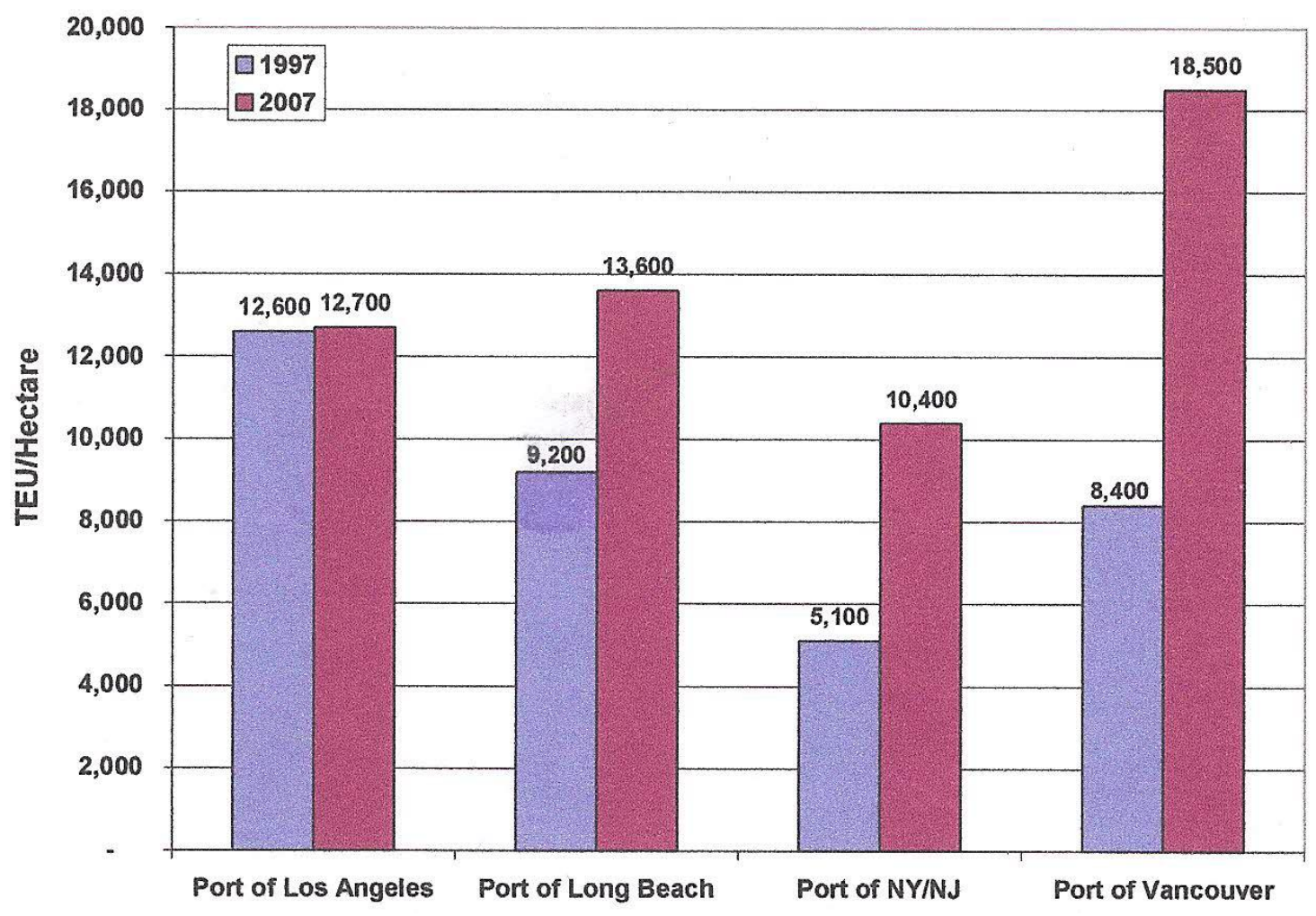

Figure 4: Throughput Density TEU / hectare ( after Vijay Agraval ( 2010 ) ).

Compared to the following ports :

$\begin{array}{lll}\text { Hamburg } & : & 23000 \mathrm{TEU} / \text { hectare } \\ \text { Rotterdamm } & : & 18000 \mathrm{TEU} / \text { hectare } \\ \text { Singapore } & : & 46000 \mathrm{TEU} / \text { hectare } \\ \text { Hongkong } & : & 85000 \mathrm{TEU} / \text { hectare } \\ \text { Shanghai } & : & 31000 \mathrm{TEU} / \text { hectare }\end{array}$

There is a significant amount of room for improvements, which is necessary with the fast growing container volume and the limited space. 
Table 3 show the existing and planned automated container terminals. All of them are planning stacking in the yard except Brisbane, which plans a direct transportation with Autostrads out of the yard. This seems quite strange as most of the harbors with a high Hinterland modalsplit part are today already faced with traffic problems and will grow fast during the next years. Their focus is still in improving the processes in the yard with given traffic structure and a better traffic control.

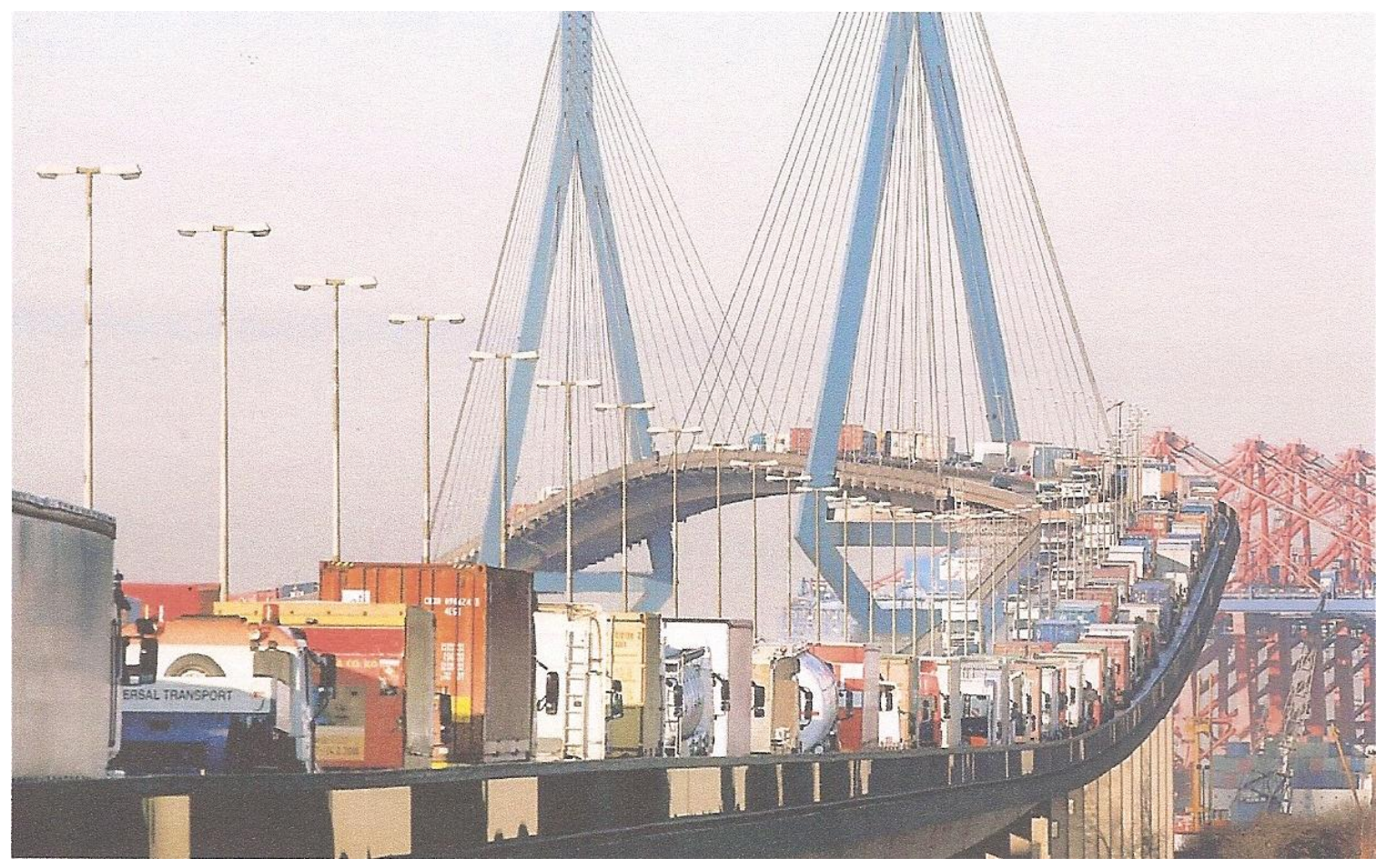

Figure 5 : Daily traffic jam in the harbor of Hamburg (Picture of HamburgerAbendblatt)

Nethertheless, the financial crisis in 2009 and the ongoing econonic problems in Europe and USA have lowered the growth and there is already an overcapacity in the moment of vessels. This causes a decrease in the transportation cost. Until October 2013 about 400 vessel fonds went into bankrupcy. 
Table 3 : Overview of some selected existing or planned automated container terminals ( after : Vijay Agraval )

\begin{tabular}{|c|c|c|c|c|}
\hline Location (start date) & $\begin{array}{l}\text { Yard Cranes } \\
\text { per block }\end{array}$ & $\begin{array}{l}\text { Stack width } \\
\text { (boxes) }\end{array}$ & $\begin{array}{l}\text { Waterside } \\
\text { transport }\end{array}$ & Landside transport \\
\hline ECT Rotterdam (1993) & 1 & 6 & $\begin{array}{l}\text { AGVs to end of } \\
\text { ASC }\end{array}$ & $\begin{array}{l}\text { Trucks served via } \\
\text { strad interface }\end{array}$ \\
\hline Thamesport & $\begin{array}{l}2 \text { on same } \\
\text { rails }\end{array}$ & $9 / 7$ & $\begin{array}{l}\text { Trucks drive to } \\
\text { side of ASC }\end{array}$ & $\begin{array}{l}\text { Trucks back-in to } \\
\text { landside of ASC row }\end{array}$ \\
\hline CTA Hamburg (2002) & $\begin{array}{c}2 \text { on } \\
\text { separate rails }\end{array}$ & 10 & $\begin{array}{l}\text { AGVs to end of } \\
\text { ASC }\end{array}$ & $\begin{array}{l}\text { Trucks back-in to } \\
\text { landside of ASC row }\end{array}$ \\
\hline $\begin{array}{l}\text { Patrick Terminals } \\
\text { Brisbane (2003) }\end{array}$ & N/A & 1 & Autostrads & Autostrads \\
\hline APMT Norfolk (2007) & $\begin{array}{l}2 \text { on same } \\
\text { rails }\end{array}$ & 8 & $\begin{array}{l}\text { Manned shuttles at } \\
\text { end of ASC }\end{array}$ & $\begin{array}{l}\text { Trucks back-in to } \\
\text { landside of ASC row }\end{array}$ \\
\hline DPW Antwerp (2007) & $\begin{array}{l}2 \text { on same } \\
\text { rails }\end{array}$ & 10 & $\begin{array}{l}\text { Manned shuttles at } \\
\text { end of ASC }\end{array}$ & $\begin{array}{l}\text { Trucks back-in to } \\
\text { landside of ASC row }\end{array}$ \\
\hline $\begin{array}{l}\text { Euromax Rotterdam } \\
\text { (2008) }\end{array}$ & $\begin{array}{l}2 \text { on same } \\
\text { rails }\end{array}$ & 10 & $\begin{array}{l}\text { AGVs to end of } \\
\text { ASC }\end{array}$ & $\begin{array}{l}\text { Trucks back-in to } \\
\text { landside of ASC row }\end{array}$ \\
\hline CTB Hamburg (2009) & $\begin{array}{l}3, \text { on two } \\
\text { sets of rails }\end{array}$ & 10 & $\begin{array}{l}\text { Manned shuttles at } \\
\text { end of ASC. }\end{array}$ & $\begin{array}{l}\text { Trucks back-in to } \\
\text { landside of ASC row }\end{array}$ \\
\hline $\begin{array}{l}\text { NYCT New York } \\
\text { (planned for 2010) }\end{array}$ & $\begin{array}{l}2 \text { on same } \\
\text { rails }\end{array}$ & $11 / 9$ & $\begin{array}{l}\text { Trucks drive to } \\
\text { side of ASC }\end{array}$ & $\begin{array}{l}\text { Trucks back-in to } \\
\text { landside of ASC row }\end{array}$ \\
\hline $\begin{array}{l}\text { PAG Oakland } \\
\text { (planned for 2013) }\end{array}$ & $\begin{array}{l}2 \text { on same } \\
\text { rails }\end{array}$ & 8 & $\begin{array}{l}\text { Manned shuttles at } \\
\text { end of ASC }\end{array}$ & $\begin{array}{l}\text { Trucks back-in to } \\
\text { landside of ASC row }\end{array}$ \\
\hline
\end{tabular}

\subsubsection{Freight cost situation:}

A measure for the shipping cost is i.e. the Harpex Index ( figure 6 ). Other similar indices are ConTex and HRCI. The charter rates of 7 classes of ships, sizes, speed and contract times are collected from brokers and shippers on a daily basis and calculated to 
an index for freight rates ( the index does not include fuel cost, insurances and considers just the rental rate for the vessel ). Remark: for total transportation cost there are other box-indices available.

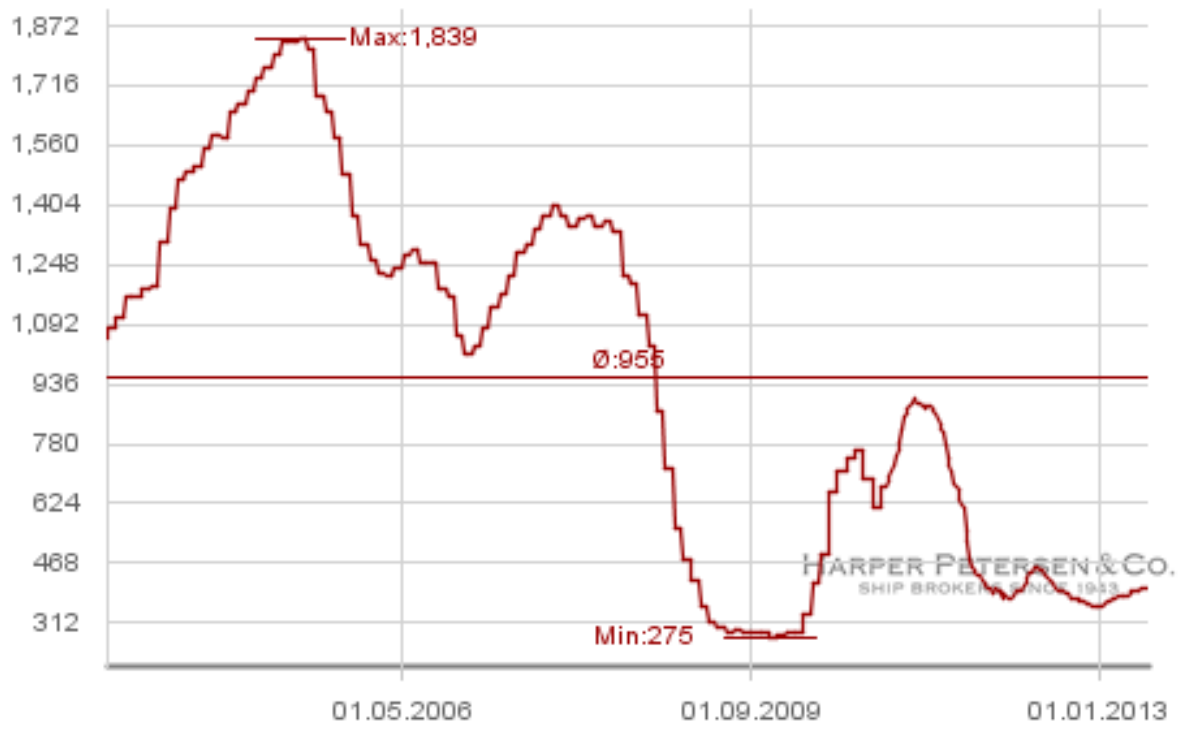

Figure 6 : Harpex Index of sea-freight rates ( Harpex )

This shows that the actual rental rates are quite low and most of the shipping companies are suffering and cannot cover their cost. Due to existing overcapacities and the growth of the container vessel fleet with the bigger sizes of $>15000$ TEU in the next years, the freight rates will stay under pressure. The need for more productivity and cost reduction along the whole transportation chain will become more and more important. 
Table 4 : Harpex rates related to the vessel size. ( Source Harpex database )

\begin{tabular}{|l|l|l|l|l|l|l|}
\hline Date & $\begin{array}{l}\text { Harpex } \\
\text { Index }\end{array}$ & \multicolumn{5}{|l|}{ Vessel seize in TEU } \\
\hline 22.06.2013 & 401 & 700 & 1700 & 2700 & 4250 & 8500 \\
\hline Rates per & In US \$ & 4100 & 7250 & 7100 & 9000 & 36000 \\
vessel & total & & & & & \\
\hline Rates per & in \$ per & 5,85 & 4,26 & 2,63 & 2,12 & 4,23 \\
TEU & day & & & & & \\
\hline
\end{tabular}

These results ( rental calculated with full loaded vessels ) show that small and big vessels have much higher rates while those in the midrange ( $2000-6000$ TEU ) offer the opportunity for significant competition.

\subsubsection{Market conclusion}

To summarize the actual situation: The container transportation market will increase extraordinarily. The vessels will become bigger with higher load capacity. To be more efficient the vessels must be loaded and unloaded faster. The volume in the harbors will increase and due to limited space the throughput of the containers must be accelerated. The pressure to reduce costs in the logistic chain will enforce new processes. Figure 7 shows that more than $80 \%$ of the total transportation cost from Asia - 
Hongkong to Europe Hinterland - Munich ) are landside caused. 96,6 \% of the total distance ( Hongkong-Bremen/Hamburg ) are only responsible for 3,4\% of the logistic cost. This gives a direction where the big potential for cost reduction can be found. This example shows that it is worth to analyze the landside logistic processes and to make improvements. The growing container market will pressurize the development of new innovative logistics.

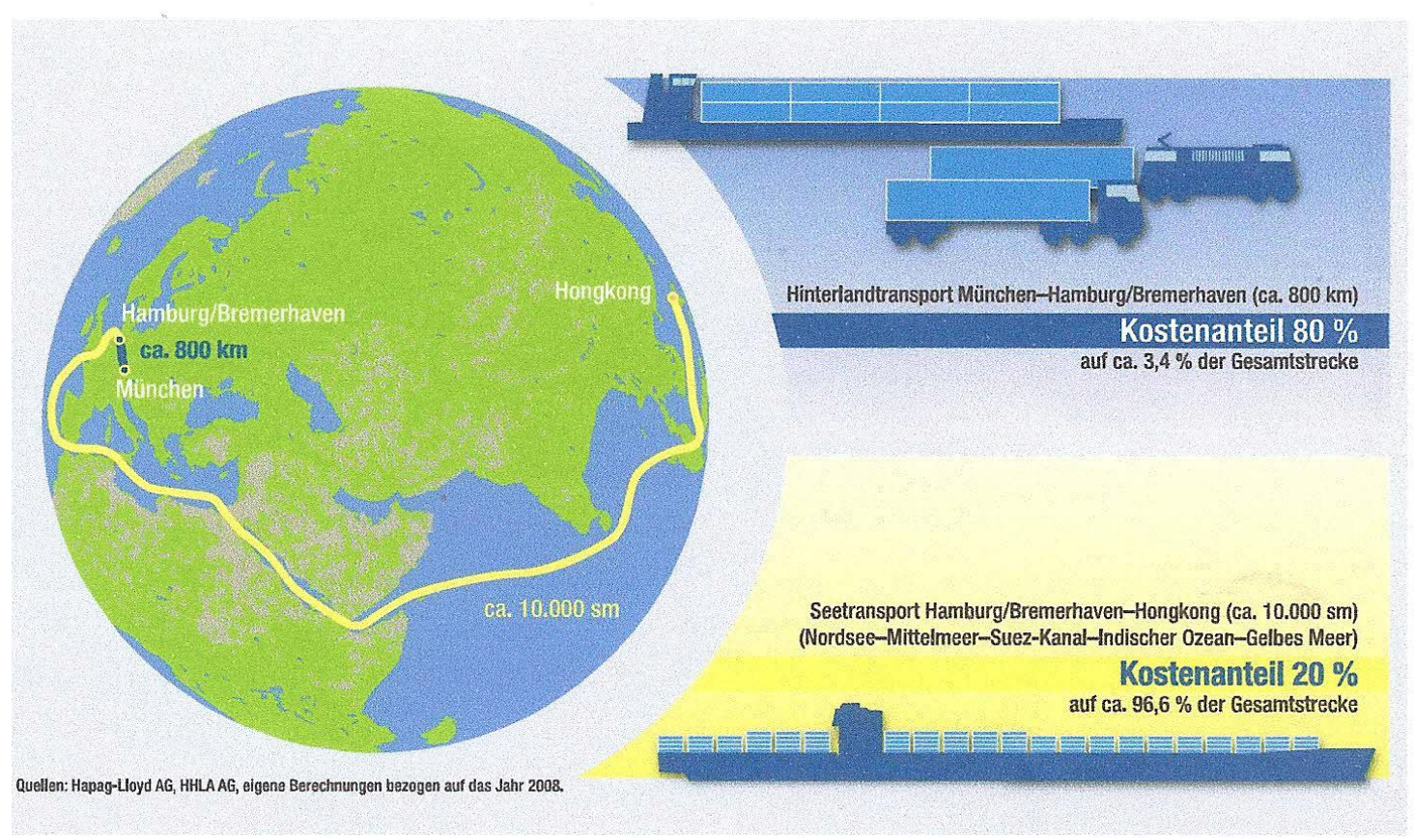

Figure 7 : Cost-structure of seatransport and Hinterlandtransport ( after IHK-Nord ) 


\subsection{CURRENT STATUS IN CONTAINER LOGISTICS}

1.2.1 Existing logistic processes in container transportation chain.

Today there are different players in the logistic chain with different interests and not linked processes :

- customer: wants to have his goods as fast as possible

- supplier: needs to ship his goods as soon as possible via his carrier from his plant to the harbour

- ocean carrier: needs to load his vessel as fast as possible. He collects the container at different harbors ( e.g.in Asia ) and transport them to different ports in Europe. To keep a high loading factor, he always load and unloads containers at each port. He tries to keep a certain block structure related to the destinations. There are, however some special treatments (dangerous goods, perishable items and weight distribution in the loading process) that must be considered. Nethertheless, there are maybe up to $30 \%$ empty containers ( see Figure 8 ). The vessel only makes money if it is moving. Downtimes in harbors or waiting time in front of the harbors ( very well demonstrated in Long Beach or Singapore ) are lost time, cost money and reduce efficiency. 


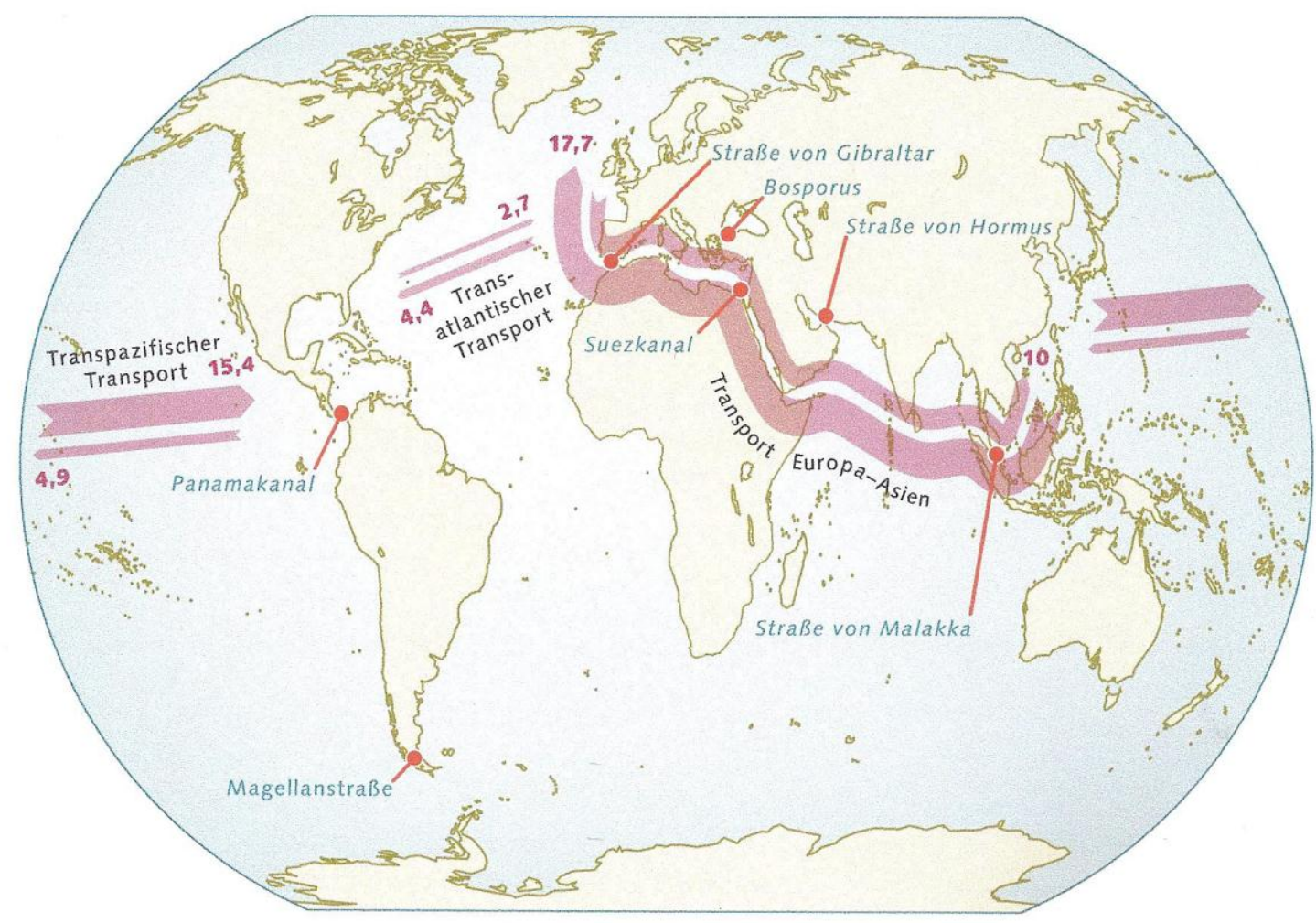

Figure 8: $\quad$ main routes of containers with TEU distribution ( after Maribus ( 2010 ))

The freight streams illustrate the problems, that many more goods are being transported from Asia to Europe or to North America than the reverse. Consequently the empty containers must be shipped back to Asia. The ocean carrier has the necessity to load and unload his vessels efficiently, due to the high cost per day for staying at the berth.

- harbour terminal: They are responsible for the loading and unloading process, the storing of the containers and for loading and unloading of trucks, trains, feeders to/from the "Hinterland" distribution. They earn money, beside the harbor fee for each move of a container and for warehousing. As long they have enough space, 
they have no need to accelerate the turn-over time, because they make money with each move and each day of storing ( after a free period ).

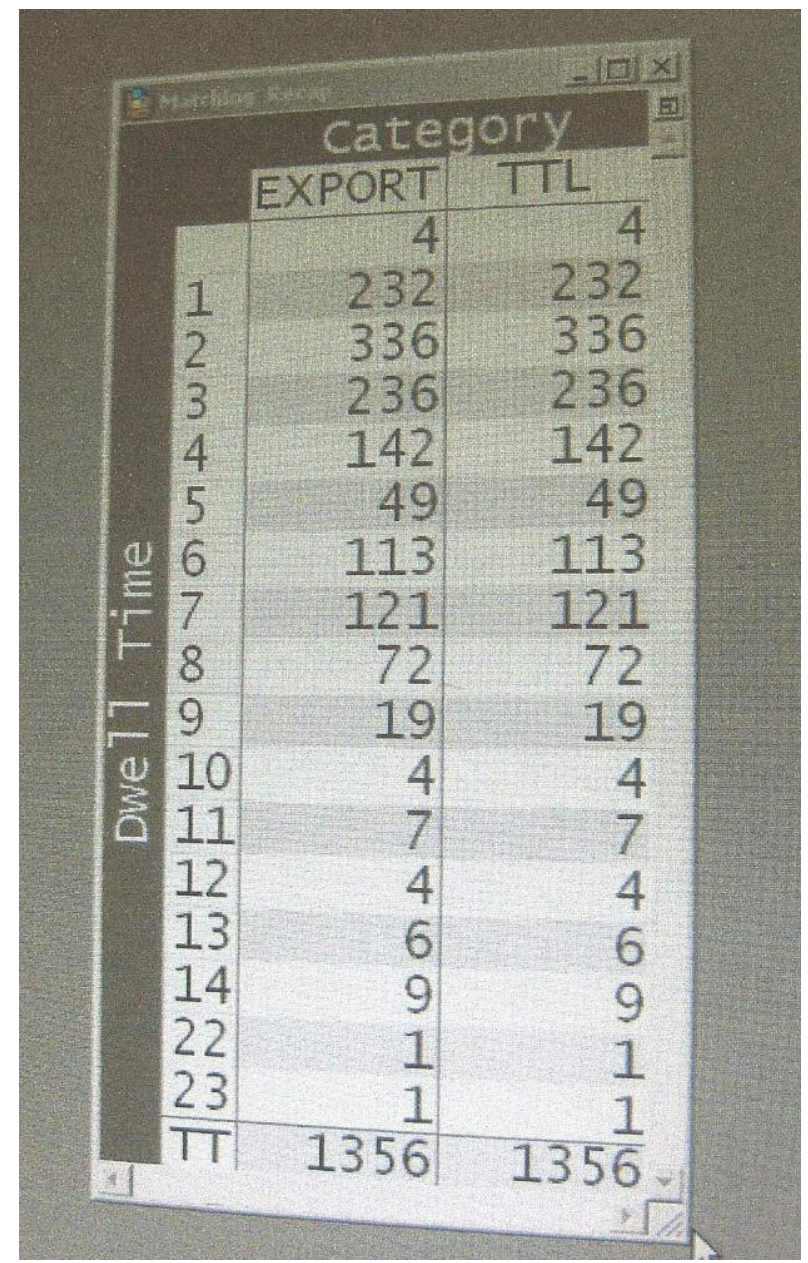

Figure 9 : Staytime of containers in the yard Auckland /NZ. (Source: own picture )

- Hinterland Carrier : There are two types of carriers, the first ones are mainly trucks, who transport the containers to warehouses within the harbor region. The second one brings the containers to a final customer or to a distribution hub of the carrier. The carrier can be a truck or a train. The Hinterland-Carriers are loaded directly at the terminal. In consequence there is a traffic culmination. More and 
more the ideas of Dryports are developed. Therefore the containers are transported immediately out of the yard ( mostly by train ) and then distributed.

- feeder: These are small vessels, which transport about some hundred containers to smaller ports or on rivers to inland ports. Often they are operated by ocean carriers. The specific members in the container logistics like handling agents, rental companies for containers, customs and state authorities will not be considered. An integrated process with all players is non-existent due to their different interests and targets.

There is no entire process chain with fixed workflow and flow management between these actors. The interfaces are managed separately.

\subsubsection{Existing logistic process in the harbour}

Four major types of yard side equipment are used in normal seaport terminal operations:

- the on-chassis system : the quay crane puts the container to truck \& chassis

- the carrier direct system : the quay crane puts the container to a straddle carrier

- the straddle carrier relay system : the quay crane puts the container to a straddle carrier and a yard crane puts the container to the storage

- the yard crane relay system : the quay crane puts the container on an AGV ( automated guided vehicle ) as a prime mover and the yard cranes place the container to the storage. 
In all 4 types the container are moved into a buffer storage before they are sent to the customer ( either by trucks or by railways or to an intermediate distribution center by feeder boat ). In the buffer storage the containers are stacked up to 6 containers in height. In average the container stays between 3 and 4 days ( picture 8 ) until they are picked up by the logistic service company. If the dedicated container is on the ground of the stack, the others above must be moved and placed in other positions. In average each container has to be moved more than 3 times. In all 4 types, the containers are picked up for transportation within the harbor area, including the customs clearing and finishing the shipping documents. This means a lot of traffic in the yards and, if more than $70 \%$ of the containers are picked up by truck a lot of traffic into and out of the harbor area with traffic jams and pollution ( see picture 5 ) is created. There are some new developments implemented or in planning :

- quay-crane guided and controlled from central control office with cameras (nobody is on board of the crane, so the crane-crab can be accelerated faster and the cycle time reduced by about 30\%)

- quay-crane can pick up 2 containers in 1 stroke and thereby double the capacity

- The Chinese company ZPMC has a demonstation system in Shanghai with a fully automated quay-crane system and an automated container yard stacking-system in place. But they still do an intermediate stacking. 


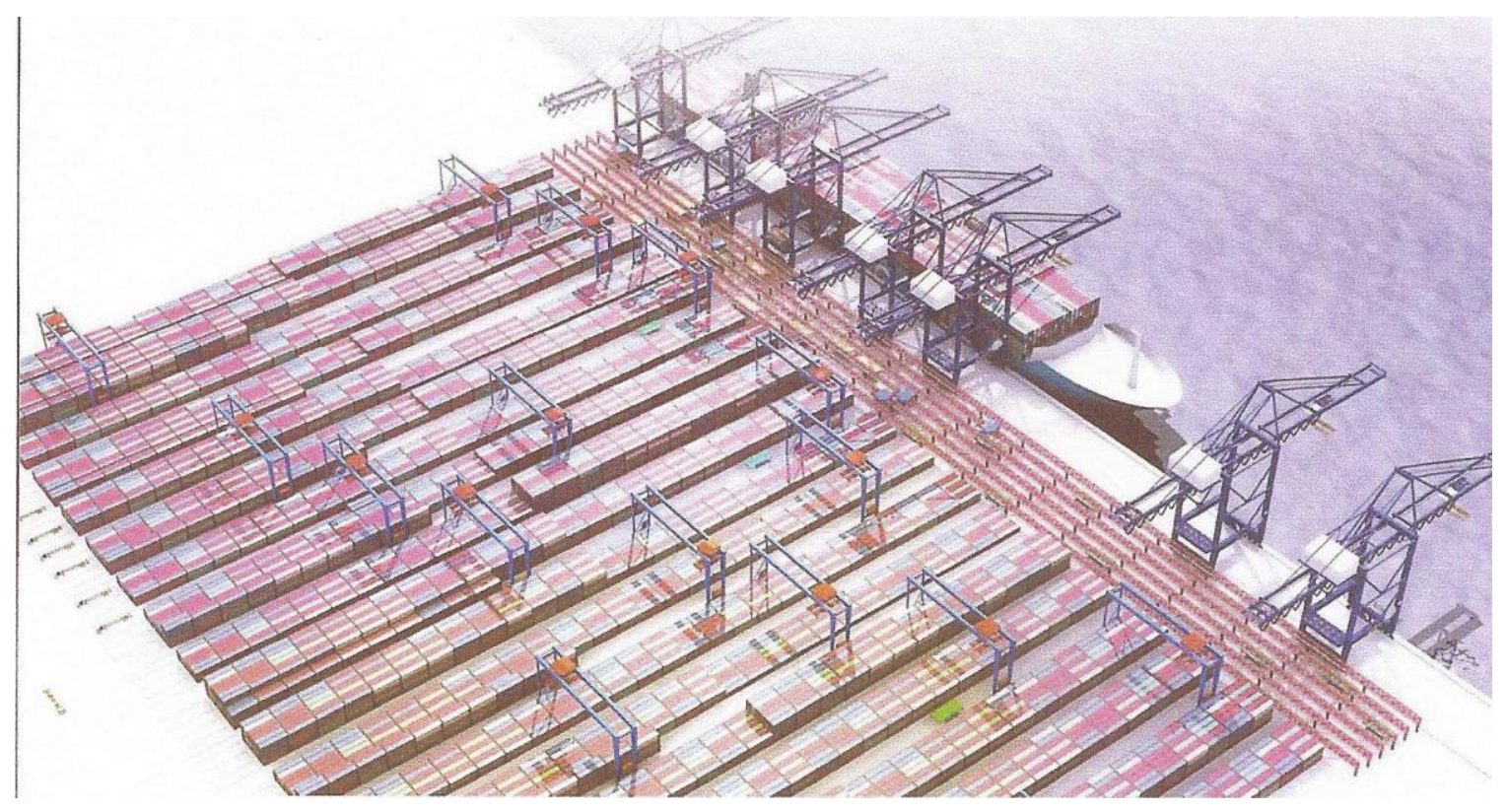

Figure 10 : ZPMC Automated Container Yard Stacking System with Automated Tandem or Triple QCs ( after brochure of ZPMC )

\subsubsection{Targets and guide lines for improvements of the container logistic chain.}

Ships an harbor systems are very high capitalized and are causing high operational cost. To make these equipments more efficient, the turnaround-time of a ship (unloading and loading time) must be minimized. Optimization of the throughput and the operational cost of a harbor system are advantages in the competition.

These are the guidelines for further research:

- total turnaround time of a ship

- total throughput time of a container from pick up on the ship until 
reaching the final destination

- total handling events of a container from pick up on the ship until

loading to the transportation vehicle ( truck of train ) to the final destination.

- total stay time of a container in the harbor ( from arrival of the ship until leaving the harbor ).

- total number of handlings of a container

- total handling time of a container

- disturbances in the different processes and their reasons

- lost time due of disturbances

- grade of service and deviation of the due time

- necessary workforce and personal cost

- number of handling damages and cost

- total handling cost 


\subsection{Research Objectives.}

Learning from the logistic processes within the automotive industry with a mainly „pull-system“, an ideal harbour-Hinterland-customer logistic system should have:

- minimum of storage

- one piece flow

- minimum of handling (avoid multiple handling of the same item)

- Just in time / sequence supply (Jit,Jis)

- automated flow out of the yard

- immediate flow out of the yard

- no trucks / carrier traffic in the yard for picking up containers

- one central coordination / responsability for all movements / trucks/trains/

- feeders and administration processes

- decentral hubs / satellites in certain distance from the yard to avoid

- culmination of truck traffic.

- central empty container management

- integration of the vessel loading with reverse processes

- full flexibility for the modal split to cover all major cases of ports

- where are the most critical processes

- where are possible bottlenecks

- influence of reliability /availability of the equipment 
$\&+\$ 37(5 \square \square$

/,7(5\$785( $\square 5(9,(:$

\subsection{GENERAL REVIEW}

Up to now there is no single actor, who his responsable for planning and coordinating the entire container logistic chain. Each actor is planning his process and is optimizing in his area. Between the single processes in the chain, there is a lot of dead time, in which the product does not create any added value. Lost time is causing cost. The end customer has the products with an avoidable delay in hand. This process chain of a tradional harbor is described as followed : 


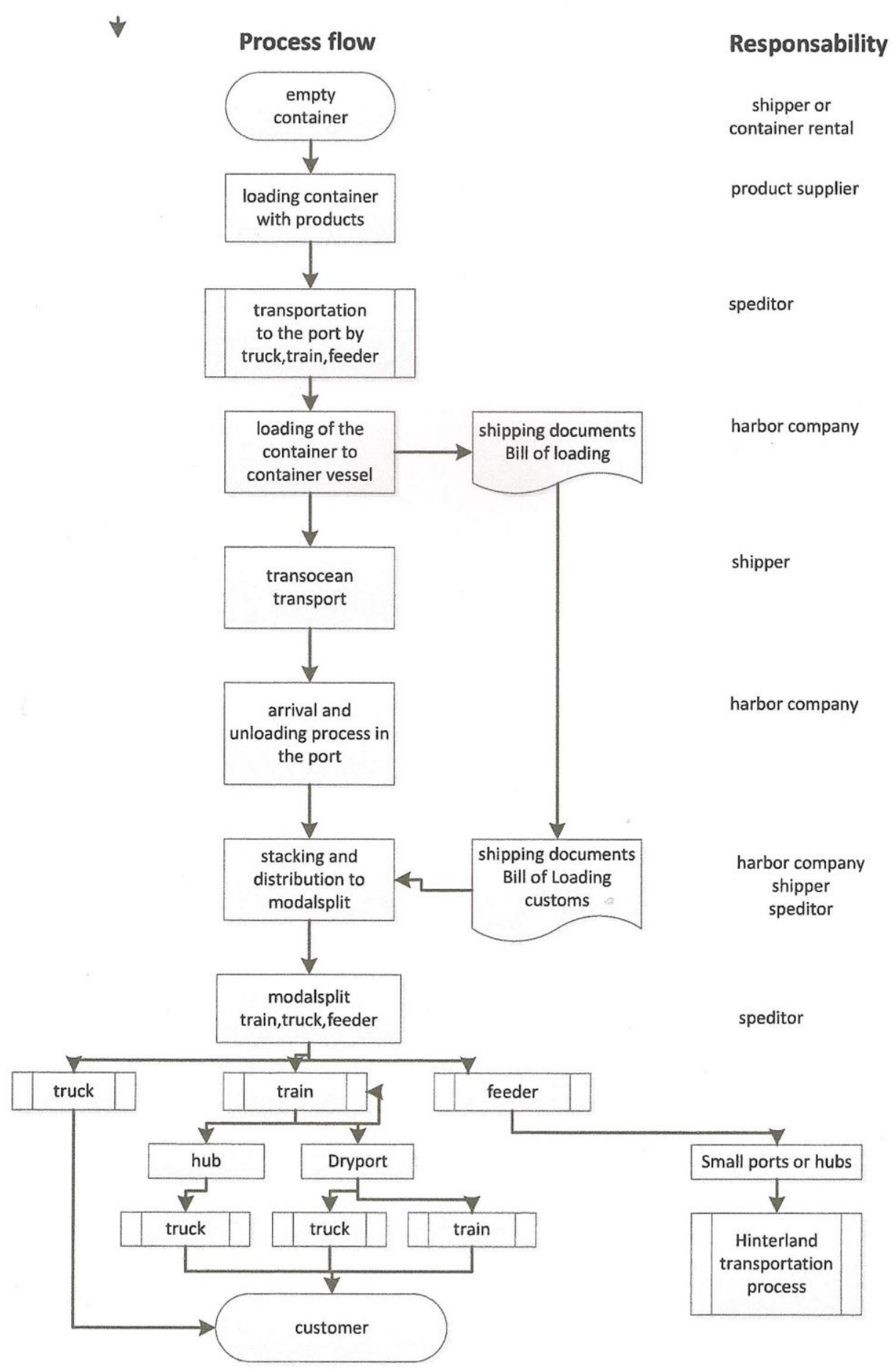

Figure 11 : The container logistic chain 
As already mentioned, during the logistic chain, there are different players with different interests. So there is no real driver for integration and optimization of all logistic steps. I found a company solutions, i.e.BMW. BMW is loading containers in Munich with ckd parts for their plant in Spartanburg / USA. The containers are sent by train to Hamburg or Bremen harbor to an ocean carrier, who make the transfer to the harbor of Rochester. BMW has organized, that the BMW containers are loaded in the harbor direct to trains without any storing. This is possible, because BMW has always some hundred containers and is organizing the chain themselve. „Normal“ customers are relating to the schedule and organization of the players in the chain, with all the security buffer stocks. Meanwhile, most of the harbors worldwide are looking for solutions to increase the throughput of containers. The fast growing container transportation market, the limited space and growing traffic problems combined with the pressure of reduction of pollution is creating research studies. Already in 2001, Iteris company Meyer, Mohaddes Associates have submitted to the ports of Los Angeles and Long Beach a transportation study. They made several simulations of traffic situations and came up with the proposal to spread the truck traffic throughout the whole day. And even then, the situation in the 2020 with a predicted volume of 36 million TEU, the mobility of the Freeway users will not be achieved. In December 2006 Parsons submitted to the ports the "San Pedro Bay Ports Rail Study Update”. They stated that the revised cargo growth will reach in 2030 42,5 million TEU. They are focussing on traffic constraints of the existing transportation systems. The proposed solution was to increase the transportation by railway. On-dock rail yards shall be developed and the containers shall be loaded at the marine terminal direct to trains withthout using trucks. Parson shows that one single on-dock train can 
eliminate 750 truck trips. Related to 2006 , the throughput capacity will be doubled by the train and will remove 6000 trucks a day. Considering the prognostic volume by 2030 , 29000 truck trips can be removed. The other aspect is the pollution. Parson shows that the fuel efficiency of trains is 2-4 times higher than trucks and the trains are 2-3 times cleaner than trucks ( see figure 12).

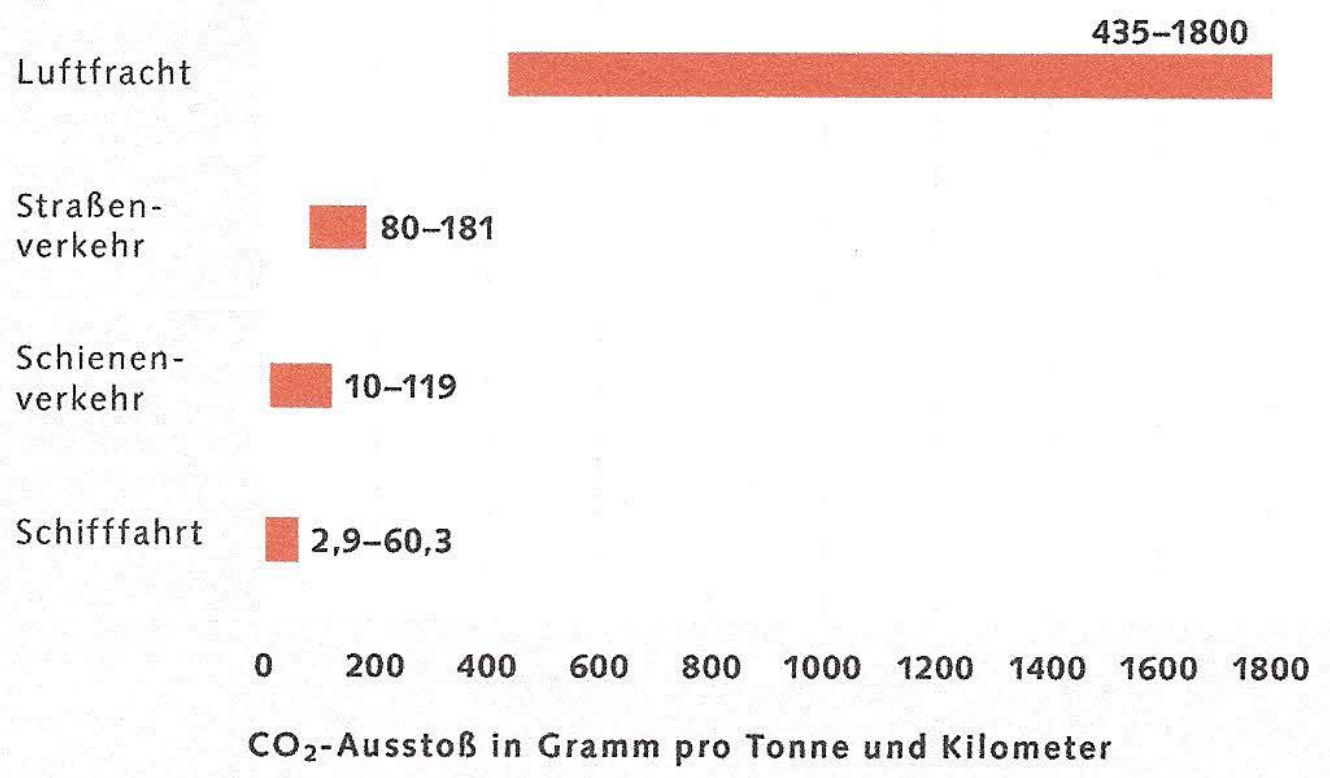

Figure 12 : Pollution of different carriers ( after Maribus 2010 ).

Figure 12 compares the $\mathrm{CO}_{2}$ pollution of trucks, trains, ships and airplanes in grams per kilometer and tons. The pollution discussion becomes quite important, espeacially in harbors, as the big vessels are operated with heavy oil and the trucks have still high emissions. While private households and industry reach reduction in $\mathrm{CO}_{2}$ pollution, the transportation sector has still increase ( see figure 13 ). 


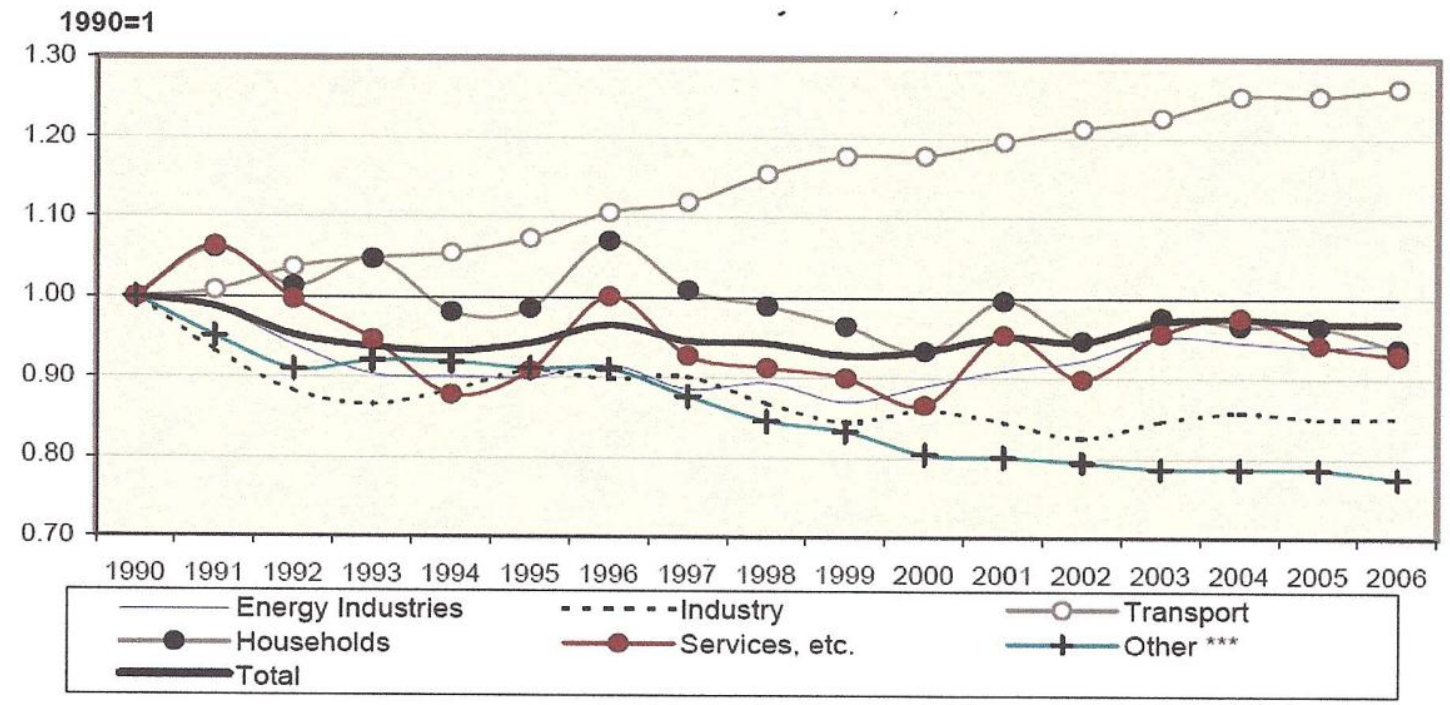

Figure 13 : Pollution of different sectors ( after European Commission 2010,Rickard Bergquist)

The future questions for the container transportation growth and the resulting problems are on the table. The directions where to go seems clear. But most of the research is focused only on single segments in the container logistic chain. They are searching for improvements on existing layouts and equipment. 


\subsection{DRYPORTS}

Considering the last 15 years the most research of Hinterland logistics was focused on Dryports. A Dryport is an inland container terminal, which has a direct connection ( normally by railway ) to the seaport terminal ( Roso et.al.2009). The Dryport can offer terminals for trucks or for railways and has all service functions like a seaport terminal (customs clearing, administration, buffer-store, shipping and receiving of containers, presence of 3rd party logistic, maintenance of containers, empty container handling ). In the simulation model, introduced later on, there are considered satellites functionally as Dryports, which can be in a distance of 5, 10 or 20 kilometers from the harbor. The dry ports are considered to be operated by the railway in the model and have distances of about 100-700 kilometers ( i.e.GVZ). 


\section{Sea Port - Hinterland Connections}

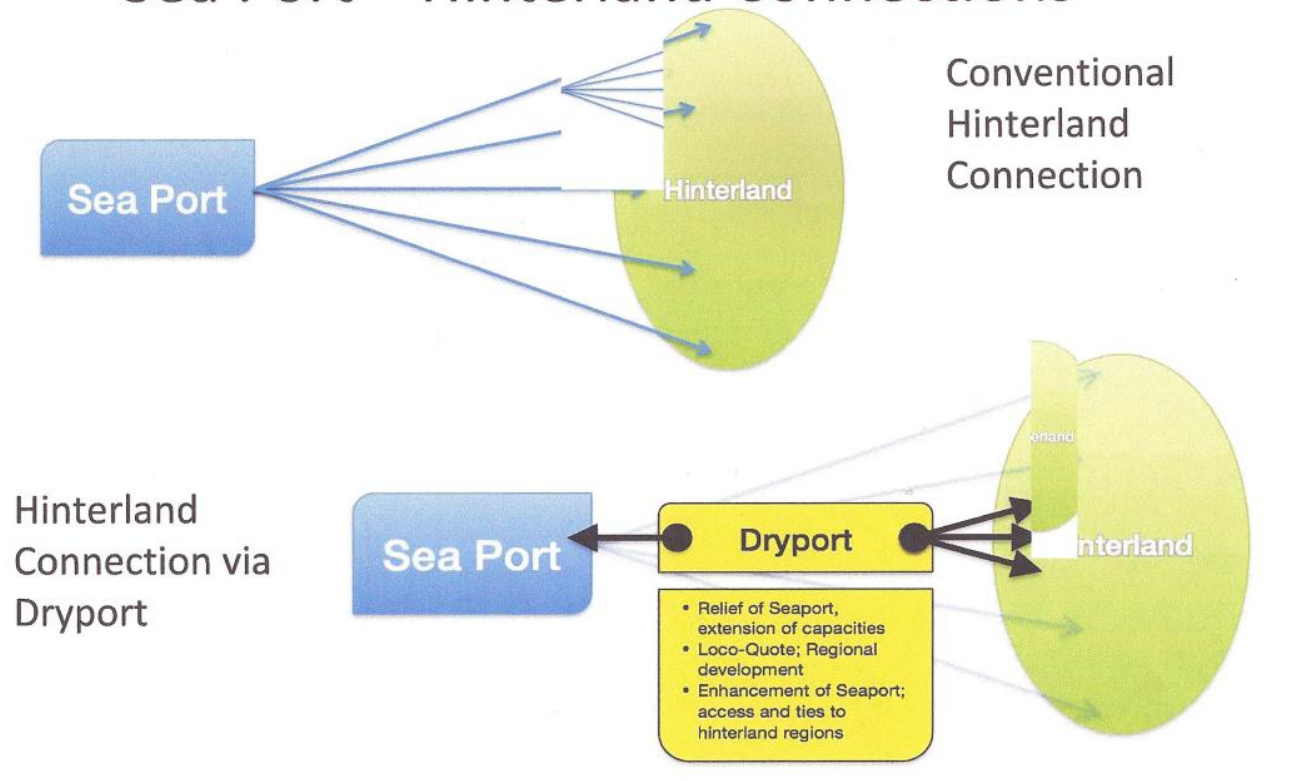

(ن) Universität Bremen

iow

merconemuleng

Figure 14 : The Dryport concept ( after Universität Bremen ( 2010 ))

Roso et.al ( 2009 ) define 3 different types of Dryports

- distant Dryport : one train can substitute 35 trucks in Europe and 100 in USA comment : a train in Europe can carry 100 in USA 300 TEU

- midrange Dryport : > $300 \mathrm{~km}$ from seaport

- close Dryport : near the seaharbor and all sea port services can be offered 
Table 5 : Benefits for actors of the system Dryport ( after Violeta Roso ( 2008 )

\begin{tabular}{|c|c|c|c|}
\hline & Distant & Midrange & Close \\
\hline \multirow[t]{4}{*}{ Seaports } & Less congestion & Less congestion & Less congestion \\
\hline & Expanded hinterland & Dedicated trains & Increased capacity \\
\hline & Interface with hinterland & Depot & Depot \\
\hline & & Interface with hinterland & Direct loading ship-train \\
\hline \multirow{2}{*}{$\begin{array}{l}\text { Seaport } \\
\text { cities }\end{array}$} & Less road congestion & Less road congestion & Less road congestion \\
\hline & Land use opportunities & Land use opportunities & Land use opportunities \\
\hline \multirow{2}{*}{$\begin{array}{l}\text { Rail } \\
\text { operators }\end{array}$} & Economies of scale & Day trains & Day trains \\
\hline & Gain market share & Gain market share & Gain market share \\
\hline \multirow[t]{2}{*}{$\begin{array}{l}\text { Road } \\
\text { operators }\end{array}$} & $\begin{array}{l}\text { Less time in congested } \\
\text { roads and terminals }\end{array}$ & $\begin{array}{l}\text { Less time in congested } \\
\text { roads and terminals }\end{array}$ & $\begin{array}{l}\text { Less time in congested } \\
\text { roads and terminals }\end{array}$ \\
\hline & & & $\begin{array}{l}\text { Avoiding environmental } \\
\text { zones }\end{array}$ \\
\hline \multirow[t]{2}{*}{ Shippers } & Improved seaport access & Improved seaport access & Improved seaport access \\
\hline & 'Environment marketing' & 'Environment marketing' & \\
\hline \multirow[t]{2}{*}{ Society } & $\begin{array}{l}\text { Lower environmental } \\
\text { impact }\end{array}$ & $\begin{array}{l}\text { Lower environmental } \\
\text { impact }\end{array}$ & $\begin{array}{l}\text { Lower environmental } \\
\text { impact }\end{array}$ \\
\hline & Job opportunities & Job opportunities & Job opportunities \\
\hline
\end{tabular}

The driving factors for dry ports are mainly:

- Limited space for growth of seaports to increase capacity of throughput. There is only the possibility to reduce storage of containers on the terminal through reduction of traffic in the harbor and to avoid traffic jams and lost waiting for trucks. V.Roso, 2007, transportation Research, Part D shows in a simulation model that in a traditional seaport queue 23 trucks were still waiting after 4 hours with an average wait time of 85 minutes. In the Dryport model there are only 5 trucks waiting with an average wait time of 13 minutes. 
- reduction of pollution: V.Roso showed in the above expample, that a Dryport reduces the pollution by $25 \%$ or $1300 \mathrm{~kg}$ of carbon dioxide per train / 35 trucks, which means with 2 trains / day a savings of 2000 road kilometer of trucks.

The ports of Los Angeles and Long Beach have started a "ports clean truck program" to limit pollution in their ports. In the study from the Thioga Group "Inland Port Feasability Study" August 2008, prepared for Southern California Association of Governments, the benefits of an inland port concept are obvious but the implementation has a lot of hurdles. They show that a high efficient shuttle train with different technical solutions, like Transrapid Maglev concept, is feasible and reduces transportation time and cost.

The "Dryport" has in different countries other names

- ICD : $\quad$ inland container depot

- GVZ: Güterverteilzentrum (Germany)

- ZAL: Spain

- Interporti : Italy

There are already some activities of seaport-companies to increase vertical integration of landside supply chain. The Hamburg company HHLA is operating a hub train to Poznan (Poland) called Polzug Intermodal. Another cooperation with Vienna (Austria) is on the way. Several GVZ in South Germany, linked by train, are operated as well the past several years. The Rotterdam seaport operator ECT has also made first steps in vertical integration of the logistic chain in buying terminals in Venlo and Duisburg. In USA the first attempts were already made in mid 1980. APL started with the first double stack train from West coast to East coast ( Gordon Wilmsmeier et.al,( 2011 ), Journal of Transport Geography). This route combination was 10 days faster than the seaway 
through the Panama Canal to New York. The newest plan of a "Dryport" is in Long Beach. The existing Intermodal Container Transfer Facility (ICTF), in 8 kilometres distance from the Long Beach Port, handles about 2500 containers a day. An average of 60 trains every day leave the terminal. There are plans to double the existing capacity. In 2002, the Alameda Corridor Expressway from Long Beach port to the transcontinental rail network in 32 kilometres distance was opened to reduce truck traffic in Los Angeles. Daily 42 trains transport 12000 containers. A third railway terminal SCIG with a capacity of 1,5 million containers per year is planned for 2023. Another important project is planned on the East coast. From Virginias ports, the Hartland Intermodal corridor shall link the Hampton Roads area to Columbus / Ohio and Chicago. It seems that the Hinterland logistics is recognized as a field for increasing productivity along the distribution chain and creates a competitive advantage. Today up to $80 \%$ of the total transportation cost along the chain are caused after the containers leave the vessel ( (Figure 7 ).

For implementation of Dryports a number of different interests of the stakeholders are involved:

- Public authorities /

policy/government) : $\quad$ building infrastructure, conflicts with involved cities resistance with citizens, traffic increase, pollution

- private companies in port business $\quad$ :- $\quad$ fear of loosing business

- logistics companies : fear of loosing business and market-share to trains 
Dr. Jean-Paul Rodriguez, and Dr. Theo Nottebohm, described in an article in „Port Technology International Edition ( 2012 ), the necessity of integration of transshipment hubs. Similar conclusions are made in the above mentioned studies from Tioga Group, Parsons and from Rickard Bergquist. The hurdle is, that today nobody feels responsible for the transportation cost from the port yard to the Dryport:

- The ocean carrier is responsible for the cost harbor to harbor.

- The port company wants to keep the business in the port (longer stay, more movements create profit) and keep the service.

- The land carrier wants to run his trucks in long distances. With dry ports he is loosing kilometers

Who is finally responsible for the infrastructure for Dryports ( transportation network, plant, warehouse / storing area, loading and unloading)?

The local and national economy must have an interest in Dryports, as the traffic can be distributed, economic loss in waiting time can be reduced and pollution can be dramatically avoided in the harbor area and in total by operating trains instead of trucks. Doubling or tripling of the future container handling volume and limited space in the harbor area require new solutions and a much faster throughput. Dryports and/or satellites may be solutions. Smaller ports have already detected this chance, as the following Table 6 shows 
Table 6 : Overview of existing Dryports and range of offered services

( Violeta Roso, The Dryport Concept,2009)

\begin{tabular}{|c|c|c|c|c|c|c|c|c|c|c|c|c|c|}
\hline & & & \multicolumn{5}{|c|}{ General info } & \multicolumn{6}{|c|}{ Services } \\
\hline & & & Owner & Started & $\begin{array}{c}\text { TEU a } \\
\text { year }\end{array}$ & $\begin{array}{c}\text { Area } \\
\text { ha }\end{array}$ & $\begin{array}{c}\text { Rail } \\
\text { frequency }\end{array}$ & $\begin{array}{l}\text { Transship } \\
\mathrm{g}, \mathrm{s}, \mathrm{r}, \mathrm{f}^{*}\end{array}$ & $\begin{array}{c}\text { Customs } \\
\text { clearance }\end{array}$ & Storage & $\begin{array}{c}\text { Maintena } \\
\text { nee }\end{array}$ & $\begin{array}{c}\text { Forward } \\
\text { ing }\end{array}$ & Other \\
\hline \multirow{11}{*}{$\begin{array}{l}0 \\
0 \\
0 \\
\vdots\end{array}$} & & Azuqueca de $\mathrm{H}$ & $\operatorname{mix}$ & 1995 & 18000 & 6 & daily & $1 \mathrm{~g}, 3 \mathrm{r}, 1 \mathrm{f}$ & yes & 2,4 ha & yes & yes & $\begin{array}{l}\text { road haulage, } \\
\text { consolidation }\end{array}$ \\
\hline & & Madrid Coslada & mix & 2000 & 60000 & 14 & daily & $3 \mathrm{r}, 3 \mathrm{f}$ & yes & 3,4 ha & no & yes & - \\
\hline & & Santander Ebro & mix & 2000 & na & 10 & daily & $1 \mathrm{r}$ & yes & yes & no & no & vehicle control \\
\hline & 모ำ & Eskilstuna & $\operatorname{mix}$ & 2003 & 45000 & 2 & daily & $2 \mathrm{r}$ & yes & yes & yes & no & $\begin{array}{c}\text { road haulage, } \\
\text { dangerous goods }\end{array}$ \\
\hline & कै & Hallsberg & $\operatorname{mix}$ & 2003 & 65000 & 6,2 & daily & $2 \mathrm{r}$ & yes & 0,4 ha & yes & yes & $\begin{array}{l}\text { road haulage, cross } \\
\text { docking }\end{array}$ \\
\hline & $-\infty$ & Muizen & state & 1994 & 12000 & 4,2 & daily & $2 \mathrm{~g}, 3 \mathrm{r}$ & no & yes & no & no & - \\
\hline & H & Isaka & state & 1994 & 13000 & 10 & daily & $2 \mathrm{r}, 4 \mathrm{f}$ & yes & 1,2 ha & yes & yes & - \\
\hline & in & Matsapha & state & 1993 & na & na & daily & $1 \mathrm{r}$ & yes & yes & no & no & $\begin{array}{l}\text { road haulage, } \\
\text { tracking }\end{array}$ \\
\hline & is & Riyadh & state & 1982 & 250000 & 92 & daily & $\mathrm{g}, \mathrm{r}, \mathrm{f}$ & yes & 4 ha & yes & yes & $\begin{array}{l}\text { road haulage, } \\
\text { refrigerated storage }\end{array}$ \\
\hline & $z$ & Birgunj & private & 2005 & na & na & timetable & $4 \mathrm{r}$ & yes & yes & no & no & - \\
\hline & ڤ. & Faisalabad & private & 1994 & 40000 & na & daily & $4 \mathrm{r}, \mathrm{f}$ & yes & yes & no & no & - \\
\hline
\end{tabular}

D.Möller, University of Hamburg, presented at the convention "AlaSim" in March 2012 a simulation for Dryports. His theoretical results are focussed on throughput, waiting time, truck kilometer, cost analysis and eco-balance in comparison of a Dryport with a conventional port. 


\subsection{CONTAINER TERMINAL AND YARD SERVICES:}

The most found researches, related to container terminals, are focussing in cutting service time, improvements in operational processes on the basis of existing equipment. There are a lot of simulations for planning, storing, sorting, buffering and transferring of containers (see K.Alicke (2000). A newer simulation is focussing on an innovative technology for container terminal yard stacking system (N. Bornhöft et.al, University Hamburg, 2011). A.ASef-Vaziri ( Assistant Prof. Dep. of Systems and operation management, College of Business and Economies, California State University, Northridge and B.Khoshnevis (Professor, Dep. of Industrial and System engineering, University of southern Califonia, Los Angeles) have developed at the beginning of last decade a simulation model for automated storage and for automated guided vehicle system ( AGV ). Their simulation result shows an improvement of throughput by $375 \%$ vs. current manpowered moves and an AGV-utilization, which is $14 \%$ higher than the man-guided vehicle. Jeffery Karafa \&Mihalis, M.Golias, presented at the 53rd Annual Transportation Research Forum Tampa in March 2012, a simulation model for evaluation of intermodal marine container terminal gates. They are focusing on different gate strategies in the loading process of trucks and the reduction of delay. Their results show, that extended hours outperform appointment lanes and that a simulation must include the entire roadway network to give indications. The most integrated research was made in 2012 by Joachim Daduna. He designed a theoretical model without detailed aspects, in 
which he is transfering the containers with shuttles directly from the yard to a nearby satellite terminal and is either storing or loading to trains. In the book ( Container Terminals and Automated transport systems, H-O.Günther, Kap Hwan Kim, Springer Verlag ), there are reported simulations of sequencing of loading and stacking of containers in the yard. Sönke Hartmann, in the same book, is considering the scheduling of the port equipment like QC, AGV, Straddle carrier and their optimization. All of these simulations are based on a traditional port layout. A lot of micro movements within the nearest harbor region takes place. In Hamburg i.e., there are about 180 small truck carrier companies and about 220 railway carriers operating ( see Hafenentwicklungsplan 2025, HPA 2012 ).

There is no research or simulation found, which is includes the entire logistic chain from producer to the final customer and link the different process steps together. 


\section{$\&+\$ 37(5 \square \square$ \\ $02^{\prime}$ ( / प ( 9 ( / 230 ( $17 \square$}

In chapter 1.1.2 Figure 3 is described, how a traditional typical harbor layout is designed. There is a big stacking area in the yard for intermediate storing of the containers. This causes a certain staytime and a multiple movement and handling of the containers. The basic idea is to eliminate the intermediate storing, stacking and the multiple handling of the containers by immediate transportation out of the yard ( similar to the Dryport principle ) to different distribution centers ( train station, satellites, feeder collection area ), related to the given modal split. In these transfer-centers, there is planned a direct shipping to the customers, without storing and warehousing is planned. In Figure 15 the principle layout for the model is shown. For this idea a simulation model will be developed. 


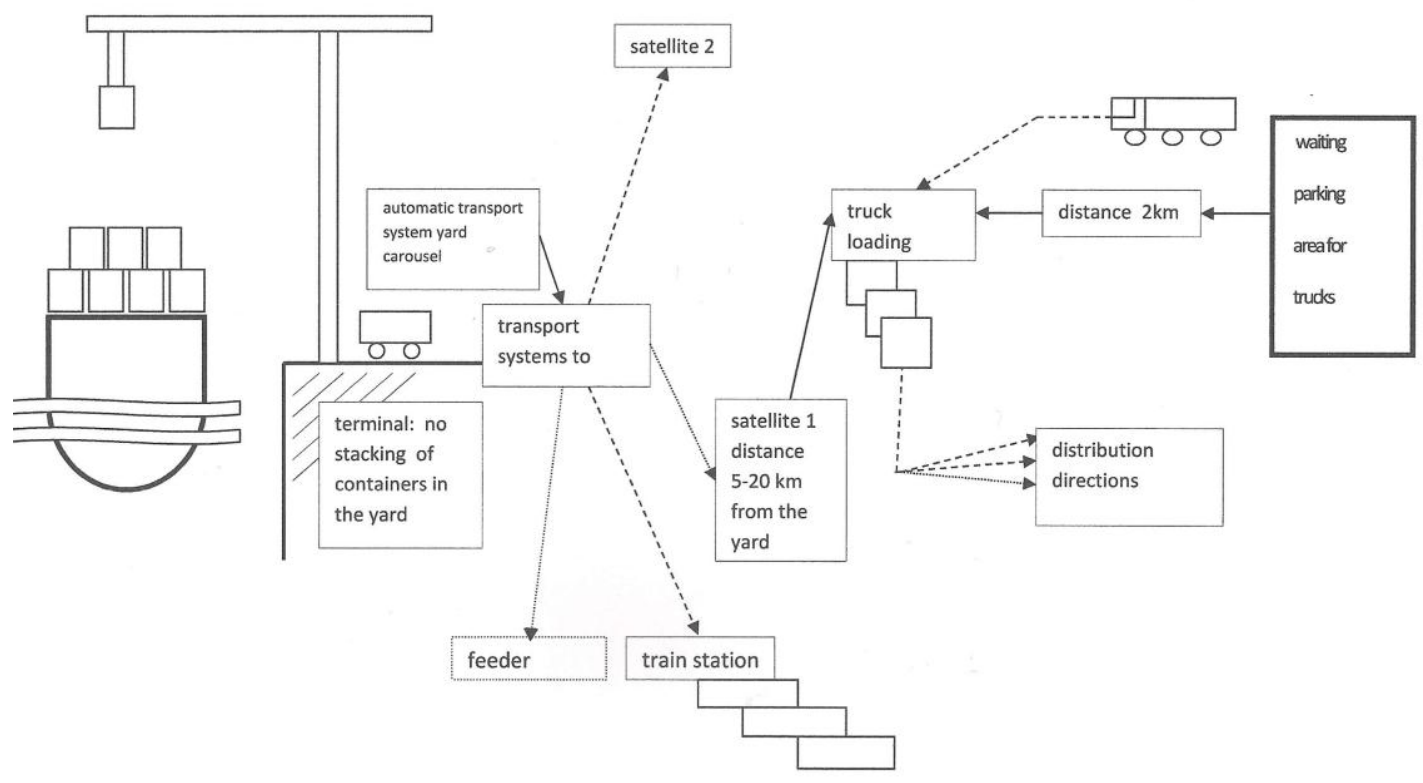

Figure 15 : Basic idea of the layout for the model

\subsection{ELEMENTS OF THE MODEL}

In the model there is only one type of container considered, a 40 feet container, which is equal to 2 TEU. Further there are considered only full loaded trains ( incoming and outgoing ). The unloading process chain from the trucks is simplified as a source without detailed process steps, like it is in the loading process applied, to avoid an overloading of the model. 


\subsubsection{Bill of Loading - incoming containers.}

In the Bill of Loading ( BoL ), each container has an individual number, which is related to the intermodal address ( see later: feeder, Satellite 1, Satellite 2, train). There is no loading sequence of the containers necessary, they can follow in a random row. But here is a high potential of gaining productivity if there is an optimization of loading sequence, related to the intermodal address. This is not considered in this model. Each bill of loading has a content of 5000 containers ( equal to 10000 TEU ) and is related to one ship. In the model there are choosen two ships, operated at the same time (loading and unloading ) and a modal split of :

- $10 \%$ feeder

- $70 \%$ trucks ( in 2 satellites )

- $20 \%$ trains ( in 5 lines)

The individual container number is linked to the modalsplit destination ( see figure 16). 


\begin{tabular}{|c|c|c|c|c|}
\hline Container No. Ziel & LKW No. & LKW ID / Zug ID & Kundenkreis & \\
\hline 1 & 4 & & & \\
\hline 2 & 4 & & & \\
\hline 3 & 4 & & & \\
\hline 4 & 4 & & & \\
\hline 5 & 4 & & & \\
\hline 6 & 4 & & & \\
\hline 7 & 4 & & & \\
\hline 8 & 4 & & & \\
\hline 500 & 4 & & & \\
\hline 501 & 3 LKW_501 & 501 & 1 & \\
\hline 502 & 3 LKW_502 & 502 & 1 & \\
\hline 503 & 3 LKW_503 & 503 & 1 & \\
\hline 504 & 3 LKW_504 & 504 & 1 & \\
\hline 974 & 3 LKW_974 & 974 & 1 & \\
\hline 975 & 3 LKW_975 & 975 & 2 & \\
\hline 2250 & 3 LKW_2250 & 2250 & 2 & \\
\hline 2251 & 2 LKW_2251 & 2251 & 1 & \\
\hline 2252 & 2 LKW_2252 & 2252 & 1 & \\
\hline 2253 & 2 LKW_2253 & 2253 & 1 & \\
\hline 2254 & 2 LKW_2254 & 2254 & 1 & . \\
\hline 2724 & 2 LKW_2724 & 2724 & 1 & \\
\hline 2725 & 2 LKW_2725 & 2725 & 2 & \\
\hline 4000 & 2 LKW_4000 & 4000 & 2 & \\
\hline 4001 & 1 & 1 & & \\
\hline 4100 & 1 & 1 & & \\
\hline 4101 & 1 & 2 & Ziel & 4 Feeder \\
\hline 4200 & 1 & 2 & & \begin{tabular}{l|l}
3 & Satellit1 \\
\end{tabular} \\
\hline 4300 & 1 & 3 & & 2 Satellit2 \\
\hline 4301 & 1 & 4 & & $1 /$ Zug \\
\hline 4400 & 1 & 4 & & \\
\hline 4401 & 1 & 5 & Kundenkreis & 1 Tageslieferungen 8-16 \\
\hline 4499 & 1 & 5 & & 224 h Lieferung \\
\hline 4500 & 1 & 5 & & \\
\hline 4501 & 1 & 6 & & \\
\hline 4600 & 1 & 6 & & \\
\hline 4601 & 1 & 7 & & \\
\hline 4700 & 1 & 7 & & \\
\hline 4701 & 1 & 8 & & \\
\hline 4800 & 1 & 8 & & \\
\hline 4801 & 1 & 9 & & \\
\hline 4900 & 1 & 9 & & \\
\hline 4901 & 1 & 10 & & \\
\hline 5000 & 1 & 10 & & \\
\hline
\end{tabular}

Figure 16 : Bill of Loading ( BoL ) 
Explanation of the bill of loading (for ship 1 ; for ship 2 similar 5001-10000):

$\begin{array}{ll}\text { column 1: } & \text { Container number } \\ & 1 \ldots \ldots .500: \text { feeder } \\ & 501 \ldots . .2250: \text { truck ( satellite } 1) \\ & 2251 \ldots . .4000: \text { truck ( satellite } 2) \\ & 4001 \ldots . .5000: \text { train }\end{array}$

column 2; modalsplit target

4: $\quad$ feeder

3: $\quad$ Satellite 1

2: $\quad$ Satellite 2

1: $\quad$ train

column3: $\quad$ truck number (is identical with container number) ( for feeder or train no need )

column 4: $\quad$ truck ID : $\quad 501 \ldots . . .4000$

train ID : $\quad 1 \ldots . .10$ 
column5:

customer distinction in picking up the containers

$$
\begin{aligned}
& \text { truck } 501 \ldots 974 \text { : } 8 \text { hour window } \\
& 275 \ldots 2250: 24 \text { hour window } \\
& \text { 2251.. } 2724: 8 \text { hour window } \\
& 2725 \ldots 4000: 24 \text { hour window } \\
& \text { train: } 4001 \ldots 4100: 2 \text { trains long distance. } \\
& \text { destination east dryport } \\
& \text { 4101...4200 : } 2 \text { trains long distance } \\
& \text { destination East-East dryport } \\
& \text { 4201...4500 : } 6 \text { trains: south dryport } \\
& 4501 \ldots 4800 \text { : } 6 \text { trains: southeast dryport } \\
& \text { 4801...5000 : } 4 \text { trains: southwest dryport }
\end{aligned}
$$

The advantage of the model is, that the bill of loading can be changed easily in

- modal split

- number of containers

- final customer stations

- time frame for services.

- $\quad$ special treatment (customs or other inspections)

There is full flexibility to cover nearly every case of containers transportation chain. 


\subsubsection{Quay Crane}

The QC is transporting the container from the vessel to the yard and reverse. There is a traditional type of QC with one trolley considered. After a certain period ( in the model two hours was selected ), the QC is starting with a simultaneous unloading loading process which cut the cycle-time nearly by half or double the usage. The assumption is, that after two hours a compartement in the vessel is fully unloaded and the loading process can start in parallel. The traditional QC has a uniform distribution of 30 to 90 seconds. A number of studies were made to improve the efficiency of QC. The major projects and concepts are double pick up of containers ( already in place at CTATerminal Hamburg, a pilot demonstation system of the Chinese company ZPMC near Shanghai ), driverless QC (faster acceleration of the trolley possible than man-guided) using lift systems and double trolley to cut lifting time.

A very good overview about all these technologies are provided in the article " New conceptual handling systems in container terminals”, Kap Hwan Kimet.al, Industrial Engineering \& management Systems, Vol 11, No 4 , 2012, pp 299-309.

\subsection{3: Yard transportation system}

Most of the research is done in optimization and accelaration of yard stacking. But this does not meet future requirements. The market growth of container logistics and the increase of the capacity of the vessels up to 22000 TEU require a higher throughput capacity in the yards of the hub ports. All improvements in QC, yard equipment and 
stacking methods does not solve the major problem of the traffic hotspot in the yard. The yard areas are limited and cannot be increased infinitely.

The idea of the proposed model is to transfer the containers immediately from the QC to an intermediate destination in a certain distance from the yard and spread the traffic to the Hinterland. Therefore a carrousel system along the quay is built, on which the containers can be loaded. The carrousel has four exits on which the containers can be guided to their dedicated intermediate destination refered to the modalsplit (see BoL). The stacking in the yard is reduced to a minimum ( feeder collection). The same carrousel is used for the loading process. The containers are coming on the same transportation systems from feeder, satellites, and train to the carrousel with dedicated destinations, i.e. QC (1...5) for the 1 st vessel or OC $(6 \ldots . .10)$ for the 2 nd vessel. The labeling can be done by barcode or RFID. In front of each QC is a small buffer for the containers to be loaded.

The carrousel system could be

- a belt system

- AGV system

- chain connected chassis system

- overhead grid rail system

- Speedport by ACTA Maritime

(Development Corporation, New York (see http://www.actamarine.com))

It seems that a carrousel system is a feasible design for the yard. 


\subsection{4: Transportation system to Satellites}

The satellites should be located in a distance of 5 to $15 \mathrm{~km}$ from the yard in different directions to manage the truck-traffic. Satellites serve mainly the trucks. The transportation system should be able to have a continuous transport of the containers from the carrousel to the satellite ( and reverse for the loading process). There are several different possibilities under discussion:

- $\quad$ rail system ( drive by chain)

- overhead cable system

- tube system ( planetforward.org, D.Alba 2012, The GRID-project,Cargocab )

The speed can be varied as needed.

\subsubsection{The Satellite}

The Satellite can be considered functionally as a "Dryport" which will offer all kind of services such as :

- administration documents

- customs clearing

- $\quad$ special treatment ( hazardous contents)

- special inspection, quarantine

- $\quad$ shipping docks for truck

- buffering of containers

- empty container handling 
- collection of containers for the loading process of the vessel

- maintenance and clearing of containers

- parking area for trucks waiting to be loaded or unloaded

In the simulation model the satellite (Dryport) is coordinating and scheduling the Hinterland Logistic chain for the trucks. Of course the satellite can have access to railway system and can service trains as well. But this is not part of the model.

\subsection{6: Train-Railway station}

In the intermodal split, the transportation by railway becomes more and more important. Cost and pollution reduction are the main driving factors. With a distance of $500 \mathrm{~km}$ and more, the specific cost by train are about $40 \%$ lower and the $\mathrm{CO}_{2}$ - pollution with trains is only $25 \%$ of the pollution of truck transportation. The disadvantage of railway transportation is the overall timing, as from the train destination ( "Dryport" or GVZ), the final transport to the customer must normally be done by truck. All major harbors have plans to increase the train transport to Dryports. Normally the customs clearing and further Hinterland logistics are organized by the Dryports. Good examples of these train hubs are :

- Polzug from Hamburg to Poznan (Polen)

- train connection from Hamburg to Vienna (Austria)

- train connections to so called GVZ in South-and Middle Germany ex Hamburg or Rotterdam

- ICTF-hub in Long Beach (USA) 
Between Europe and USA the container transportation by train is quite different. The total train length in Europe at the moment is $750 \mathrm{~m}$ with plans to extend in some cases to $1000 \mathrm{~m}$. The total capacity of one train is therefore about 100 TEU or maybe in future 140 TEU. In USA the train lenght can easily be $1500 \mathrm{~m}$ and they can be double stacked and have capacity of 300 TEU or even more (see above mentioned study from Parson, in which 750 TEU are mentioned for a shuttle train). The railway station is served by a carrousel and three TC. In the model there are five lines in the railway station. Two lines are foreseen for very long distance destinations like Poland or Russia ( if we take Hamburg harbor as an example ). From each of these two lanes, two trains or coming and leaving with a loading /unloading time of four hours. The other three lines are for trains with shorter distance and with connection to Hinterland, Dryports, DCs or special customers. The loading time there for is about one hour per train. Each train needs 30 minutes to arrive at the railway station and to leave the railway station. The assumption is further, that each train is carrying containers, which need to be loaded onto the vessel. In the model, from each arriving train must be unloaded of three containers before the simultaneous loading /unloading process can start. Improvements of the crane capacity or crane system are not considered, but can easily be integrated in the model by changing cycle time.

\subsubsection{Feeder}

Feeders are smaller vessels that make the logistic connections from the hub harbor (i.e. Hamburg, Rotterdam ) to smaller ports, i.e. ports in Scandinavia and Baltic Sea or to 
riverports like Duisburg. The feeders normally are not loaded simultaneously as they collect containers from different vessels and different yards. The feeder volume is considered in the model as a sink. In the new terminal in Rotterdam, it is possible to have the berth for the feeder directly beneath the container vessel, so the containers can be placed, without additional handling, directly on the feeder. This is mainly used, if the carrier of the container vessel and the carrier of the feeder is the same company.

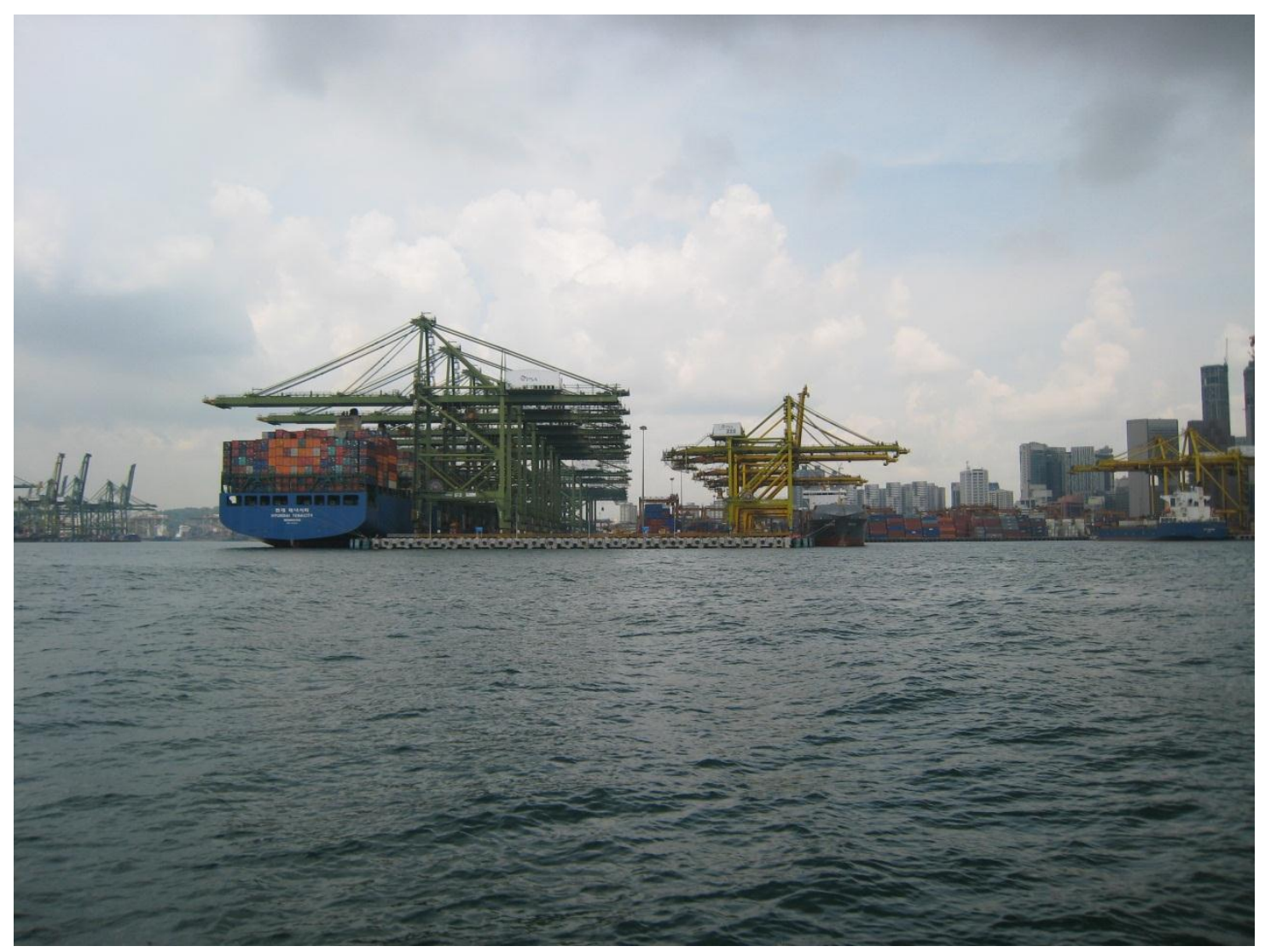

Figure 17 : Example of parallel loading/unloading process between vessel ( left ) and Feeder ( right side ) at the same berth ( own picture in the port of Singapore ) 


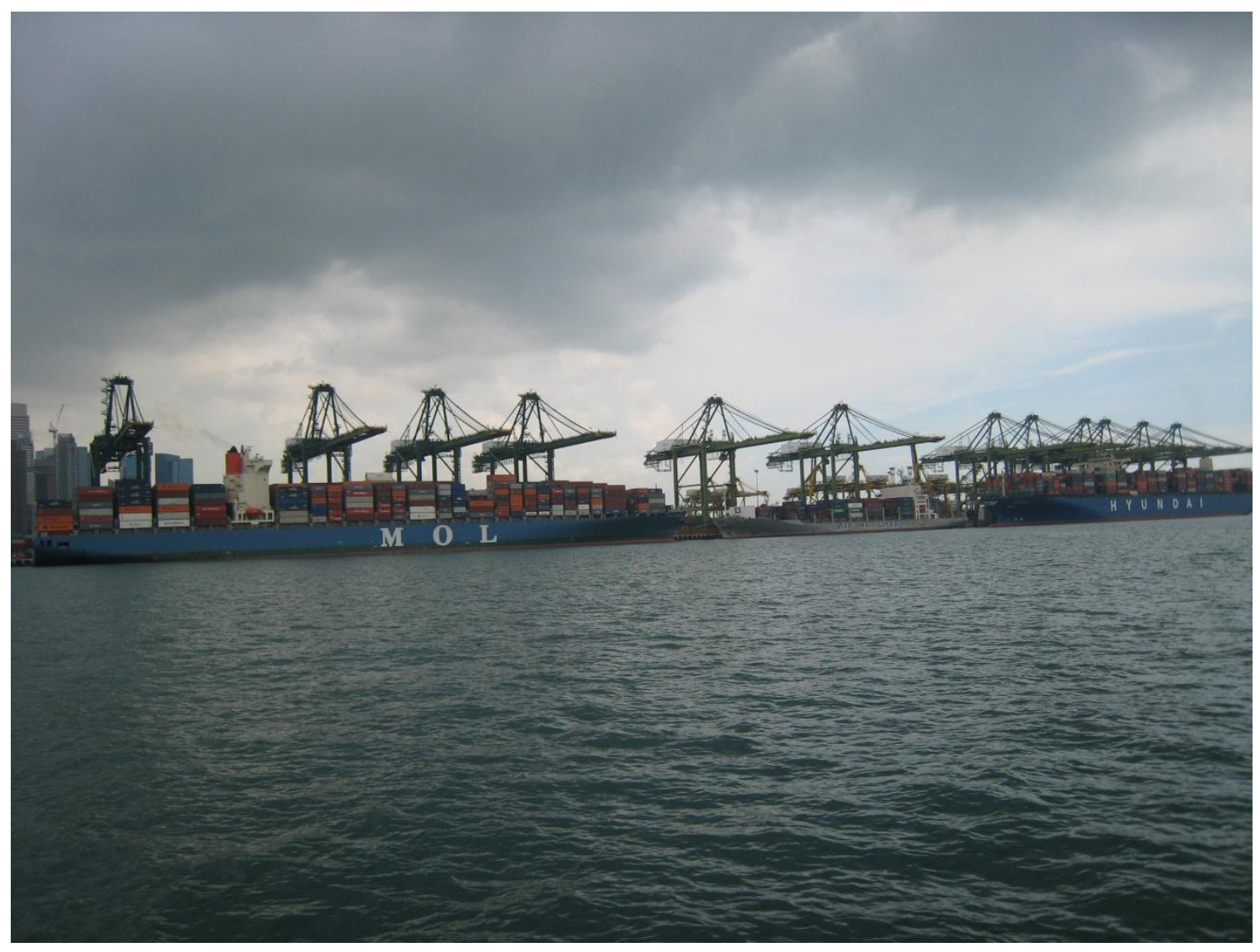

Figure 18 : Example of loading/unloading process of a feeder (middle ) serving 2 vessels at the same berth side. Containers are moved along the berth ( own foto in the port of Singapore )

The port of Singapore has a high portion of feeder transport in the modalsplit ( > 90\% ). The two examples show, that they have already reached a high efficiency of throughput in the yard ( see chapter 1.1.2). Improvements are possible with shorter cycletime of the QC's and the move between the vessels and the feeder. In other ports ( Hamburg, Rotterdam ), feeders must collect their containers from several different berths, which cost a lot of time. The feeder processes have different constraints and are not considered in the model. 


\subsubsection{Bill of Loading for collected containers for export (loading process).}

As already explained, the model shows a simultaneous unloading / loading of the vessel. Therefore it is assumed, that the trains and the trucks are transporting the containers to their transportation system (satellite or train-station). The containers are carrying numbers from 10001 to 20000. Each ship is divided in five compartments, related to the five cranes. For two ships there are ten compartments with numbers 1 to 10. So each container is addressed to the dedicated compartment, which can be related to the next destinations (harbors) of the vessel. Each compartment has 1000 containers. The containers are sent by truck, train or feeder. The structure and the split can be changed easily. The model requires a high grade of organization, as the sequence of loading must consider the weight distribution of the vessel, the part of empty containers ( which can reach up to $30 \%$ and more ) and different destinations. This is not included in the model.

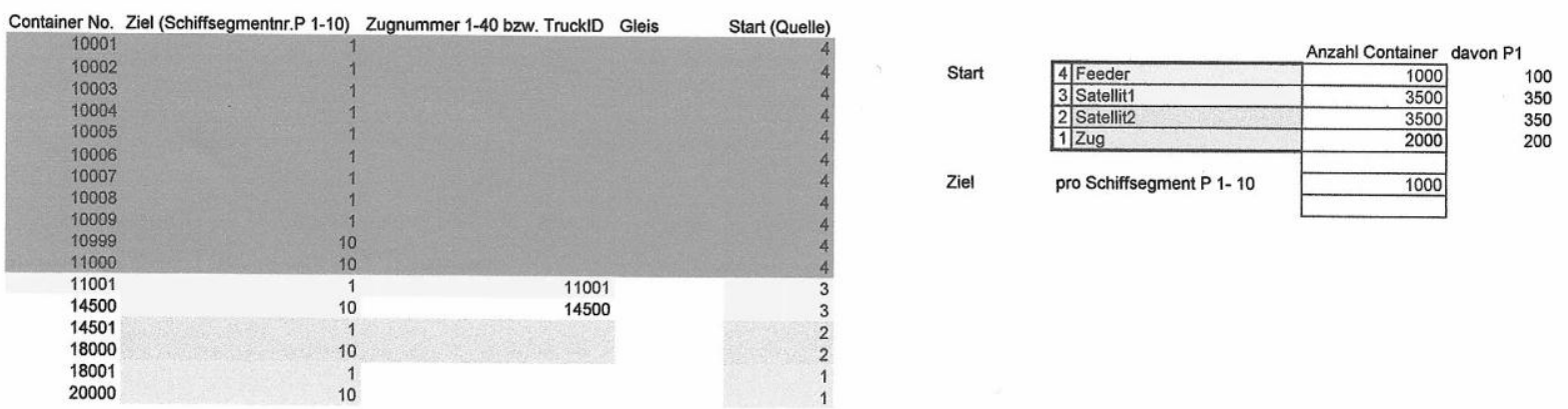

Figure 19 : Bill of Loading for export (loading process of the vessel ) 


\subsection{FLOW-CHART OF THE LOGISTIC CHAIN FROM CONTAINERSPHIP TO HINTERLAND}

\subsubsection{Flow chart harbour:}

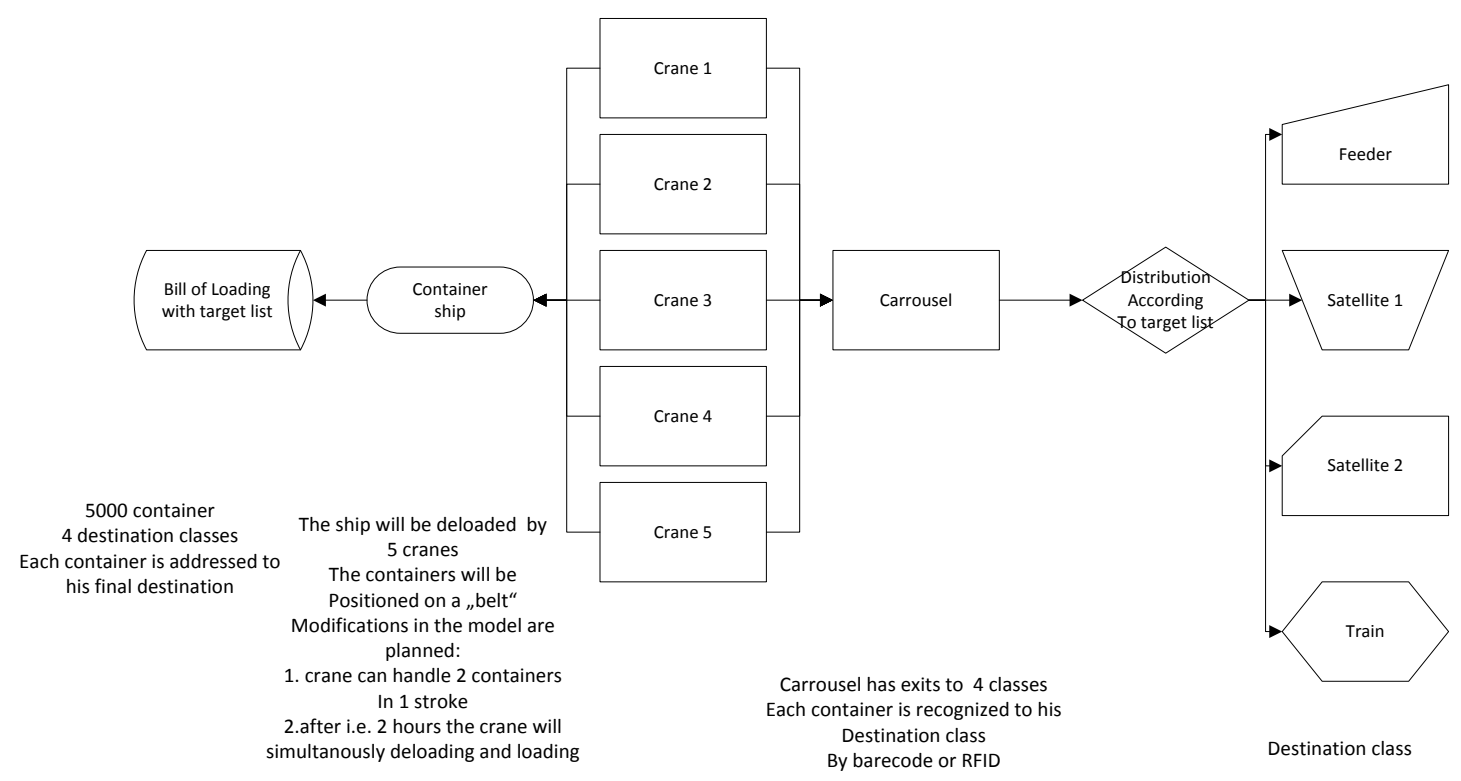

Figure 20 : Flowchart container from vessel 1 to carrousel exits. ( vessel 2, the BoL and cranes 6-10, serving the same carrousel, are not shown in the principle drawing to keep the overview simpler, but is part of the model )

The flowchart shows the general structure for one vessel with 5000 containers for unloading and 5000 containers for loading. In the model there are two vessels being operated in parallel. Each QC has to load and unload 1000 containers. The containers are placed directly to the carrousel. Relating to their destination, marked by RFID or barcode, 
the containers leave the carrousel at foreseen switchpoints ( feeder, satellite1, satellite 2, train ). For containers to be loaded onto the vessel, in front of each QC, is a buffer switch for 3 containers, to make sure, that there is always a container available for the simultaneous unloading / loading process. There are different possible variations in the model such as

- cycle time of QC

- $\quad$ speed of the carrousel

- length of the carrousel

The flowchart does not show the reverse process for loading the ship, which is analog.

\subsubsection{Flow chart Satellite}

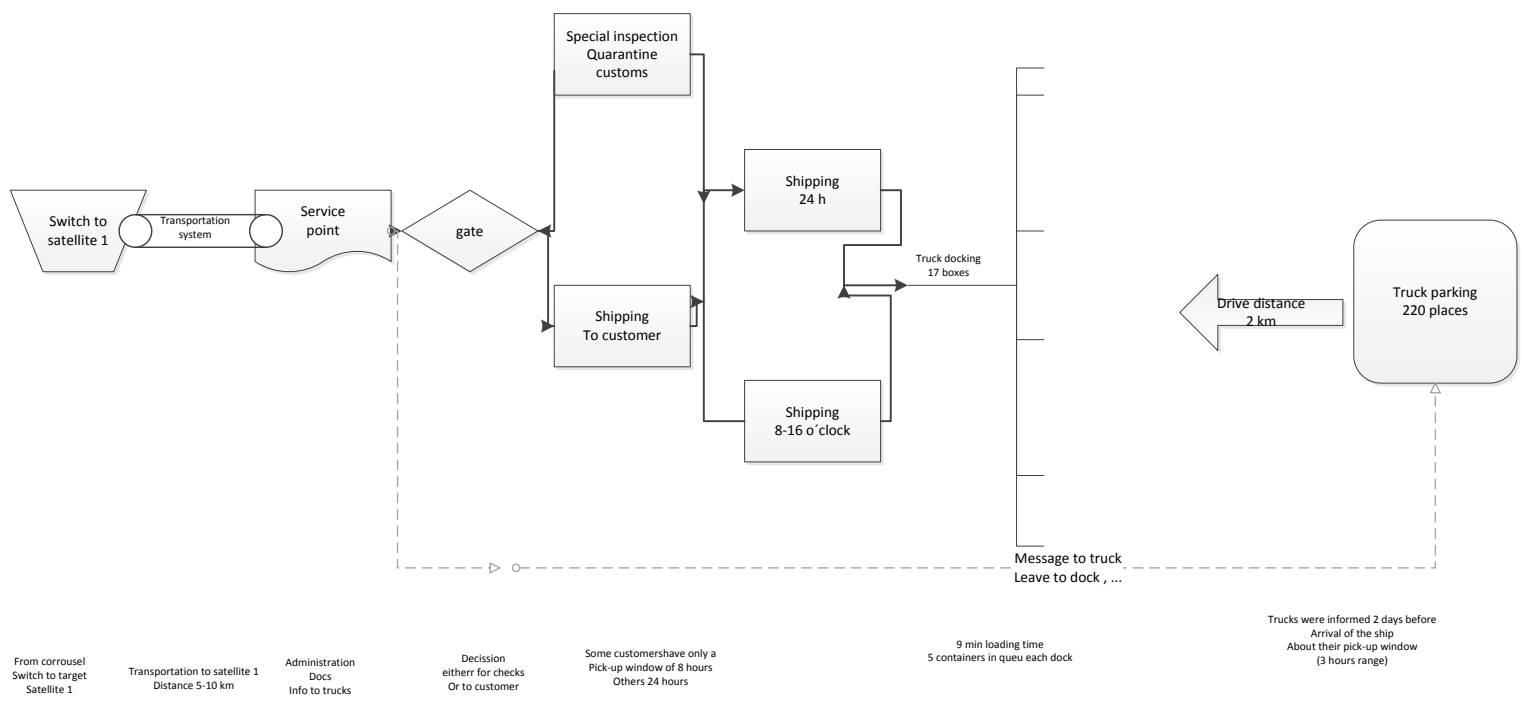

Figure 21 : Flow chart satellite-truck loading 
In the model there is considered only one satellite considered as the other processes will be equal and in parallel, so one satellite has no impact on the other. During the travel time from the quay carrousel to the satellite, there is enough time for preparation of the adminstration documents and messaging the truck drivers for pick-up time. It is assumed, that $10 \%$ of the containers have to pass a special inspection by the authorities ( customs, veterinary ), which means a delay for further shipping by up to eight hours. Most of these delays are known in advance and can be rescheduled. The other $90 \%$ can pass for shipping to the truck docking boxes. For $20 \%$ of these containers there is only an eight hour shipping window, so there is a need for buffering. All these percentage assumptions can easily be varied. The truck carriers get on early probable arrival date of the vessel, so they can schedule their trucks within a window of 24 hours at approximately 10 to 15 days before arrival. Two days before arrival of the vessel the truck carriers get their final forecasted pick-up window in a range of three hours. This assumption for scheduling is related to JIT-supply in the Automotive Industry and is quite realistic. The trucks must arrive at the beginning of this three hour range in the parking area, which is about $2 \mathrm{~km}$ distance from the docking station. When the container arrives at the service point and the shipping docs are cleared, the truck driver get the final message to pick up his container. At each docking station there are five containers in queue, with a loading time of nine minutes each, so there is enough time for the truck driver to be in time. In reality, this process needs a very reliable micromanagement of scheduling and troubleshooting for disturbances. There must be a central coordination of all carriers and all processes in the harbor. 


\subsubsection{Flow-chart train:}

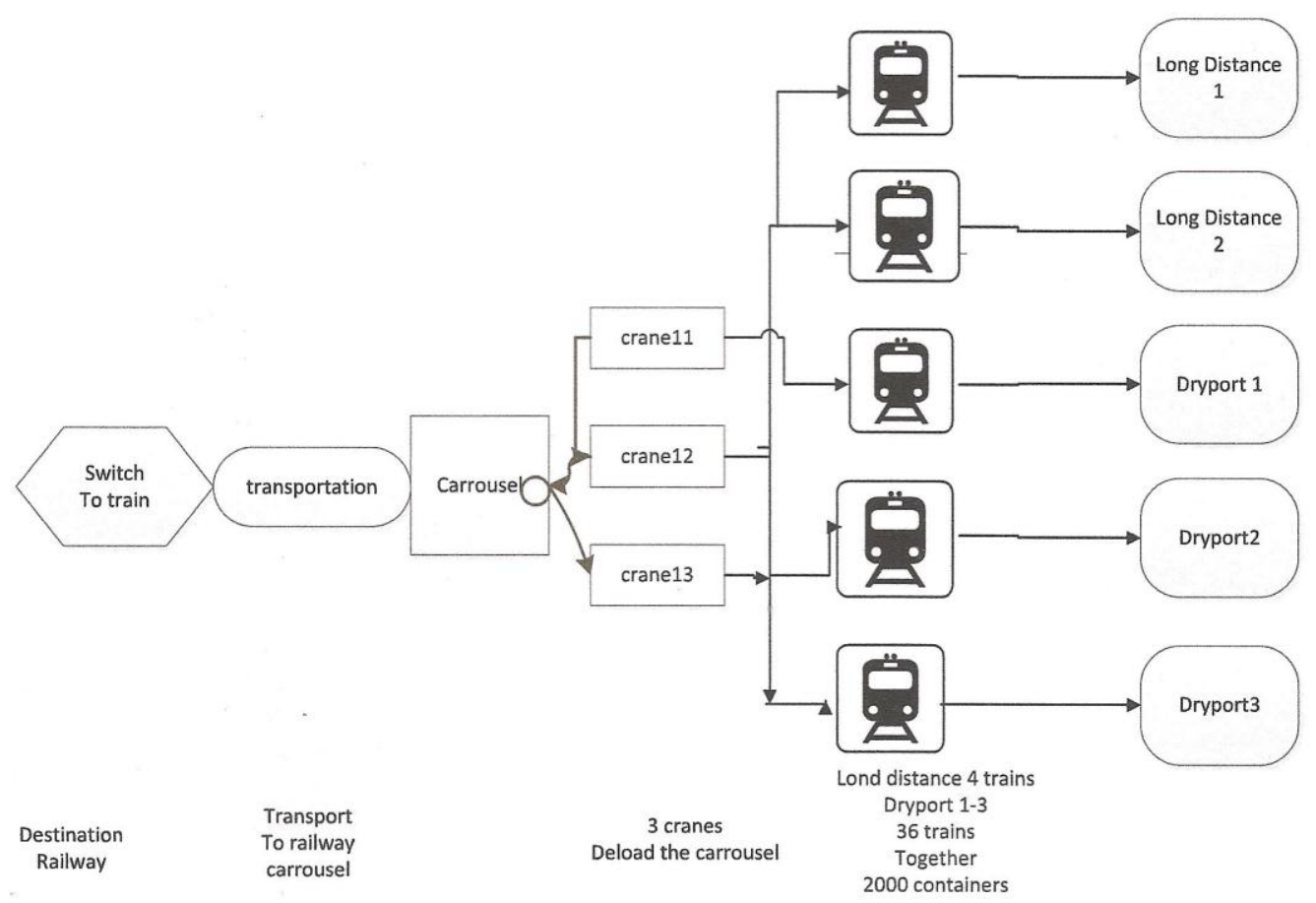

Figure 22 : Flow chart train loading

For the railway transportation to long distance destinations and Dryports, there is only a simple registration and identification of the sealed containers foreseen, so customs clearing is done at the final train destination. In the model a carrousel is planned, which is linked to three TCs. For 2000 containers (1000 from each vessel), there are 40 trains necessary. It is assumed that the 40 trains are available in time. 


\subsection{SCOPE OF THE MODEL}

The major scope of the proposed model is, to consider the entire logistic chain of the container transportation, from loading the container onto the vessel until shipment to the customer. The challenge is, to master and control all existing interfaces during the processes. This needs a single organization point to direct and to manage all the players. Existing research of today is always considering segments of the process chain, which is in reality not a chain, because there are a lot of buffers, warehousing, stacking and multiple handling. Therfore the focus of the proposed research is as followed:

- how to cut the cycle time of QC

- how to accelerate the loading / unloading process of the vessel

- how to eliminate the stacking process

- how to minimize the loading time of the trucks

- how to optimize the mega-hub of a Dryport

- how to minimize emission and pollution

None of the existing research efforts considers a model for the complete real chain with the necessary interfaces and a minimum of handling processes and a minimum of throughput time. The proposed model shall show the potential of total integration of all 
processes and interfaces to a real logistic chain, like a string of pearls. The gaps in existing models are such irregularities as the following:

- failures in the BoL

- longer break - down of equipment

- damaged containers

- uncertainties of container content

- lost declaration labels ( RFID )

- traffic problems ( accidents )

- different interests of the players which pretend a single coordination

The proposed research will address these shortcomings.

The proposed model has the following fundamental processes :

- continuous flow of the containers

- no stacking in the yard

- no double handling of containers, i.e. no intermediate storing

- fully automated transportation systems with manless transportation units

- interlinked transportation systems

- parallel unloading/loading processes of ships 


\subsection{THE PROPOSED MODEL}

The proposed model is designed with the simulation software "Enterprise Dynamics" from Incontrol Simulation B.V, Utrecht NL and is shown in the figures 23-36 below. This model will seek to correct the difficulties cited above for existing simulation models.

\subsubsection{Major equipment elements in the model}

- 2 container ships

- $\quad$ Quay cranes $(\mathrm{QC})$ for parallel loading and unloading process

- $\quad$ Loading buffers in front of each QC

- Yard transportation carrousel used for unloaded and loaded containers

- four junctions to train station, satellite 1 , satellite 2 sink, feeder sink

- Transportation system to train station, satellite 1 , satellite 2 sink, feeder sink

- Train station transportation carrousel

- $\quad$ Loading buffer in front of each train crane (TC)

- $\quad$ Train cranes (TC) for parallel loading/unloading process

- $\quad$ Rail tracks

- $\quad$ Administration desk in satellite 1

- Quarantene buffer

- Service buffer for limited supply time

- $\quad$ Truck docking station for the unloaded containers with buffer

- $\quad$ Truck waiting area

- Sources for containers to be loaded 


\subsubsection{Model Tree}

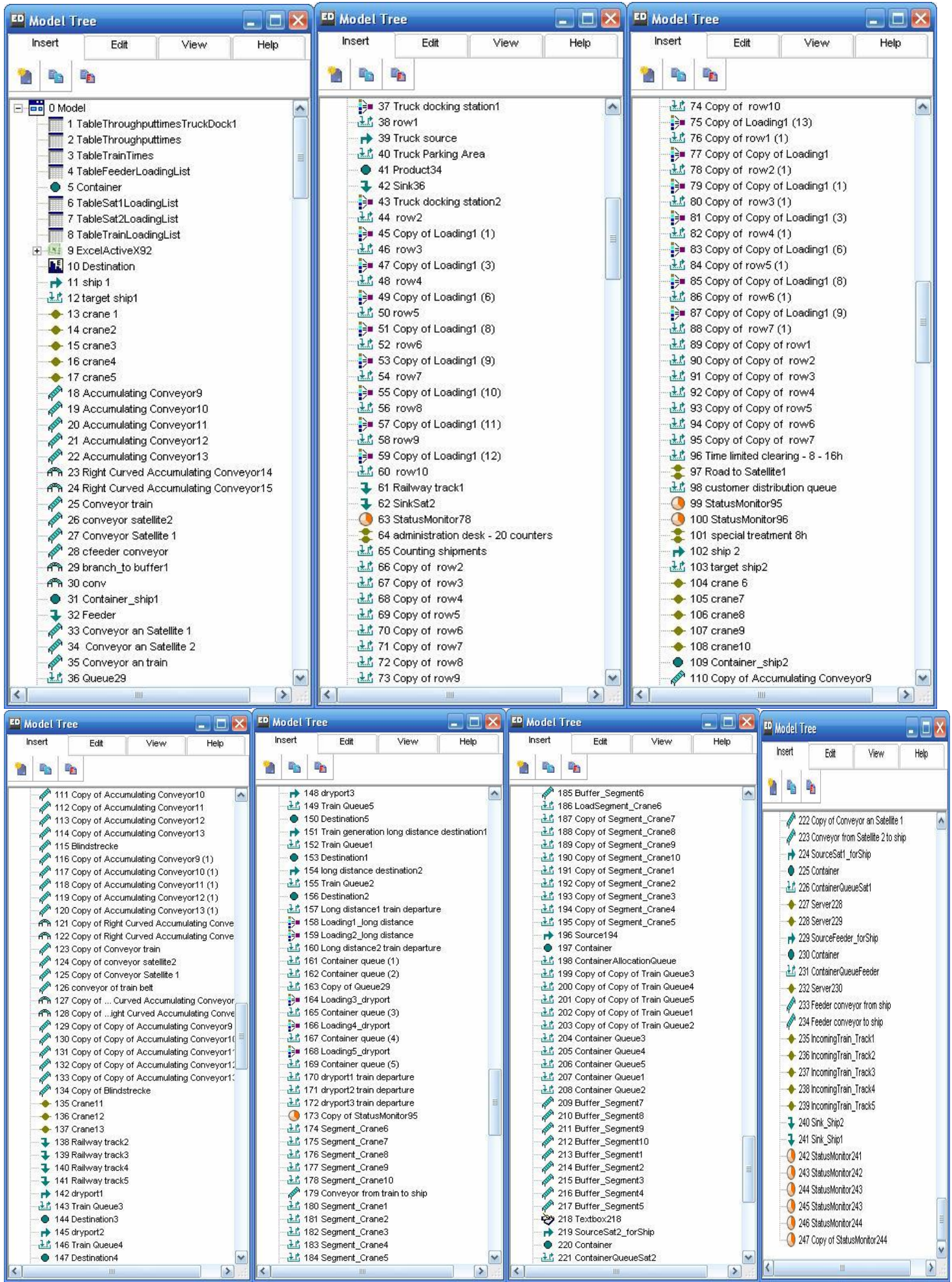

Figure 23 : Model tree 


\subsubsection{Overview about the model with major areas}

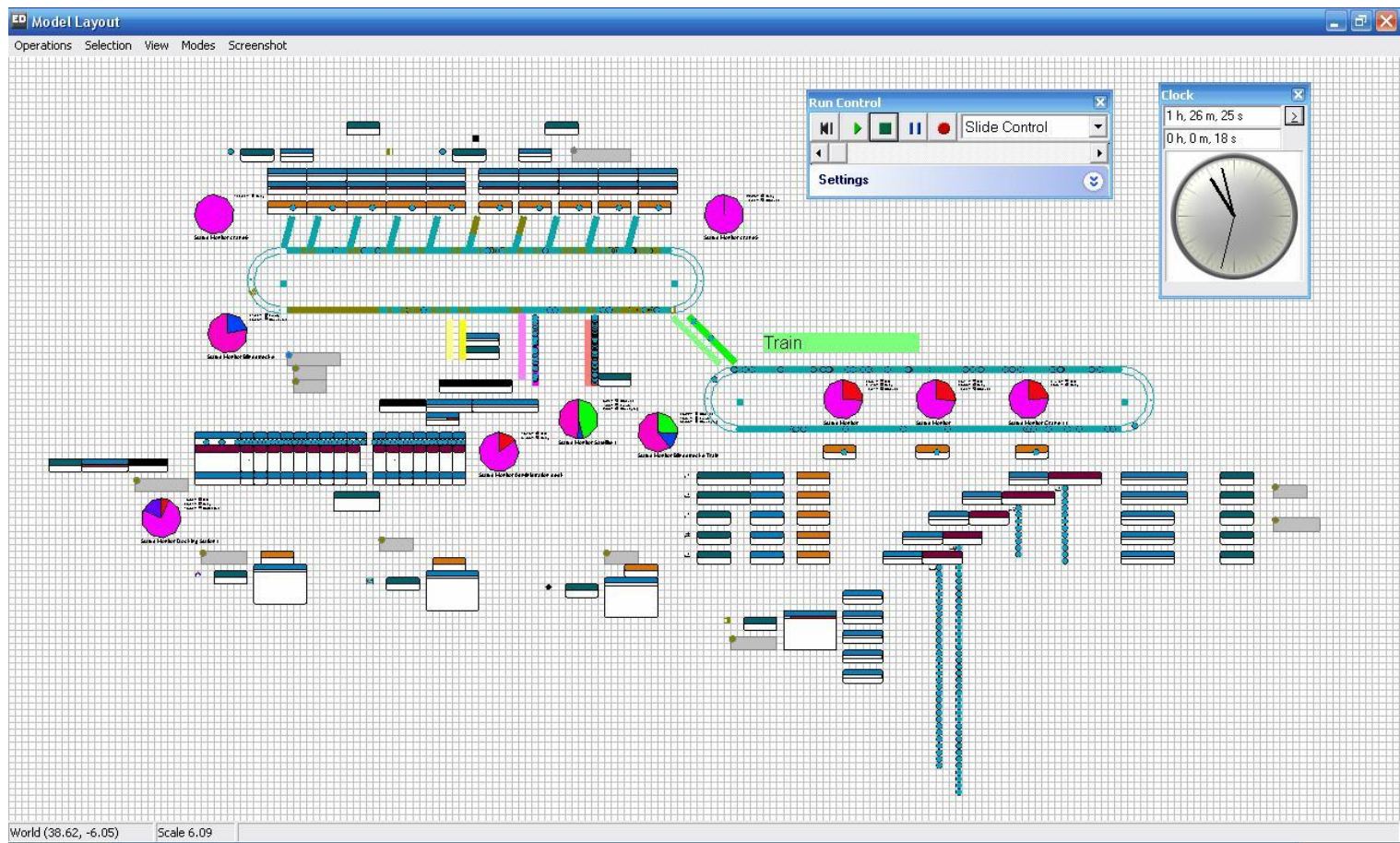

Figure 24 : Overview of the model layout with vessel, QC, carrousel, distribution nodes for feeder, Satellites, train 


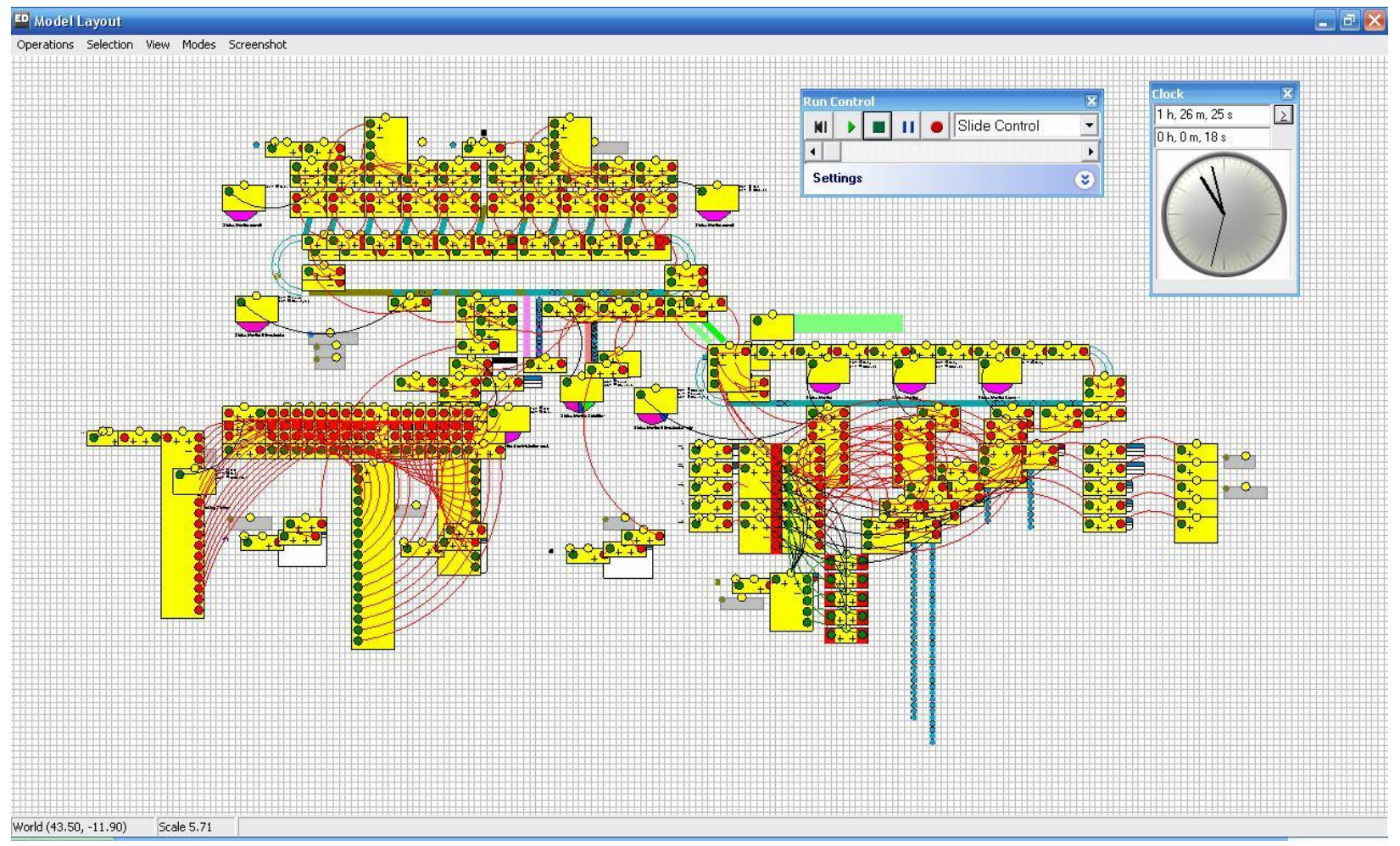

Figure 25 : Simulation model with all channel-connections of the elements 


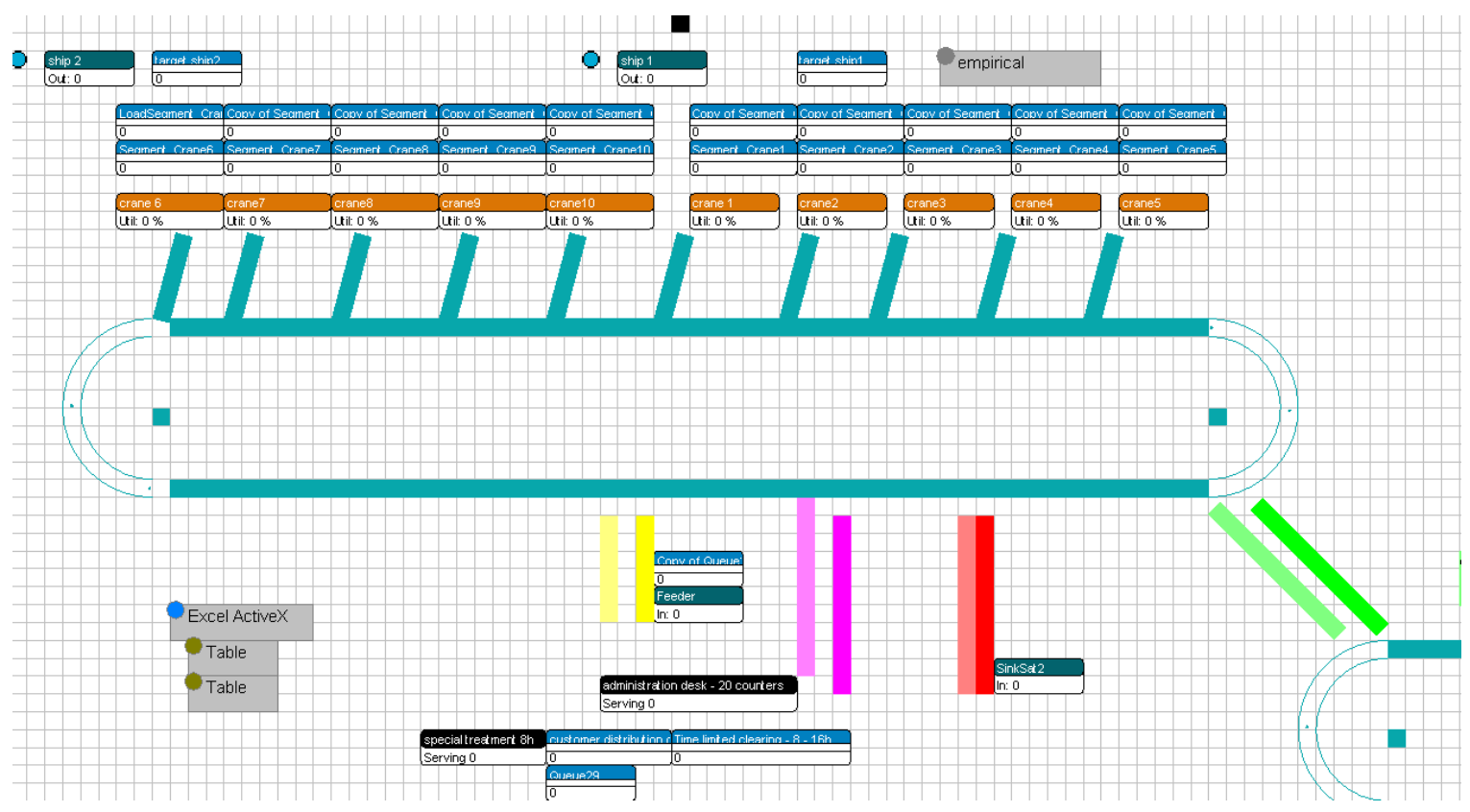

Figure 26 : Model for the yard with QC and carrousel

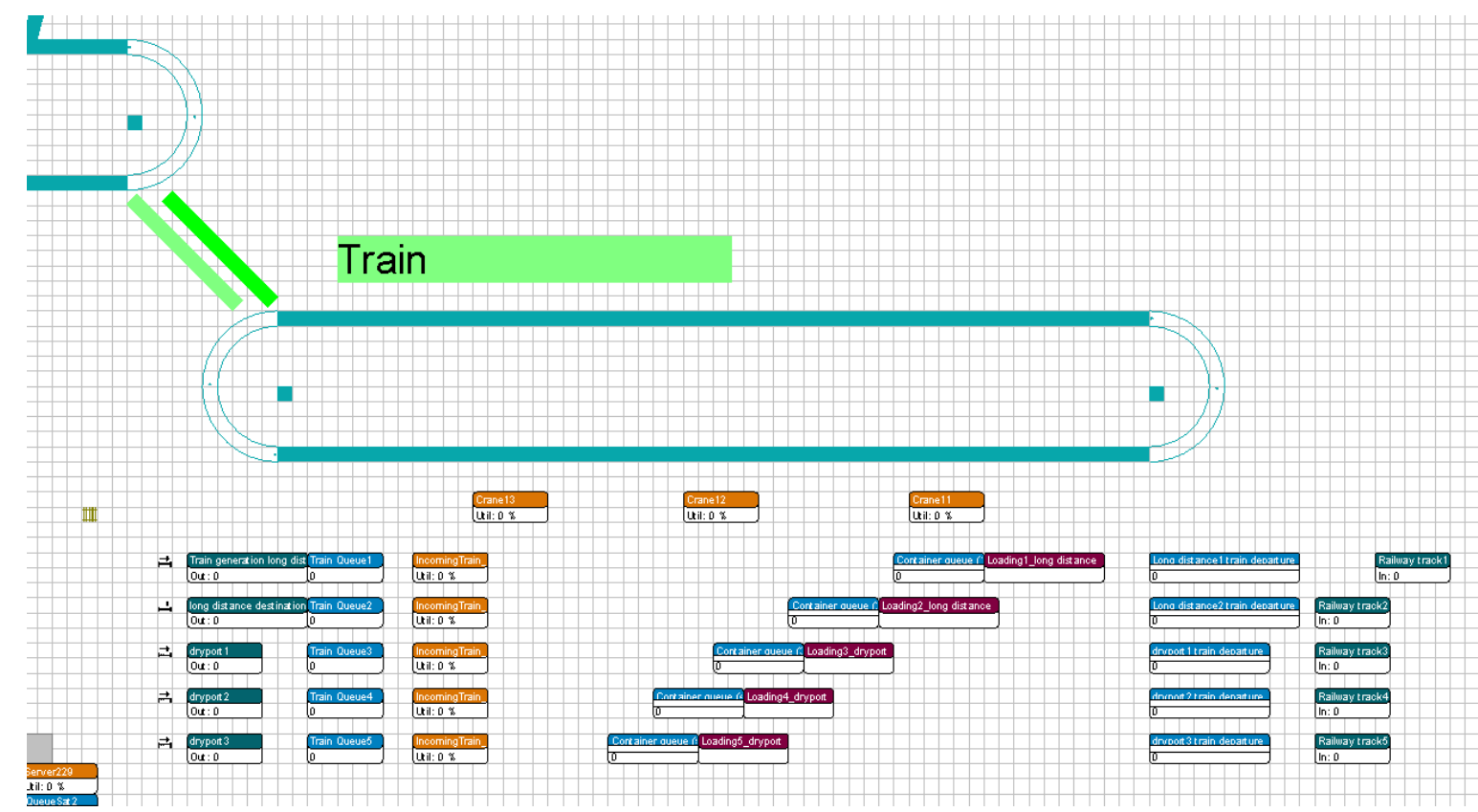

Figure 27: Model of the train loading area 


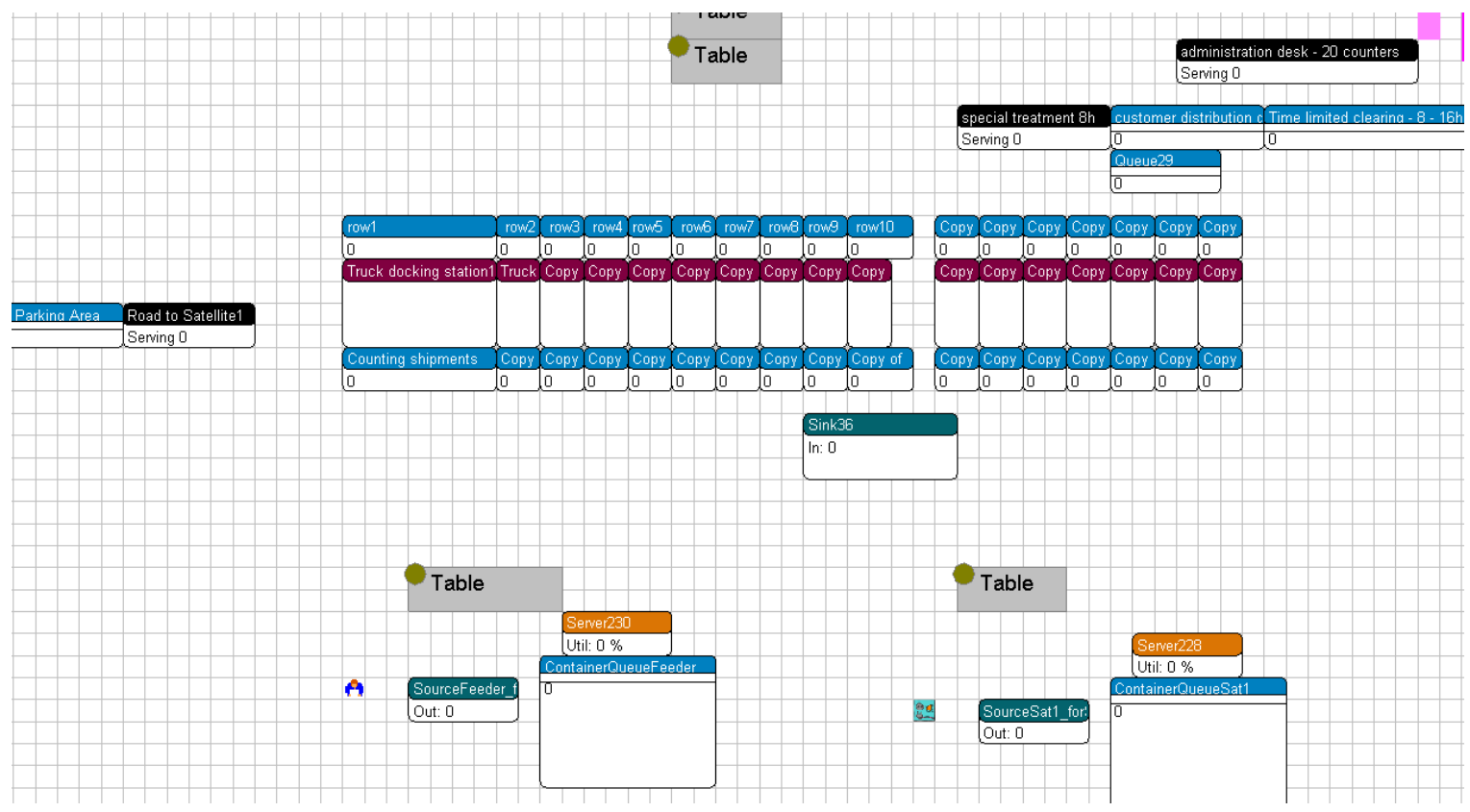

Figure 28 : Model of the satellite with truck loading area 


\subsubsection{Examples of programing, controling, reporting and experimental elements}

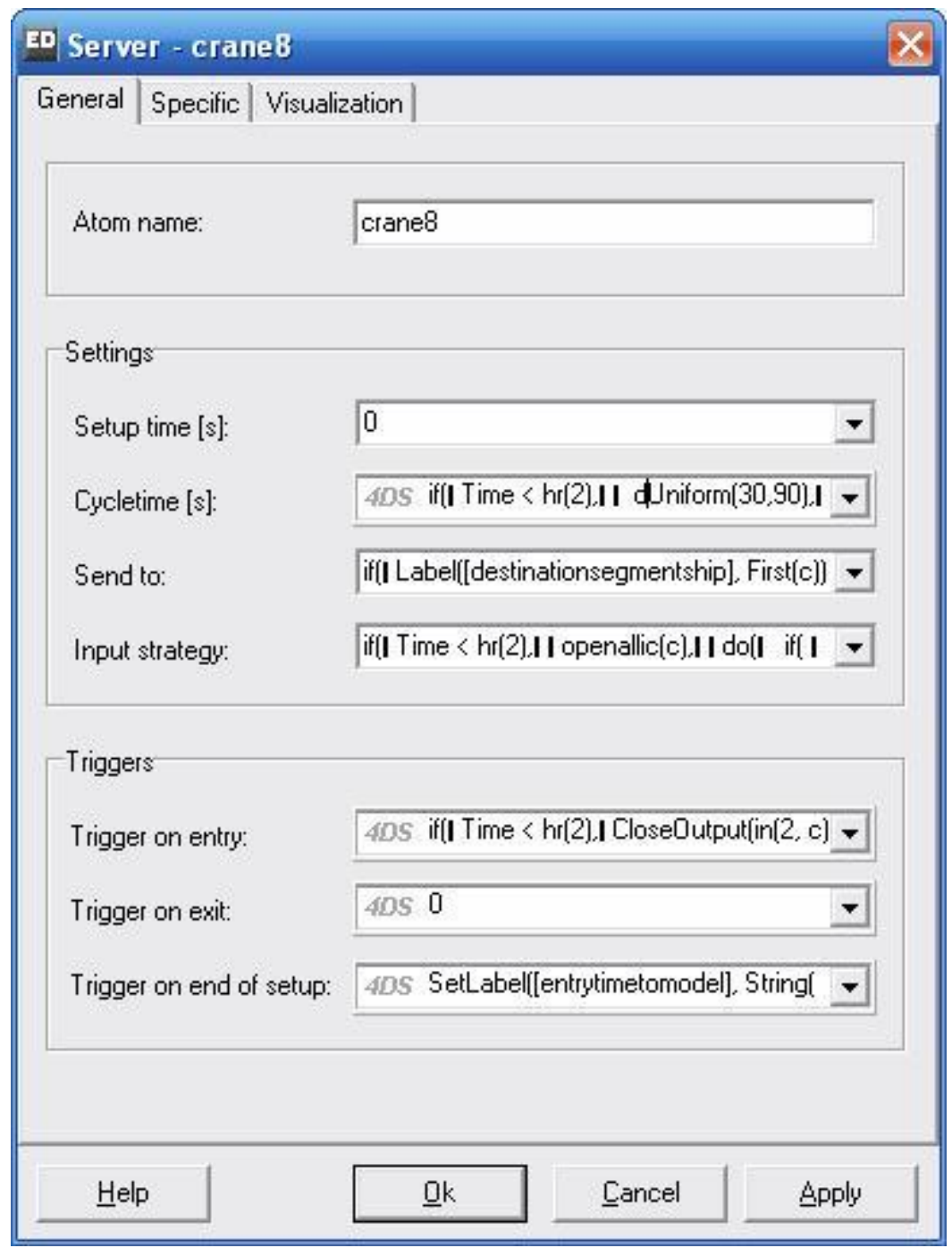

Figure 29: Example for a atom general : server crane 8, important : cycle time uniform distribution between 30 and 90 seconds if time is $<2$ hours

The programing allows all kind of statistical processes and distribution of relevant values such as cycletime etc. and other input values ( s.figure 29 ). 


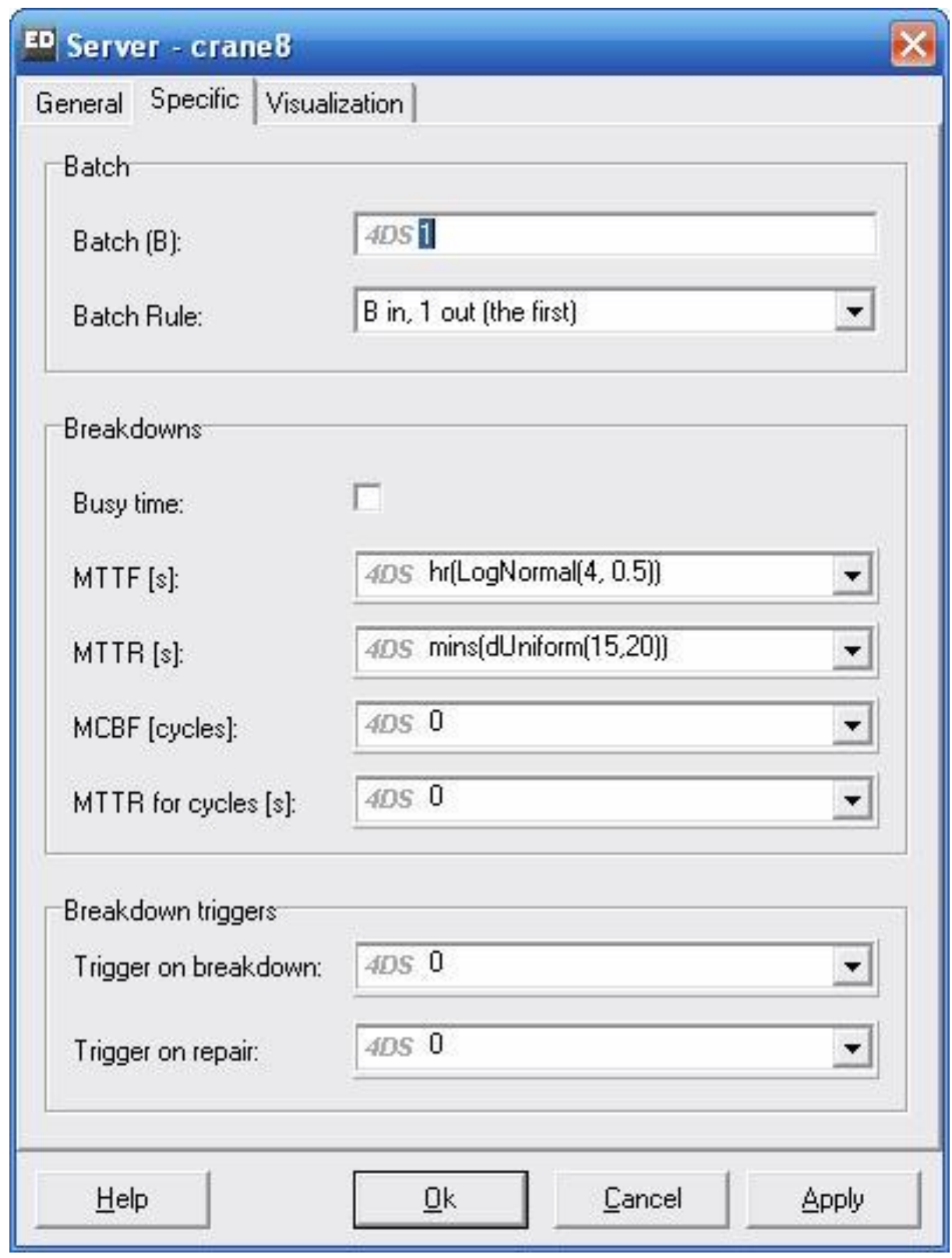

Figure 30 : Example for a atom specific : crane 8 breakdown : meantime to failure 4 hours (lognormal distribution with 0,5 hours) and meantime to repair with uniform distribution between 15 and 20 minutes 


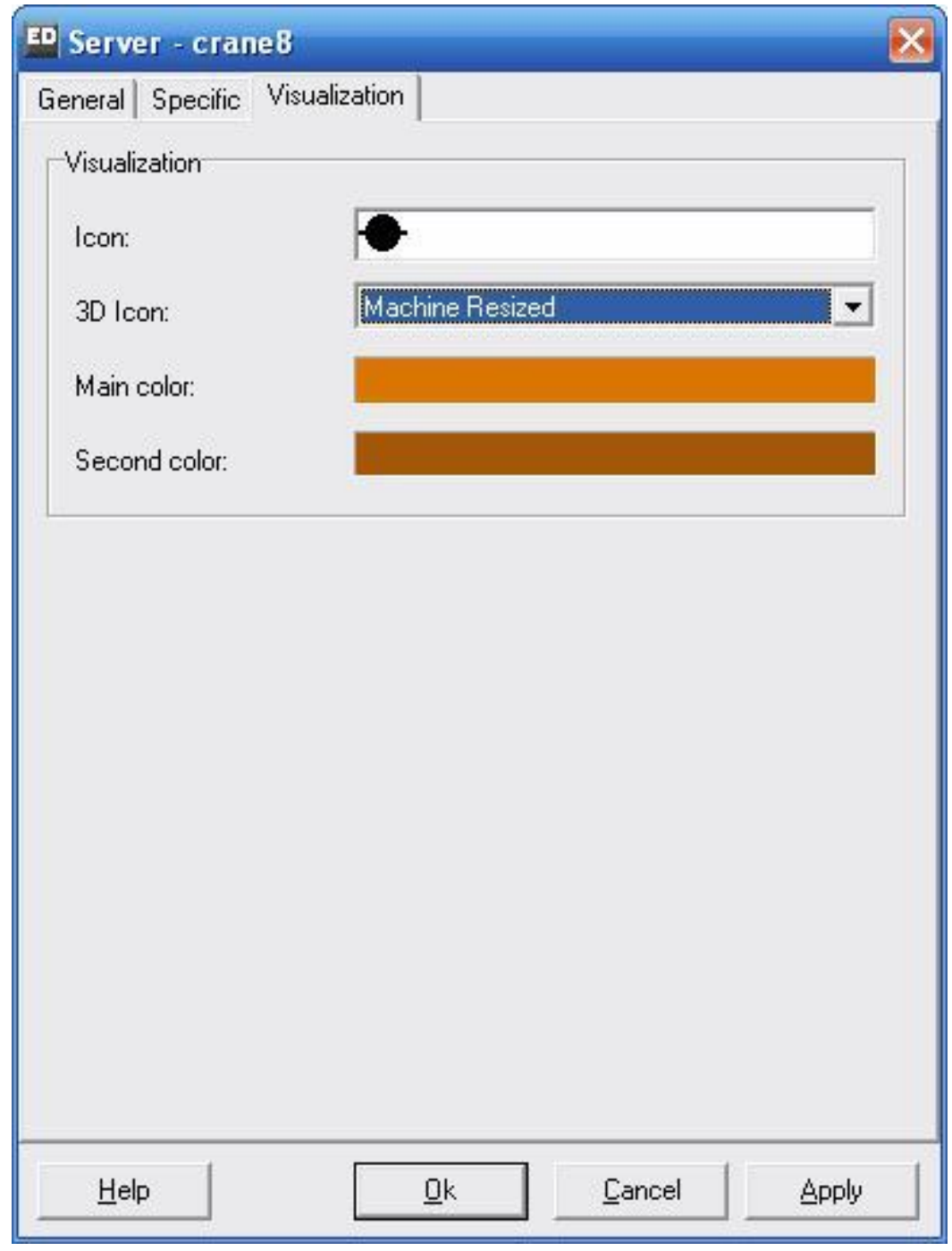

Figure 31 : Example of a atom vizualisation : main colour 


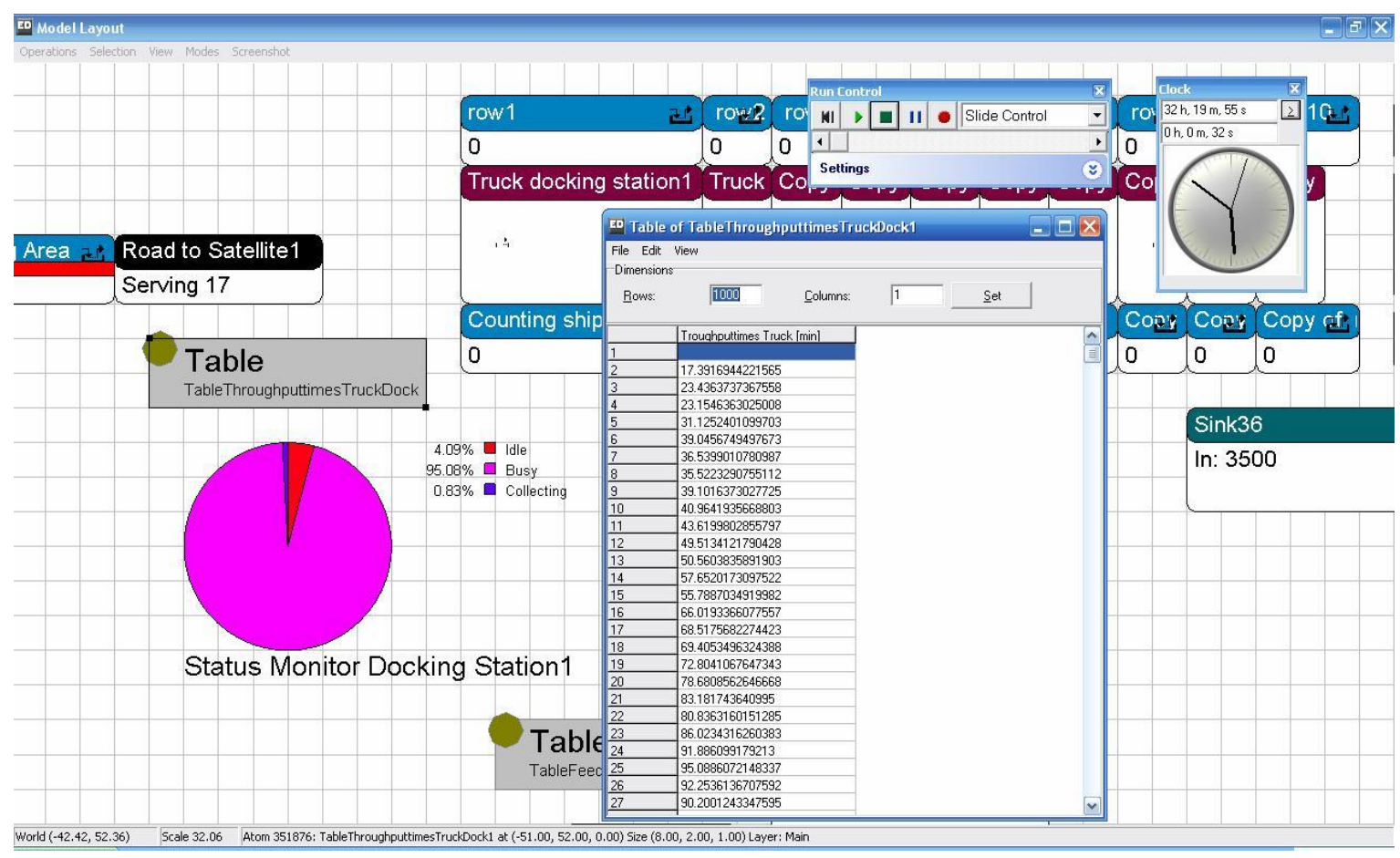

Figure 32 : Example for status monitor and throughput tables with throughput times

The status monitor can be linked at each element (atom), to survey how busy this element is and what percentage the element is idle. The above example is from a docking station which is busy with $95,08 \%$ and is only $4,09 \%$ of the time empty. The control of the results will happen during simulation with a status monitor ( see figure 32 ), which could be switched to each important process-atom to control load factor, efficieny and bottlenecks and overdimension. With the throughput table, the throughput time from beginning of the unloading/loading process to the position in the process where the table is locked in the total throughput time, can be listed and compared. 
Another instrument to follow the container, is the "tracer", with which the throughput ( time or numbers / volume ) can be followed during the simulation ( Figure 33 ) at specific positions.

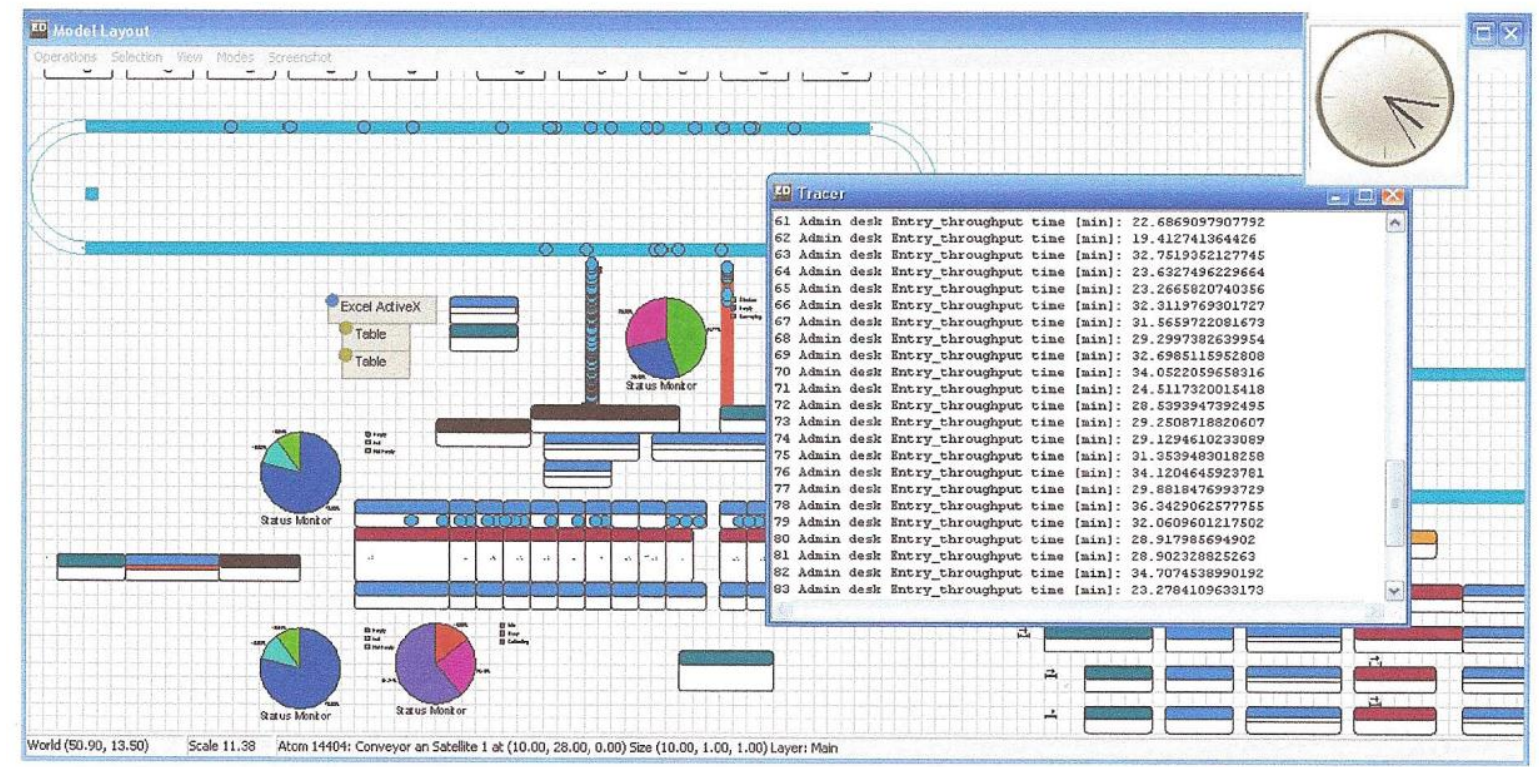

Figure 33 : Example for a tracer

With the tracer it is possible to control the time which is needed to service at specific critical service points. The above example shows the administration desk and the variation of time needed. 


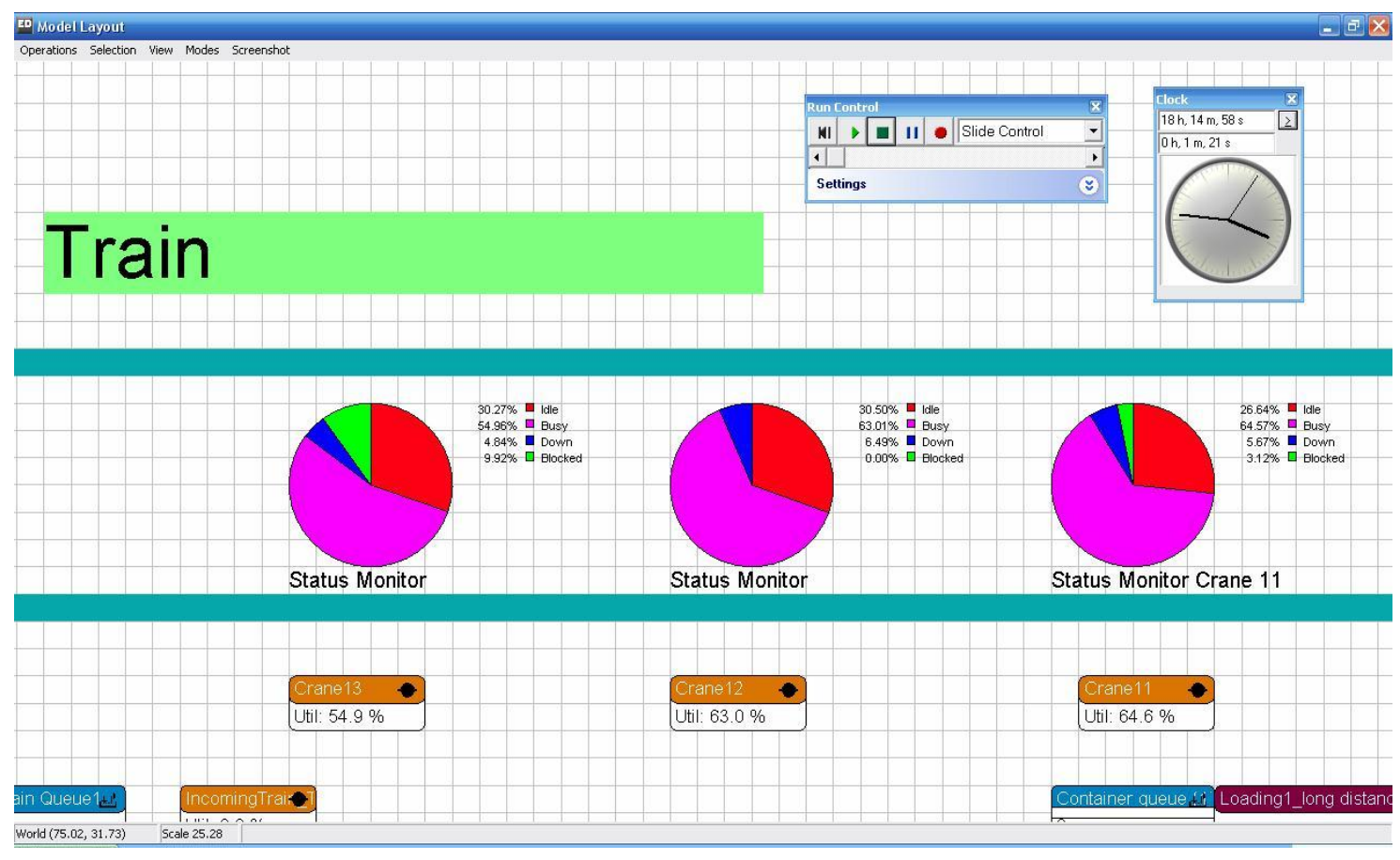

Figure 34 : status monitor of the three cranes loading the trains

It is helpful to control the load factor of parallel equipment. In the above case the three cranes at the train station. It is to evaluate down-times, idle times and blocked times. This allows to optimize processes and equipment. In the same Figure it is to see the utilization of each crane. In this case between 54,9 and 64,6\%. Another important information of the process is the table of departure times in the following example of the trains. 


\begin{tabular}{|c|c|c|c|c|c|c|}
\hline ED Tabl & of Table & ainTime & & & & $-\square \times$ \\
\hline File Edi & View & & & & & \\
\hline Dimensic & & & & & & \\
\hline Rows: & 12 & & olumns: & 5 & Set & \\
\hline & track1 & track2 & track3 & track4 & track5 & \\
\hline 1 & 4.41 & 3.23 & 1.44 & 1.55 & 1.81 & \\
\hline 2 & 9.19 & 7.28 & 2.84 & 2.84 & 4.84 & \\
\hline 3 & 13.86 & 12.91 & 4.33 & 4.38 & 6.34 & \\
\hline 4 & 17.99 & 17.91 & 5.7 & 5.84 & 8.84 & \\
\hline 5 & & & 7.13 & 7.23 & 11.4 & \\
\hline 6 & & & 8.73 & 9.44 & 13.24 & \\
\hline 7 & & & 10.13 & 10.18 & 15.46 & \\
\hline 8 & & & 11.75 & 11.76 & 18.13 & \\
\hline 9 & & & 13.51 & 13.53 & & \\
\hline 10 & & & 14.74 & 14.76 & & \\
\hline 11 & & & 16.31 & 16.3 & & \\
\hline 12 & & & 18.17 & 18.25 & & \\
\hline
\end{tabular}

Figure 35 : List of train departure times at each track.

At each time of the simulation and especially at the end of the simulation run, there can be a summary report for each atom or process element created, where the the container is passing ( Figure 36 ). 


\section{summary report}

\begin{tabular}{|c|c|c|c|c|c|}
\hline name & \multicolumn{2}{|c|}{$\begin{array}{l}\text { content } \\
\text { current average }\end{array}$} & \multicolumn{2}{|c|}{$\begin{array}{l}\text { throughput } \\
\text { input output }\end{array}$} & $\begin{array}{l}\text { staytime } \\
\text { average }\end{array}$ \\
\hline TableThroughput & 0 & 0.000 & 0 & 0 & 0.000 \\
\hline TableThroughput & 0 & 0.000 & 0 & 0 & 0.000 \\
\hline TableTrainTimes & 0 & 0.000 & 0 & 0 & 0.000 \\
\hline TableFeederLoad & 0 & 0.000 & 0 & 0 & 0.000 \\
\hline Container & 0 & 0.000 & 0 & 0 & 0.000 \\
\hline TableSat1Loadin & 0 & 0.000 & 0 & 0 & 0.000 \\
\hline TableSat2Loadin & 0 & 0.000 & 0 & 0 & 0.000 \\
\hline TableTrainLoadi & 0 & 0.000 & 0 & 0 & 0.000 \\
\hline ExcelActiveX92 & 2 & 2.000 & 0 & 0 & 0.000 \\
\hline Destination & 0 & 0.000 & 0 & 0 & 0.000 \\
\hline ship 1 & 0 & 0.000 & 5000 & 5000 & 0.000 \\
\hline target ship1 & 0 & 0.000 & 5000 & 5000 & 0.000 \\
\hline crane 1 & 0 & 0.611 & 2000 & 2000 & 35.557 \\
\hline crane2 & 0 & 0.622 & 2000 & 2000 & 36.222 \\
\hline crane3 & 0 & 0.623 & 2000 & 2000 & 36.285 \\
\hline crane4 & 0 & 0.622 & 2000 & 2000 & 36.199 \\
\hline crane5 & 0 & 0.622 & 2000 & 2000 & 36.171 \\
\hline Accumulating Co & 0 & 5.489 & 39916 & 39916 & 16.006 \\
\hline Accumulating Co & 0 & 5.487 & 39916 & 39916 & 16.000 \\
\hline Accumulating Co & 0 & 5.487 & 39916 & 39916 & 16.000 \\
\hline Accumulating Co & 0 & 5.487 & 39916 & 39916 & 16.000 \\
\hline Accumulating Co & 0 & 5.487 & 39916 & 39916 & 16.000 \\
\hline Right Curved Ac & 0 & 0.539 & 39916 & 39916 & 1.571 \\
\hline Right Curved Ac & 0 & 0.539 & 39916 & 39916 & 1.571 \\
\hline Conveyor train & 0 & 11.524 & 41916 & 41916 & 32.001 \\
\hline conveyor satell & 0 & 12.612 & 43416 & 43416 & 33.811 \\
\hline Conveyor Satell & 0 & 27.524 & 43416 & 43416 & 73.789 \\
\hline cfeeder conveyo & 0 & 34.405 & 40916 & 40916 & 97.874 \\
\hline branch_to buffe & 0 & 4.036 & 39916 & 39916 & 11.769 \\
\hline conv - & 0 & 3.988 & 39916 & 39916 & 11.630 \\
\hline Container_ship1 & 0 & 0.000 & 0 & 0 & 0.000 \\
\hline Feeder & 0 & 0.000 & 0 & 0 & 0.000 \\
\hline Conveyor an Sat & 0 & 273.484 & 3500 & 3500 & 9094.969 \\
\hline Conveyor an Sa & 0 & 33.411 & 3500 & 3500 & 1111.111 \\
\hline Conveyor an tra & 0 & 0.969 & 2000 & 2000 & 56.422 \\
\hline Queue29 & 0 & 43.497 & 3500 & 3500 & 1446.533 \\
\hline Truck docking s & 1 & 0.997 & 403 & 402 & 287.661 \\
\hline row1 & 0 & 2.780 & 201 & 201 & 1610.086 \\
\hline Truck source & 1 & 0.677 & 3755 & 3754 & 20.994 \\
\hline Truck Parking A & 220 & 217.098 & 3754 & 3534 & 6921.242 \\
\hline Product34 & 0 & 0.000 & 0 & 0 & 0.000 \\
\hline Sink36 & 0 & 0.000 & 3500 & 0 & 0.000 \\
\hline Truck docking s & 1 & 0.998 & 413 & 412 & 280.945 \\
\hline row2 & 0 & 2.784 & 206 & 206 & 1573.241 \\
\hline Copy of Loading & 1 & 0.996 & 403 & 402 & 288.108 \\
\hline row3 & 0 & 2.768 & 201 & 201 & 1602.847 \\
\hline Copy of Loading & 1 & 0.998 & 419 & 418 & 276.223 \\
\hline row4 & 0 & 2.749 & 209 & 209 & 1530.733 \\
\hline Copy of Loading & 1 & 0.996 & 415 & 414 & 280.050 \\
\hline row5 & 0 & 2.768 & 207 & 207 & 1556.685 \\
\hline Copy of Loading & 1 & 0.997 & 409 & 408 & 282.254 \\
\hline row6 & 0 & 2.766 & 204 & 204 & 1577.951 \\
\hline
\end{tabular}

Figure 36 : Example of a part of the summary report $\left(1^{\text {st }}\right.$ page $)$ 


$$
\begin{gathered}
\&+\$ 37(5 \square \square \\
02^{\prime}(/[\text {; 3( 5,0 ( } 17 \$ 7,21 \square
\end{gathered}
$$

There will be made several different simulations with various modifications in

- $\quad$ physical properties of the atoms ( speed, cycle times, length )

- Capacities

- Disturbances

- Different modal split

\subsection{BASIC MODEL}

\subsubsection{Input values}

- unloading/loading of 2 container ships, carrying 5000 containers each

- moving of 20000 containers ( 10000 unloading, 10000 loading )

- $\quad$ basic modal split : $10 \%$ feeder ( sink )

$20 \%$ train ( 40 trains, 50 container each )

$35 \%$ satellite 1 ( truck)

$35 \%$ satellite $2($ truck=sink $)$

- 5 QC per ship, together $10 \mathrm{QC}$ 
- Cycle time of each QC : 30-90 seconds ( uniform distribution ) < 2hours from start and 15-45 seconds (uniform distr.) > 2 hours from start (simultaneous unloading / loading), interruptions : meantime to failure (MTTF) 4 hours, 0,5 hour (lognormal distrib.) and repair time : meantime to repair (MTTR) : 15-20 minutes (uniform distrib.)

- Each ship has 5 compartements with 1000 containers each

- Each ship has a BoL for 5000 containers with a fixed destination related to the modal split

- The simultaneous loading/unloading process starts after two hours from thestart of unloading. The assumption is that then a part of the compartment is empty.

- The yard carrousel has a total length of $3500 \mathrm{~m}$ and a speed of $5 \mathrm{~m} / \mathrm{sec}$

- The transportation system (conveyor) to feeder has a length of $300 \mathrm{~m}$ (is not important,because ending in a sink ) and reverse

- The transportation system to the trainstation has a length of $500 \mathrm{~m}$ and a speed of $9 \mathrm{~m} / \mathrm{sec}$ and reverse

- The transportation system to satellite 1 has a length of $5000 \mathrm{~m}$ and a speed of 9 $\mathrm{m} / \mathrm{sec}$ and reverse

- The transportation system to satellite 2 has a length of $10000 \mathrm{~m}$ and a speed of $9 \mathrm{~m} / \mathrm{sec}$ and reverse

- The trainstation carrousel has a total length of $1200 \mathrm{~m}$ and a speed of $9 \mathrm{~m} / \mathrm{sec}$

- 3 TC: cycle timeof each TC: $15-45 \mathrm{sec}$ (uniform distribution) first five containers 
only unloading then simultaneous loading/unloading

- interruptions: meantime to failure (MTTF) 4 hours,0,5 hour (lognormal distrib.) repair time : meantime to repair (MTTR) : 15-20 minutes (uniform distrib.)

- five rail tracks

- Rail track 1 and rail track 2 are for long distance Hinterland >1000 kilometer and there are generated every four hours one train on each track

- Railtrack 3, 4 and 5 are for medium distance to Hinterland ( three different Dryports or DC ). There are generated every 90 minutes one train, included 15 minutes for arrival of the train and 15 minutes for departure of the train.

- Each train can carry 50 containers

- Administration desk in satellite 1 with 20 counters and a cycle time per container for service of 5-7 minutes ( uniform distribution )

- $10 \%$ of the containers with destination satellite 1 will have a special treatment (customs check) and will be in quarantine for 8 hours,ie. their loading to trucks will be delayed

- Of the $90 \%$ ready for truck loading will be devided in $80 \%$ for direct shipping and $20 \%$ with a shipping window between 8 am and 4 pm, which causes a $16 \mathrm{~h}$ buffering

- 17 truck docking stations with a buffer for 3 containers in front of each and a cycle time for loading of 9 minutes with $\operatorname{logNormal}$ distribution of 2 minutes

- Road from the truck parking area with a drive tim (5/2) $\log$ Normal distribution

- 220 parking places for trucks in the waiting area. Waiting time for trucks before loading is 2 hours.

- Each truck is loading one container, which is dedicated by the BoL ( truck number is identical to container number ). 
- BoL incoming containers: the destination and the modalsplit is defined by the numbers and could be the base for planning the overall process and timing

- BoL outgoing containers: the two ships are devided in 10 compartments with a volume of 1000 containers each. The assumption is that the modal split is valid as well for the outgoing containers

- The focus of the simulation is put on the train transportation and to the truck transportation in satellite 1 . Satellite 2 is built as a sink, because there can be the same results as in satellite 1 expected. The feeder as well is built as a sink, because an immediate loading without intermediate storing is not realistic.

Feeders normally are loading containers which come from various ships and are collected a different berths

- The satellite can be considered as a Dryport with all functions (customs clearing, quarantine, container repair, collecting empty containers) .In consequence the containers can be sent directly to the customers

- The containers transported by train are sent to destinations some 100 or 1000 kilometer distance to DP or DC (see chapter 2.2). The customs clearing and administration activities normally take place there before the containers are distributed to the customers.

\subsubsection{Values to be observed in the simulation}

- Total time to unload and load the ships

- Total time for service the trains

- Total time until the last truck is leaving

- Throughput times for containers transported by 
---train

---trucks

- Train departure times and loading time variation

- Staytimes at specific joints and service points

- Status monitoring of loadfactor, capacities at service points

\subsubsection{Modifications of the basic model}

4.1.3.1 Reduction of the length of the yard-carrousel from $3500 \mathrm{~m}$ to $1500 \mathrm{~m}$

4.1.3.2 Extension of the length of the yard carrousel from $3500 \mathrm{~m}$ to $21500 \mathrm{~m}$

4.1.3.3 Extension of the length of the yard-carrousel to $21500 \mathrm{~m}$ and double speed in all transportation systems (TS)

4.1.3.4 Basic model but general reduced speed on all transportation systems to 5 meters/second

4.1.3.5 Basic model with 30 administration desks and doubled truck-loading stations

4.1.3.6 Basic model with 30 administration desks and tripled truck loading stations

4.1.3.7 Basic model without quarantine and limitation of loading corridor 8 am-4 pm and 30 administration desks in satellite 1

4.1.3.8 Basic model without quarantine, without loading corridor 8 am-4 pm,30 administration desks, and double truck-loading stations

4.1.3.9 Basic model but additional disturbances at

- yard carrousel

- transportation system to trainstation 
- transportation system to satellite 1

4.1.3.10 Basic model without QC 5 (only 4 QC for ship 1

4.1.3.11 Basic model without QC 4 and QC 5 (only 3 cranes for ship 1)

4.1.3.12 Modalsplit 2 :

- feeder : $30 \%$

- train : $40 \%$

- $\quad$ satellite $1: 20 \%$

- $\quad$ satellite $2: 10 \%$

4.1.3.12.1 Basic model with modalsplit 2

4.1.3.12.2 Basic model with modalsplit 2 but with yard - carrousel length of 21500 meters

4.1.3.13 Modalsplit 3 :

- feeder : $20 \%$

- train : $45 \%$

- $\quad$ satellite $1: 35 \%$

- $\quad$ satellite 2 : - 0 -

Basic model with modalsplit 3

\subsubsection{Comments to the modalsplit}

The modalsplit of harbors is depending on several major factors:

- --- geographic location

- $\quad$--- structure of the harbor (gateway or hub)

- --- transportation possibilities and infrastructure to Hinterland 
- --- transshipment possibilities /markets

- --- future growth of the harbor

- --- influence of limitations and legal rules for pollution

In Singapore port $90 \%$ of the container volume is transhipment with feeders. The reason is the geographic location in the street of Malacca, where one third of the world shipping trade is passing through. It is clear that a model for improvements must consider transhipment processes. In Shanghai and other Chinese harbors, the transhipment part is also quite high, because of missing roads and rails to the Hinterland. The containers are transported on the river. The chosen modalsplit 1,2 and 3 shall be a base for future developments. Nearly at every harbor, there are today already tremendous traffic problems for the trucks. With the expected growth of the container transportation, there is a need to manage the growth by increasing train and feeder in the modal split and reduce the truck transport in percent. In addition the pollution reglementation will support this change to trains and inland vessels. This trend is worldwide to notice. The port of Hamburg will increase in the modalsplit the train part from $36 \%$ to $41 \%$, which is together with the growth a doubling of the trains. Antwerp will reduce the truck part of today from $56 \%$ to $43 \%$ and increase train and feeder portion. These trends are built in the simulations with the 3 different modalsplit. 
Table 7 : Overview about the chosen modalsplit

\begin{tabular}{|l|c|c|c|}
\hline & Basic model & Modalsplit 2 & Modalsplit 3 \\
\hline feeder & $10 \%$ & $30 \%$ & $20 \%$ \\
\hline train & $20 \%$ & $40 \%$ & $45 \%$ \\
\hline Satellite 1 truck & $35 \%$ & $20 \%$ & $35 \%$ \\
\hline Satellite 2 truck & $35 \%$ & $10 \%$ & $-0-\%$ \\
\hline
\end{tabular}

\subsection{EXPERIMENTAL RESULTS}

\subsubsection{Basic model}

The simulation run shows that the model is functional working and is able to represent existing processes. All containers are unloaded and loaded completely. The monitoring of the equipment during the simulation run shows a continuous operating of the cranes ( QC, truck loading stations ) during their relevant activities. The transportation systems to the satellite 1 and to the trainstation are fulfilling their task as a "rolling buffer store" and allow a feeding of TCs and the trucks without interruption. In consequence the expected loading time of the trains and the trucks can be reached. Of course the model contains some simplifications, like direct flow of the containers from 
satellites and feeder transportation system, or not specific consideration of different container sizes including empty containers. But this was not the basic focus of the model and can be a matter of future research. The major message is, that the relevant processes of the logistic chain can be connected and with an entire, integrated planning of logistic steps, a just-in-time supply without any intermediate warehousing can be reached and the real overall timing and handling can be reduced. With the basic model, five runs were made, to compare the relevant values. They are shown in table 8 . The values in the table are collected from the controlling elements, described in chapter 3.3.4. As today's real overall unloading and loading time, variations are measured in hours and days, the statistical variance of the simulations overall timing in the range of minutes have no relevance to the target of the model. So only five runs were performed. 
Table 8 : Results of the basic model

\begin{tabular}{|c|c|c|c|c|c|c|}
\hline Basic model & Run1 & Run2 & Run3 & Run4 & Run5 & Avg R1-R5 \\
\hline $\begin{array}{l}\text { Ship } 1 \\
\text { total time for unload/load (hrs) }\end{array}$ & 20,15 & 20,06 & 20,45 & 20,13 & 20,25 & 20,21 \\
\hline $\begin{array}{l}\text { Ship } 2 \\
\text { total time for unload/load (hrs) }\end{array}$ & $20,45 h$ & $20,48 \mathrm{~h}$ & 20,63 & 20,33 & 20,30 & 20,44 \\
\hline last train departure $\quad$ (hrs) & 18,25 & 17,96 & 18,15 & 17,88 & 17,97 & 18,04 \\
\hline last truck leaving & 32,1 & 32,06 & 32,28 & 32,03 & 31,5 & 31,99 \\
\hline 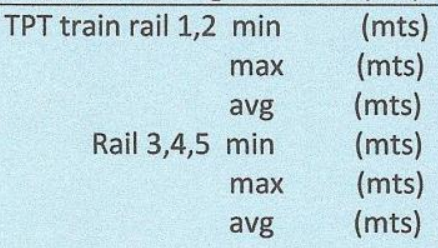 & $\begin{array}{l}4,2 \\
86,0 \\
19,6 \\
4,7 \\
532,8 \\
66,8\end{array}$ & $\begin{array}{l}4,2 \\
78,5 \\
16,4 \\
4,5 \\
264,45 \\
50,75\end{array}$ & $\begin{array}{l}4,4 \\
78,6 \\
16,9 \\
4,2 \\
243,8 \\
45,1\end{array}$ & $\begin{array}{l}4,3 \\
101,3 \\
18,2 \\
4,5 \\
295,5 \\
48,3\end{array}$ & $\begin{array}{l}4,4 \\
89,0 \\
15,3 \\
4,3 \\
275,7 \\
42,5\end{array}$ & $\begin{array}{l}4,3 \\
86,7 \\
17,3 \\
4,4 \\
322,8 \\
50,7\end{array}$ \\
\hline 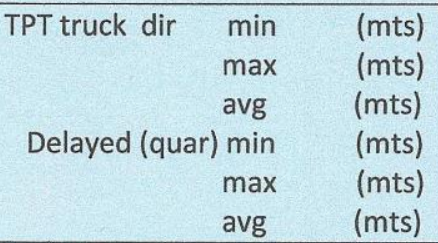 & $\begin{array}{l}17,4 \\
363,4 \\
197,6 \\
568,2 \\
1462 \\
889 \\
\end{array}$ & $\begin{array}{l}18,1 \\
376,5 \\
209,4 \\
561,7 \\
1427 \\
913 \\
\end{array}$ & $\begin{array}{l}19,6 \\
376 \\
216 \\
561,3 \\
1444 \\
933,9\end{array}$ & $\begin{array}{l}19,1 \\
380,7 \\
212 \\
565 \\
1477 \\
883\end{array}$ & $\begin{array}{l}18,05 \\
379,9 \\
211,5 \\
562 \\
1462 \\
906\end{array}$ & $\begin{array}{l}18,4 \\
375,3 \\
209,3 \\
563,4 \\
1454,4 \\
905\end{array}$ \\
\hline ST QC $1 . .10$ & $35,5-36,8$ & $35,3-36,9$ & $35,4-37,1$ & $35,3-36,3$ & $35,8-36,5$ & $35,3-37,1$ \\
\hline ST transp.syst. to sat. 1 & 9095 & 9313 & 9713 & 9225 & 9676 & 9404 \\
\hline avg content in sys. sat 1 (pcs) & 273 & 281 & 291 & 279 & 295 & 284 \\
\hline ST administration $\quad(\mathrm{sec})$ & 461,4 & 460,9 & 465,3 & 465,4 & 467,4 & 464,1 \\
\hline ST special treatment & 29781 & 29519 & 29805 & 29391 & 29883 & 29676 \\
\hline ST TC $11,12,13$ & $30,9-37,6$ & $31,8-33,4$ & $32,6-34,5$ & $30,8-32,5$ & $31,6-34$ & $30,8-37,6$ \\
\hline $\begin{array}{lll}\text { SM QC } 6 & \text { busy } & (\%) \\
& \text { down } & (\%) \\
& \text { utilization } & (\%)\end{array}$ & $\begin{array}{l}92,5 \\
5,8 \\
92,5 \\
\end{array}$ & $\begin{array}{l}92,6 \\
5,6 \\
92,7\end{array}$ & $\begin{array}{l}91,1 \\
7,3 \\
91,1\end{array}$ & $\begin{array}{l}92,7 \\
5,6 \\
92,8\end{array}$ & $\begin{array}{l}92,2 \\
5 \\
92,1\end{array}$ & $\begin{array}{l}92,2 \\
5,9 \\
92,2\end{array}$ \\
\hline $\begin{array}{r}\text { YCa "blind 2000m "blocked (\%) } \\
\text { empty (\%) }\end{array}$ & $\begin{array}{l}67,7 \\
3,4\end{array}$ & $\begin{array}{l}67,1 \\
3,9\end{array}$ & $\begin{array}{l}66,5 \\
3,7\end{array}$ & $\begin{array}{l}67,5 \\
3,5\end{array}$ & $\begin{array}{l}68,1 \\
3,8\end{array}$ & $\begin{array}{l}67,4 \\
3,7\end{array}$ \\
\hline $\begin{array}{lll}\text { SM TC } 11 & \text { busy } & (\%) \\
& \text { idle } & (\%) \\
& \text { down } & (\%)\end{array}$ & $\begin{array}{l}64,6 \\
26,6 \\
5,7\end{array}$ & $\begin{array}{l}66,8 \\
26,3 \\
6,8\end{array}$ & $\begin{array}{l}67,7 \\
24,1 \\
6,9\end{array}$ & $\begin{array}{l}66,4 \\
27,4 \\
5,2\end{array}$ & $\begin{array}{l}67,1 \\
22,7 \\
6,4\end{array}$ & $\begin{array}{l}66,5 \\
25,3 \\
6,2\end{array}$ \\
\hline $\begin{array}{ll}\text { SM TC } 12 & \text { busy } \\
\text { idle } \\
\text { down }\end{array}$ & $\begin{array}{l}63 \\
30,5 \\
6,5 \\
\end{array}$ & $\begin{array}{l}59,7 \\
33,2 \\
7\end{array}$ & $\begin{array}{l}59,5 \\
31,5 \\
4,8\end{array}$ & $\begin{array}{l}59,8 \\
33,8 \\
6,3\end{array}$ & $\begin{array}{l}61,2 \\
30,2 \\
6,8\end{array}$ & $\begin{array}{l}60,6 \\
31,8 \\
6,3 \\
\end{array}$ \\
\hline $\begin{array}{ll}\text { SM TC } 13 & \begin{array}{l}\text { busy } \\
\text { idle } \\
\text { down }\end{array} \\
\end{array}$ & $\begin{array}{l}54,9 \\
30,3 \\
4,8\end{array}$ & $\begin{array}{l}59,2 \\
34,7 \\
6,1\end{array}$ & $\begin{array}{l}56,5 \\
37 \\
6,4\end{array}$ & $\begin{array}{l}60 \\
34,1 \\
6,9\end{array}$ & $\begin{array}{l}57,5 \\
36,3 \\
6,2\end{array}$ & $\begin{array}{l}57,6 \\
34,5 \\
6,1\end{array}$ \\
\hline $\begin{array}{r}\text { SM trans.Sy.to Sat1 busy (\%) } \\
\text { blocked (\%) }\end{array}$ & $\begin{array}{l}33,7 \\
66,3\end{array}$ & $\begin{array}{l}30,9 \\
69,1\end{array}$ & $\begin{array}{l}31,2 \\
68,8\end{array}$ & $\begin{array}{l}31,8 \\
68,2\end{array}$ & $\begin{array}{l}30,4 \\
69,6\end{array}$ & $\begin{array}{l}31,6 \\
68,4\end{array}$ \\
\hline $\begin{array}{lll}\text { SM admin.desks } & \begin{array}{l}\text { busy } \\
\text { idle }\end{array} \\
& (\%)\end{array}$ & $\begin{array}{l}69,5 \\
30,5\end{array}$ & $\begin{array}{l}70,3 \\
29,7\end{array}$ & $\begin{array}{l}70,2 \\
29,8\end{array}$ & $\begin{array}{l}71,1 \\
28,9\end{array}$ & $\begin{array}{l}72 \\
28\end{array}$ & $\begin{array}{l}70,6 \\
29,4\end{array}$ \\
\hline $\begin{array}{ll}\text { SM truck docking } & \text { busy }(\%) \\
& \text { idle }(\%)\end{array}$ & $\begin{array}{l}95,9 \\
4,1\end{array}$ & $\begin{array}{l}96,6 \\
3,4\end{array}$ & $\begin{array}{l}96,4 \\
3,6\end{array}$ & $\begin{array}{l}97,4 \\
2,6\end{array}$ & $\begin{array}{l}98,2 \\
1,8\end{array}$ & $\begin{array}{l}96,8 \\
3,1\end{array}$ \\
\hline $\begin{array}{r}\text { busy (\%) } \\
\text { empty (\%) } \\
\text { blocked (\%) }\end{array}$ & na & $\begin{array}{l}79,7 \\
10,7 \\
9,6 \\
\end{array}$ & $\begin{array}{l}75,7 \\
20,9 \\
3,4 \\
\end{array}$ & $\begin{array}{l}73,7 \\
11,9 \\
14,4\end{array}$ & $\begin{array}{l}74,3 \\
18,2 \\
7,5 \\
\end{array}$ & $\begin{array}{l}75,8 \\
15,4 \\
8,7 \\
\end{array}$ \\
\hline
\end{tabular}

Comment :differences to $100 \%$ have different causes 
The major value for productivity is, how fast the ships, trains and trucks are loaded and unloaded. Discussion of the founded results :

Ships :

The ships are ready to leave with an average time of 20,21 hours ( ship 1 ) and 20,44 hours ( ship 2 ). The time range for the 4 runs is quite narrow within 24 minutes for ship 1 and 19 minutes for ship 2.

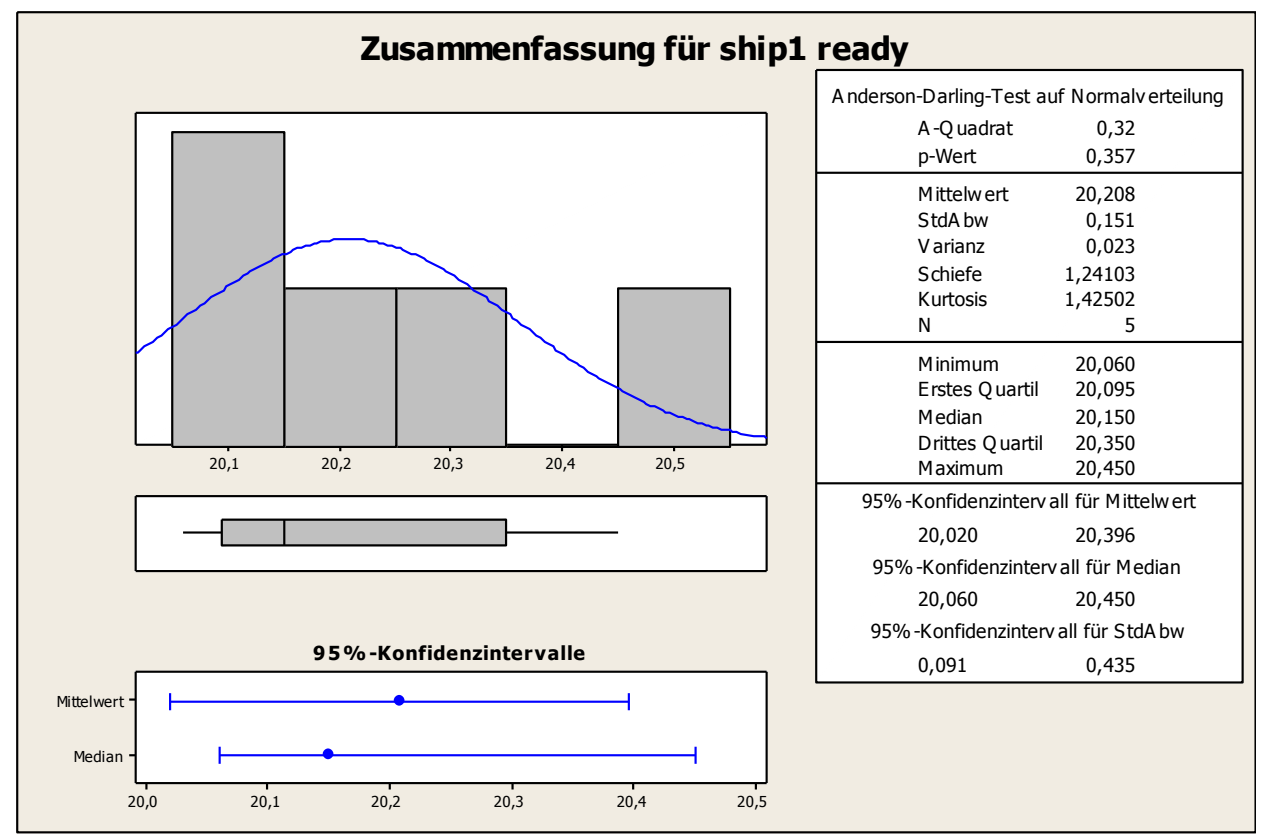

Figure 37 : Distribution for departure of ship 1

The simulation shows that the cycle time of the QC have a major impact to the ships unloading and loading time. The QC have a very constant utilization of about $92 \%$ with statistical defined downtimes. They do not show any idle time. The average staytime of 
the containers at the QC is between 35 and 37 seconds, which is quite short, due to the simultaneous unloading/loading process. This means 100 containers an hour for each crane (50 unloaded und 50 loaded), except at the first and last two hours.

Trains:

The last train departure is in average after 18,04 hours with a range of 22 minutes. The departure of the single trains is not this homogenious. In Figure 35 are the time differences of the departure of the follow up trains.

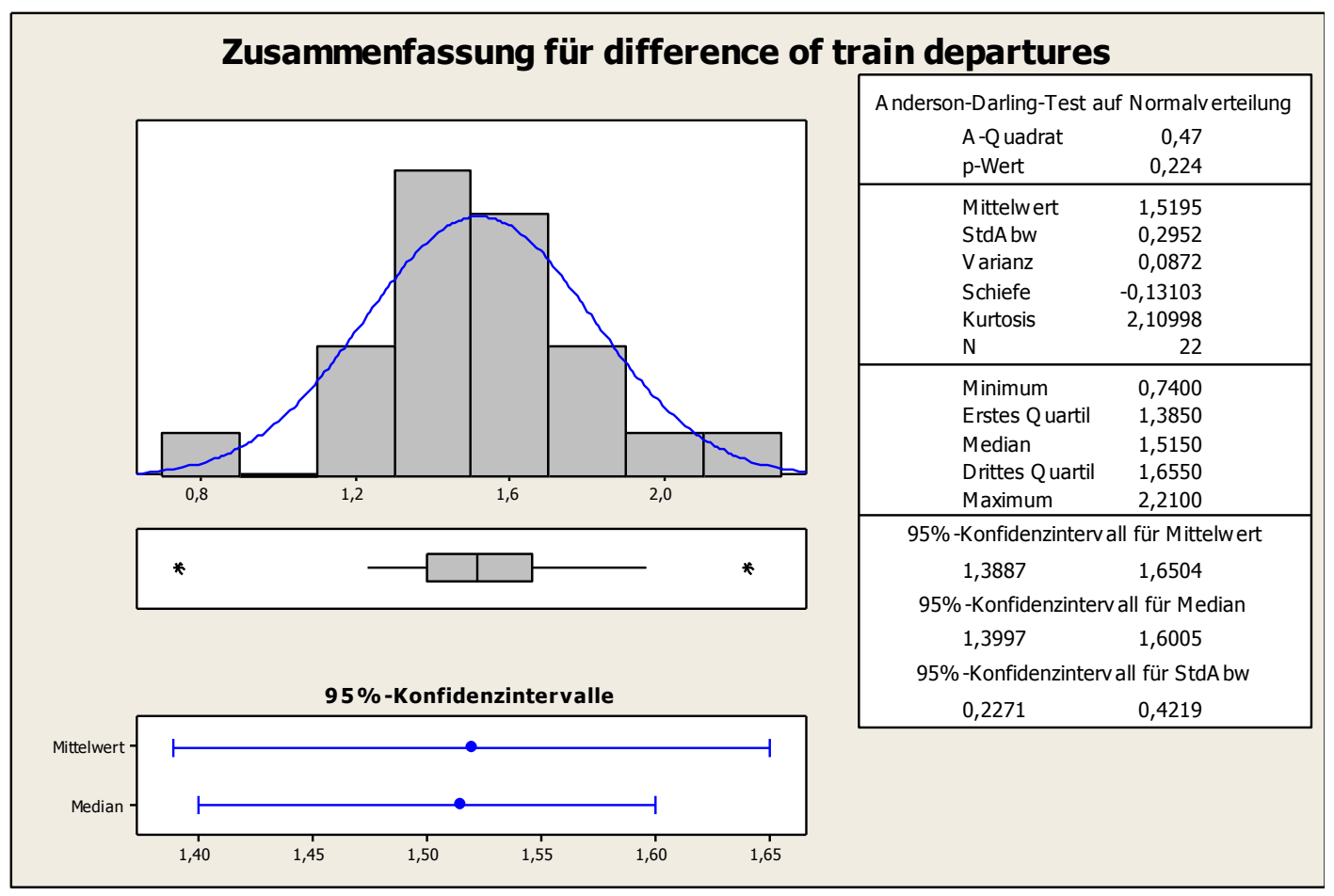

Figure 38 : difference of train departures during one run 
Considering the average staytime of the containers at the TC, which is between 30,8 and 37,7 seconds, this does not give any explanation, that we have a spread between 0,74 hours and 2,21 hours of the departures. The average value is at 1,52 hours, which is slightly higher than the given input value of 1,5 hours. If we are looking to the status monitor of the TC, there is a possible explanation. The TC are in average $25,4 \%$ and $34,5 \%$ idle. Figure 36 shows an example.

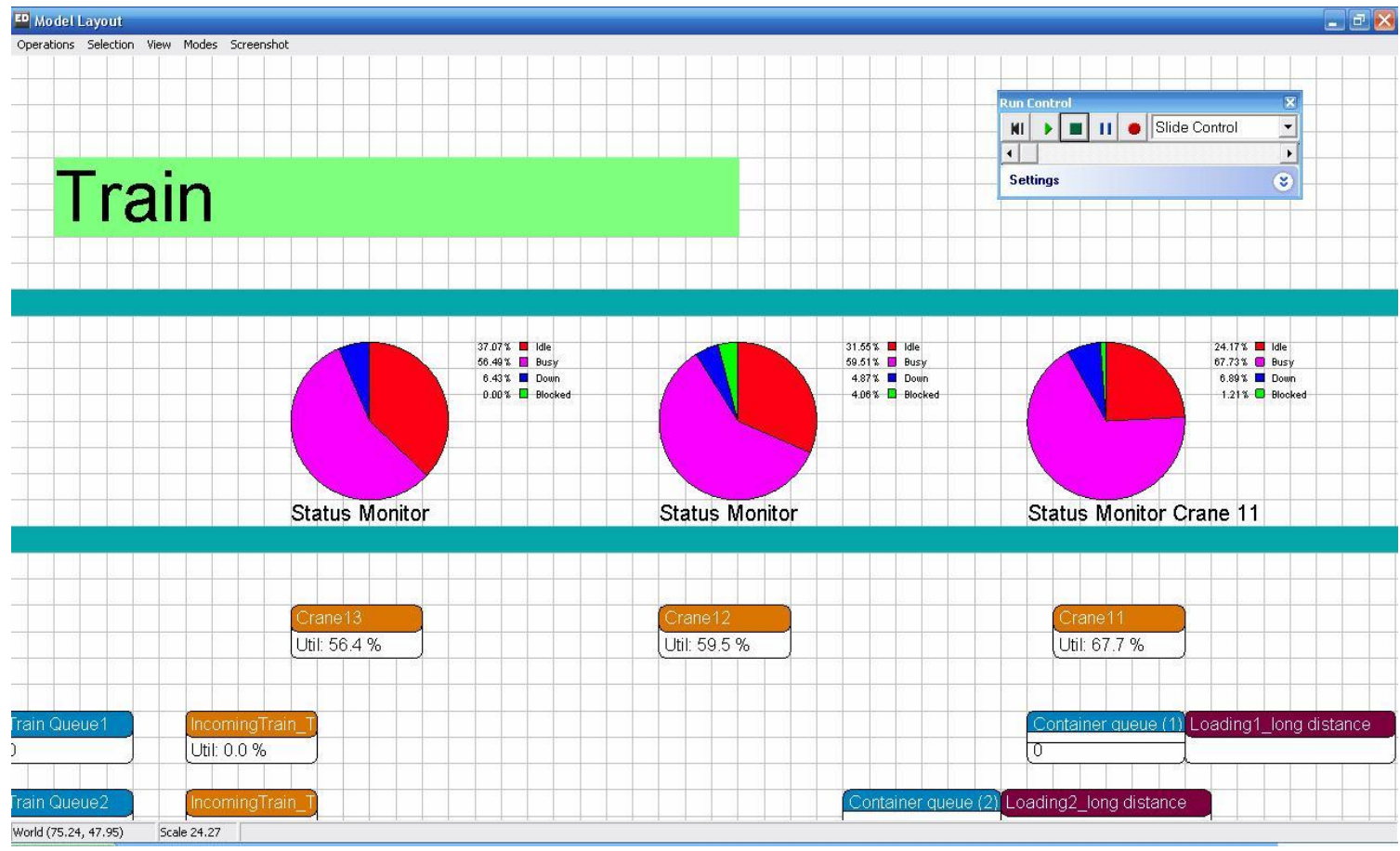

Figure 39 : Status monitor for the TC in the basic model

The reason, that the TC are idle, can be seen with the status monitor in Figure 40. There is shown that the train-carrousel (TCa) is either $21 \%$ empty or 3,3\% blocked, so the TC have to wait, until a container arrives. With a first quick view it seems, if the idle times of 
the TC are added, that there are only two TC necessary. The simulation run shows, that then the model is not running, because the TCa is complete blocked. A major reason for empty TCs is ,that each train needs $15 \mathrm{~min}$ to come into the trainstation and $15 \mathrm{~min}$ to leave. During these $30 \mathrm{~min}$ the TCs cannot serve this certain rail. So the compromise is to work with three cranes and to accept a utilization between 58 and $67 \%$. The difference between the TC is explained that TC 11 is first served by the TCa.

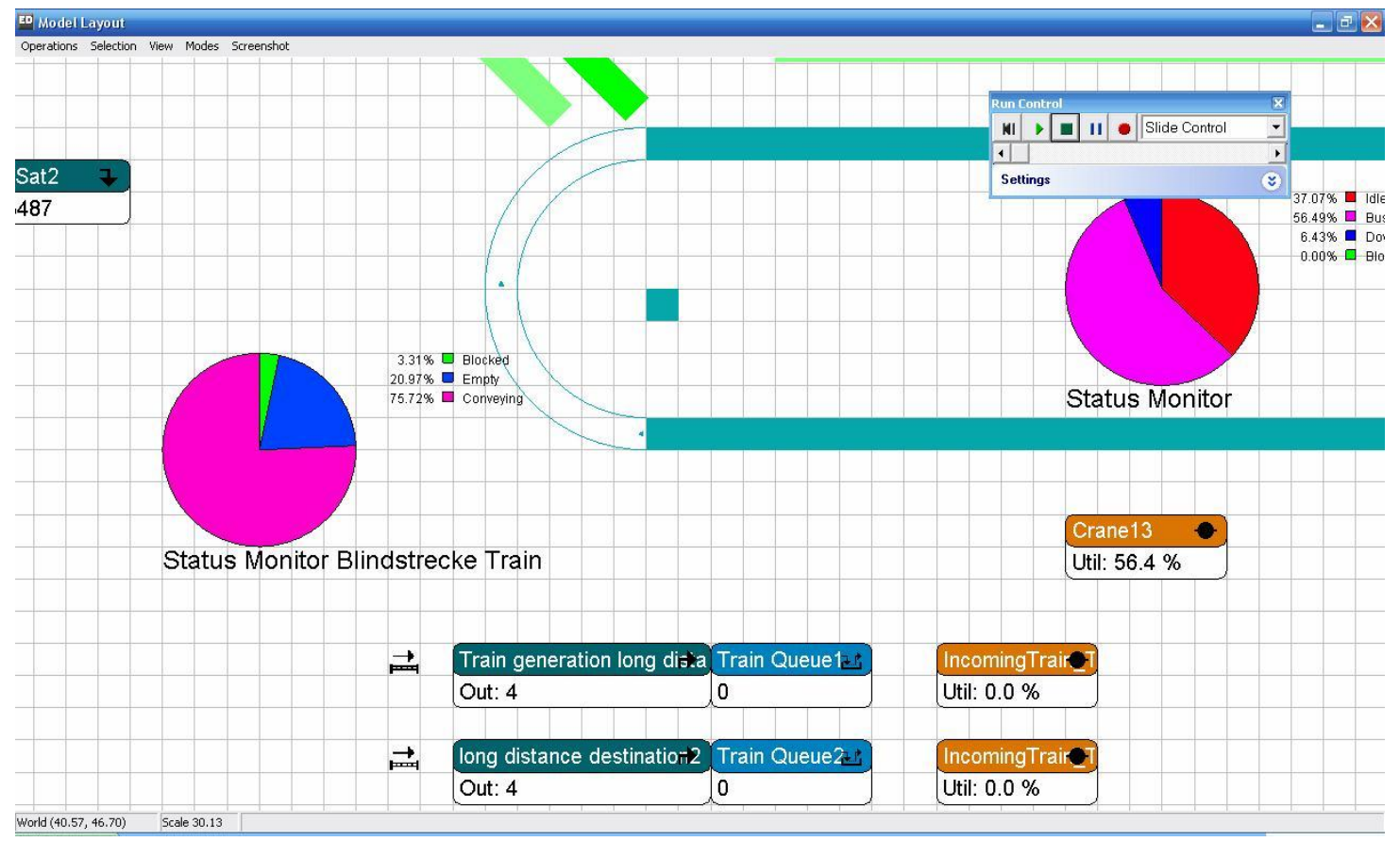

Figure 40 : Status monitor for the train caroussel

The train departure times are monitored during the simulation process and are written in a table. Example is shown in Figure 32. Another interesting information is the throughput times (TPT) for the containers from leaving the ship and loaded on the train. The TPT for each container is listed on a table and can be analyzed. It is deferred between the tracks 1 
and 2 (long distance) and the tracks 3, 4, 5 ( Dryports,DCs ). An example for the distribution of one run is shown in Figure 41 for long distance and in Figure 42 for DP/DC. In general, the first container has a very short TPT of about 4 minutes, as they run direct without any blocking. Then traffic on the transportation systems come up and slow down the TPT. During the simulation process it is to recognize, that there are accumulations on the transportation systems, esp. on the $\mathrm{YC}$ and the $\mathrm{TCa}$. For the rail tracks 1 and 2 there is an average TPT of 17,3 minutes. For the rail tracks 3, 4, 5 the average TPT is 50,7 minutes, but at maximum 322,8 minutes.

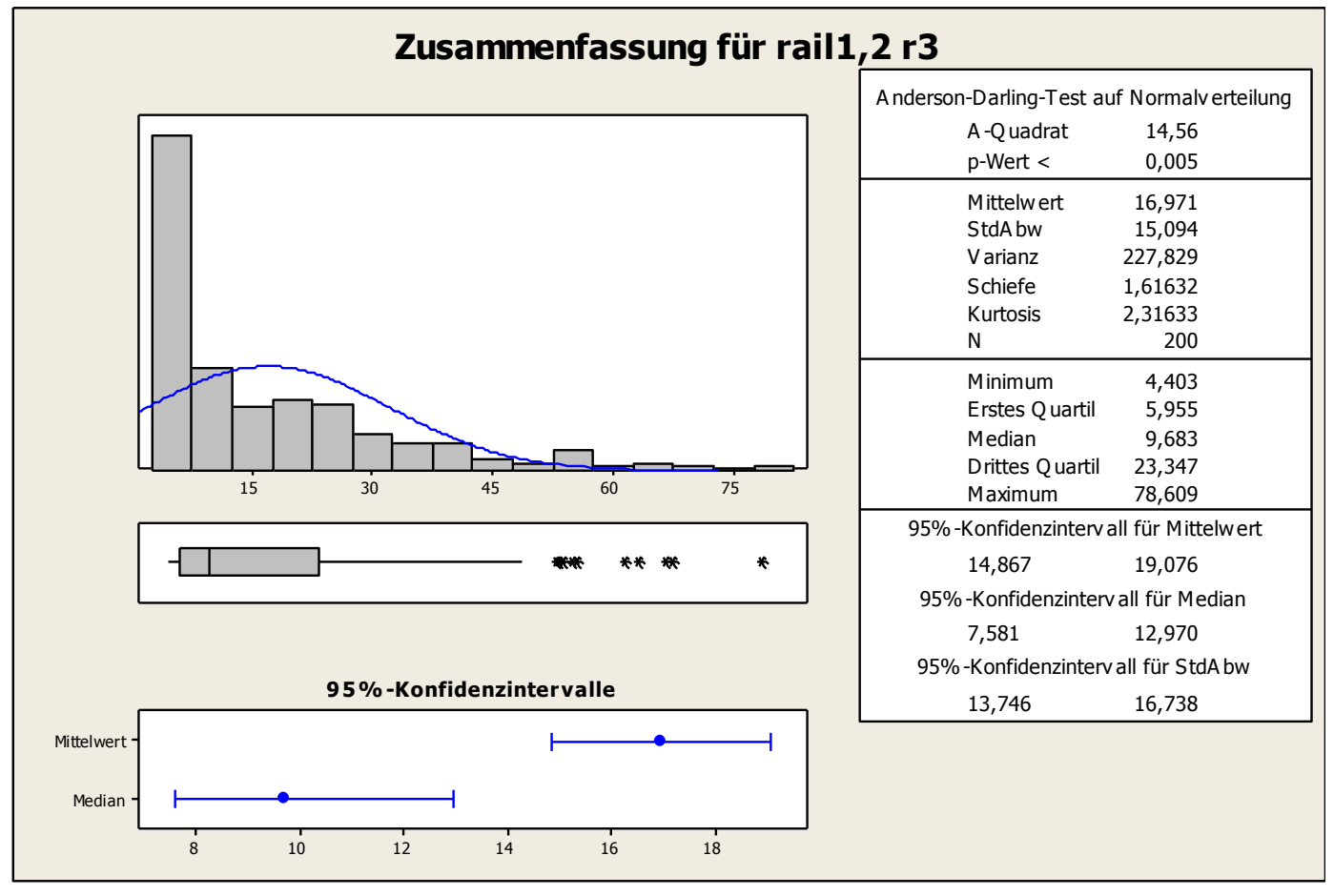

Figure 41 : Example for distribution of TPT railtrack 1 and 2 (long distance) 


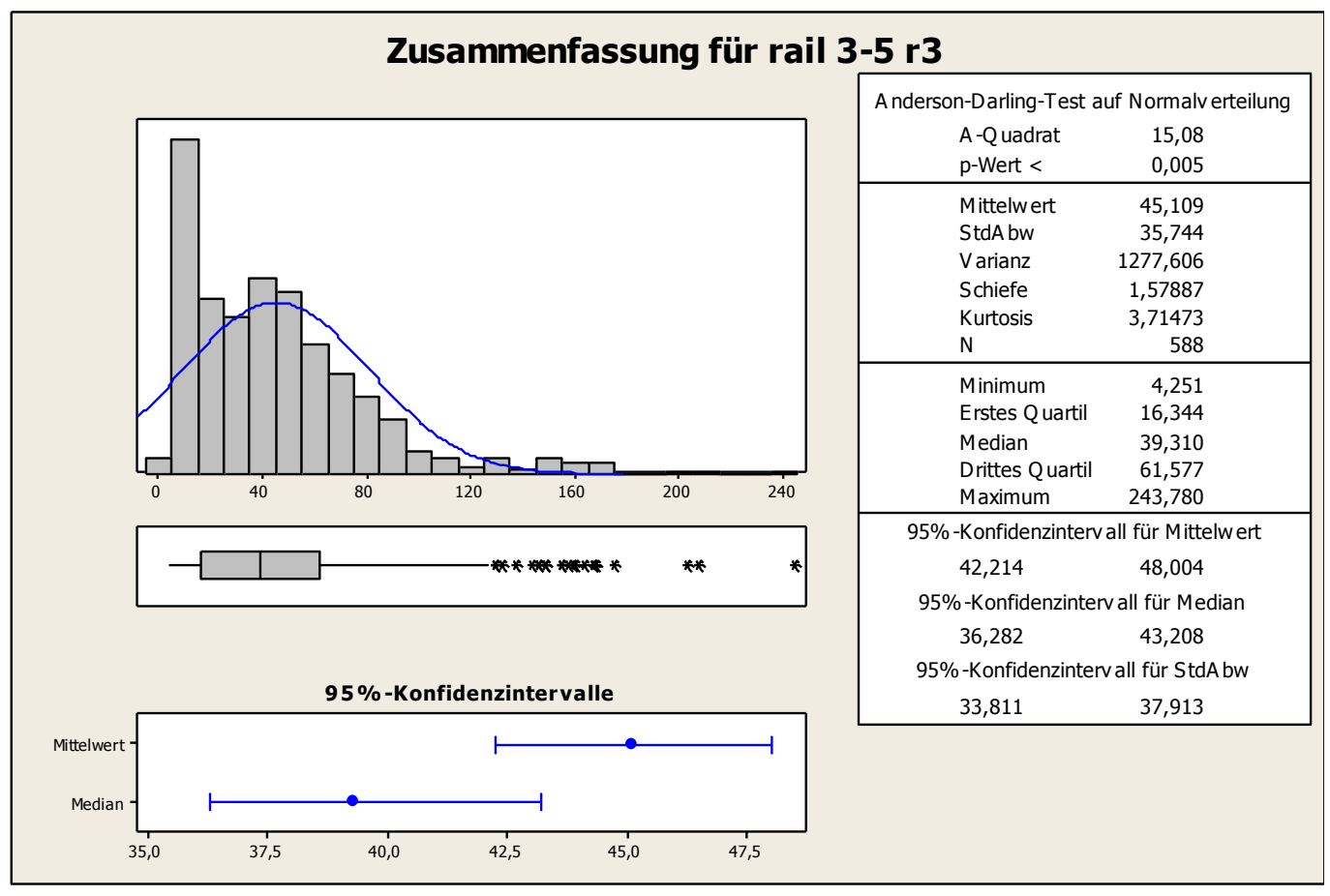

Figure 42 : Example for distribution of TPT railtrack 3,,4,5

Truck :

The last truck is leaving in average of the five run after 31,99 hours. This seems far late after the other processes ( ships, trains ) are already finished, but it is reasonable. With input values there were $10 \%$ of the containers put in satellite 1 for 8 hours in quarantine, so they are 8 hours on hold before further processing. $20 \%$ of the other containers have to be separated as they can be shipped only in a time corridor between 8 am and $4 \mathrm{pm}$. If they arrive at the terminal after $4 \mathrm{pm}$ they have to be collected and processed the next day after $8 \mathrm{am}$. This causes the longer TPT. Another observation is, that an average staytime of a container in the transportation system to satellite 1 (5000 m distance ) should be with a speed of $9 \mathrm{~m} / \mathrm{sec}$, not longer than 9,3 minutes. The average staytime is in the 5 runs 156,7 minutes. There is in consequence a accumulation in the transportation system. It is 
a "rolling stock". The average content in the system satellite 1 is 284 containers. A view to the theoretical capacities show the following :

- transportation system with speed of 9 meter/second produces at the end every 1,66 sec. 1 container

- administration with 20 desks, one container has an average ST of 464,1 sec. With 20 desks administration are produced every $23 \mathrm{sec} 1$ container - truck loading docking station with 17 docks can load every 31 sec 1 container

It is obvious that the capacities are not harmonized. The question is "Should they?" In reality there is not a must, because the transportation system can be a stock to get a continuous load factor to administration and truck service. There can easily a balance be found if necessary, by modification of the model. This is then a question of economic benefit, because increasing capacities in administration and truck service is not for free. This is as well a strategic question, if the future modalsplit will be changed and transfered from trucks to train and overcapacities may caused. Further in reality the truck loading area must cover the infrastructure for the containers to be loaded, which is not part of the model. 


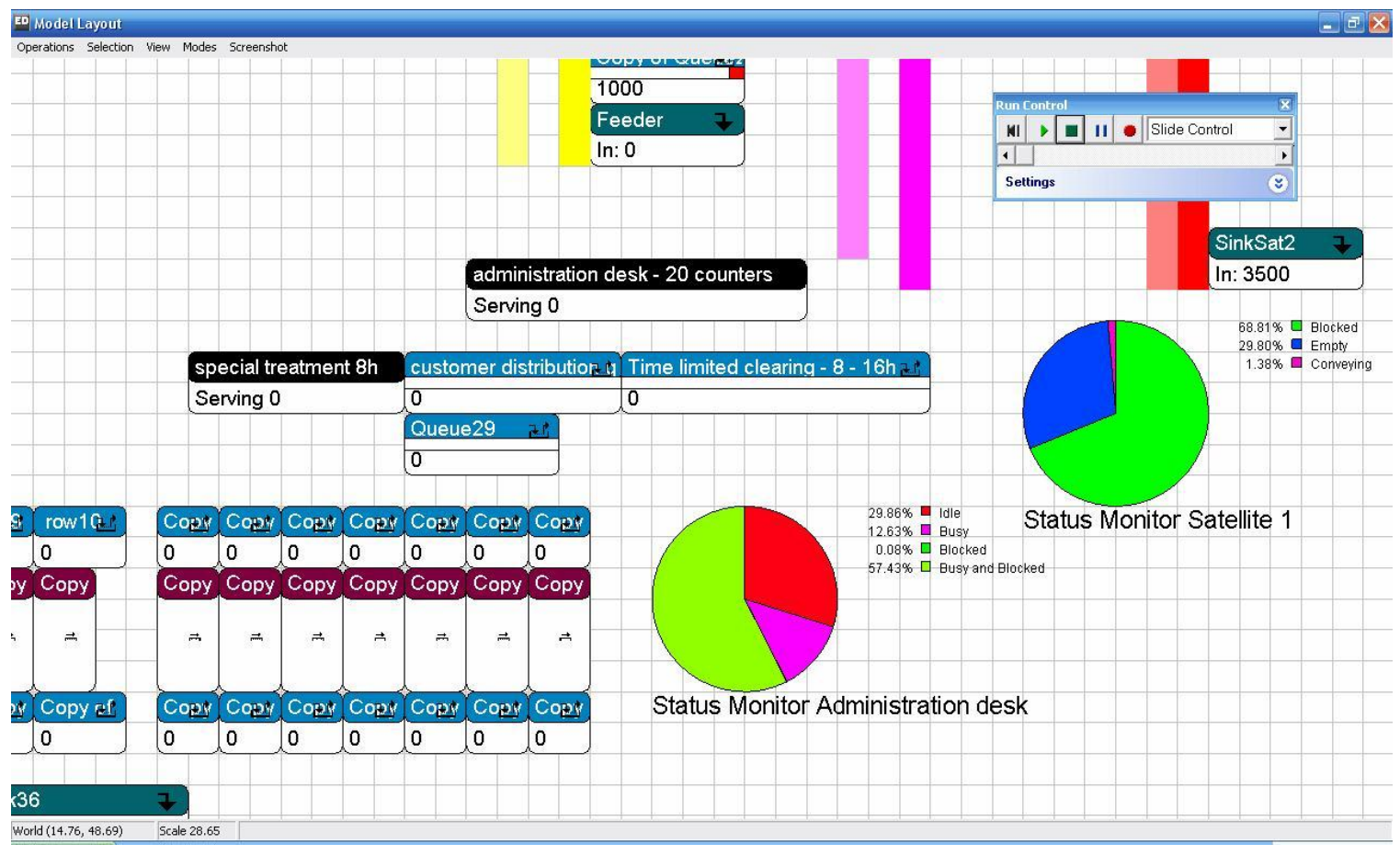

Figure 43 : Example for SM administration and SM satellite 1.The blockage in satellite is obvious and the idle time at administration is caused by the slow truck service 


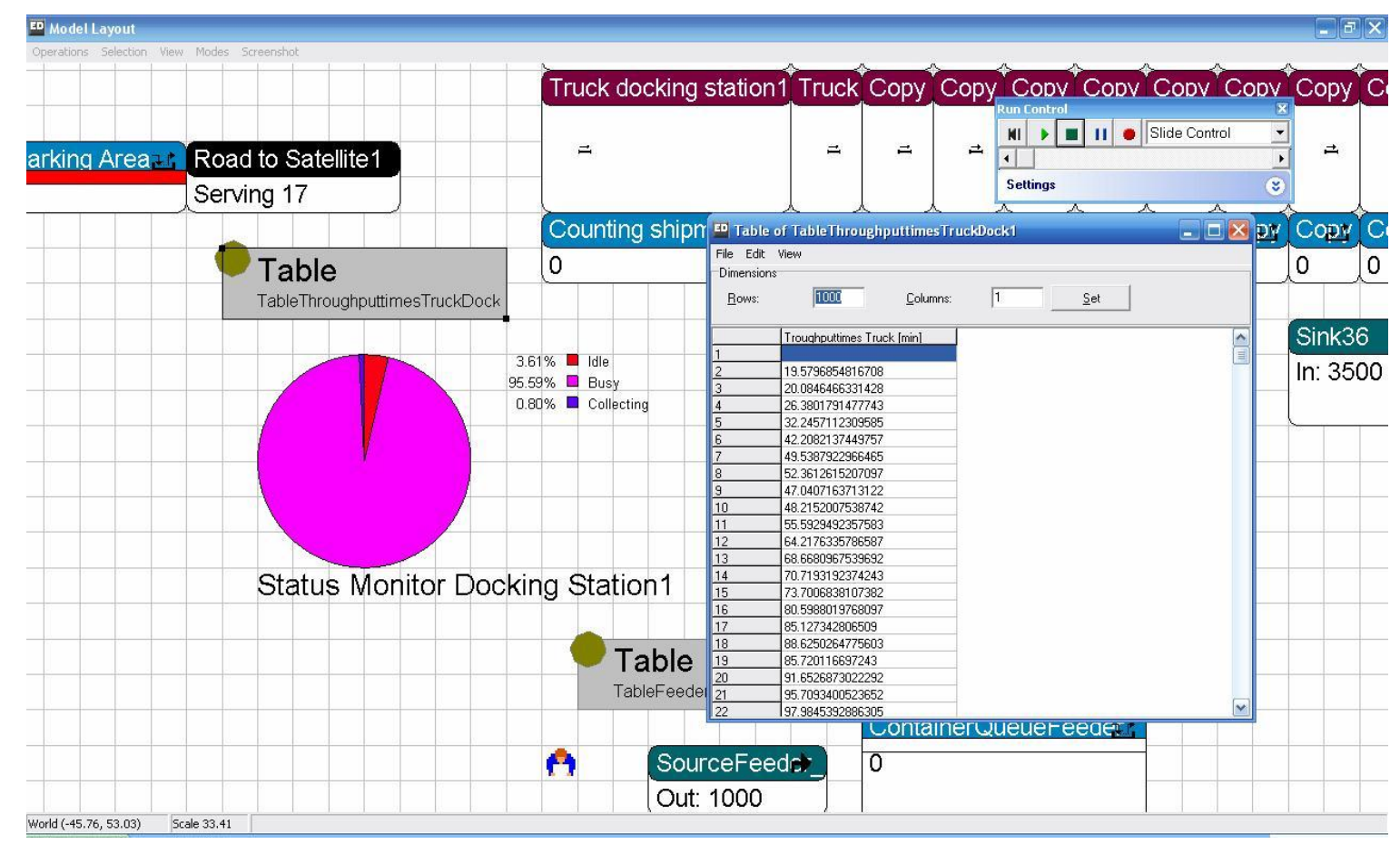

Figure 44 : The SM docking station truck

The TPT for the containers to the truck loading dock has to be considered twice. First there are the containers which run direct through. Second there are the containers which have to go into quarantine or have a shipment window 8 am-4 pm. So the TPT were selected in the table which is written during the simulation process. The results for the direct flow show at the beginning of the simulation a TPT of 18,4 min. The longest TPT was in average 375,3 minutes. The overall average (5 runs) 209,3 min. The indirect flow shows a minimum of 563,4 $\mathrm{min}$,the longest TPT $1454,8 \mathrm{~min}$. The average value for 5 runs is $905 \mathrm{~min}$. The distributions are illustrated in Figure 45 for the direct flow and in figure 46 for the indirect flow. It is obvious, that the docking station has a high efficiency and only $3 \%$ idle time. 


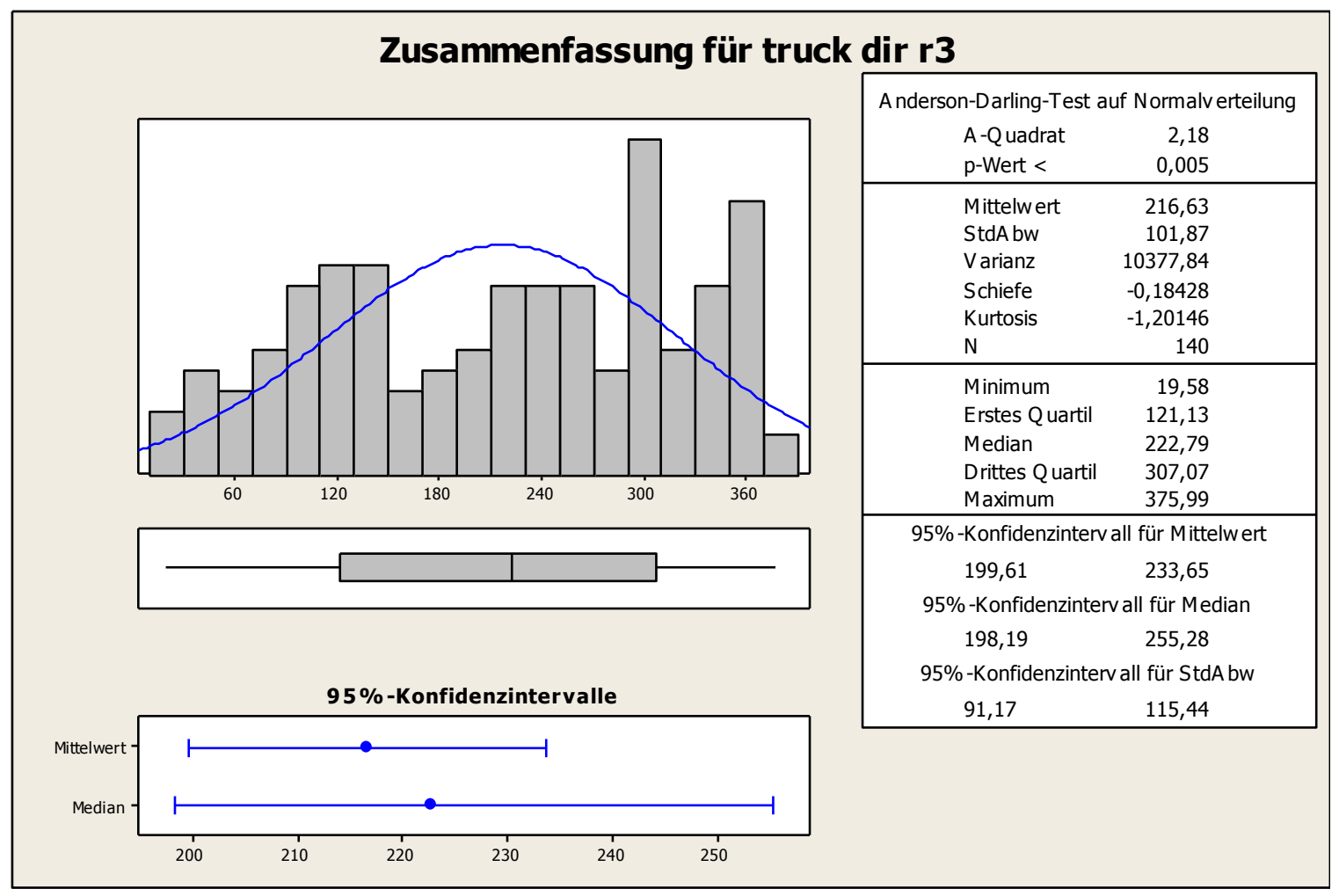

Figure 45 : Example for distribution TPT truck loading direct 


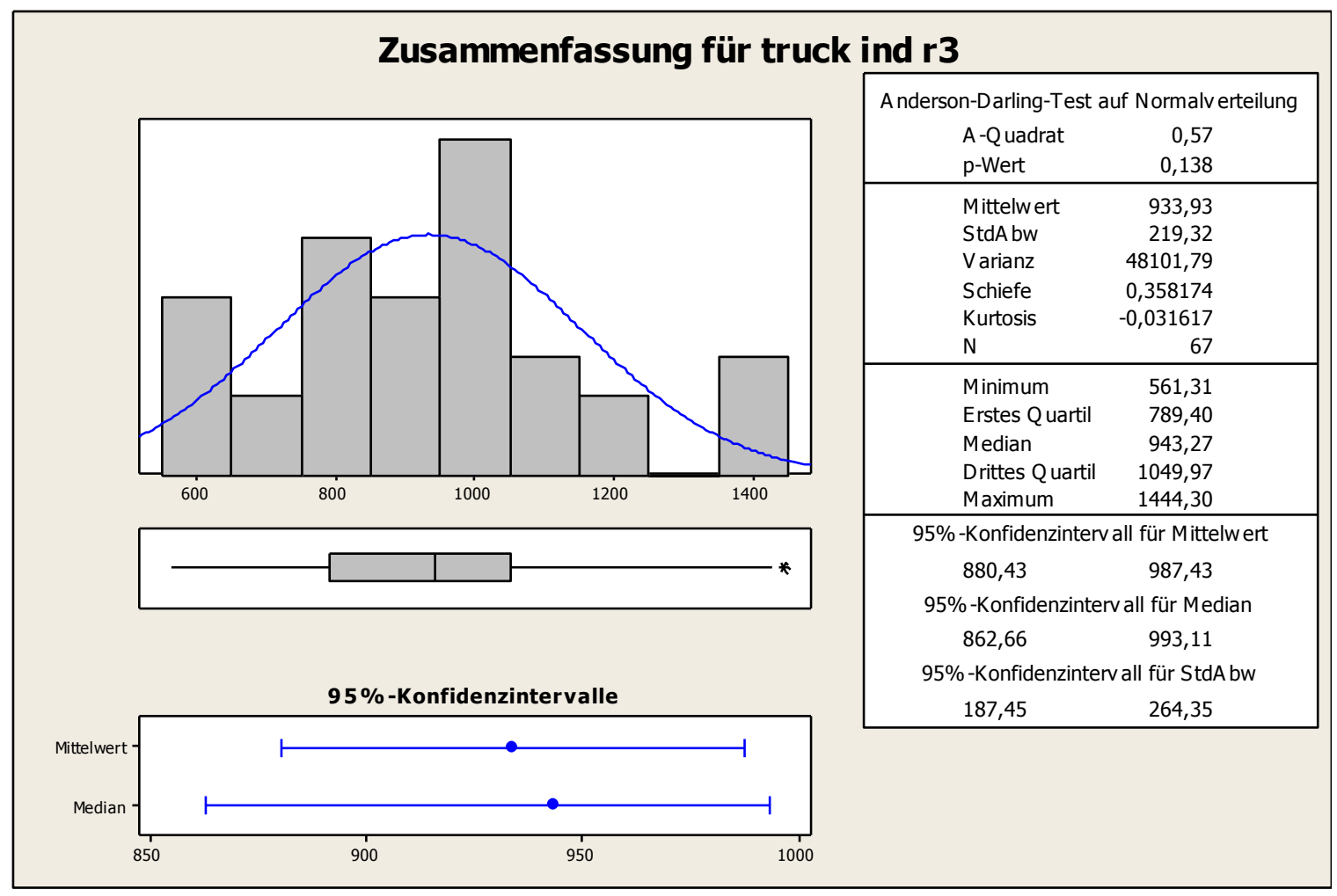

Figure 46 : Example for distribution TPT indirect truck loading

Yard carrousel ( YC ) :

The YC was designed in the model with a total length of $3500 \mathrm{~m}$, in consideration of the physical length of containers and the parallel unloading/loading process. It was obvious, that there will be flow problems. This is to observe with the SM YCa in Figure 43. 66,6 $\%$ of the simulation time the carrousel is blocked and is used as a "rolling store". In the summary report it can be seen, that each container is in average circuing two times until it reaches the foreseen destination. The interpretation is that the containers to be loaded are flowing to fast to the yard and can not be loaded immediately during a certain time period. This happens in a time frame between 5 hours and 12 hours after start of the simulation. A possible solution can be buffering before entry to the YCa to get more 
continuous flow. Nethertheless, there would not be any influence to the total process times for departure of the ships, trains and trucks.

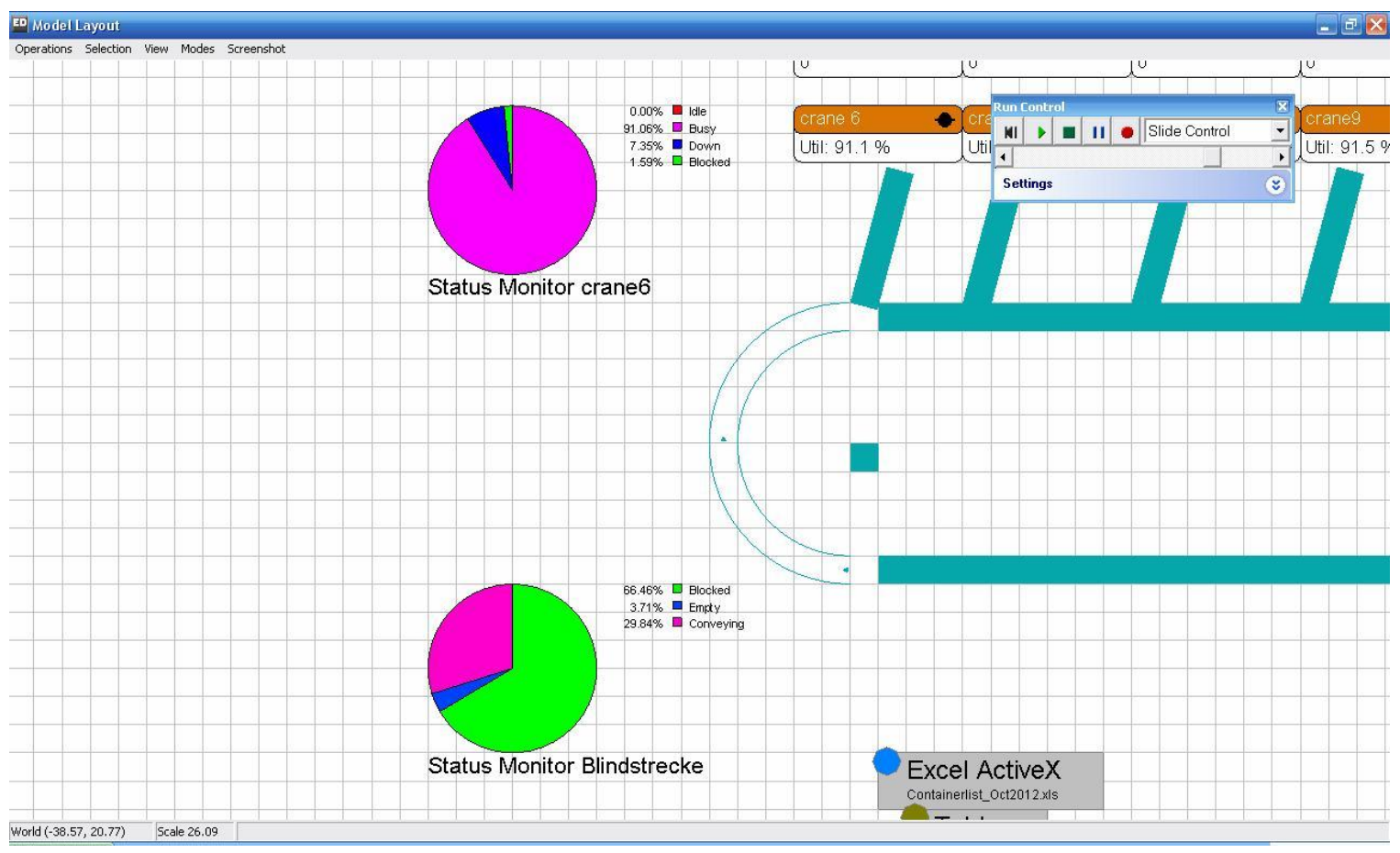

Figure 47 : SM for the YCa ( Blindstrecke ) 


\subsubsection{Comments to the basic model}

It has been shown that the simulation of such a complex architecture of logistic processes works and allows evaluations at each critical station. The results are reasonable and can open a way for higher efficiency and productivity of harbors, especially with the expected future growth of the container logistics. Important is, that only one process owner along the whole chain can manage all the interfaces and that all players show discipline. The bottlenecks of the overall processes are at the beginning and at the end of the process chain. The total time for unloading and loading the ships is limited with the capacity of the QC. To accelerate the transfer time of a ship means, either to add more cranes, or to grip two or three containers with one stroke, or to reduce the cycle time of a crane with two crabs (one for picking from the ship and one for loading onto the carrousel). The administration process time can be reduced with preparations in advance, so this should not be a limiting factor. The major challenge will be the truck loading. At first it is to manage the availability of the trucks at the right time. Traffic jams, accidents and breakdown of the truck can cause delays. This is not yet considered. The physical loading of containers to trucks is more sophisticated than the positioning i.e. on the carrousel. The easiest possibility to reduce the cycletime, will be, to add more docking stations and to increase the parking space in the truck waiting area ( which has in the moment 220 places and was in average occupied with 212 ). In the model there was assumed, that each train supplies the same amount of containers as it transports away. This was built in the model. The trucks shall bring as well each one container. This was not built in the model and was abstracted as a "source" with a BoL. The optimization tool of the simulation software is not very helpful due to the complexity. Therefore there were 
several modifications of the model and of the input values made. This will be shown in the following chapter.

\subsubsection{Results for the modifications of the basic model described in chapter 4.1 .3}

\section{(4.1.3.1 ) : Reduction of length of YCa from 3500 meters to 1500 meters :}

There is no impact to departure times of ships, trains or trucks or to cycle times of cranes. Staytimes are similar in a statistic range. The status monitors do not have different values. The only difference shows the blockage of "Blindstrecke" in YCa, where the value increases from $67,4 \%$ ( avg, value from run $1-5$ ) to $73,2 \%$ but with no impact to the TPT values. It seems that there is no need for an extended YCa.

( 4.1.3.2 ) : Extension of the length of the YCa from $3500 \mathrm{~m}$ to $21500 \mathrm{~m}$ :

There is a negative impact to the finished loading of the ships. The time is increasing for ship 1 from $20,21 \mathrm{~h}$ to $21,5 \mathrm{~h}$ and for ship 2 from $20,44 \mathrm{~h}$ to $21,9 \mathrm{~h}$. The utilization of the QC is reduced by $2 \%$. The blockage of the YCa is decreasing from $67,4 \%$ ( avg of basic model ) to $23,8 \%$. This means that there is on the carrousel a more constant flow. But this is not important for the overall process. The avg. TPTs of the containers to trains is increased for railtrack 1, 2 from $86,7 \mathrm{~min}$ to $108 \mathrm{~min}$ and for railtrack 3, 4, 5 from 50,7 min to $103 \mathrm{~min}$. The reason therefore is, that the blockage in the $\mathrm{TCa}$ has dramatic 
increased from $8,7 \%$ to $62,6 \%$. Nethertheless the last train could leave 0,36 hours earlier. The avg. TPT for the trucks is 50 min longer, which has an effect for the containers that are shipped direct. For the containers which have been delayed, there is no impact. In the basic model each container was circling on the YCa nearly twice in avg. Now only $50 \%$ of the containers are going twice on the YCa. The ST in the transportation system to satellite 1 increases from 156 minutes to 205 minutes. The rolling warehouse is transferred from the $\mathrm{YCa}$ to the transportation system to satellite 1 and to the TCa. The conclusion is, that an extended YCa does not make sense, it will only cost money and does not have any benefit to the overall tranfertime.

( 4.1.3.3 ) : Extension of the length of the YCa to $21500 \mathrm{~m}$ and double speed in all . transportation systems ( from $5 \mathrm{~m} / \mathrm{s}$ to $10 \mathrm{~m} / \mathrm{s}$ and from $9 \mathrm{~m} / \mathrm{s}$ to $18 \mathrm{~m} / \mathrm{s}$ ) :

There is still a negative impact to the loading time of the ships. It takes a half hour more than in the basic model. The blockade of the YCa is further reduced to $13,6 \%$. The TPT for the trains and for the direct loaded trucks are now reduced, but still higher than in the basic model. There is a high increase of the circling containers in the YCa. Now the containers are in avg. nearly 3 times (!) circling before they leave the $\mathrm{YCa}$ for their destination. This cannot be the strategy, as there is no benefit in the overall transfer time. The TCa ist still blocked during $42,7 \%$ of the time. The ST of the containers in the transportation system to satellite 1 is with 174 min as well higher than in the basic model. 
( 4.1.3.4 ) : Basic model with constant speed of $5 \mathrm{~m} / \mathrm{sec}$ in all transportation systems :

There is no impact to the overall transfer times. The values are in a statistic range similar to basic model. The speed has no influence to the results. In consequence the speed reduction can save energy.

( 4.1.3.5 ) : Basic model but with 30 administration desks and double truck loading stations :

As there are in avg. about 300 containers in the transportation system, a faster throughput through administration and truckloading has no impact to ship unloading/loading time, to the YCa structure and to the train processes. The big effect is, the reduction of the blocked time in the transportation system to satellite 1 . There is only $1,9 \%$ of the time blocked vs. $68,4 \%$ in the basic model. The avg, ST in the system is only 9,3 minutes vs $156 \mathrm{~min}$ in the basic model. In avg there are only 20 containers in the system, i.e. it is empty. The administration desks increase their idle time to $32,5 \%$. In theory we have an overcapacity of $50 \%$. Due to the delayed containers ( quarantine and shipping window ) there is a reduction for the last truck, leaving from $31,99 \mathrm{~h}$ to $26,7 \mathrm{~h}$. For the direct loaded containers to trucks, the avg. TPT is reduced to 22,7 minutes ( $\mathrm{bm}: 209,3 \mathrm{~min}$ ).This is big progress, but requires a double investment in infrastructure of the satellite. For the practical operation it may be a problem as peaks in utilization of the loading station will appear, which are questionable in an economic view. 
( 4.1.3.6 ) : Basic model but with 30 administration desks and triple truck loading stations:

There is no significant difference to the (4.1.3.5) model. The idle time at the administration desk is further increased to $34,2 \%$. Therefore is no need to triple the capacity.

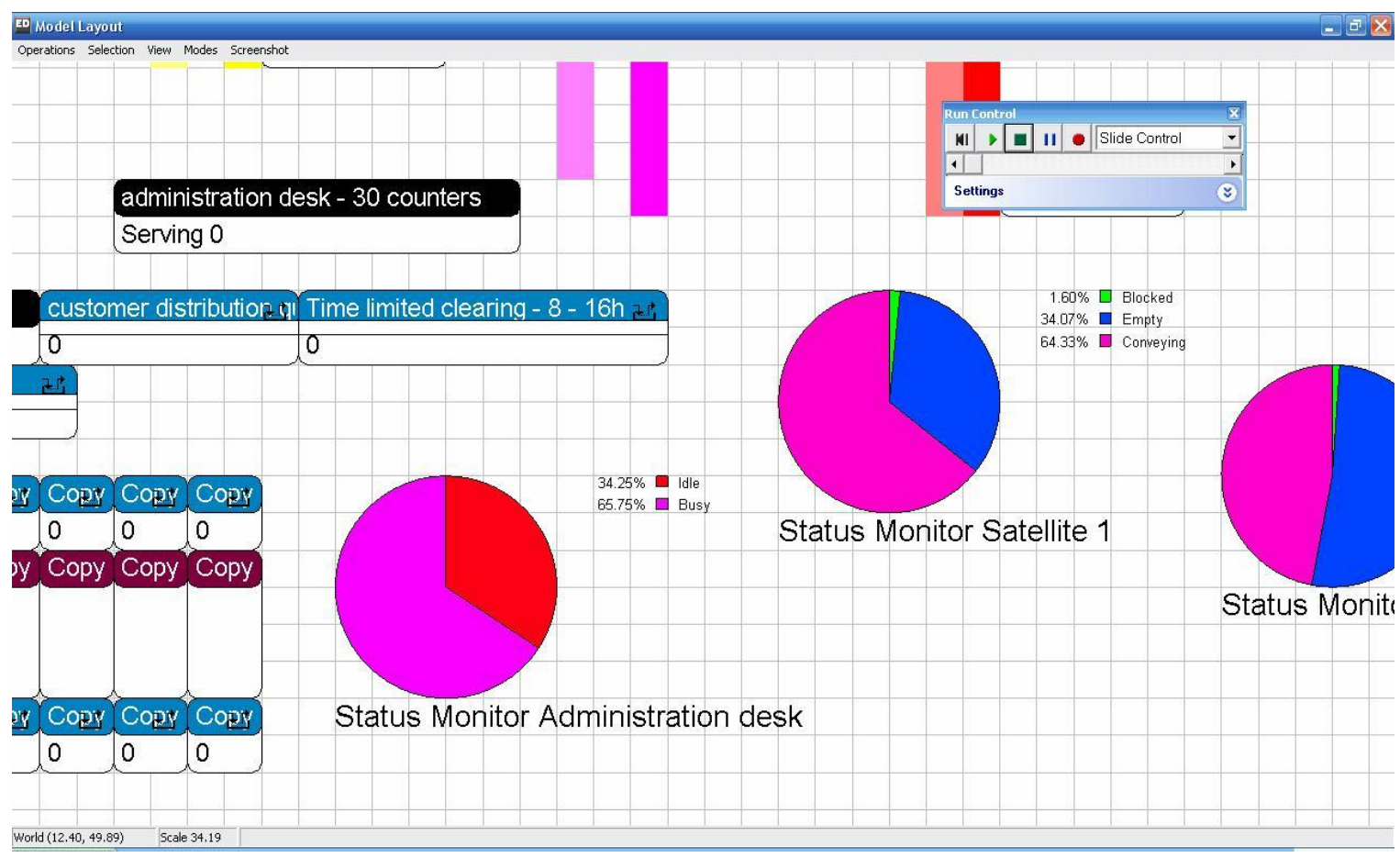

Figure 48 : SM of administration and SM satellite 1 with small blockade ( 30 counters and triple truck loading docks ) 


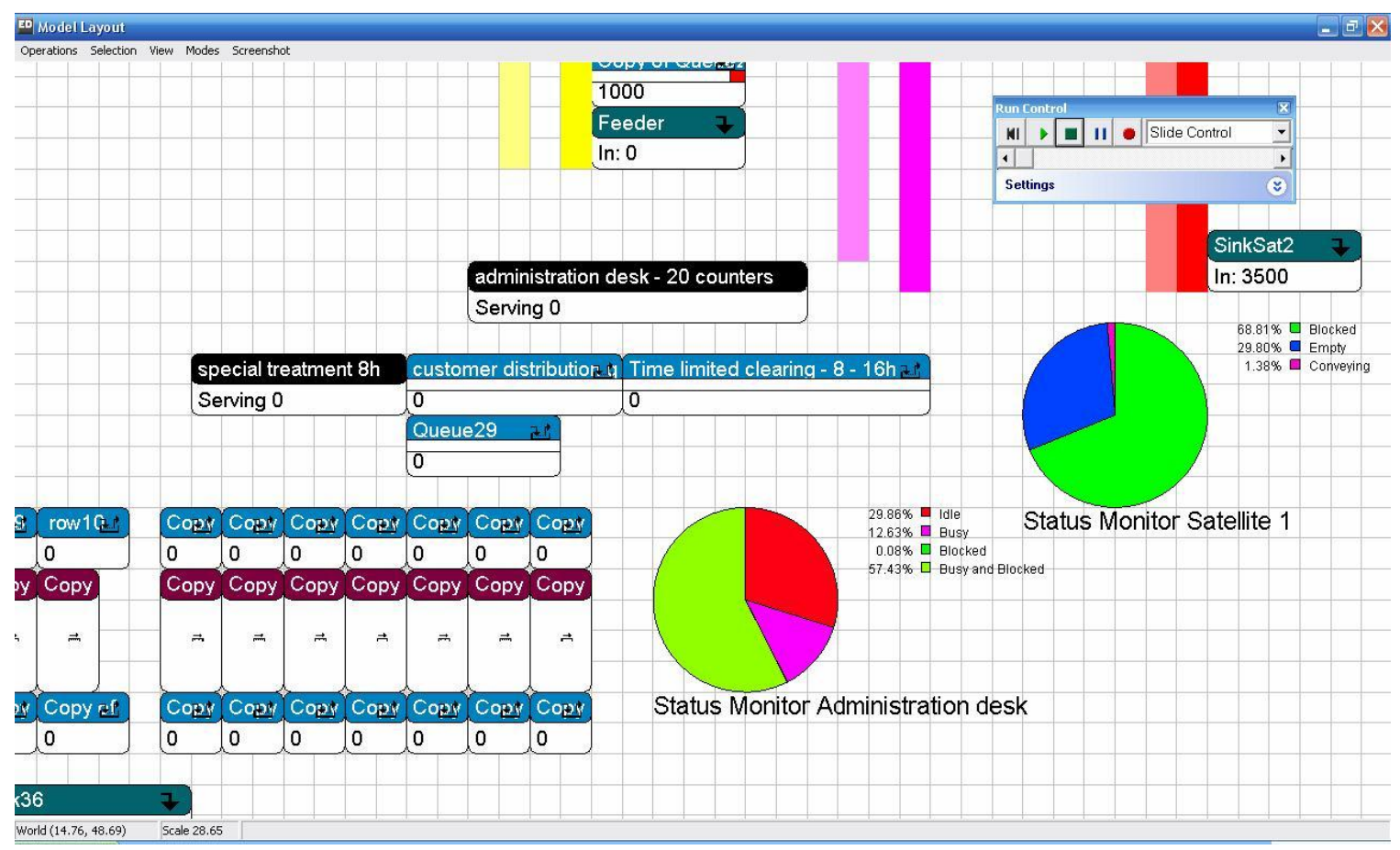

Figure 49 : SM of administration and SM satellite 1 of the basic model

The two Figures $(48,49$ ) show the big influence of the truck loading capacity to the efficiency of the satellite system.

( 4.1.3.7 ) : Basic model but with 30 administration desks and without quarantine and without shipping window ( all containers ready for direct loading to trucks) :

The result is, that the last truck is loaded after 31,2 hours ( basic model : 31,99 hours). This is not a surprise, as the bottleneck is the capacity of the truck docking stations. The increase of the administration counters has no impact. The avg. ST of the containers in the transportation system to satellite 1 is increased to 346 min (basic model : 156 min ) and the administration $\mathrm{ST}$ is increased to $15,1 \mathrm{~min}$ (basic model : 7,6 $\mathrm{min}$ ). The 
conclusion is, that the increase of the direct go through of about $30 \%$ is to high for the installed capacity of the truck loading area and is blocking the processes at the administration.

( 4.1.3.8 ) : Basic model but with 30 administration desks and the double capacity of the truck loading docks without quarantine and shipping window :

There is no impact to ship loading and train loading times. The truck loading process is now finished after 18,5 hours. The ST in the transport system to satellite 1 is reduced to 12 minutes. There is a direct flow of the containers to the docks. The avg. administration ST is reduced by 1 minute towards the basic model which shows a gain of efficiency. The conclusion is that a variable capacity in the loading process has an impact to the TPT. In average the TPT for the truck loaded containers is 26 minutes and the maximum TPT is 47 minutes ( basic model direct loading : 209 minutes ). There is room for optimization, but this capacity has to be adapted to the unloading/loading capacity. 


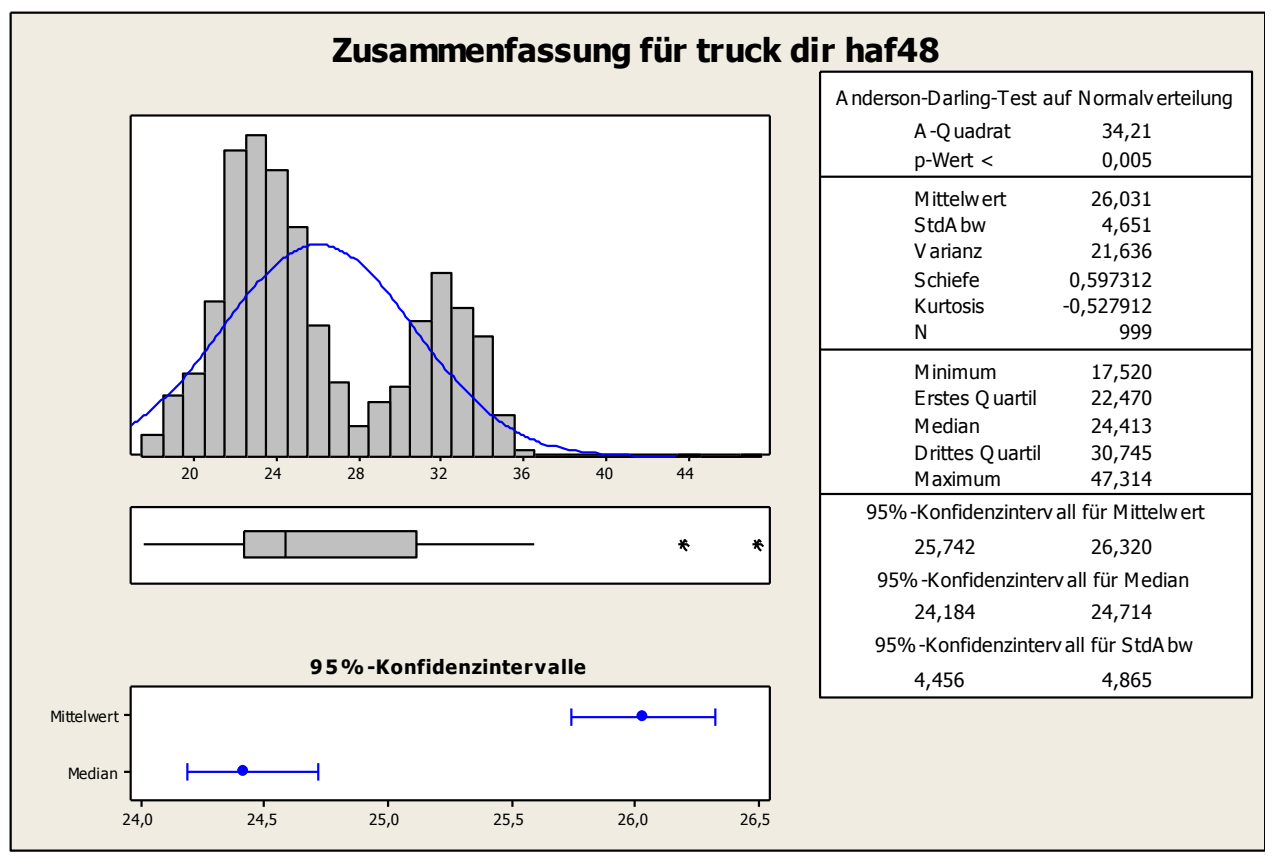

Figure 50 : TPT distribution for containers to satellite 1 truck loading

(4.1.3.9) : Basic model with disturbances at the $\mathrm{YCa}$, transportation systems to trainstation and to satellite 1 and TCa :

The disturbances are implemented into the basic model as followed :

- transportation systems to train und to satellite 1 :

first breakdown after : $3 \mathrm{~h}$

meantime to failure $: 5 \mathrm{~h}, 1 \mathrm{~h}$ ( $\log$ Normal distribution $)$

meantime to repair : $45 \mathrm{~min}, 10 \mathrm{~min}$ ( $\log$ Normal distribution )

- $\mathrm{YCa}$ :

first breakdown after : $4 \mathrm{~h}$

meantime to failure : $5 \mathrm{~h}, 1 \mathrm{~h}$ ( lognormal distribution ) 
meantime to repair : $15 \mathrm{~min}, 2 \mathrm{~min}$ ( $\log$ Normal distribution )

- $\mathrm{TCa}$ :

First breakdown after $5 \mathrm{~h}$

Meantime to failure : $4 \mathrm{~h}, 1 \mathrm{~h}$ ( lognormal distribution )

Meantime to repair : $30 \mathrm{~min}, 5$ minutes ( lognormal distribution )

- QC and TC have in each model the same disturbance.

The major impact of the disturbances is the general delay of finished loading time. Ship 1 has finished loading after 21,3 $\mathrm{h}$ ( 20,21 $\mathrm{h}$ in the basic model ). Ship 2 has finished after $22,98 \mathrm{~h}(20,44 \mathrm{~h}$ in basic model $)$. The last train leave after $20,3 \mathrm{~h}(18,04 \mathrm{~h}$ in basic model ). For the truck loading there is no impact. It is to assume that the line after the administration is filled so the interruption can be covered. The utilization of the QC drop to $81,6 \%$ ( $92,2 \%$ in basic model ). The utilization of the TC drop by $6 \%$. The TCa is less busy and it is empty during $42,4 \%$ of the simulation time ( $15,4 \%$ in the basic model ). The disturbances are estimated on a real experience. It is unlikely that equipment has a breakdown of some hours or even days. If this would be the case, the whole system will not work. Service of the equipment and repetitive control elements are important.

\section{( 4.1.3.10 ) : Basic model without QC 5 :}

QC 5 is related to ship 1. After $24,52 \mathrm{~h}$ the ship is loaded complete. This is a delay of 4,3 h against the basic model. Ship 2 has finished loading after 20,65 h, which is slightly longer $(0,22 \mathrm{~h})$ than in the basic model. As the unloading process is delayed with the same time, the loading processes of the trains and trucks are delayed as well. The last 
container of ship 1 is unloaded after $22,4 \mathrm{~h}$, so the last train will not leave $22,6 \mathrm{~h}$. For the last truck loading, there is no impact.

( 4.1.3.11 ) :Basic model without QC 4 and without QC 5 (ship 1 has only 3 cranes) :

For ship 1 it takes now 30,16 h for unloading and 31,2 h to finish loading. For ship 2 has this delay consequences. The YCa is blocked by containers, waiting to be loaded into ship 1 . So ship 2 is finished after $26,2 \mathrm{~h}$, which means a delay to the basic model of $5,8 \mathrm{~h}$. It is obvious, that the trains and the trucks will need additional time.

\section{(4.1.3.12) : Modalsplit 2}

The challenge is to manage the double amount of containers to transport by train. The first attempt ( 4.1.3.12.1 ) with the basic model failed. The YCa, the transportation system to trainstation and the TCa were overfilled and even the QC stopped working. QC was $95,7 \%$ blocked and nothing moved. 


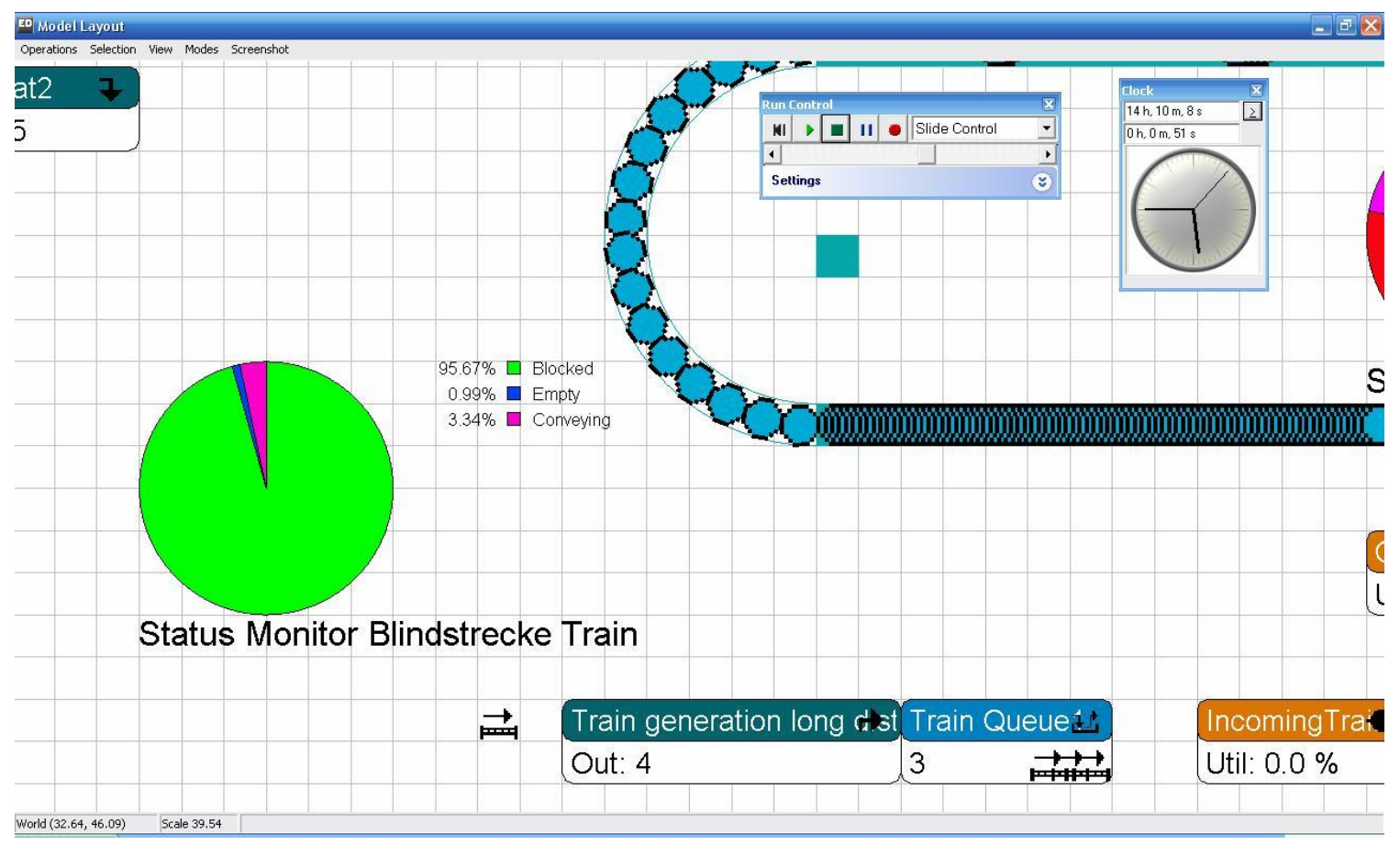

Figure 51 : Complete blockage at train station

Then the second attempt (4.1.3.12.2 ) started with the extension of the YCa to 21500 meters. Now the model was working. With the given capacity of the train station ( 5 railtracks, 3 TC ) the last train leave after $37,07 \mathrm{~h}$, which could be expected. For the truck related transportation to satellite 1 and to the docking stations there is an expected reduction of the TPT ( direct flow : 37 min to 209 min of the basic model ). The TPT of the containers to the trains have a big increase from $86,7 \mathrm{~min}$ ( avg. of basic model in rail 1,2 ) to $401,3 \mathrm{~min}$. For rail 3, 4, 5 there is a double TPT ( $199 \mathrm{~min}$ ). This gives the impression, that there are a lot of blockades in the system, which extends the throughput. This is confirmed by the analysis of the TCs, which are about $10 \%$ blocked and about 40 $\%$ idle. In consequence it does not make sense to double the volume with an existing infrastructure and given capacity. In this case it is to recommend adding additional 
railtracks. As the trains have to be unloaded simultaneous, the vessels cannot leave earlier and leave nearly together with the last train

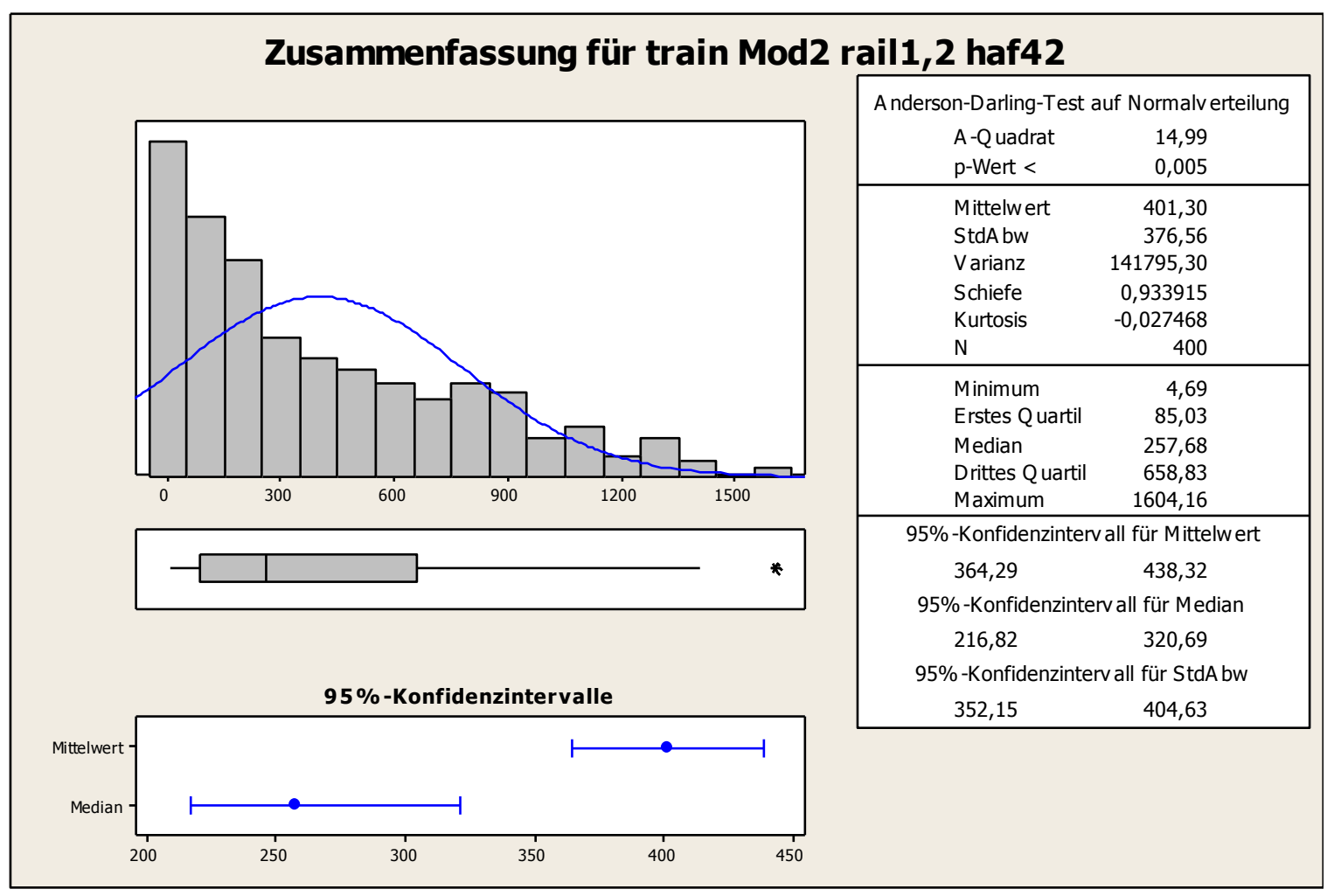

Figure 52 : TPT for containers to railtrack 1, 2 in modalsplit 2 


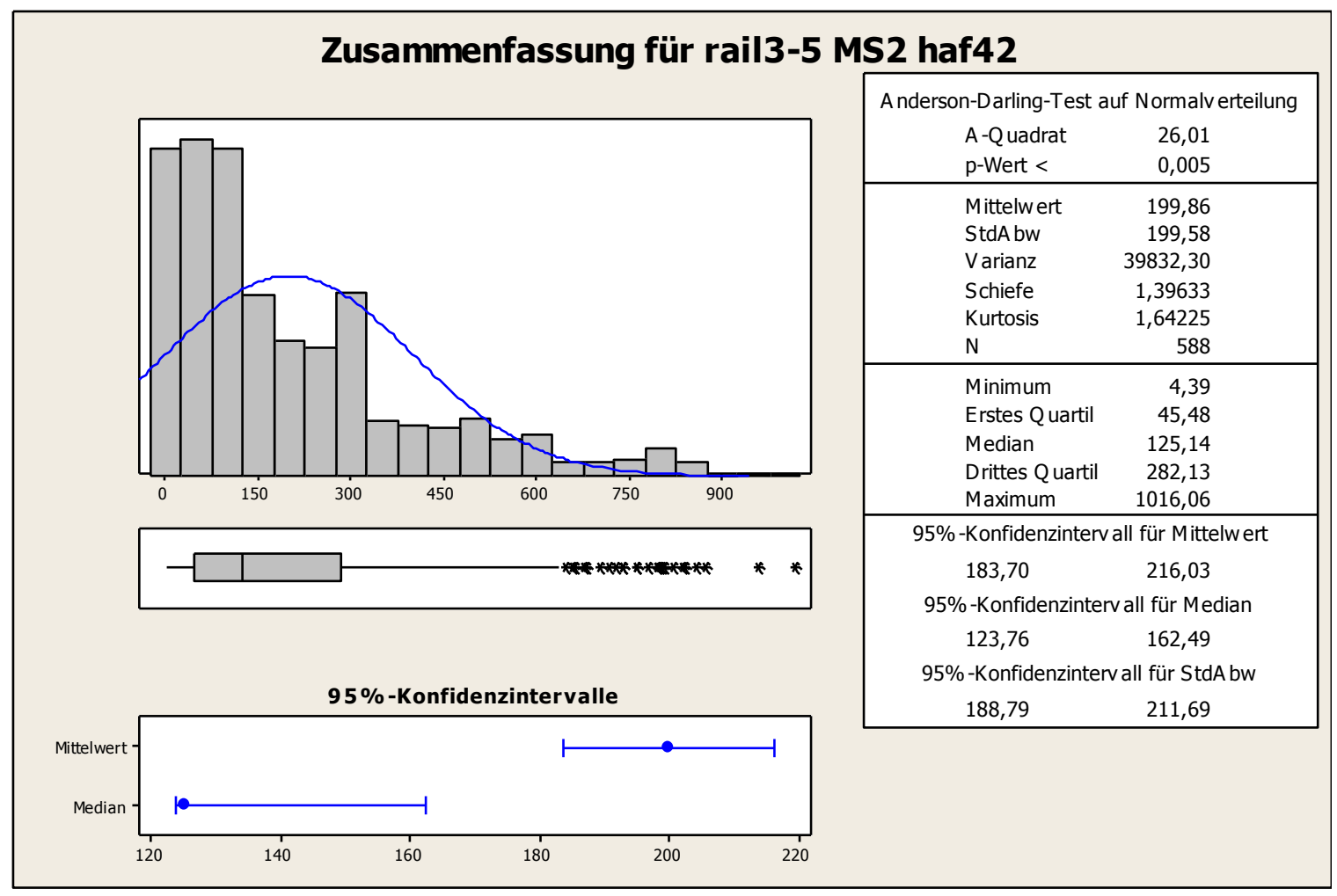

Figure 53 : TPT for containers to railtrack 3 - 5 in modalsplit 2

\section{(4.1.3.13) : Modalsplit 3 :}

In this case the same experience was made with the basic model like in the modalsplit 2 case. A total breakdown of the model with YCa length of $3500 \mathrm{~m}$. Then the YCa was extended to $21500 \mathrm{~m}$. For the truck line there is no impact. The ship loading timeline is roughly the same as in the basic model. Of course the last train leaves after $42,12 \mathrm{~h}$, because 10 additional trains have to be generated. Another conclusion is that the infrastructure of the TCa must be increased, as there is a blockage, which has an impact to the $\mathrm{YCa}$ and the transfer to the satellite, because even with the lower modalsplit truck, the TPT direct truck shipment is increasing slightly. Expected was a reduction. 


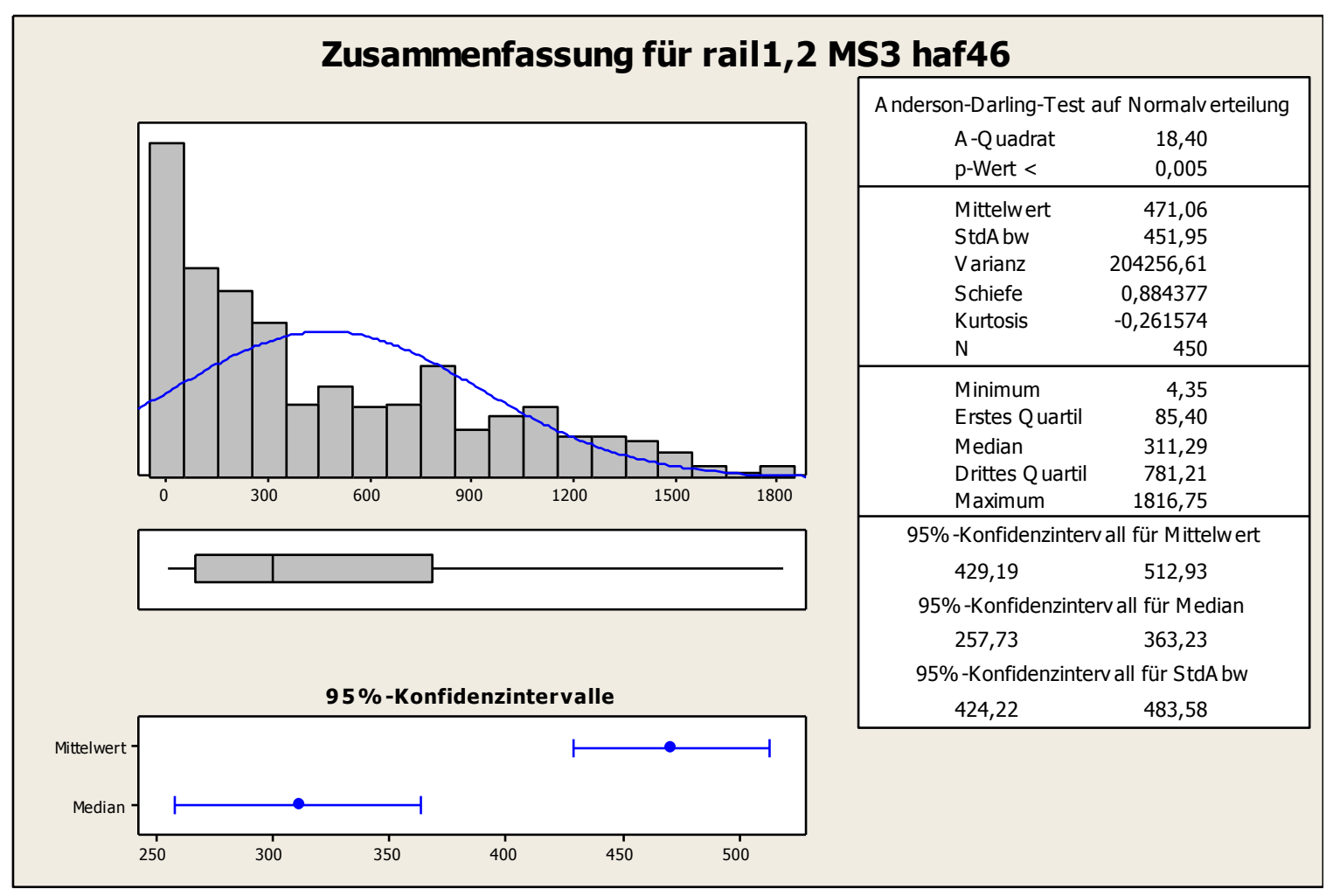

Figure 54 : TPT for railtrack 1. 2 in modalsplit 3 


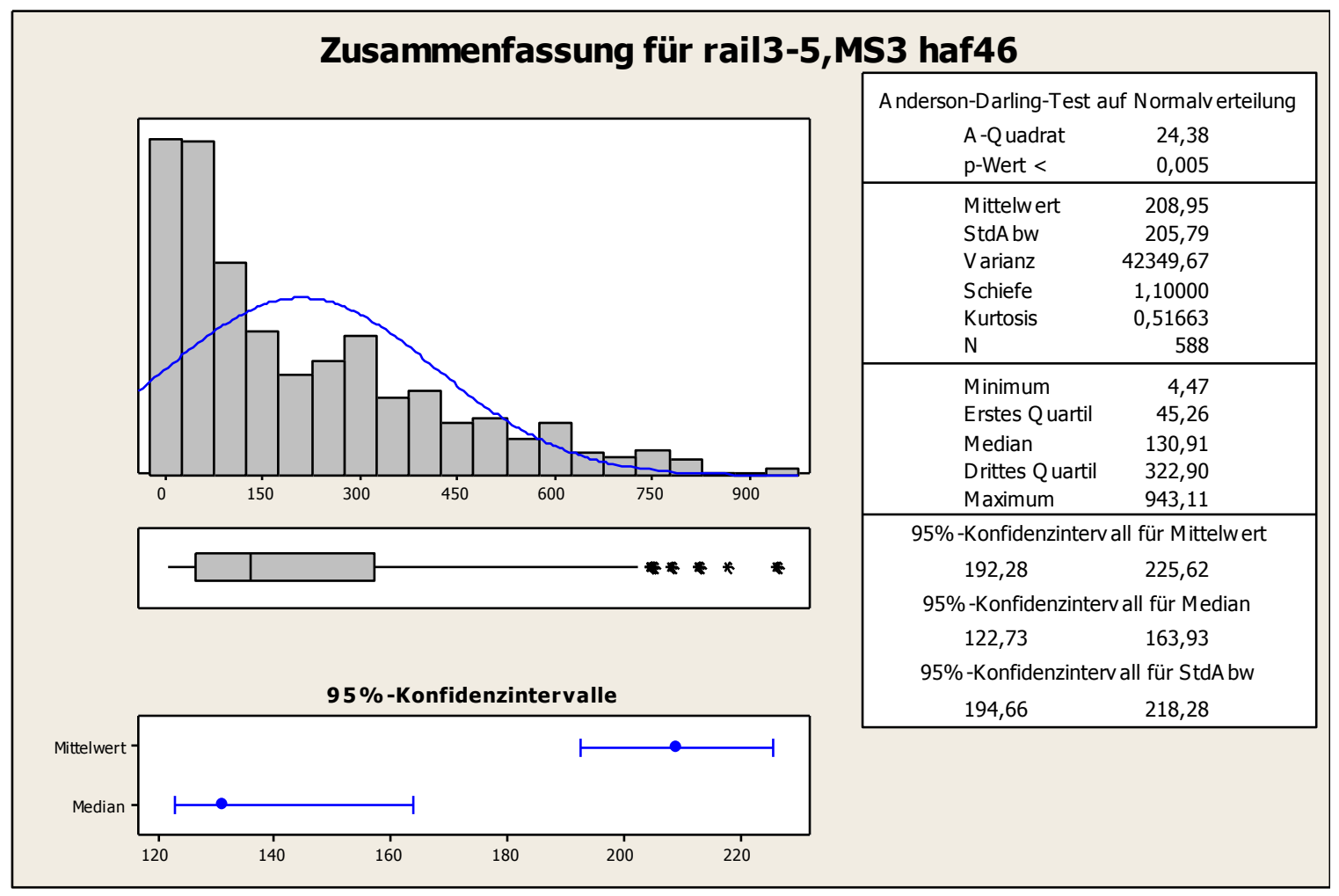

Figure 55 : TPT for railtrack 3 - 5 in modalsplit 3 


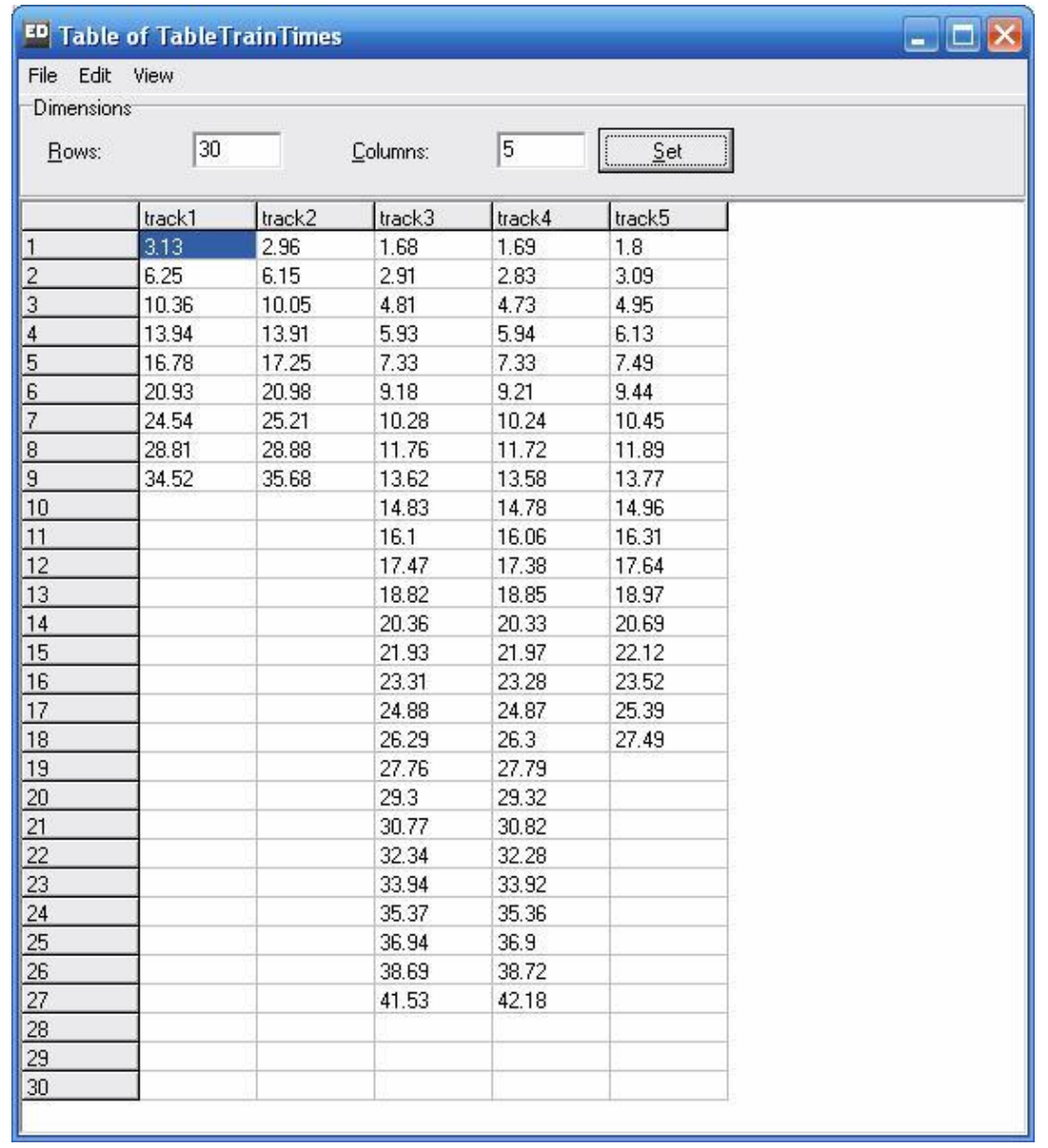

Figure 56 : Train departure times in modalsplit 3

The TPT of the containers to train are again higher. For the railtracks 1, 2 the avg. value is now $471 \mathrm{~min}$ and for rail 3, 4, 5 now $208 \mathrm{~min}$. The utilization of the TCs is similar low as in modalsplit 2. The vessels leave together with the last train. 


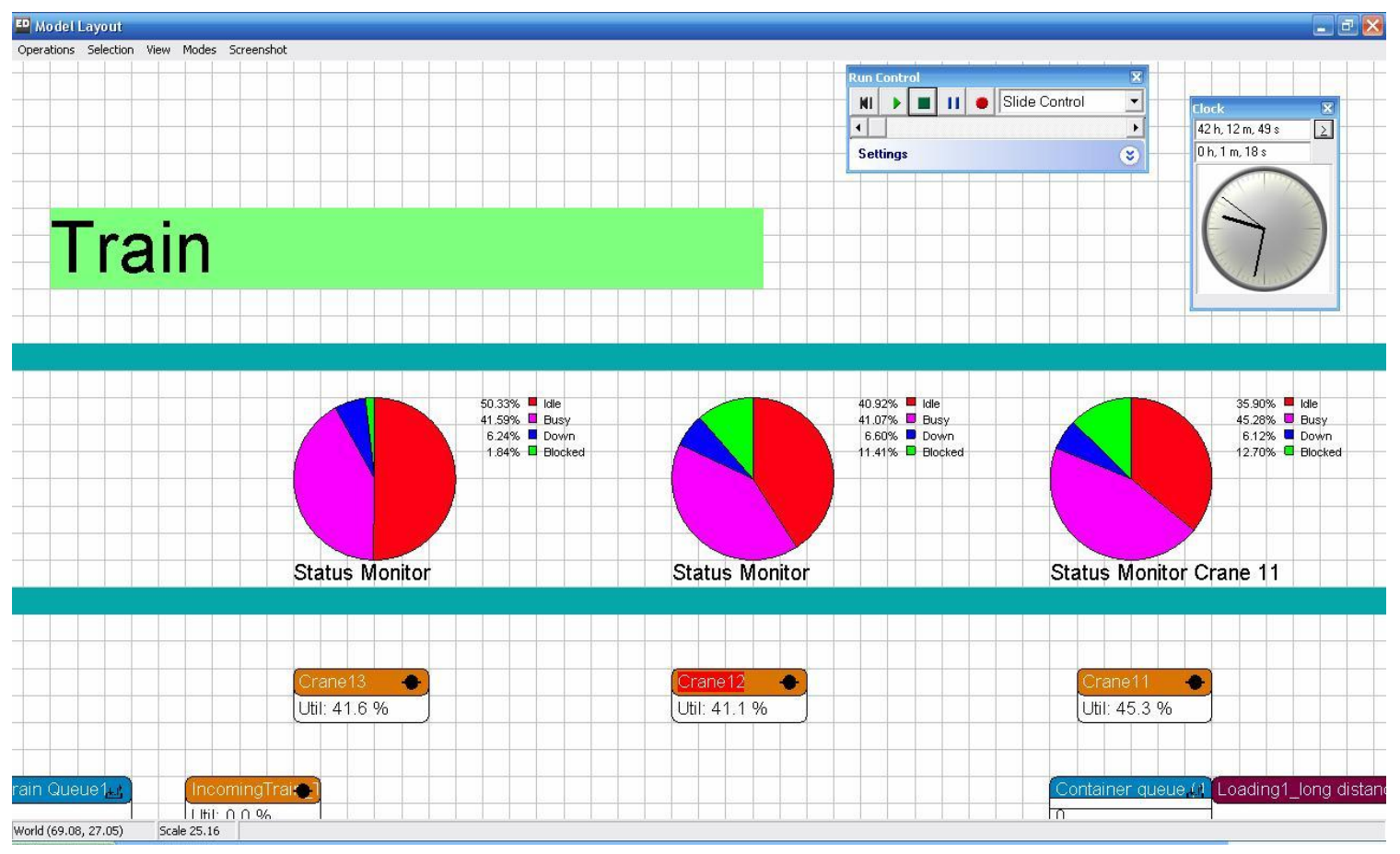

Figure 57 : SM for the TC show a low utilization in modalsplit 3

Conclusion to the situation of modalsplit 2 and 3 is, that there is a need of increasing the infrastructure at the trainstation ( increase the number of railtracks, to boost the overall capacity ). Another conclusion is, that the infrastructure of the TCa must be increased ,as there is a blockage ( see the quite high idle time of the TCs ), which has as well an impact to the YCa and to the transfer to the satellite, because even with the lower modalsplit for trucks, the TPT direct is increased. 
Table 9 : Overview about the modifications.

\begin{tabular}{|c|c|c|}
\hline Number & Modification of bm & Results \\
\hline$(4.1 .3 .1)$ & $\begin{array}{l}\text { reduction YCa from } \\
3500 \mathrm{~m} \text { to } 1500 \mathrm{~m}\end{array}$ & $\begin{array}{l}\text { no impact to departure time and TPTs } \\
\text { blockage increase of } \mathrm{YCa}\end{array}$ \\
\hline$(4.1 .3 .2)$ & $\begin{array}{l}\text { extension YCa from } \\
3500 \mathrm{~m} \text { to } 21500 \mathrm{~m}\end{array}$ & $\begin{array}{l}\text { increase of departure time ships } \\
\quad \text { - } \quad \text { ship } 1:+1,29 \mathrm{~h} \\
\text { - } \quad \text { ship } 2:+1,46 \mathrm{~h} \\
\text { QC utilization reduced by } 2 \% \\
\text { blockage YCa decreased from } 67,4 \% \text { to } 23,8 \% \\
\text { increase of TPTs for train and truck containers } \\
\text { no solution for the entire process chain }\end{array}$ \\
\hline$(4.1 .3 .3)$ & $\begin{array}{l}\text { extension of YCa from } \\
3500 \mathrm{~m} \text { to } 21500 \mathrm{~m} \\
\text { double speed of all transportation } \\
\text { systems }\end{array}$ & $\begin{array}{l}\text { increase of departure times for both vessels } \\
\qquad \quad+0,5 \mathrm{~h} \\
\text { blockage further reduced to } 13,6 \% \\
\text { TPTs still higher for train and truck containers } \\
\text { no benefit for the entire process chain }\end{array}$ \\
\hline (4.1.3.4) & constant speed of $5 \mathrm{~m} / \mathrm{sec}$ & $\begin{array}{l}\text { no impact to departure times of ships or to TPTs } \\
\text { speed reduction can save energy }\end{array}$ \\
\hline (4.1.3.5) & $\begin{array}{l}30 \text { administration desks } \\
\text { double truck loading capacity }\end{array}$ & $\begin{array}{l}\text { no impact to ship departures } \\
\text { reduction of the avg.TPT truck direct loading from } \\
209,3 \mathrm{~min} \text { to } 22,7 \mathrm{~min}\end{array}$ \\
\hline$(4.1 .3 .6)$ & $\begin{array}{l}30 \text { administration desks } \\
\text { triple truck loading capacity }\end{array}$ & no significant difference to to $(4 \cdot 1.3 .5)$ \\
\hline$(4.1 .3 .7)$ & $\begin{array}{l}30 \text { administration desks } \\
\text { no quarantine } \\
\text { no shipping window trucks }\end{array}$ & $\begin{array}{l}\text { last truck is leaving after } 31,2 \mathrm{~h}(\mathrm{bm}: 31,99 \mathrm{~h}) \\
\text { no impact to other values } \\
\text { bottleneck is truck loading capacity }\end{array}$ \\
\hline$(4.1 .3 .8)$ & $\begin{array}{l}\text { like ( } 4.1 .3 .7 \text { ) but with } \\
\text { double truck loading capacity }\end{array}$ & $\begin{array}{l}\text { the last truck is no leaving after } 18,5 \mathrm{~h} \text {, } \\
\text { the avg. TPT truck is reduced to } 26 \mathrm{~min} \\
30 \text { administration desks are overseized }\end{array}$ \\
\hline (4.1.3.9) & $\begin{array}{l}\text { disturbances in YCa,train and } \\
\text { satellite transport systems }\end{array}$ & 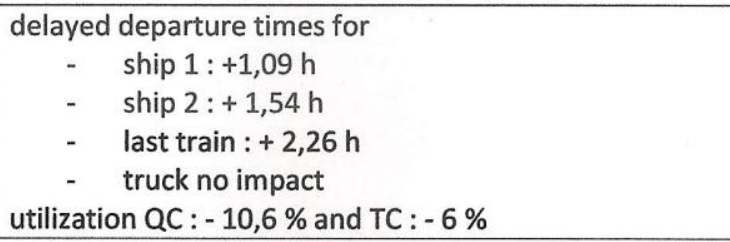 \\
\hline (4.1.3.10) & without QC 5 ( related to ship 1) & $\begin{array}{cl}\text { increase of departure times } \\
- & \text { ship } 1:+4,3 \mathrm{~h} \\
- & \text { ship } 2:+0,22 \mathrm{~h} \\
- & \text { last train }:+4,56 \mathrm{~h} \\
\end{array}$ \\
\hline$(4.1 .3 .11)$ & without QC 4 and QC 5 & $\begin{aligned} & \text { increase of departure times for } \\
& \text { - } \text { ship } 1:+10,99 \mathrm{~h} \\
&- \text { ship } 2:+5,8 \mathrm{~h} \\
&- \text { last train }:+10,5 \mathrm{~h} \\
&\end{aligned}$ \\
\hline$(4.1 .3 .12)$. & $\begin{array}{l}\text { modal split } 2 \text { and extended YCa } \\
\text { from } 3500 \mathrm{~m} \text { to } 21500 \mathrm{~m}\end{array}$ & $\begin{array}{l}\text { increase of departure time train } \\
\text { last train leaves }+19,03 \mathrm{~h} \text { later } \\
\text { TPT train }:+112 \mathrm{~min}\end{array}$ \\
\hline (4.1.3.13) & $\begin{array}{l}\text { modal split } 3 \text { and extended YCa } \\
\text { from } 3500 \mathrm{~m} \text { to } 21500 \mathrm{~m}\end{array}$ & $\begin{array}{l}\text { increase of departure time train } \\
\text { last train leaves }+24,08 \mathrm{~h} \text { later } \\
-\quad \text { infrastructure of train system (TCa ,rails ) must } \\
\text { be increased, }\end{array}$ \\
\hline
\end{tabular}




\subsection{TECHNICAL FEASIBILITY OF TRANSPORT SYSTEMS AND INFRASTRUCTURE.}

Most of the big harbors are working on a long-term transportation strategy, to handle the growth of the container volume. The Hamburg Port Authority (HPA) has mentioned in their "Hafenentwicklungsplan until 2025", that they are studying 20 proposals of innovative transport systems, such as MAGLEV, driverless trains, automated shuttle systems, multiple server handling systems with hanging electro monorail ( known as Concar-system developed by Thyssen-Krupp ).

\subsubsection{Unloading-Loading process in the yard or at train station or dryport terminal.}

The Concar system is described already in an article from Prof.Dr.-Ing . D.Arnold and Dipl.Wirtsch.-Ing. B.Rall, University Karlsruhe,1996 , A new handling system for freight Transshipment centers in comparison with other conceptions. ( Figure 58, Figure 59 and Figure 60 are taken out of this article ). The simulation model is based on a continuous service of the containers without any stacking and intermediate storing. The Concar system is matching these requirements perfectly, as there can be realized a parallel unloading and loading process and the containers are ready for service on the carrousel or on a buffer line. In consequence a multiple handling can be avoided. The Concar system can be applied as well in the yard and at the trainstation and as truck 
terminals in the satellite or Dryport. There is no traffic of AGVs, ALVs or Straddle Carriers. There are less interfaces of workforce and individual movement equipment, so the processes should have less disturbances and waiting time should be reduced.

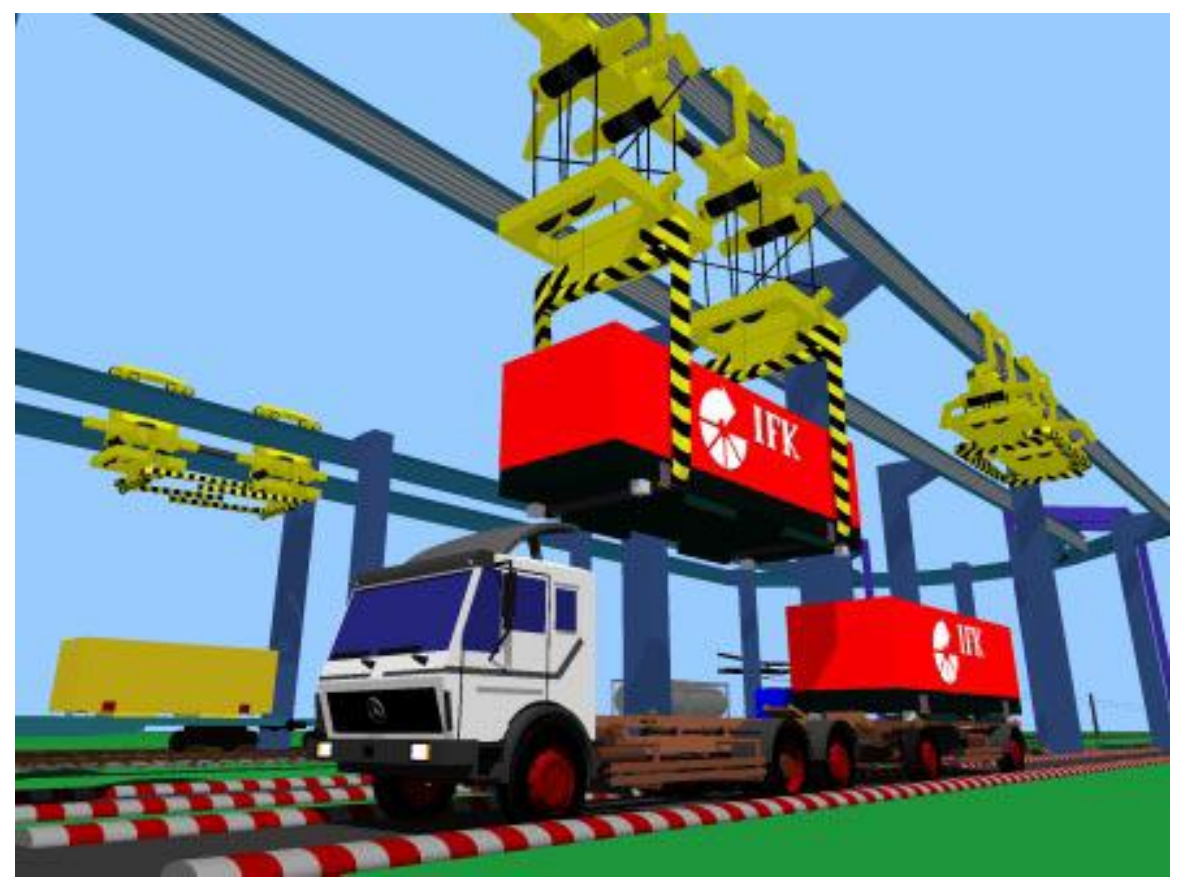

Figure 58 : Handling with electric monorail Concar with parallel movement of truck or train and the hanging multiple lift.( after D.Arnold ) 
a)

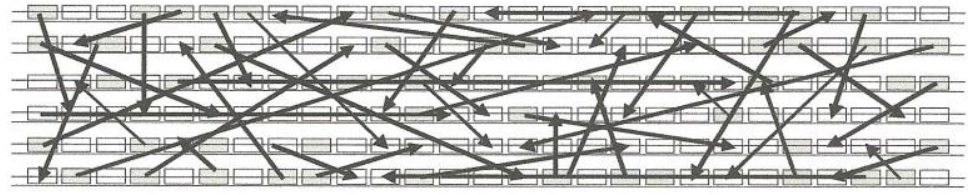

b)

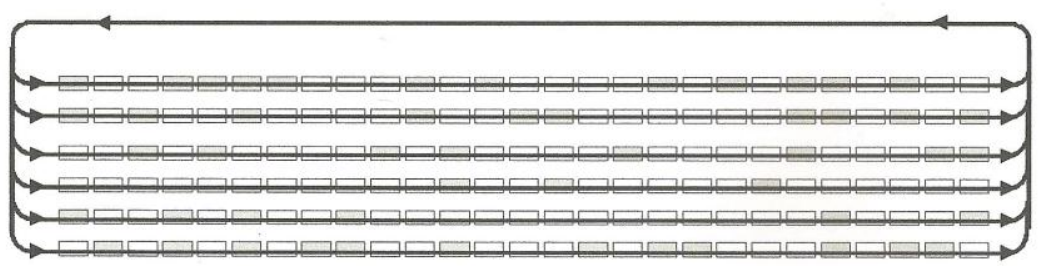

Figure 59 : Illustration of the material flows in a rail-to-rail-hub for a transtainer terminal and 6 parallel monorails (b): The upper line in (b) could be the carrousel (after D.Arnold )

The advantage is that the movements are in one direction and that several lines can be served the same time while with portal cranes the interactions of the cranes must be controled.

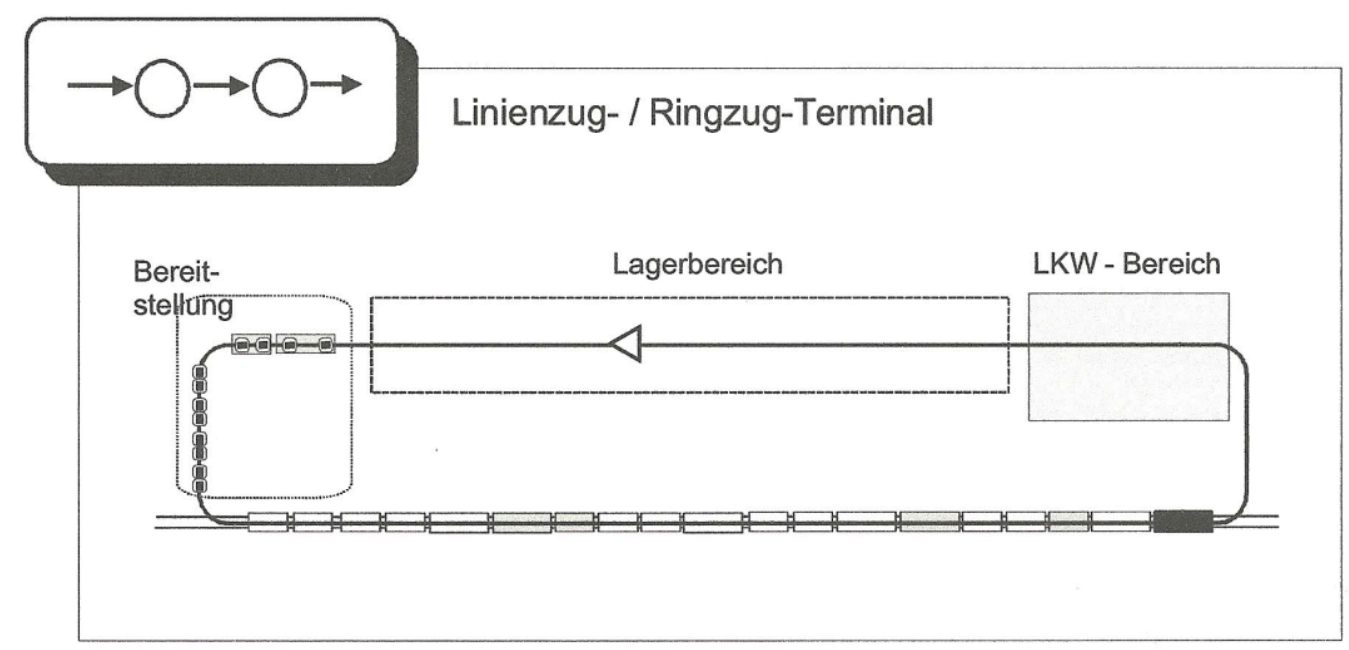

Figure 60 : Simplified layout of a Concar terminal for regular-service-trains ( after D.Arnold ) 
Figure 60 shows the possible layout of combined train/truck loading terminal. The containers can be picked up from the carrousel or from a buffer line and loaded to trucks or trains directly. With the 2 crabs followed each other one container could be unloaded and another loaded onto the empty place. Of course the layout can be modified as a train station with several rail lines or as a truck terminal with several docking lines.

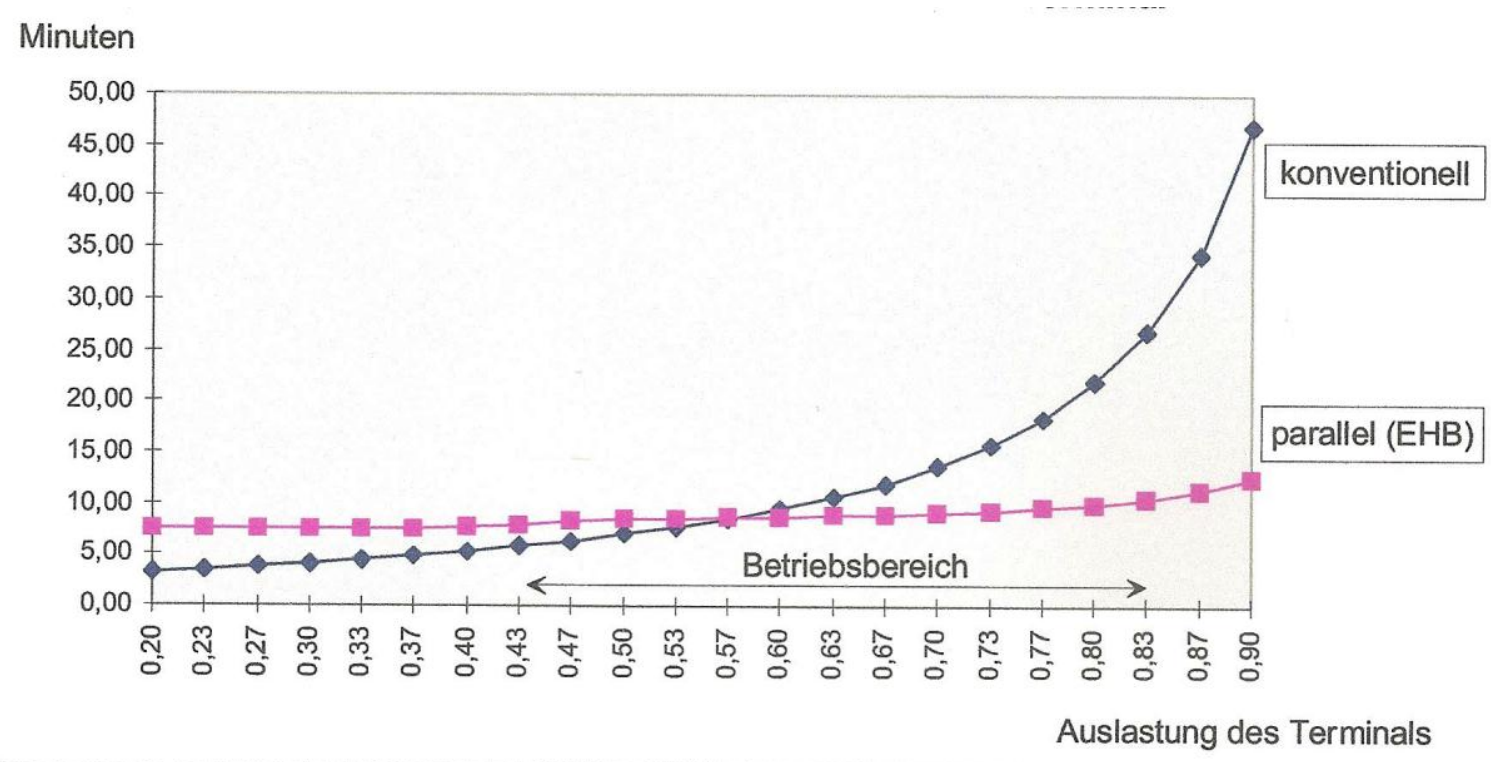

Figure 61 : Comparison of service times of single server and multiple server systems ( after Prof Arnold,)

A simulation, done in the mentioned article of Prof. D.Arnold shows that already at a utilization of the terminal of $57 \%$ the service time of a conventional single server is increasing due to waiting times caused by individual irregularities. The parallel service is nearly constant. 


\section{3..2.Transportation system to train station, satellites and feeder loading area.}

For the transportation of the containers out/into of the yard there are several possibilities in discussion. The study from the Tioga Group "Inland Port Feasability study" (2008) proposed a "Commuter" shuttle concept such as Metrolink with short trains. The advantage is, that these trains can be unloaded and loaded faster, need a much smaller terminal and can accelerate and brake faster, than a traditional double -stack freight train with a capacity of 300 fourty-foot containers. In May 2012, Dave Alba has introduced his GRID Project ( Green Rail Intelligent Development ) for the twin ports Los Angeles and Long Beach. He proposes an underground "Freight Pipeline Network" with an electric subway of containers in 2 tubes with 15 feet diameter. The pipes shall connect the ports with distribution centers far out of 60 miles from the ports. He estimates that $70 \%$ of the truck traffic can be eliminated with a major reduction of pollution. A similar project is under study in Hamburg. The idea is, to built either on surface or underground a MAGLEV ( magnetic hovertrain ), which connects the harbor to a Dryport 25 kilometer south of the harbor.

For the feeder loading and unloading process, there must be a different process found. As long as the shipper of the big container vessel and the feeder is the same company, the feeder part can be handled as in the examples of Singapore ( see page 45/46 ). If the shipper of the feeder is different, the feeder has to be loaded at several different places, which takes a lot of time and reduces efficiency. In Hamburg the big shippers are now starting negotiations to cooperate ( Hamburger Abendblatt 10.9.2013). 


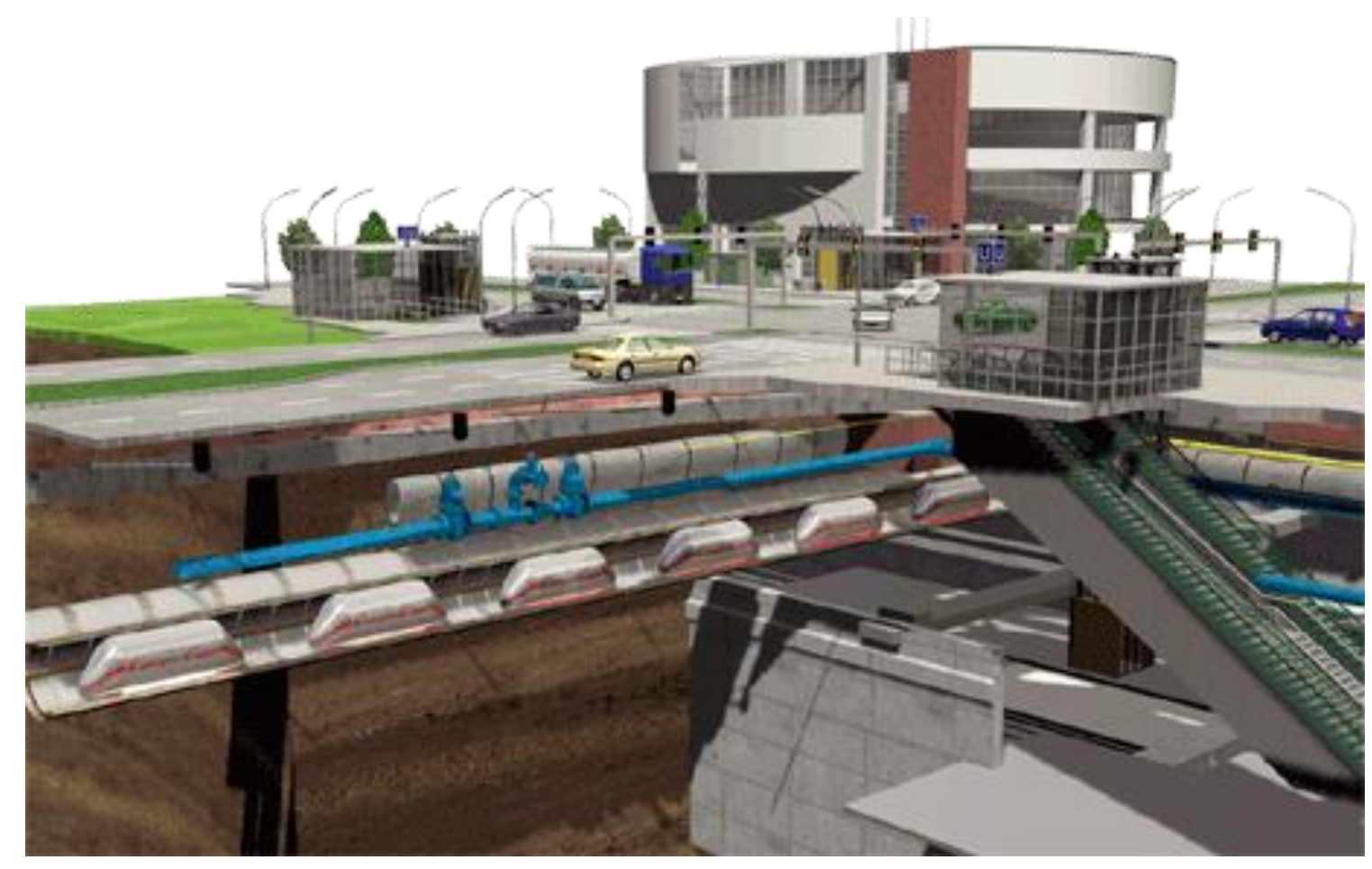

Figure 62 : Model of an underground connection.( after Cargocab,Bochum)

The German company Cargocab, Bochum has experience with automatic operating trains. Cable railways are under study as well. Kap Hwan Kim et al has proposed in the article "New conceptional Handling Systems in Container Terminals", Industrial Engineering\&Management Systems, Vol 11, No 4,2012, pp 299-309 a linear motor conveyance system ( LMCS ). All the proposals are technically feasible. The problem is the approval by public administration and the the distribution of the investment. 


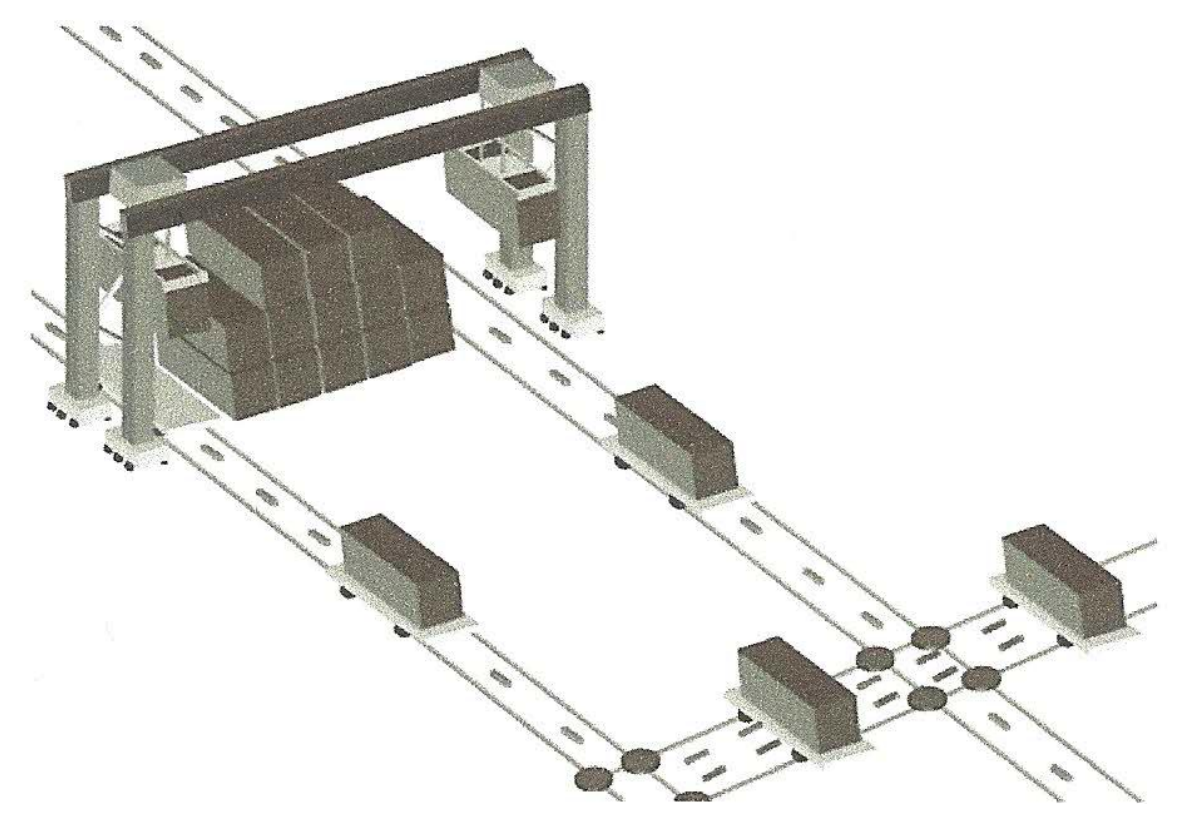

Figure 63 : Principle of LMCS.( after Kap Hwan Kim ( 2010 )

In summary, the idea of the immediate transportation without stacking in the yard, the simultaneous loading and unloading process and the satellites / Dryports seem quite feasable and have a good chance for realization in big harbors with the growing container market. The Dryport examples of smaller ports are encouraging to transfer the concept or the modifications such as satellites to big ports with a reasonable modal split to Hinterland ( trucks and train transports ). 


\subsubsection{Crane systems.}

The simulation has shown that the cycle time of QC has the major impact to the overall service time ( unloading and loading process ). To minimize this service time means to make improvements with the QCs. In the previous mentioned article of Kap Hwan Kim et.al there are three examples how to reduce the cycle time of the unloading/loading process. The following four figures are out of this article.
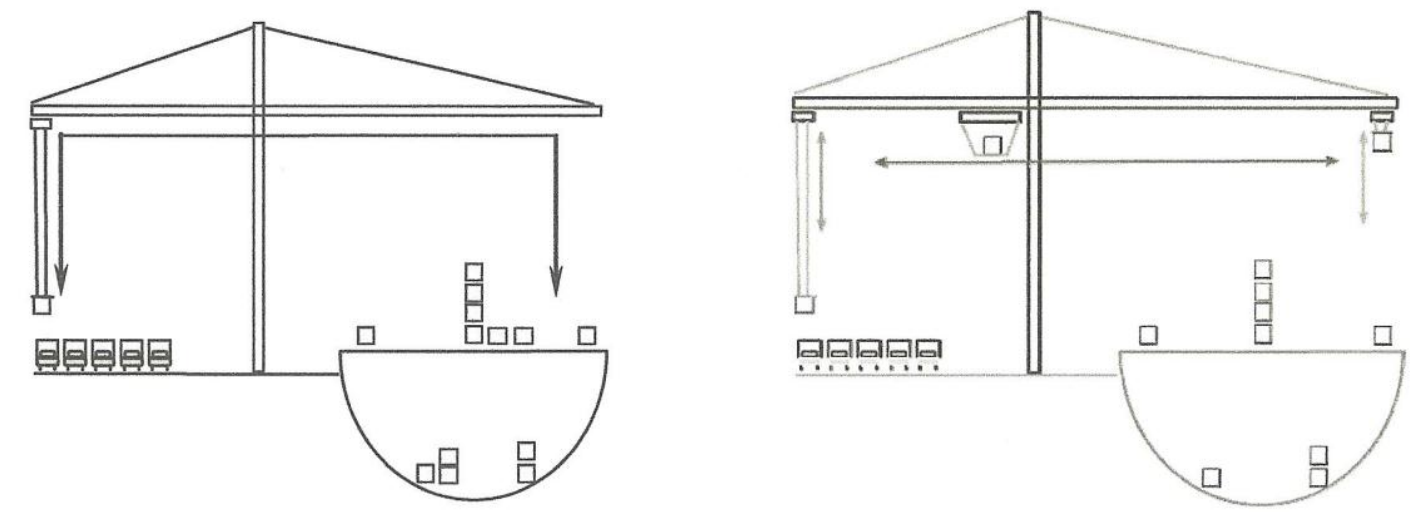

Figure 64: QC with a single spreader(crab) Figure 65 : QC with dual crabs and traverser ( after SUPERTAINER from PACECO )

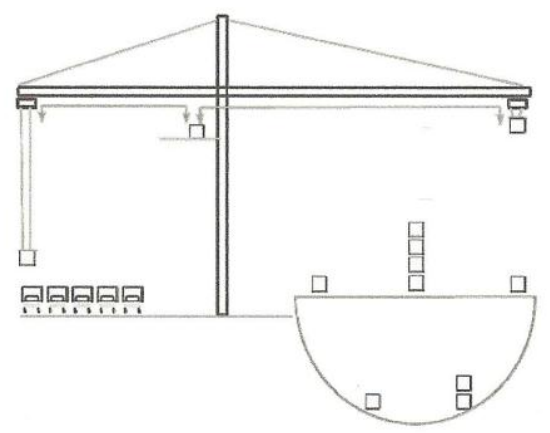

Figure 66 : QC with dual spreader

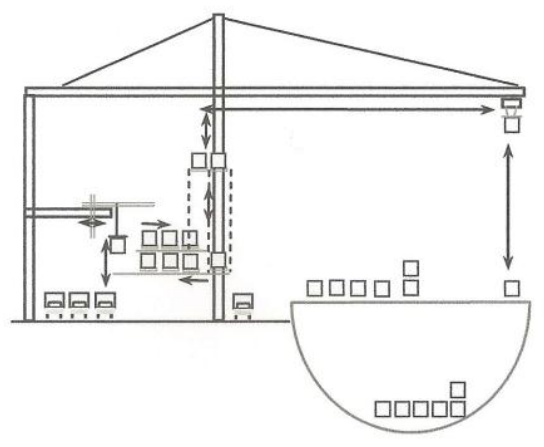

Figure 67 : QC with elevators 
All three proposals seem feasable and show possible progress in reducing cycletime. As the static structure of the cranes has to enforce slightly, the overall investment for these solutions will be economic with an acceptable payback period. 


\subsection{ECONOMIC ANALYSIS - INFRASTRUCTURE AND RUNNING COST}

\subsubsection{Infrastructure.}

The common understanding in the harbor business is that the growth of the container market cannot be handled in increasing berth length and yard area, as the space in harbor areas is limited. It is necessary to increase the overall productivity of the harbor, i.e. increase of the capacity per hectar yard and increase of the throughput at the harbor. These targets can be matched by less handling and less stacking. Todays reality is, that in the yard about five times more container are stacked than the daily amount of loaded containers. The best solution for handling the growth, is to move the containers directly out of the yard to trainstation and to satellites ( Dryports ). The focus of the proposed model and its economic analysis is, not to change the existing situation under the existing volume to handle, but to find an economic way for handling a double or triple volume, which is forcasted by market research. At the end it is a strategic view of public, political interest. The state must undertake futural planning activities to allow the economic growth and to built the public infrastructure, as the streets are already overloaded and new transportation systems may be necessary.

It is more favourable, to make an innovative infrastructure,to avoid pollution and traffic jams of the trucks. Less handling in the yard means less traffic and less pollution of the yard equipment ( $\mathrm{AGV}, \mathrm{ALV}$, straddle carrier ). In a study of a Cargo Tube from Hamburg harbor to a dryport with 25 kilometer distance, the tube has a capacity of 5 
million containers a year. The investment is estimated with 1.6 billion $€$. Considering to built additional bridges and roads, if the transportation capacity is increased with conventional solutions, the tube costs slightly more. But the economic and environmental benefit over the years will be much higher. The size of the investment seems reasonable, as in London a new fast underground railway ( Crossrail ) from East to West with two lines is under construction and will be in service successive between 2015 and 2018. The 118 kilometers need an investment of 17 billion $€$. As there are several trainstations included in the investment, the 1,6 billion $€$ seems very realistic. On the other hand, if these five million containers will be transported by truck out of the yard, there are roughly 700 trucks needed per hour. No road system will be able to handle this traffic and there would be necessary high investments in road construction and road maintenance. In Rotterdam there will be about 2 billion $€$ until 2015 spend in infrastructure. If the harbors will grow as predicted, it is of public economic interest, to prepare a transportation infrastructure such as railways etc. and Dryports, to avoid traffic jams and pollution. This is overall a strategic decision to improve competitiveness of harbors. The throughputincrease of containers out and into the yard is a major challenge, as the unloading and loading process of the ships will have a good chance to cut cycle-time by the described possibilities of crane design ( dual-spreader, elevators ). This is of major interests of the shippers, so the total service time of a ship can be minimized. In the port of Antwerp there are about 200 of these transportation vehicles ( AGV, ALV, SC, RS, forklifts ) with an estimated avg. cost of $300000 €$ each. This fleet must be doubled, if the capacity of the harbor will be doubled with traditional infrastructure. To handle this volume with the proposed yard carrousel will probably cost the same investment and save the salaries of 
the drivers ( of course to run the carrousel and to control it needs as well some workforce). In 2007 there was in the USA a "National Gateway Project" introduced, in which the effect to transfer truck transports to double-stack trains from Mid-Atlantic Ports to Midwest area was researched. One train can carry the load of 280-400 trucks. The result is the saving of 7,5 million liters of fuel and avoid 20 million tons of $\mathrm{CO}_{2}$ emissions a year. In summary there is a public investment which is strategic for state and community and there are investments in the harbour area, which follow the rules of a ROI which is reasonable in terms of economic decisions for the harbor companies. The state has the possibility to structure the modalsplit, traffic, kind of energy used in modeling laws, rules, limits of emissions and taxes. Under such conditions a lot of harbors have developed programs, to reduce individual traffic, to reduce truck travels into the yard, to reduce pollution, to use wind-energy and to give limits for combustion - pollutants ( i.e. Port of Los Angeles : the clean air action plan ( CLAA ) ). All these actions are are part of improvements of the infrastructure and have impact to the overall cost. This is the chance for changing modalsplit and to install satellites ( Dryports ). Under todays conditions ( volume, cost-structure ) a change is economic senseless. In the study "Inland Port Feasability study “, The Tioga Group, ( 2008 ) there is a model comparison made between truck and rail-shuttle transportation with consideration of infrastructure investments for a volume of 50000 containers/year. Under the current (2008) conditions the truck transport cost $300 \$$ and the rail transport $587,85 \$$ per container. With the expected cost increase of salaries, Clean Truck Plan (CTP) with licensed motor carriers the cost difference will decrease down to $47,85 \$$ which is still higher for train version. 
The model with satellites and change of modal split has only an economic advantage if constraints are changed :

- tremendous growth of the the container volume to be handled forces faster throughput

- demand of reduction of pollution in harbor area and increase of fuel cost

- limit of road capacity reached and long waiting time for trucks

- consideration of the entire supply chain in terms of cost and timing

\subsubsection{Running cost.}

The running cost have different factors along the whole supply chain :

- fixed cost of the vessel

- variable cost of the vessel

- overall service time of the vessel (unloading and loading time)

- terminal expenditure cost structure (labour today : $53 \%$ )

- terminal handling charges

- yard handling cost

- transportation cost to satellite ( dryport ) and final destination by truck 
- transportation cost to train-station and to DC and final destination by truck

The fixed cost of big vessels are mainly determined by capital cost of the ship (financed by fund and capital cost of the containers. From a seize of more than 4000 TEU the production cost per TEU is nearly constant (about $10000 € / \mathrm{TEU}$ ). The reason is, that the costs are increasing with the surface of the ship. To double the number TEU needs only an surface increase of $60 \%$. The cost per container is nearly the same like the unit cost of the vessel. The cost for workforce is with seizes > 2000 TEU constant, because only 24 people are necessary independent of the seize of the vessel ( see A.Schönknecht, 2007 ). In total the fixed cost are between 9 and $11 € /$ TEU day. This seems not very high, but for a container vessel with 10000 TEU the fixed cost are between 90000 and $110000 €$ per day. So it is in interest of the shipper, to keep the staytime in the harbour as short as possible. Figure 68 shows the cost-structure dependent on the seize of the vessels. 


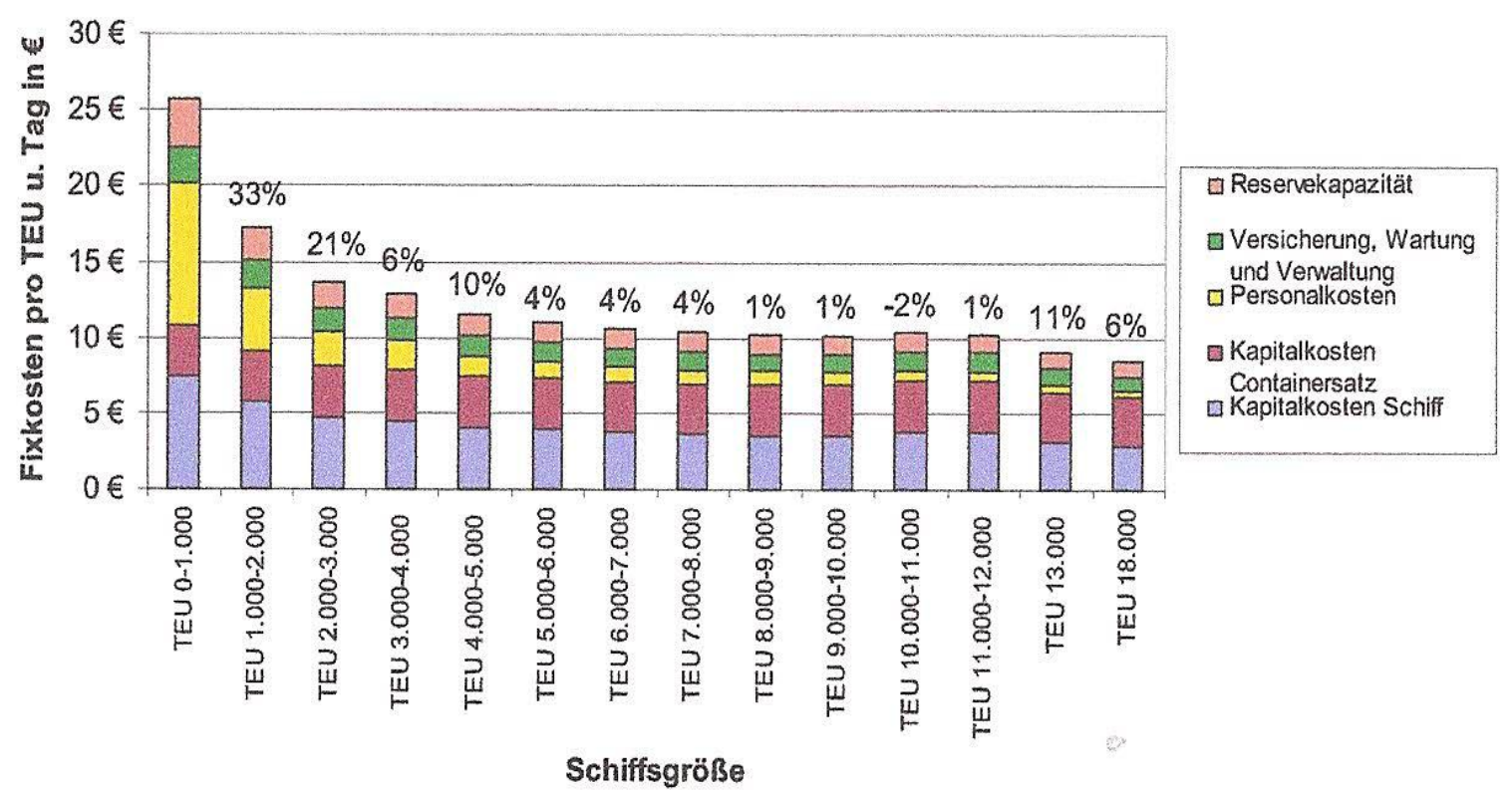

Figure 68: Fixed cost per TEU and per day dependent of the seize of the vessel ( after A.Schönknecht. ( 2006 )

The variable cost (Figure 73 ) show not a clear rule. The reason is probably the not linear engine power and different fuel consumptions. There is further an impact of the speed. Higher speed means earlier arrival of the containers at their destination but higher fuel consumption and therefor higher cost. On the other hand, if the shipper is short in capacity ( good economic situation ) he may have an interest to increase the transportation throughput of his vessel and will run with higher speed. 


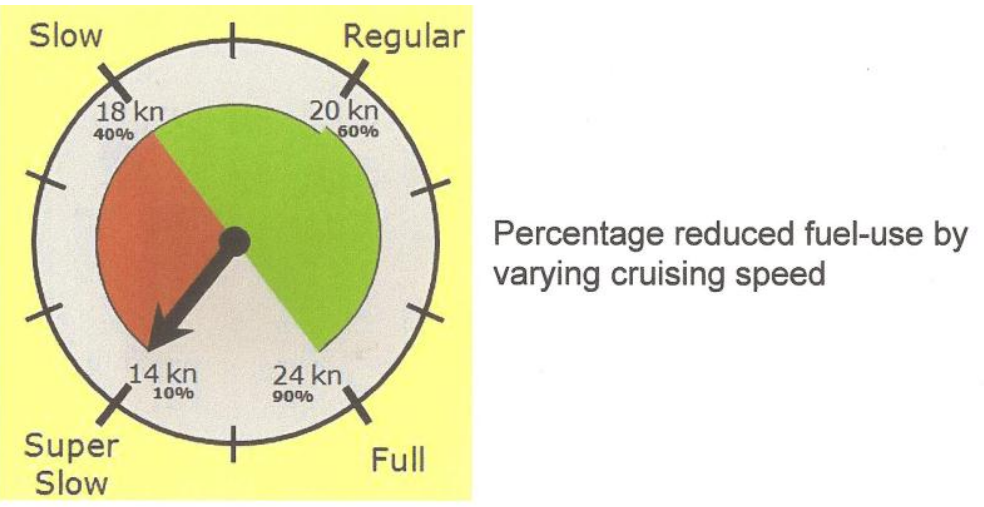

Figure 69 : Impact of the speed of the vessel to fuel consumption

( Source : Port of Antwerp (.2012))

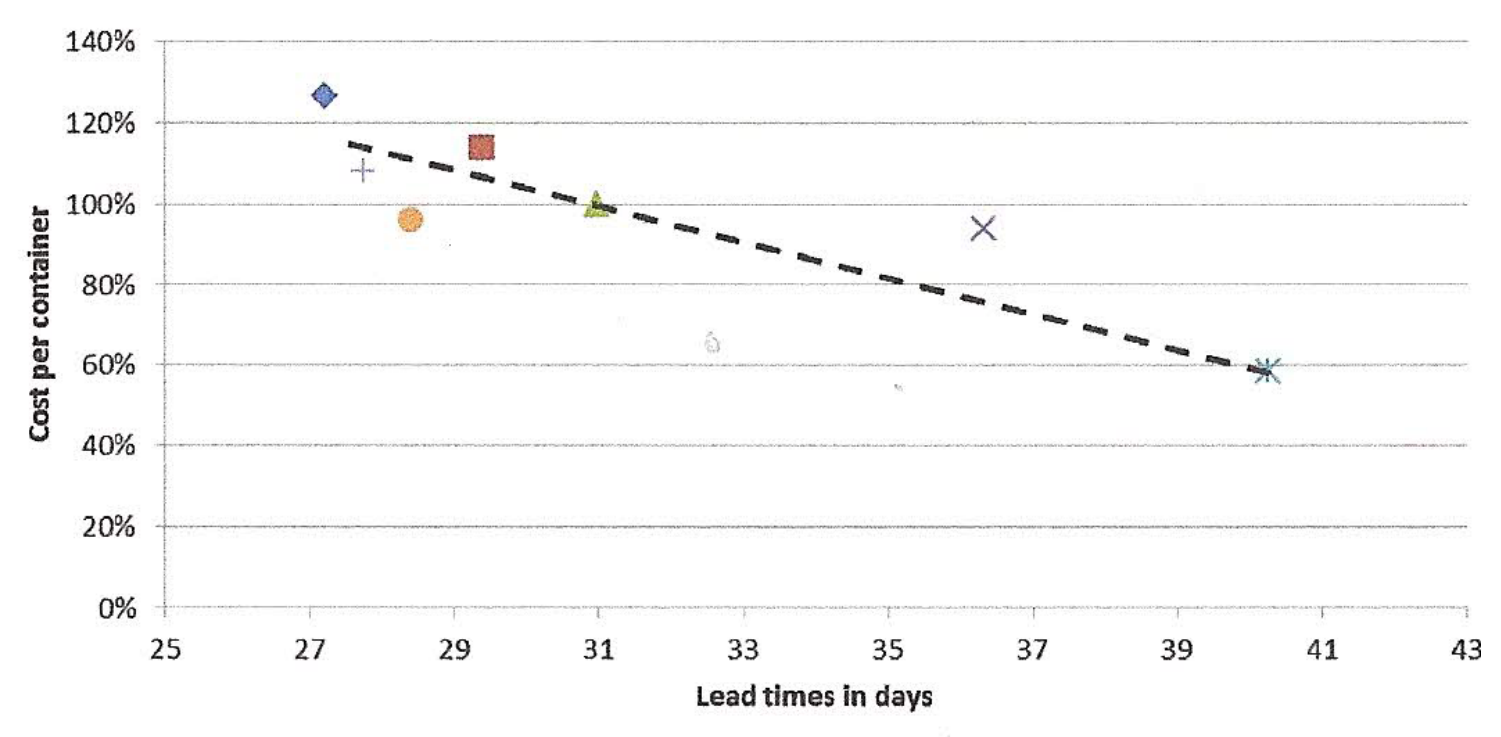

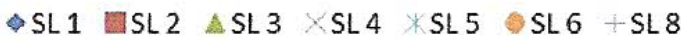

Figure 70 : Real Examples of the impact to transportation cost of a container /day by lowering the speed and increasing the load factor ( after F.A.van de Weijer, 2013 ) 


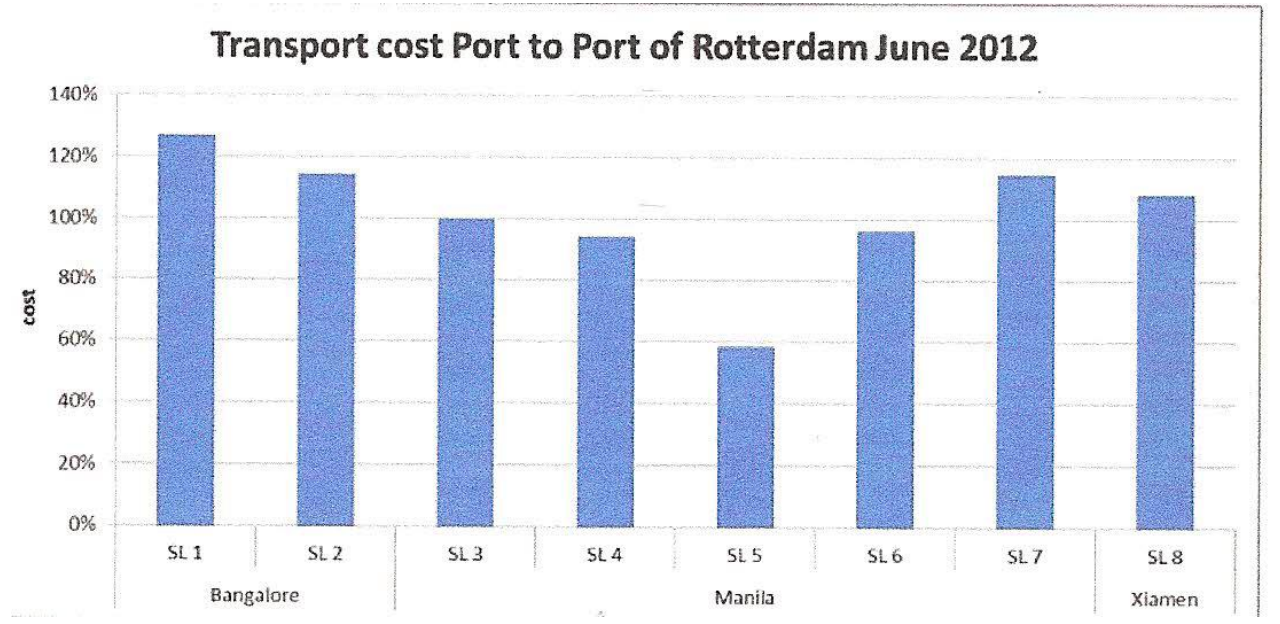

Figure 71 : Transport cost of different carriers 2012

( after F.A. van de Weijer, 2013 ).

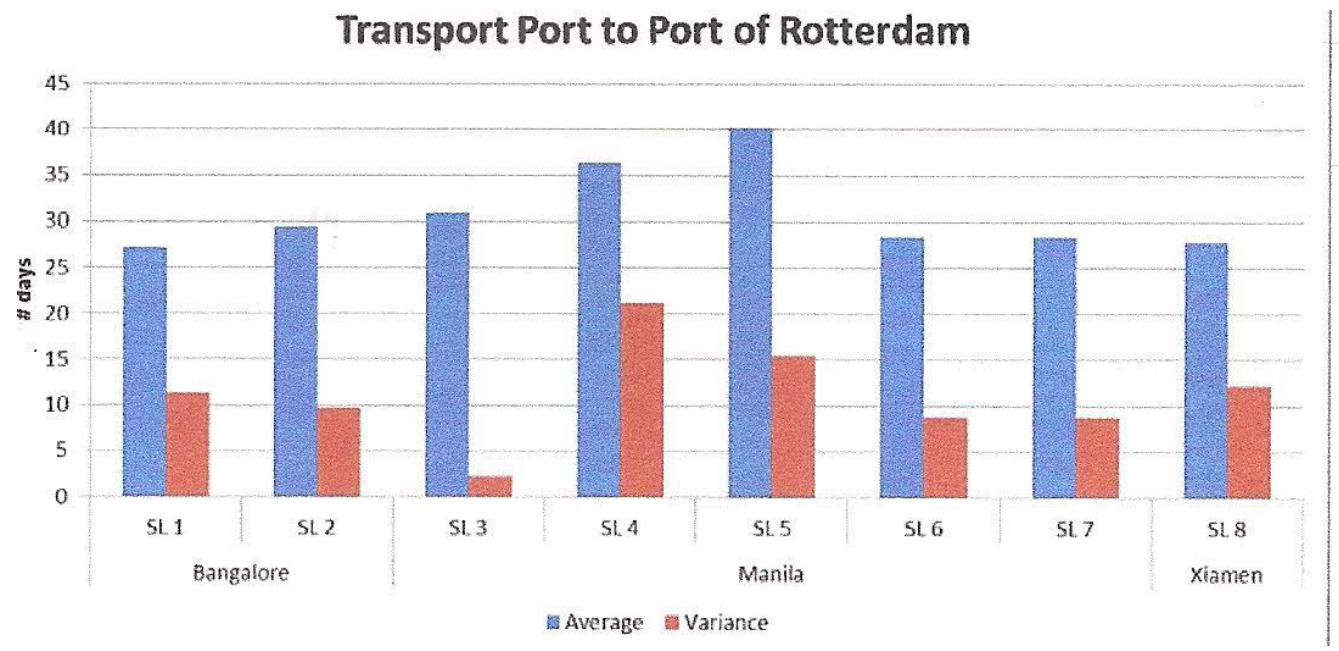

Figure 72 : Seafreight transport leadtime 2011

( after F.A.van de Weijer ).

Figure 71 and Figure 72 show the relation between cost and transportation time from port to port. Carrier SL6 needs 40 days, i.e. 10 days more than carrier 3 but was $42 \%$ cheaper. 
On the other hand, the customer has his products 10 days later on hand, which causes higher inventory cost and higher quality risks. F.A.van de Weijer has mentioned that the weighted average cost for transportation is about $4,4 \%$ of the total product cost, while the inventory holding cost are $8,5 \%$ of the product cost. From this view, it is a target to save time along the entire supply chain, if the process time in the harbor and in the Hinterland transport is reduced. Compared to todays average staytime of the containers in the yard the model shows that at least 3 days can be gained and the longer time of "cheaper" sea-transportation partly absorbed. With the mentioned relation each day in acceleration in the port allows costwise an extension of 2 days on the sea.

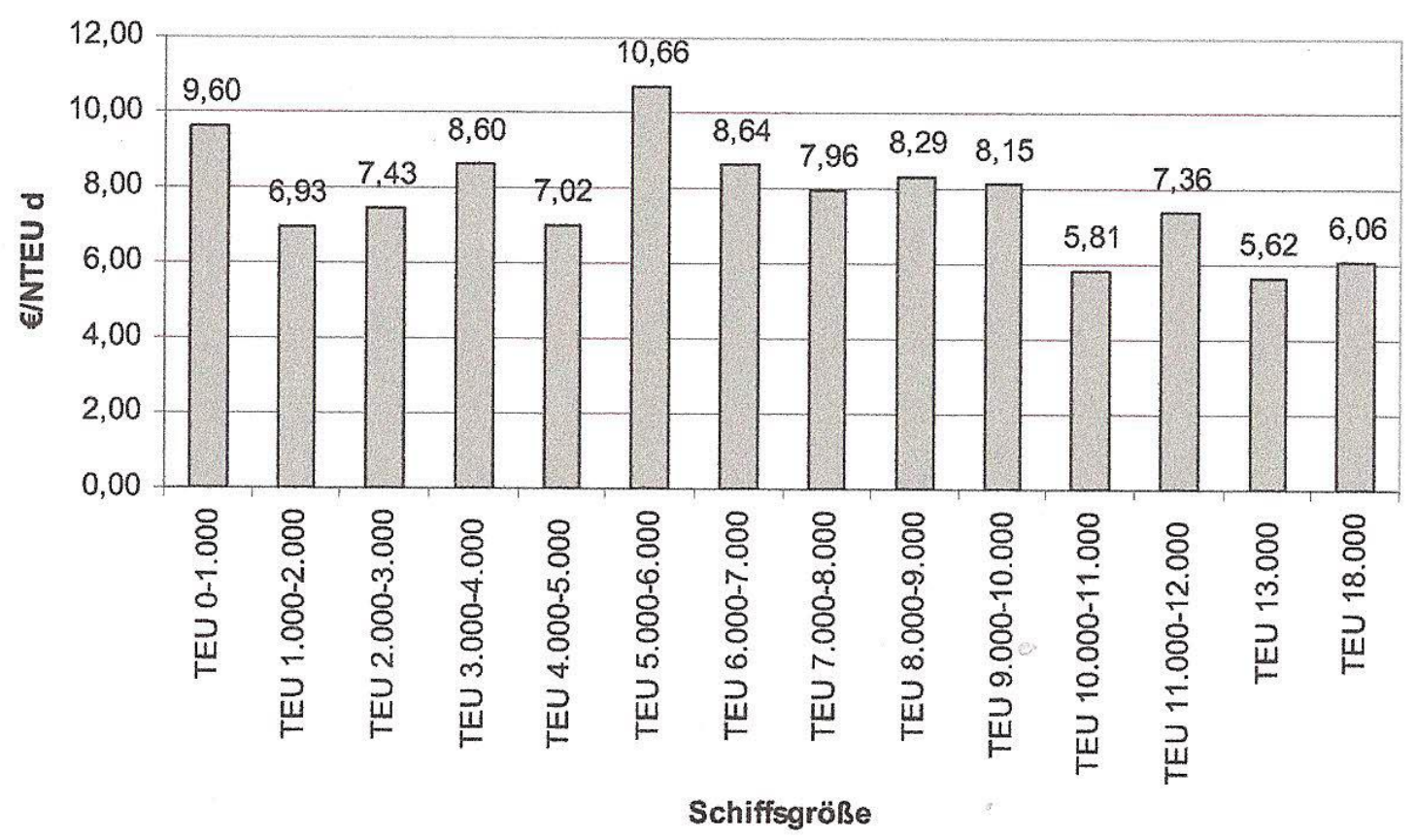

Figure 73 : Variable transportation cost (seaside) of 1 TEU/day for different ships. ( after A.Schönknecht (2006)) 
The variable seaside cost are in a range $10,66 €$ to 5,62 € per TEU and are mainly driven by the fuel consumption. Lower speed means lower variable cost. These cost are related to a Harpex Index in 2006, which was at this time at a value of around 1200. In 2013 the Harpex Index is down to $400-500$ so the prices to rent a vessel with the crew are today much lower. In the calculation is further the load factor and the part of empty containers to consider. Beside the seaside variable cost, the cost in the harbor for guiding, docking and parking has to be taken into account, as the amount of these variable cost is nearly as high as the seaside variable transportation cost. There is a potential of at least $50 \%$ in time reduction and cost saving. This means for the entire cost of the vessel, related transportation cost reduction of $10-15 \%$. This shows that it is worth to find solutions in the harbour to reduce the throughput time of the containers in the harbor and to increase productivity. However, as long the harbour companies have enough space in the yard, they have no interest in improving productivity and in reducing the throughput cost. A privatization of the ports may be a big help, because the shareholders will make pressure, to improve the competitiveness and to increase the profit. Anyway, this is a must for the harbors if they will handle the future growth with the limited resources in area. 


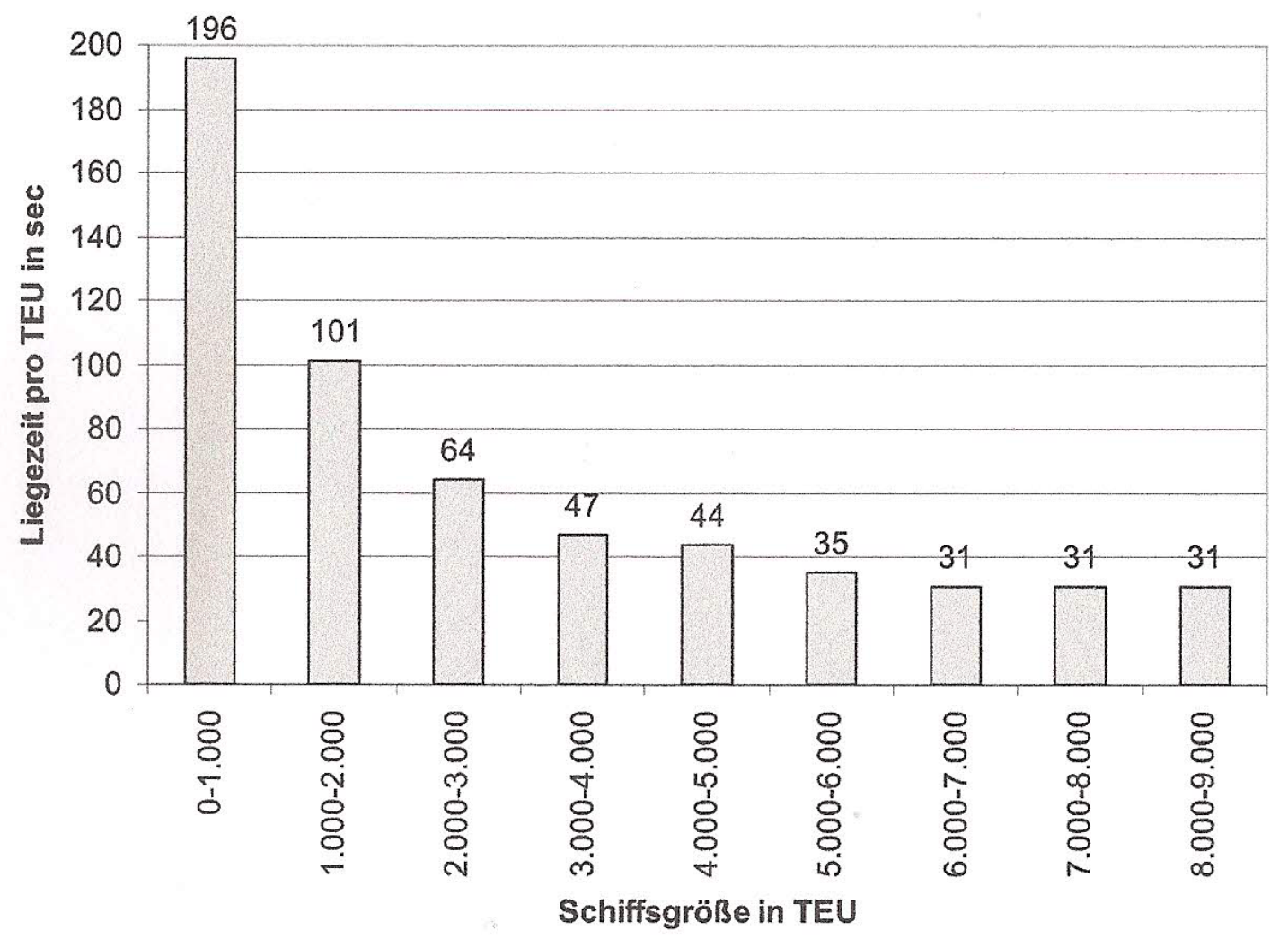

Figure 74 : The staytime of a vessel at the berth per TEU in seconds, depending on the vessel-seize ( after A.Schönknecht ( 2006 ))

The total staytime for the vessel with 9000 TEU is related to 5000 containers to be unloaded about 43 hours. Remark : the simulation shows only about 20 hours unloading and loading time. The smaller vessels have even a longer staytime and a much lower productivity. 
Table 10 : Cost of staytime in the harbor for 24 hours

\begin{tabular}{|l|c|c|c|c|c|c|c|}
\hline Schiffstyp & NTEU & $\begin{array}{c}\text { Länge in } \\
m\end{array}$ & $\begin{array}{c}\text { Tiefgan } \\
\text { gin } \mathrm{m}\end{array}$ & BRZ & $\begin{array}{c}\text { Raument- } \\
\text { gelte }\end{array}$ & $\begin{array}{c}\text { Lotse, } \\
\text { Fetmachen } \\
\text { etc. }\end{array}$ & $\begin{array}{c}\text { Hafengebühren } \\
\text { gesamt }\end{array}$ \\
\hline TEU 0-1.000 & 548 & 116 & 6 & 6.452 & $2.581 €$ & $3.847 €$ & $6.428 €$ \\
\hline TEU 1.000-2.000 & 1.400 & 169 & 7 & 17.315 & $6.926 €$ & $8.279 €$ & $15.204 €$ \\
\hline TEU 2.000-3.000 & 2.761 & 225 & 8 & 34.649 & $13.860 €$ & $10.887 €$ & $24.747 €$ \\
\hline TEU 3.000-4.000 & 3.322 & 251 & 9 & 39.698 & $15.879 €$ & $12.924 €$ & $28.804 €$ \\
\hline TEU 4.000-5.000 & 4.738 & 288 & 10 & 57.898 & $23.159 €$ & $15.194 €$ & $38.354 €$ \\
\hline TEU 5.000-6.000 & 5.473 & 292 & 11 & 70.552 & $28.221 €$ & $16.446 €$ & $44.667 €$ \\
\hline TEU 6.000-7.000 & 6.282 & 306 & 12 & 80.420 & $32.168 €$ & $17.414 €$ & $49.582 €$ \\
\hline TEU 7.000-8.000 & 7.245 & 330 & 13 & 89.717 & $35.887 €$ & $19.292 €$ & $55.178 €$ \\
\hline TEU 8.000-9.000 & 7.443 & 334 & 14 & 92.583 & $37.033 €$ & $20.798 €$ & $57.831 €$ \\
\hline TEU 9.000-10.000 & 7.783 & 346 & 15 & 103.498 & $41.399 €$ & $22.494 €$ & $63.893 €$ \\
\hline TEU 10.000-11.000 & 10.857 & 390 & 15 & 150.000 & $60.000 €$ & $23.375 €$ & $83.375 €$ \\
\hline TEU 11.000-12.000 & 11.214 & 400 & 15 & 142.418 & $56.967 €$ & $23.577 €$ & $80.544 €$ \\
\hline TEU 13.000 & 12.500 & 400 & 15 & 150.000 & $60.000 €$ & $23.577 €$ & $83.577 €$ \\
\hline TEU 18.000 & 17.343 & 400 & 15 & 239.380 & $95.752 €$ & $23.577 €$ & $119.329 €$ \\
\hline
\end{tabular}

The basic cost (Raumentgelte) are per TEU about 4-5 $€$ /day. For each 12 hours more than 24 hours, the cost increase is $50 \%$ of the basic cost. The other cost per TEU are decreasing with the seize of the ship. But this shows that a reduction in the overall unloading and loading time of the vessel has a big impact to the logistic cost. 


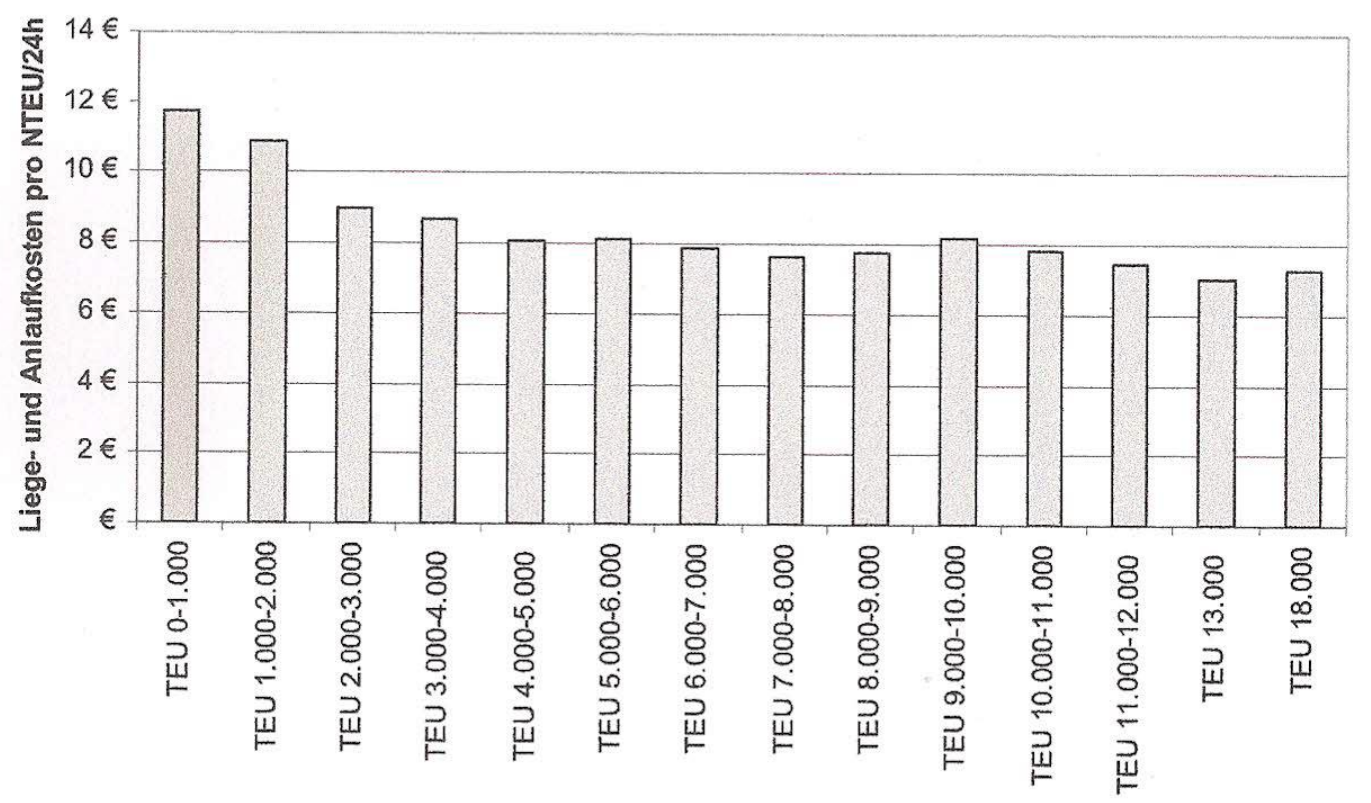

Figure 75 : Total landing and staycost in the harbor for 24 hours per TEU ( after A.Schönknecht ( 2006 ))

In comparison to the seaside transportation cost the harbor staytime cost are quite high. This potential cost savings can only be realized if there is a central coordination and organization to the entire supply chain. As long as the actors in the supply chain are only following their own interest and are optimizing their business, the final customer is paying for the lost opportunities. 


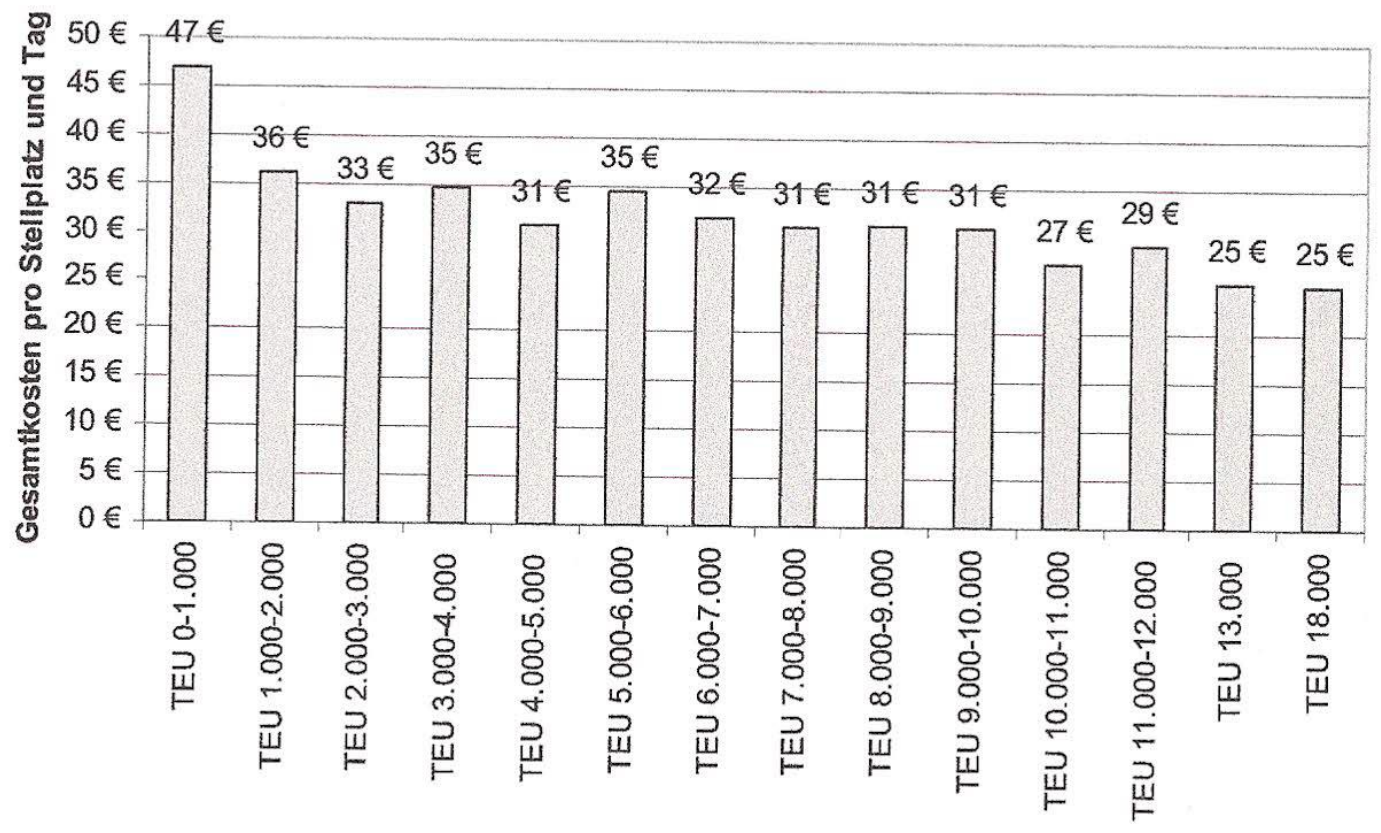

Figure 76 : Total cost per TEU and day ( seaside transport,harbor staytime) ( after A.Schönknecht ( 2006 ))

With a limitation of the unloading / loading time $<24$ hours these total costs can be reduced up to $10 \%$ of todays situation. The 'customer has the final benefit. 


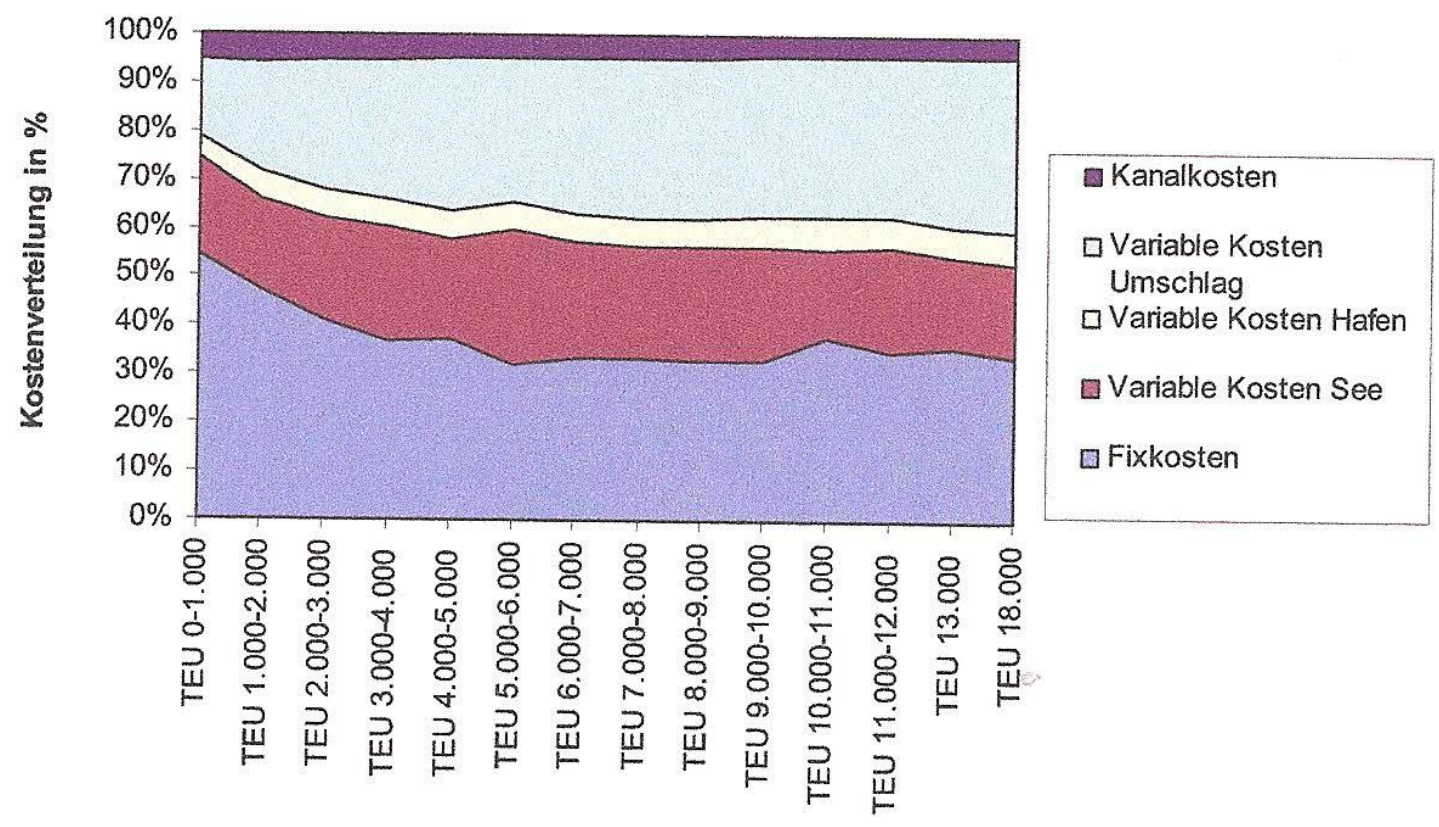

Figure 77 : Total distribution'cost for a transport from Asia through Suez -canal to the harbor Hamburg ( after A.Schönknecht ( 2006 ))

The distribution cost shows the big amount for handling cost in the harbor, which can reach up to $35 \%$ of the total seaside transportation cost from Asian harbour to Europe to the yard and the big potential, which can be gained. 
Table 11 : Terminal handling cost of different harbors ( after A.Schönknecht ( 2006 ))

\begin{tabular}{|c|c|c|}
\hline Hafen & $20^{\prime}$ Container & $40^{\prime}$ Container \\
\hline Antwerpen & $\$ 135,33$ & $\$ 135,33$ \\
\hline Bremerhaven & $\$ 184,71$ & $\$ 184,71$ \\
\hline Felixstowe & $\$ 125,08$ & $\$ 125,08$ \\
\hline Hamburg & $\$ 184,71$ & $\$ 184,71$ \\
\hline Le Havre & $\$ 149,51$ & $\$ 149,51$ \\
\hline Rotterdam & $\$ 166,69$ & $\$ 166,69$ \\
\hline Southampton & $\$ 125,08$ & $\$ 125,08$ \\
\hline Eastern PRC & $\$ 44,00$ & $\$ 66,00$ \\
\hline Hong Kong & $\$ 265,46$ & $\$ 353,51$ \\
\hline Japan main ports & $\$ 262,15$ & $\$ 377,08$ \\
\hline Kaoshiung & $\$ 165,98$ & $\$ 210,67$ \\
\hline Northern PRC & $\$ 44,00$ & $\$ 66,00$ \\
\hline Port Kelang & $\$ 88,11$ & $\$ 131,51$ \\
\hline Singapore & $\$ 108,93$ & $\$ 161,60$ \\
\hline Mittelwert & $\$ 146,41$ & $\$ 174,11$ \\
\hline \multirow[t]{2}{*}{ Kaitarif $(90 \%)$} & $\$ 131,77$ & $\$ 156,70$ \\
\hline & $109,81 €$ & $130,58 €$ \\
\hline
\end{tabular}

The staytime of the containers in the yard is depending on the processes for transportation to Hinterland. Harbors offering today a stay of 2 - 4 days free of charge. Then each additional day cost about $25 €$. The avg. stay of a container in the yard is between 3 and 4 days. Compared to the total seaside cost it is a big cost driver and more reason to transport containers immediatly out of the yard. Today each container in the yard has to be moved about 3,8 times in the stacking area until it is leaving the yard. This are high internal costs ( equipment and driver ), which can be avoided with the automatic transport to trains and satellites. Of course the transportation from the yard to the satellite (or train station) is not free of charge. The assumption is, that the cost are similar to train 
transportation, which is about $0,08 € /$ tonkilometer. The weight of 1 TEU container is in average 14 tons plus 2,6 tons tara, i.e. altogether 16,3 tons. The variable cost for $10 \mathrm{~km}$ to the satellite are 1,30€/TEU. This is much less than the yard stacking cost ( equipment and driver ). The transportation cost from trainstation / satellite to the final destination will not be deeper discussed. Todays truck costs are in a range of $0,09-0,13 €$ /tonkilometer. This may change in the future as laws, regulations and fuel cost will increase the overall transportation cost by truck. For a total supply chain cost an example is made for a total 600 kilometer Hinterlandtransport in comparison truck -train.:

- Truck : Transport to satellite $10 \mathrm{~km} 10 \times 0,13 € /$ tonkm) $=1,30 €$

$600 \mathrm{~km}$ truck ( 16,3 tons $\times$ 0,10€/tonkilometer $=1,63 € / \mathrm{TEU} / \mathrm{km})=978,00 €$

Total

$=979,30 €$

- Train : it cannot reach the final customer direct and needs a truck for the last 50 $\mathrm{km}$, transport to train station with $1 \mathrm{~km}$ is neglegtable

$550 \mathrm{~km}$ train $(0,08 € / \mathrm{tkm} \times 16,3$ tons $=1,30 € /$ TEU km $) \quad=715,00 €$

$50 \mathrm{~km}$ last mile by truck ( truck cost may be higher $0,15 € / \mathrm{tkm}=2,45 € /$ TEU $\mathrm{km}$ )

$=122,25 €$

Total

$=837,25 €$

The train transport to Hinterland combined wih truck is cheaper with growing distance. Until a distance of about 300 kilmeters the truck transport is under todays conditions cheaper than a train. To summarize the total cost along the supply chain, the total seaside cost are in a range of $15-22 € / \mathrm{TEU}$ and the landing and transportation cost to Hinterland 
are in a range of $980-1176 €$. This shows where to major potential for cost reduction must be researched. 


\subsection{ENVIRONMENTAL ANALYSIS. IMPACT TO EMISSIONS AND POLLUTIONS.}

In the Region EU 15 was the transportation sector for $25 \%$ of the total $\mathrm{CO}_{2}$ emission responsible, thereof $93 \%$ from the road transportation ( EMEP/EEA pollution handbook 2013 ). The OECD study 2010 stated that vessels are responsible for the global emission of :

- $\mathrm{CO}_{2}: 3-4 \%-$

- $\mathrm{NO}_{\mathrm{X}}: 10-15 \%$

- $\mathrm{SO}_{2}: 4-9 \%$

The IMO ( International Maritim Organisation ) estimates in a 2009 study based on 2007 values a $\mathrm{CO}_{2}$ pollution increase caused by the growth of the shipping industry of 150 $250 \%$ which is equal to 1400 million tons. As vessels have a lifetime of $25-30$ years and most of them are still powered with heavy oil ( high sulphur content ) it will take a long period to "clean" the engine combustion. If these ships come into harbors, they must run their engines for power supply. To reduce these emissions in harbor areas, a lot of harbors errect a landside electric power supply. Hamburg has errected several windmills in the harbour, to produce electricity. New regulations for $\mathrm{SO}_{\mathrm{x}}$ are coming globally in 2020 with a limit of $0,5 \% . \mathrm{NO}_{\mathrm{x}}$ tier III limits are valid for all ships built after 2016. 
Most harbors have already programs in place, to reduce the future emissions. Rotterdam had in 1990 a total emission of $\mathrm{CO}_{2}$ with 24 million tons. If they do not take any countermeasures, the pollution will double until 2025. With full actions, Port of Rotterdam will reach by 2025 a target of 16 million tons. They offer a bonus program esp. for the new port Maasvlakte 2, and ask their partner companies, to reduce truck traffic and to switch to feeders and trains. A similar bonus, based on ESI, which measures performance in pollution reduction, is offered in the port of Antwerp. They replace in the yard equipment Diesel engines by hydrogen generators and natural gas engines and reduce $\mathrm{CO}_{2}$ emissions by 240 tons a year. Quite famous is the Green Flag Speed Reduction Program of the Port of Long Beach. If the shippers are slowing down their speed and are reducing emissions, they get discounted fees. The program started in 2009. The ports of Los Angeles and of Long Beach have further started a Clean Truck Program, which means that they give only limited concessions to trucking companies, who fullfil certain criterias, such as meeting the 2007 US Environmental Protection Agency's Standard. It is a basic interest to reduce combustion engine use and replace them by electric driven vehicles. Truck transportation has a 4-6 times higher $\mathrm{CO}_{2}$ emission than trains. For a truck, carrying $2 \mathrm{TEU}$, the $\mathrm{CO}_{2}$ pollution is about $44-70$ gram/tonkilometer. A train produces about 7- 12 gram/tonkilometer. 


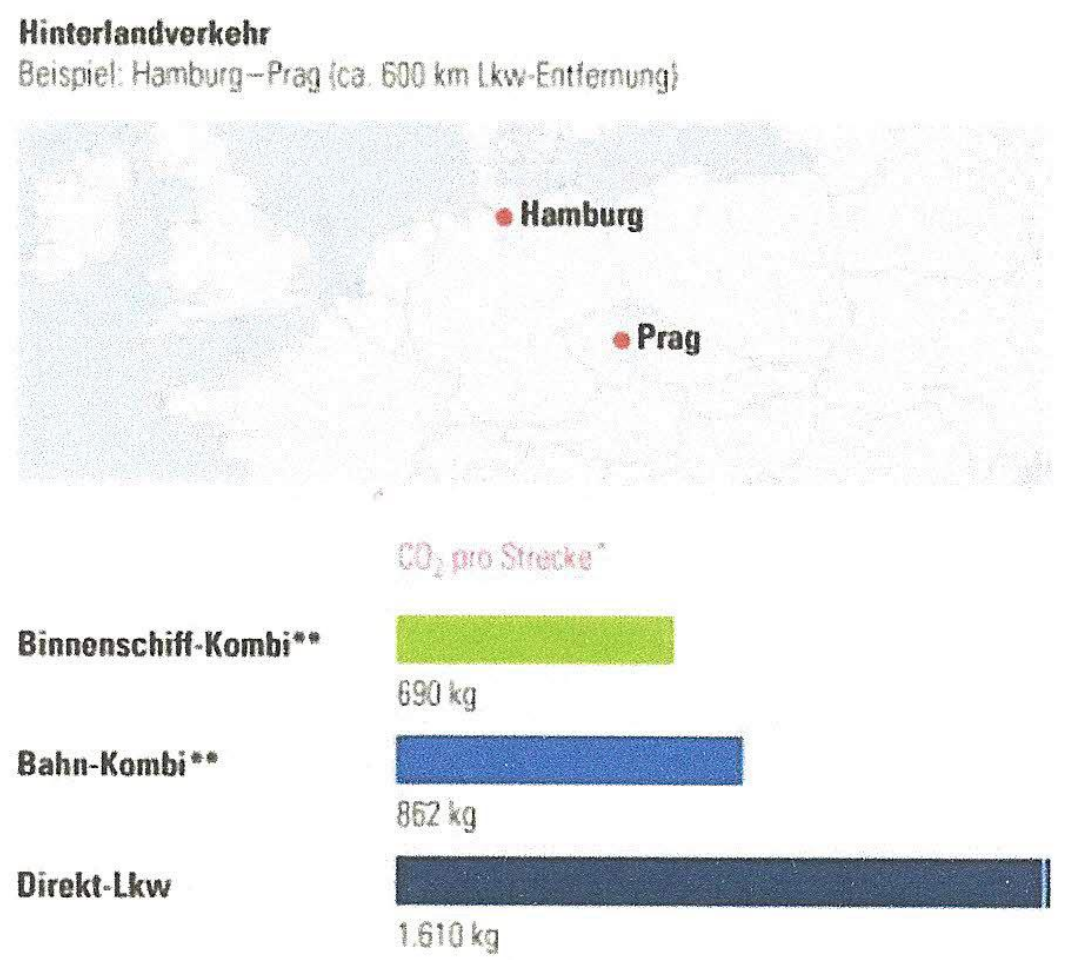

Figure 78 : Example for $\mathrm{CO}_{2}$ pollution for different transportation systems ( after Der Hafenentwicklungsplan bis 2025, Hamburg ( 2012 ))

The example shows that there is a high pressure, to shift modalsplit from trucks to feeders and to trains. Today the truck transportation is faster than train, but with better coordination, there is a lot of room for improvements. In the next figure there is the distribution of total costs without considering infrastructure cost. There is mentioned a column "External Cost". The content of these costs are traffic caused, such as air emission, climate change, infrastructure, noise, accidents and congestions. The values of variable costs seem with cost base 2013 to low. 


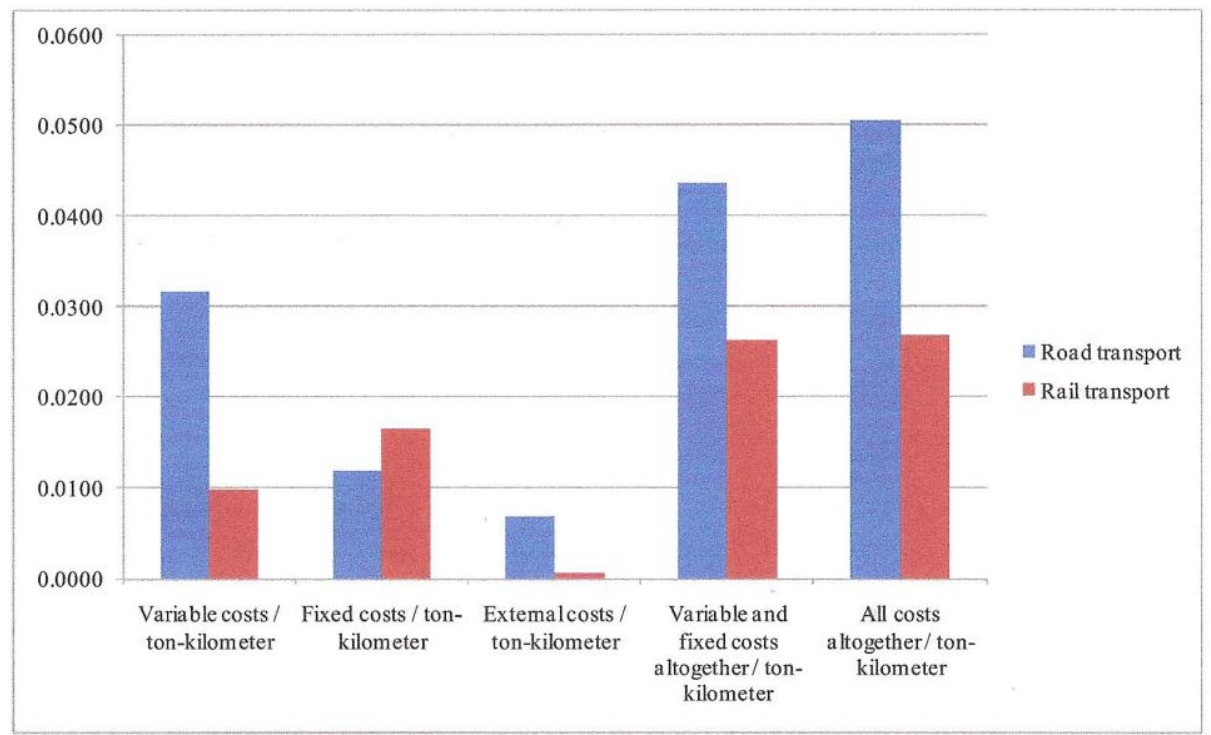

Figure 79 : Example of comparison between truck and train transportation cost in Finland ( after V.Henttu et al ( 2010$)$ )

A container vessel with a seize of 8000 TEU is consuming about 215 theavy oil a day, if its speed is $25 \mathrm{kn}$. With reduction of the speed to $16 \mathrm{kn}$ the consumption is roughly half. This means a reduction of 20 tons of $\mathrm{CO}_{2}$ /TEU. During staytime in the harbor the engine of the vessel still must be operated and needs at least 10 tons a day with an emission of 30 tons of $\mathrm{CO}_{2}$. With increase of the productivity, the service time of the ship could be reduced, as shown by the simulation, by 1 day and therefore avoided 30 tons $\mathrm{CO}_{2}$. To unload 5000 containers there are in a tradidional layout about $50 \mathrm{AGV}$ and $50 \mathrm{ALV}$ or / and Reachstackers necessary, to meet the result of the simulation model ( 20 hours). If they are powered with Diesel-engines and assumed they are consuming 15 liter each/hour then they are consuming together during the 20 hours 30000 liter Diesel, which causes a total emission of 78 tons of $\mathrm{CO}_{2}$ ( 1 liter Dieselburning produces 2,6 kilogram $\mathrm{CO}_{2}$ ). Then with todays layout these containers must be moved about 3-4 times in the yard 
stacker, until they leave the harbor area. Assumed each move takes 5 minutes, then about 3000 hours with the Diesel engines of the movement equipment are necessary. This creates an emmission of 58 tons $\mathrm{CO}_{2}$. If the loading process of the vessel will be done with the same procedure like the unloading process, another 78 tons of $\mathrm{CO}_{2}$ will be produced. With the satellite model and the modalsplit of $70 \%$ truck transportation to Hinterland, 7000 trucks will not come into the harbor and save together 105000 kilometer ( assumption that a truck which is picking up a container is not bringing a container in the same time and there is no waiting time and no congestion ). The effect is with the emission values of Figure 72 that 470 tons of $\mathrm{CO}_{2}$ will be avoided.

To summarize the reduction of emissions related to the loading and unloading of 10000 containers ( 5000 unloaded and 5000 loaded ) with the proposed layout in the simulation model there could be avoided for 1 ship ( the model includes 2 ships ) altogether 684 tons $\mathrm{CO}_{2}$ emission. Considering 2 ships a day and 240 working days, there can be avoided with the assumption of the model 328320 tons of $\mathrm{CO}_{2}$.

As a conclusion to the environmental impact of the proposed simulation model, there is a major progress in transporting the containers without any intermediate stacking direct out of the yard, distributing to satellites, trainstation and feeder collecting place. A future shift of the modal split from truck to train and feeder reduces emissions in addition dramatical. 
$\&+\$ 37(5 \square 0$

$6800 \$ 5<\square \& 21 \& / 86,216 \square \$ 1^{\prime}$ ' [5( \&200 ( $1^{\prime} \$ 7,216 \square$

The prognostics show, that the transportation with containers is a fast growing business, supported by the the growth of the world trade. The major hub harbors in the world are faced with a growth of 2-3 times of their actual volume of container handling within the next 20 years. In most cases there is limited space and they will be forced, to develop innovative solutions for more efficiency, faster throughput, more integrated logistic processes and less emission and pollution. The cost pressure to shippers demands a faster turnover time for the unloading and loading processes of their ships in the harbors. To match these targets a simulation model was developed, to allow cutting overall cycletime in handling and transporting containers around the harbor area. Learning from well approved logistic processes in the automotive industry, like just in time ( JIT ) and just in sequence (JIS ), the basic ideas for the model are, to eliminate intermediate stacking and multiple handling of the containers in the yard, to organize direct loading to trains and trucks, to have a continuous flow of the containers out of the harbor and into the harbor to trainstation and to satellites ( Dryports) in different directions and distances of 5-20 kilometers, to distribute traffic. With the datas of the BoL ( loading and unloading ) a link between the logistic processes from unloading to the 
final destination ( and reverse ) is fixed. The transportation of the containers to their intermediate destination shall happen automatically and with manless transportation units. Specific requirements, like customs clearing time for a certain percentage of the containers, or a shipping window of 8 hours to some customers are integrated in the model. For the trains two different types of train destinations are built ( long distance with a longer loading time and short distance trains for supply of different distribution centers ). All active elements and all process parameters in the model can be varied in the performance values. This flexibility allows to modify the model and to adapt the model to nearly any harbor situation in the world. For a given modalsplit to Hinterland ( $10 \%$ feeder, $20 \%$ train, $35 \%$ satellite 1 for trucks, $35 \%$ satellite for trucks ) a basic simulation model is designed. With this basic model it is shown, that two vessels, with 5000 containers each, can be unloaded and loaded in parallel processes within 20,11 and 20,44 hours, which is at least half of the time used today. It is further shown, that within 18,04 hours 40 trains, with 50 containers each, can be unloaded and loaded in parallel processes. The truck loading is split in two observations. First in a direct loading and second in the delayed loading, due to 8 hours quarantine and the shipping window between $8-16$ o'clock. The last truck is loaded after 31,99 hours. Beside these absolute timing, the through-put-times ( TPT ) can be determined for each container and a statistic can be made. The variance of the TPT let determine the bottlenecks and allows improvements and optimizations of certain processes or equipments. In the basic model, one bottleneck is the truck loading capacity, which slow down the flow in the transportation systems. The QCs are "producing " more containers than the loading capacity of trains and trucks can absorb. The transportation systems to trainstation and to 
satellite become rolling storages, what is acceptable under the overall view. The summary report show staytimes in each part of the system and let find bottlenecks. During the simulation run each active element can be surveyed with status monitors ( SM ). For the QCs is found a high utilization. The TC have an idle time between 25 and $34 \%$, which is to understand, as each train has a dead time of about 30 minutes for coming into the station and to leave the station. During this time the TC cannot serve this railtrack. Other SM show the load charge at different positions, like administration desks and allows to measure capacity charges. The SM at the truck docking station has a small idle time, which is mainly caused, that at the beginning of the simulation process, it takes about 18 minutes, until the first container can be loaded to the truck. The simulation shows overall, that the model works and produces reasonable results. Although there are some simplifications made, it is possible, to get indications for planning the integrated logistic chain and detect bottlenecks.

With changes of process parameter influences to major target values, like departure times ( ships, trucks and trains ), TPTs, and utilizations and possible optimizations can be realized. The optimization program of the simulation software is not applicable, due of the complexity and dependance of the amount of processes in the logistic chain. Therfore 13 modifications of the basic model are done, to learn about more optimal configurations. First a variation of the length of the $\mathrm{YCa}$ is done. An extension to $21500 \mathrm{~m}$ has a negative effect to departure times of the vessels and cost money. The reduction of the length by $2000 \mathrm{~m}$ has no effect to departure times and saves investments. Extension of the $\mathrm{YCa}$ and a double speed of all transportation system have as well a negative impact to the departure times and must be rejected. A lower constant speed for 
all transportation systems does not influence the results of the basic model and can be recommended, as the operating cost may be reduced. The increase of the capacities of the administration desks and the truck loading stations ( double ) reduce the TPT for the truck related containers significantly. The question is, what is the benefit, if there is peak business with idle capacities in this area afterwards. There is no need, as long as the truck loading terminal will not be served by other ( additional ) yard terminals. The departure times of the vessels is not affected. With a triple truck loading capacity there is no change to the model with double capacity. If there is only a direct loading of the trucks ( no shipping window and no quarantine ) the positive effect for TPT and for departure of the last truck is only visible, if there is a double truck loading capacity. Disturbances in the transportation systems causes a delay of the ship departures as well, if one crane or two cranes for ship 1 fail. The trains are in these cases as well delayed. These are critical processes, which influence the overall transfer timing. Then there are two different modalsplit modified with an increase of the train portion. As there are more trains necessary, the increase of the total loading time for the trains and the increase of the TPT is obvious. If the next vessel is coming soon after the ships have departed, there is an increase of the train infrastructure ( capacity $\mathrm{TCa}$, more railtracks, mote $\mathrm{TCs}$ ) to recommend.

The conclusion of the world trade growth during the next years and that more products will be shipped over the world, it is a must for more efficient harbors with new innovative logistic processes. Customization and make-to-order products require high flexibility and fast and reliable supply. This creates a challenge for the overall supply chain and for harbors. Space is limited, customers want their products as fast as possible 
on hand with lowest cost ( transportation and inventory ). In consequence the productivity has to be increased, the total throughput time to be minimized and waiting times to be eliminated. For fast and easy handling, the standardizised container logistic process chain has the best condition, to match these requirements. The automotive industry has shown with JIS and JIT, what big potential of time- and costsaving is possible to realize. Every kind of warehousing is waste (muda) and must be eliminated. Important is, to organize the entire supply chain and to eliminate single interests of the actors in the supply chain and to consider the overall economic advantage for the final customers of the product. An increasing importance is the environmental aspect of transportation. This is a dual fight. On one side to reduce todays emissions in order to match targets for climate control and on the other side to handle the big predicted growth of transportation, which causes more traffic on sea, on roads and on railways. The proposed model shows in the simulation, that a direct flow of the containers out of the yard and a direct shipping with trains and trucks without intermediate stacking can work and can give answers to to the challenge of growing volume. The advantage is, that the truck traffic can be kept out of the harbor area, the container streams can be divided in different directions for different main destinations, to the proposed satellites which can be Dryports. A parallel loading and unloading process of the containers is possible. The overall service time of vessels can be reduced significant and the staytime of the ships at the berth reduced, which allows lower cost and lower emissions. The automated transportation system in the yard and to trainstation, feeder collecting area and satellites avoid a lot of traffic of the yard carriers, with saving of manpower (drivers) and avoiding pollution. To keep the trucks out of the harbor reduces the traffic in and around the harbour with less congestions around the 
harbor and noise and pollution reduction. A $24 / 7$ service is easier to realize. The architecture of the simulation model allows a quick adaption to specific harbor conditions, like cycle time of equipment or modal split. Changes of process steps can easily be tested. Extension of transportation system, variation of speed, adding or reducing service stations are some examples to find capacity limits. Different numbers of containers, depending of the vessel seize, can be simulated by just changing the BoL. The model allows to simulate breakdowns of equipment and the consequences. Of course the real world is more complex. In the model is considered only one kind of container. In reality there is a split in $20 \mathrm{ft}, 40 \mathrm{ft}$, cooling containers, tank containes for liquids, which have to be separated. But this is not a problem, to modify the model and the processes. More important is a reliable BoL. In Table 12 there is shown a comparison of major differences between a traditional harbour and the model layout. 
Table 12 : Comparison of traditional harbors with the model

\begin{tabular}{|c|c|}
\hline traditional harbor & future model of a harbor ( with satellites / Dryports ) \\
\hline $\begin{array}{ll}- & \text { stacking and storing of containers in the yard } \\
- & \text { throughput-time of containers 3-4 days (avg) } \\
\text { - } & \text { multiple handling and stacking 3-4 times (avg) }\end{array}$ & $\begin{array}{l}\text { - no stacking or storing, immediate transporting } \\
\text { of the containers out of the yard to satellites, } \\
\text { Dryports, trainstation, feeder collection area } \\
\text { - } \quad \text { throughput-time hours (max.1 day) } \\
\text { - no multiple handling } \\
\text { - customers has his products much faster on } \\
\text { hand }\end{array}$ \\
\hline 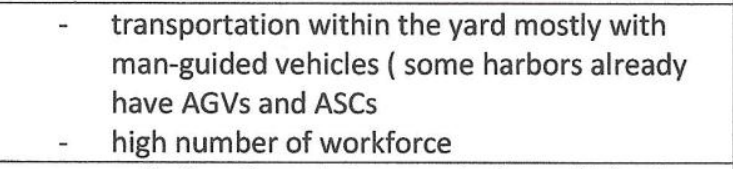 & $\begin{array}{ll}- & \text { automated transport systems } \\
\text { - } & \text { manpower mainly for equipment control }\end{array}$ \\
\hline $\begin{array}{l}\text { - pollution through transportation vehicles in } \\
\text { the yard }\end{array}$ & - $\quad$ no pollution in the yard \\
\hline $\begin{array}{ll}\text { - } & \text { yard area blocked by stacking and traffic } \\
\text { - } & \text { throughput volume limited to the space }\end{array}$ & $\begin{array}{l}\text { - yard area open for transport systems and } \\
\text { their infrastructure } \\
\text { - throughput volume limited to the speed of } \\
\text { the transport systems and the cycle time and } \\
\text { capacity of the QCs }\end{array}$ \\
\hline $\begin{array}{l}\text { - limited space for future growth of the } \\
\text { container logistics according to the } \\
\text { prognostics for the next } 20 \text { years } \\
\text { - } \quad \text { unsolved traffic problems with trucks }\end{array}$ & $\begin{array}{l}\text { - } \\
\text { fecentralization by satellites /DPs far away } \\
\text { area increase } \\
\text { - } \quad \text { traffic is distributed in different directions }\end{array}$ \\
\hline $\begin{array}{l}\text { - } \quad \text { high traffic in the yard by trucks transporting } \\
\text { containers from or into the yard } \\
\text { - } \quad \text { pollution caused by the trucks }\end{array}$ & $\begin{array}{ll}- & \text { no traffic in the yard } \\
\text { - } & \text { no pollution through trucks in the harbor }\end{array}$ \\
\hline $\begin{array}{l}\text { - } \quad \text { vessels need at least } 2 \text { days for unloading / } \\
\text { loading process } \\
\text { - } \quad \text { high berth cost and handling fee }\end{array}$ & $\begin{array}{l}\text { - vessels can be loaded and unloaded within } 1 \\
\text { day }\end{array}$ \\
\hline $\begin{array}{l}\text { - loading / unloading process of the vessels in } \\
\text { most cases not simultanious }\end{array}$ & - $\quad$ simultanious loading / unloading process \\
\hline $\begin{array}{l}\text { - logistic process is not planned as a entire } \\
\text { chain } \\
\text { - different actors in the different process steps } \\
\text { with different interests }\end{array}$ & $\begin{array}{l}\text { - logistic process is planned as an entire chain } \\
\text { with linked steps } \\
\text { coordination of all actors along the logistic } \\
\text { chain by cetral planning }\end{array}$ \\
\hline - a lot of processes without any added value & $\begin{array}{l}\text { - avoiding processes which do not create added } \\
\text { value }\end{array}$ \\
\hline
\end{tabular}

The major hurdle for realization satellites, Dryports and transportation systems to these places is probably the public approval process and the financing of the infrastructure. It should be in the public interest ( like building roads and bridges ) to 
make the state responsible for such solutions. Less traffic, less congestions, less pollution and and safe jobs by managing the growth are the benefits and will be a competition advantage. Another hurdle is the central organization of the entire logistic chain and to overcome the specific interests of the single actors in the chain. Therefore a neutral service organization is necessary, to handle all the confidential data of the high competitive transportation business. To reach a change of modalsplit from trucks to trains with less pollution, the state must make political constraints for trucks, like higher fees for roads, higher taxes to fuel and penalties for high emissions. On the other hand, more public investments for railway-sytems, in order to get a faster train transportation ( higher speed and higher frequency to major distribution centers ) and to reach more flexibility. The shippers should cooperate with the feeder transportation, to accelerate the throughput of the feeder related containers. In some harbors already joint ventures between shippers and / or harbor companies are founded. But feeders have still have to make a roundtrip to the harbour terminals and have 4-6 stops, which is time consuming. Layout concepts for feeders are still an open issue at most of the harbors. Another problem is, that the big shippers have their own containers with their brand. The exchange of containers is quite difficult. One argument is that the container design has different quality level and different robustness. If there would be a universal design, with neutral brand, like solutions in the automotive industry, a big potential of cost savings for empty container management can be realized. This is still an unsufficient field, waiting for deeper research. Based on the model, the future research should consider an optimized sequential loading of the vessel with constraints of the weight distribution, empty container management, a variation of container seizes and types and the workflow for defected 
containers. This should allow a further acceleration of the Hinterland logistics. This is important if the model is considering the reality with the different sizes and types of the containers. The unloading / loading process of these type differences will have an influence of the overall service times of the ship. While the differenzation between $20 \mathrm{ft}$ and $40 \mathrm{ft}$ containers can be reliable handled even with automated systems by camera recognition systems and a sequential loading of the vessel, i. e. sorting of compartments after container size, can be cooling containers, or containers with dangerous contents, or tank-containers a hurdle. There are limitations in loading areas on the vessel. The cycle time will be increased and a simultaneous unloading / loading is probably not possible because the containers to be loaded may not be cooling containers or may not have dangerous contents. The distribution with the YCa should not be a problem, but the distribution to satellites and to trainstation has to be reviewed. The TPT may be to long, as during transportation the cooling system cannot be operated easily. If the transportation system to the satellites is a tube system, it is unlikely to use this for such types of containers. A possible solution is either to make a separate exit on the TCa to store and handle it in a separate area in the yard, or to transport it with trains, where the cooling chain can be saved. These special containers are a challenge for the loading structure and sequence of the vessel. By creative planning the overall service time of the vessel should not be increased to much. The different sizes of the containers may be handled without increased cycletime if flexible grippers are used. But the problem will be to have the same structure available for the loading process of the vessel. For transportation with the proposed automated transport systems and the loading on trucks and trains it will be not a difference. To optimize the truck transportation a good planning 
is necessary that a truck can carry either one $40 \mathrm{ft}$ container or two 20 feet containers A deeper view should further done to a more continuous flow through the different transportation systems to find a equalization of the capacities in dependence of economic reasonable investments. The model considers one berth. The harbors have several berths, which should be integrated into the model, to get an entire workflow. For the expected increase of feeder transportation, there is a conceptual research and a simulation approach necessary. A practical open issue is the identification of the containers. RFID is worldwide not harmonized and have not a common language. Active RFID is to expensive and the service is not solved. Barcodes are not reliable enough. The identification is necessary for an automated distribution. There is still a lot to solve.

In the model there are made several simplifications. If the model will be applied for simulation of a real harbor system, a more detailed model with specific realistic solutions has to be designed. The first step would be to get a loading structure for the vessel, which considers the different types of the containers, their special handling and their destinations. This will allow a faster loading of trains and a better workflow in the transportation systems and a more detailed planning of the truck sequence. Assumed that all actors in the chain are supporting this model, basis data such as the overall volume of containers, the number of berths, infrastructure and distances to satellites, trainstation and feeder supply has to be fixed. Then the targets for service times for all loading / unloading equipment and the modalsplit has to be defined. If all these informations and assumptions are available and approved, a specific simulation model based on the principle model of this dissertation can be designed and developed within 300 hours. Such simulations can be a support for long-term harbor development. 


\section{5()$(5(1 \&(6$}

Agraval,Vijay (2010). Highly Productive Dense and Automated Container Handling Systems, Trend,PINC MMX Congress,Liverpool,Senior Port Planner,AECOM,Oakland,CA

Alba, D.(2012). The GRID project, Planet Forward, The George Washington University, Washington DC

Alicke,K. ( 2000 ). Modellierung und Optimierung von mehrstufigen Umschlagsystemen, Dissertation Universität Karlsruhe.

Arnold,D. Prof.Dr.-Ing, Rall ,B., Diplom Wirtschaftsing., ( 2006 ). A New Handling System for Freight Transshipment Centers in Comparison with other conception, University Karlsruhe

Bergqvist, Rickard. 2011), Rail Road Intermodal Terminals (Dry Ports) and necessary market conditions, Transbaltic report, region Skane, EU Baltic Sea Program

Bierwirth, C.and Meisel, F. (2010), A survey of berth allocation and quay crane scheduling problems in container terminals, European Journal of Operational Research, 202 (3), 615-627 
Biskup, Matti. (2010) Innovatives Konzept für Container-Terminal im SeehafenHinterlandverkehr, TU Berlin, Grin-Verlag München

Blung, Steffen. (2005), Modellierung und Optimierung von Hub-and-SpokeNetzen mit beschränkter Sortierkapazität, Disseration Universitätsverlag Karlsruhe

Bornhöft,N. et al ( 2011 ). Modeling of innovative technologies for container terminal yard stacking systems using an object-orientedsimulation framework. Proceedings of The International Workshop on Applied Modeling and Simulation,Rio de Janeiro.

Brinkmann, Birgitt. (2005). Seehäfen-Planung und Entwurf, Springer Verlag Berlin

Bruzzone, A et al.(2012). Simulation, analysis and optimization of container terminals processes, University of Genoa, Savona, Italy International Journal of Modeling Simulation and Scientific computing. ,Vol 3, No 4, p. 20

CargoCab GmbH, Bochum.( 2013 ). Homepage. www.cargocab.com.

Cullinane,K. Wilmsmeier, G. ( 2011 ). The contribution of the Dryport concept to the extension of Port Life Cycles. Transport Research Institute, Edinburgh Napier University, Edingburg 4/ UK 
Daduna, T.( 2012 ). Importance of Hinterland Transport Networks for Operational Efficiency in seaport Container Terminals, Faculty of Business and Economics, Berlin School of Economics and Law, Berlin

Dakosy ( 2012 )., Software-Lösungen für Transporte und Logistik,.

Datenkommunikations-Systeme, Hamburg Internal Presentation,

Dekker, S.et al.( 2011 ).Economically efficient port expansion/strategies: an optimal control approach, Transportation Mobility Division, Grontmij, Netherlands Transportation Research Part E47, p. 204-215

Deymann, Simon. (2011). Entwicklung eines Vorgehens zur Groblayoutplanung von Stückgutspeditionsanlagen, Dissertation TU Dortmund, Verlag Praxiswissen Dortmund

European Environment Agency ( EEA ).( 2013 ), EMEP/EEA air pollutant emission inventory guidebook 2013.

Farhanieh, S.( 2012 ). Toyota Europe's Freight Activity Outlook - 2030, TU Delft, Faculty of Technology, Policy and Management, Master Thesis, December 2012

Frost, James D.(2010). The „close“ Dry Port Concept and the Canadian Context, CPCS

Georgijevich, M et al.(2012). Adaptive control systems of Container cranes in river terminals ,University of Novi Sad, Serbia, Machine Design, Vol 4, p. 209-212 
Günthner, Willibald,A. (2007). Neue Wege der Automobillogistik, Springer Verlag Berlin

Hamburger Abendblatt ( 29.9.2012)

Harburger Anzeigen und Nachrichten. ( 17.3.2012 ).Kommen die Container unter die Erde?

Harper Petersen \& Co, ship brokers ( 2013 ), Hamburg, Harpex Index

Henttu et al, Ville. (2010). Financial and Enviromental Impacts of a Dryport to support two major Finnish transit seaports, Lappeenranta University of Technology, Research report 224

HPA. (2012 ). Hamburg hält Kurs-Hafenentwicklungsplan bis 2015

Iannone, F.( 2012 ). The private and social cost efficiency of port hinterland container distribution through a regional Logistics system, DIEM, Faculty of Econmics, University of Genoa, Italy, Transportation Research Part A46, p. $1424-1448$

IHK Nord. ( 2009 ).Die nationale Bedeutung der deutschen Seehäfen, Broschüre im Rahmen des Jahresthemas 2009 :Mobilität ist Zukunft 
ISL - Bremen.( 2010 ).Prognose des Umschlagpotenzials des Hamburger Hafens für die Jahre 2015, 2020 und 2025, Endbericht.

Jianxin Liu et al. ( 2013 ). Petri- net Modeling of Container-port work flow. College of Information Science and Eugineerily, Shandong University of Science and Technology Qingdao, China,Information Technology Journal 12 (9) 1845-1850, 2013-07-11

Jürgens, S. Et al. ( ). Data flow across the maritime value chain. Case study of an Integration of sea ports and Hinterland players. HHLA, Hamburg

Jürgens, S. Et al. ( ）. Data flow across the maritime value chain. Case study of an Integration of sea ports and Hinterland players. HHLA, Hamburg

Kap Hwan Kim, H-O Günther.(2005). Container Terminals and automated TransportSystems, Springer Verlag Berlin

Kap Hwan Kim et al.( 2012 ). New Conceptual Handling Systems in Container Terminals, Department of IE, Pusan National University Busan, Korea Industrial Engineering and Management Systems, Vol 11, No 4, December 2012, pp 299309 
Karafa ,J and Golias,M. (2012 ). Evaluation of intermodal marine container terminal gates via simulation, Dep.of Civil Engineering\&Intermodal Freight Transportation Institute,University of Memphis, $53^{\text {rd }}$ Anual Transportation Research Forum Tampa ,Florida, March 15-17

Klug, Florian. (2010). Logistikmanagement in der Automobilindustrie, Springer Verlag Heidelberg London

Köther, Reinhard.(2011). Taschenbuch der Logistik, Carl Hanser Verlag München

Kujath, Hans Joachim. (2003). Logistik und Raum-Neue regionale Netzwerke der Güterverteilung und Logistik, Working Paper nr.18, Leibniz Institut

Lam,J.S.L., Nottebohm,T. ( 2012 ). The green port toolbox : A comparison of port management tools used by leading ports in Asia and Europe ,IAME,Taipei

Madeira, A et al.(2012).Multicriteria and multivariate analysis of port performance Evaluation, Mechanical Department, Aeronautics Institute of Technology, Sao Paulo, Brazil,. Int.J. Production economics 140, p. 450-456

Manzano et.al.( 2009 ).Low-cost port competivness index: Implementation in the Spanish port system, University of Seville, Marine policy 33, p. 591-598

Maribus eGmbH, Hamburg. ( 2010 ). Das Meer - der weltumspannende Transportweg. World Ocean Review 
Meyer,Mohaddes Associates Inc. ( 2001 ). Ports of Long Beach/Los Angeles

Transportation Study, submittet to the port of Long Beach and the Port of Los Angeles

Moeller, D.et al.(2012 ). A simulation based decision making approach developingDryports, MIN Faculty, University of Hamburg, Peer Reviewed Paper presented at AlaSim

Muraviev, D.S., Rkahmangulov A.N ( 2011 ).Choice of “Dry”" Ports Basic Parameters Calculation Method, Magnitogorsk State technical University u.a.G.I.Nosov, Modern Scientific Research and their practical application. Vol 11308

Paceco Corp. ( 2013 ). Company information.

Parsons,Irvine,Ca. (2006 ). San Pedro Bay Ports Rail Study Update,prepared to the Port of Long Beach and the Port of Los Angeles

Port of Antwerp. ( 2012 ). Sustainableport\&logistic chain development, IAPH Mid-termConference.

Port of Long Beach. (2012 ). On track of Tomorrow, Brochure, Rail Guide.

Port of Rotterdam. ( 2011 ).Working together towards world-class

Private informations of the Port of Tauranga ,New Zealand,2012. 
Private informations from ZPMC, Shanghai,China,2012

Rodrigue,J-P.Nottebohm,T. (2012). Port regionalization : improving port competitiveness by reaching beyond the port perimeter, Port Technology International Edition 52

Rodrigue,J-P. ( 2006 ). Intermodal Transportation and Integrated Transport Systems : Spaces, Networks and Flows, Flowpolis:The form of nodal space conference,Las Palmas.

Roso, Violeta. (2009). The Dry Port concept, Thesis for PhD, Chalmers University of Thechnology, Göteborg

Roso, Violeta. (2008). Emergance and Significance of Dry Ports, Chalmers University of Technology Sweden

Roso, Violeta. (2008). Factors influencing implementation of a dry port, Chalmers University to technology Göteborg, Emerald Internationl Journal of Physical Distribution \& Logistic Management Vol.38 no.10

Schönknecht, A.( 2007 ). Entwicklung eines Modells zur Kosten - und Leistungsbewertung von Containerschiffen in Intermodalen Transportketten, Dissertation TU Hamburg-Harburg 
The Tioga Group. ( 2008 ). Inland Port Feasability Study,Project No.06-023, prepared For Southern California Association Governments

Tian Y et.al.( 2012 ).Study on equipments scheduling of ZPMC automated container terminal based on improved PSO,. Applied Mechanics and Materials 143/144, $879-884$

Tongzon J, Heng Wu.( 2005 ). Port privatization efficiency and competitivness: Some empirical evidence from Container ports. Dep.of Economics, National University of Singapore, Transportation Research Part A 39, p. 405-424

Trainaviciute, Lina. (2011). The Dry -Port Concept and Perspectives, StratMoS WP C, Report of FDT-Association of Danish Transport and Logistic Centres Aalborg

UNCTAD. (.1991.). Handbook on the Management and Operation of Dry Ports, Geneva

Universität Bremen. (.2010). The Governance of Dryport Integration-case studies on the implementation and operation of Dryports, presentation

Usabiaga,J.J. et al. ( 2013 ). A Simulation Model for Road and Maritime Environmental Performance Assessment, Journal of Environmental Protection,4,683 - 693.

VDI-N. ( 19.7.2013 ). Crossrail unterwühlt Londons Zentrum. 
Vaziri,A A,Khoshnevis,B. Automated technologies in maritimecontainer terminals. www.metrans.org/nuf/documents

Verdonek, L et.al. ( 2012 ). Analysis of the operations of an intermodal Barge Terminal IMOB, Hasselt University, Diepenbeek, Belgium

$\mathrm{Wu}, \mathrm{Y}$ et al. ( 2010 ). Container port efficiency in emerging and more advanced markets Dep. of business management, National Sun Yat-Sen University, Taiwan Transportation Research Part E 46, p.1030 - 1042

Yuen, C et.al. ( 2012 ). Port competitivness from the users perspective: An analysis of major container ports in China and its neighboring countries, University of Hongkong, Research in Transportation Economics 35 ,p.34-40 


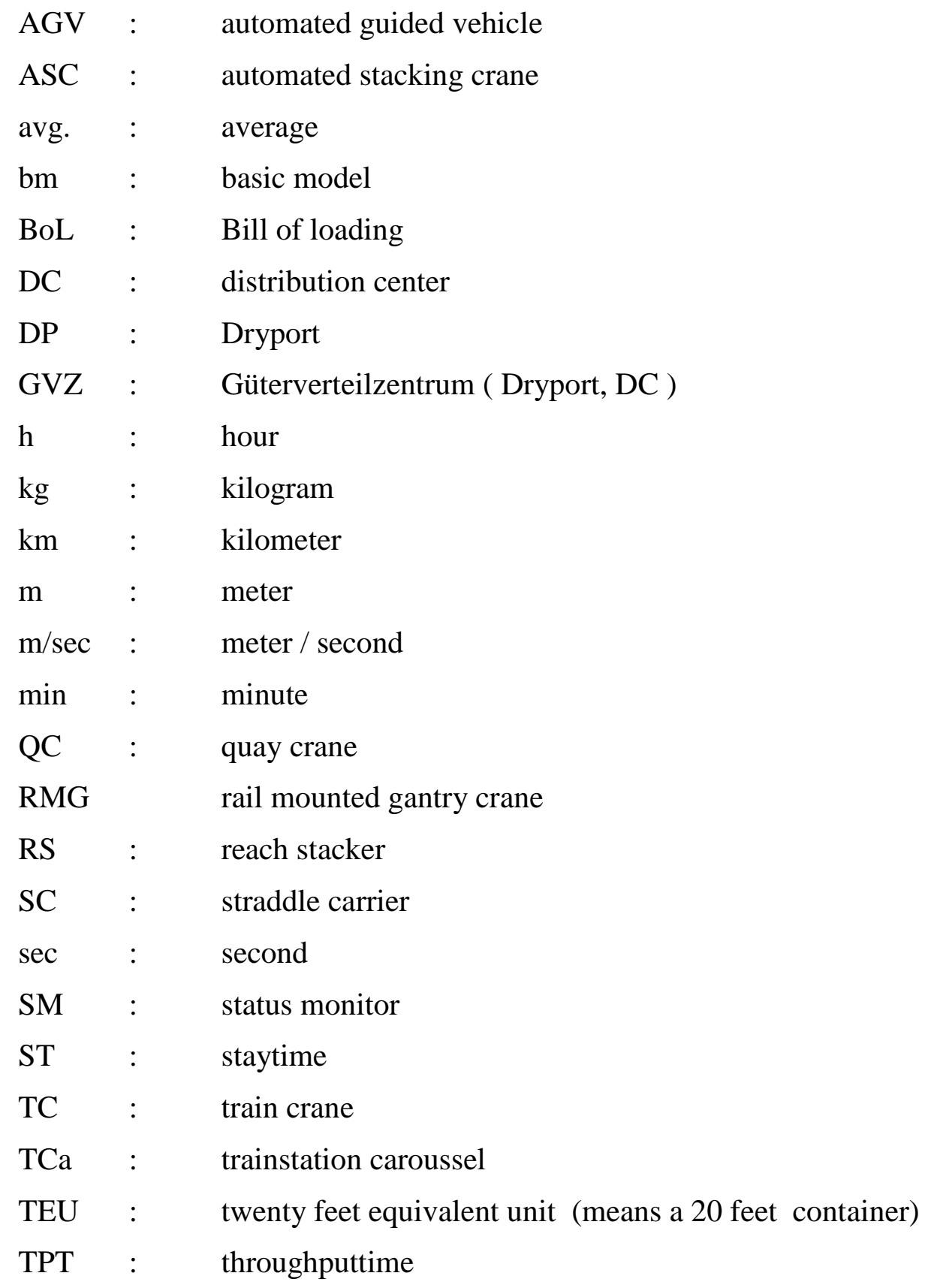


7 Name Klaus Striegel

(

Address

Kirchdorferstrasse 220

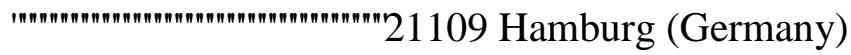

(

DOB Poppenweiler/Germany - August 27,1950

(

Marital Status married since 1990,no children

7

Education University Stuttgart (1970-1977)

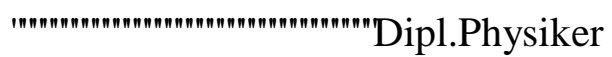

Verwaltungsakademie Stuttgart ( 1982-1985)

Betriebswirt (VWA)

University of Louisville (UofL),Louisville,KY (since 2009 )

German $\mathrm{PhD}$ program Industrial Engineering

Professional Robert Bosch GmbH ( 1977 -1989)

Carrier

R\&D,Product Manager,Program Manager

Südrad Autoräder GmbH (1989- 1993 )

Managing Director

Sudrad Roues France (1990-1993)

President Directeur Generale

Helphos GmbH,Solvay Automotive GmbH (1993-1999)

General Manager

Porsche AG, Cartopsystems GmbH,Magna Intern.Inc,( 1999-2008)

General Manager of Cartopsystems (daughter company of Porsche)

Porsche AG (2008 -2010)

Project Manager VL Boxster

ICS (since 2010)

Owner 